\title{
SENSITIVITY OF STORMWATER MANAGEMENT SOLUTIONS TO SPATIAL SCALE
}

\author{
A Thesis \\ presented to \\ the Faculty of California Polytechnic State University, \\ San Luis Obispo
}

\author{
In Partial Fulfillment \\ of the Requirements for the Degree \\ Master of Science in Civil and Environmental Engineering \\ by \\ Jeffrey Michael Barich
}

June 2014 
(C)2014

Jeffrey Michael Barich

ALL RIGHTS RESERVED 


\section{COMMITTEE MEMBERSHIP}

TITLE:

AUTHOR:

DATE SUBMITTED:

COMMITTEE CHAIR:

COMMITTEE MEMBER:

COMMITTEE MEMBER:
Sensitivity of Stormwater Management Solutions to Spatial Scale

Jeffrey Michael Barich

June 2014

Misgana Muleta, Ph.D., P.E.

Associate Professor of Civil Engineering

Kurt Chien-Kuo Lo, Ph.D, P.E.

Associate Professor of Civil Engineering

Christopher Surfleet, Ph.D.

Associate Professor of Natural Resources 


\author{
ABSTRACT \\ Sensitivity of Stormwater Management Solutions to Spatial Scale \\ Jeffrey Michael Barich
}

Urbanization has considerably altered natural hydrology of urban watersheds by increasing runoff volume, producing higher and faster peak flows, and reducing water quality. Efforts to minimize or avoid these impacts, for example by implementing low impact development (LID) practices, are gaining momentum. Designing effective and economical stormwater management practices at a watershed scale is challenging; LIDs are commonly designed at site scales, considering local hydrologic conditions (i.e., one LID at a time). A number of empirical studies have documented hydrologic and water quality improvements achieved by LIDs. However, watershed scale effectiveness of LIDs has not been well studied. Considering cost, effort, and practicality, computer modeling is the only viable approach to assess LID performance at a watershed scale. As such, the United States Environmental Protection Agency's Stormwater Management Model (SWMM) was selected for this study. It is well recognized that model predictions are plagued by uncertainties that arise from the lack of quality data and inadequacy of the model to accurately simulate the watershed. To scrutinize sensitivity of prediction accuracies to spatial resolution, four SWMM models of different spatial detail were developed for the Ballona Creek watershed, a highly urbanized watershed in the Los Angeles Basin, as a case study. Detailed uncertainty analyses were carried out for each model to quantify their prediction uncertainties and to examine if a detailed model improves prediction accuracy. Results show that there is a limit to the prediction accuracy achieved by using detailed models. Three of the four models (i.e., all but the least detailed model) produced comparable prediction accuracy. This implies that devoting substantial resources on collecting very detailed data and building fine resolution watershed models may not be necessary, as models of moderate detail could suffice. If confirmed using other urban watersheds, this result could benefit stormwater managers and modelers. All four SWMM models were then used to evaluate hydrologic effectiveness of implementing bioretention cells at a watershed scale. Event based analyses, 1-year, 2-year, 5-year and 10-year storms of 24-hours were considered, as well as data from October 2005 to March 2010 for a continuous simulation. The runoff volume reductions achieved by implementing bioretention cells were not substantial for the event storms. For the continuous simulation analysis, however, about twenty percent reductions in runoff volume were predicted. These results are in-line with previous studies that have reported ineffectiveness of LIDs to reduce runoff volume and peak for less frequent but high intensity storm events.

Keywords: Uncertainty analysis, Urban watershed modeling, Stormwater management, Spatial aggregation scale, Low Impact Development. 


\section{ACKNOWLEDGMENTS}

I would like to thank my advisor, Dr. Misgana Muleta, and the rest of my committee, Dr. Chin-Kuo Lo and Dr. Christopher Surfleet.

I would like to thank the Cal Poly Graduate Education Department for helping fund this research.

Thank you to my family, especially my grandma Janet Austin, my mom Karen Barich, my dad John Barich, and my sister Angela Barich, for their consistent support during my time at school.

Thank you to my classmates who helped me out along the way, specifically Scott Brake, Jennifer Shedden, Ashley Beschell, Hugo Velasquez, Jasper Jacobs, and Max Bigras. 


\section{TABLE OF CONTENTS}

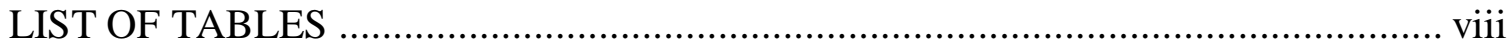

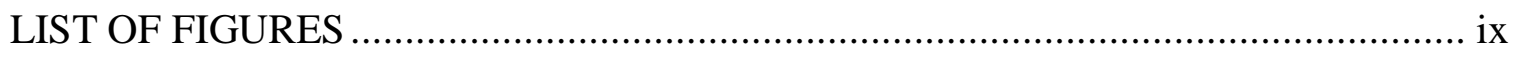

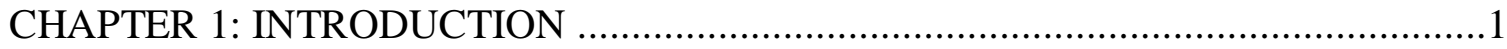

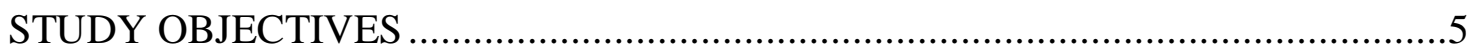

PREVIOUS WORK ...................................................................................

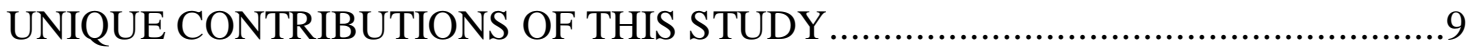

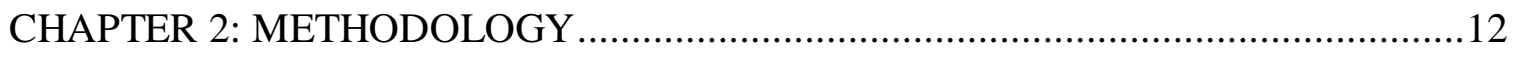

BALLONA CREEK WATERSHED ............................................................ 13

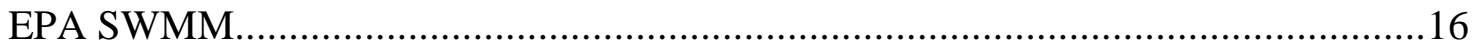

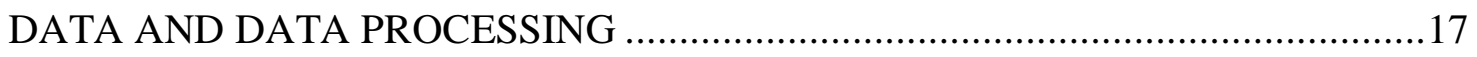

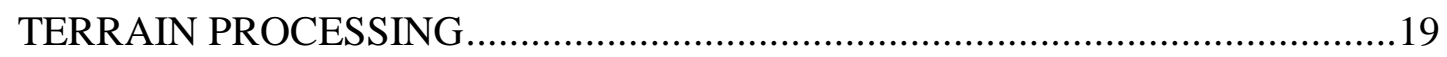

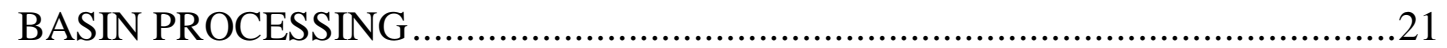

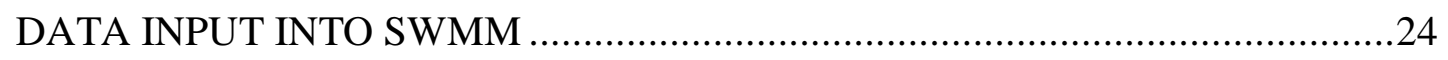

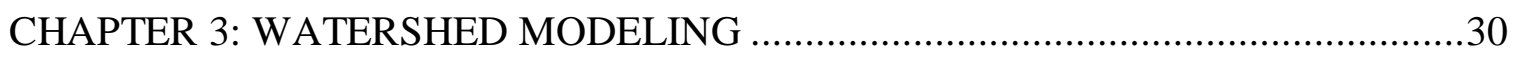

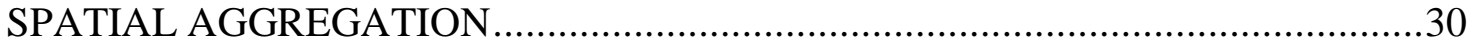

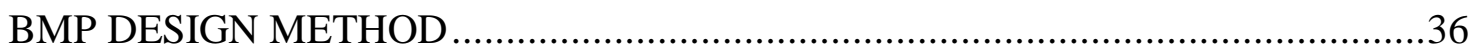

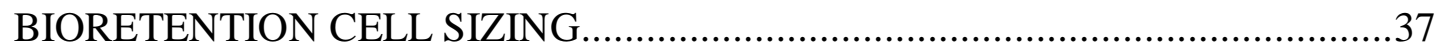

BIORETENTION CELL IMPLEMENTATION ............................................41

MODEL CALIBRATION EFFICIENCY CRITERIUM ........................................42

CHAPTER 4: CALIBRATION AND VALIDATION RESULTS AND DISCUSSION.47

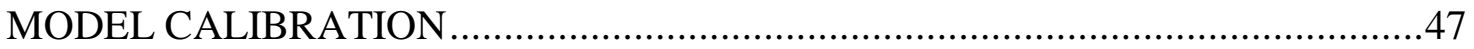

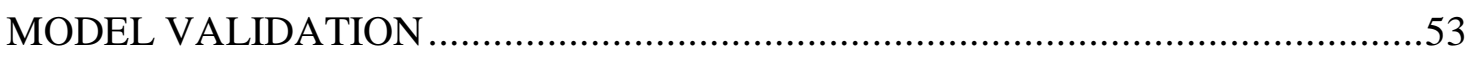

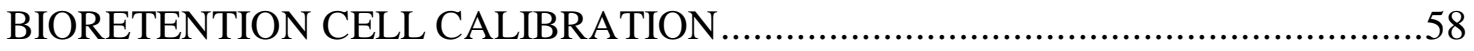

CHAPTER 5: UNCERTAINTY ANALYSIS RESULTS AND DISCUSSION.............61

CHAPTER 6: LID IMPLEMENTATION RESULTS AND DISCUSSION .................71

CHAPTER 7: CONCLUSIONS AND RECOMMENDATIONS ..............................79

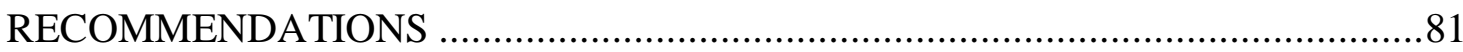

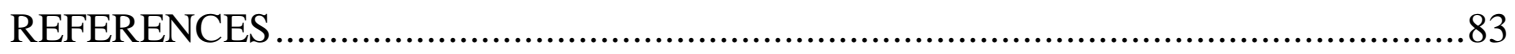




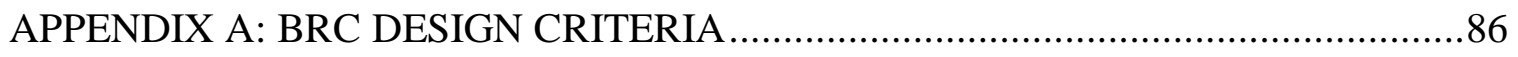

APPENDIX B: CALIBRATION AND VALIDATION RESULTS ..........................87

APPENDIX C: UNCERTAINTY ANALYSIS RESULTS .....................................95

APPENDIX D: LID IMPLEMENTATION RESULTS ......................................... 113 


\section{LIST OF TABLES}

Table 1: Curve Number Table...............................................................................22

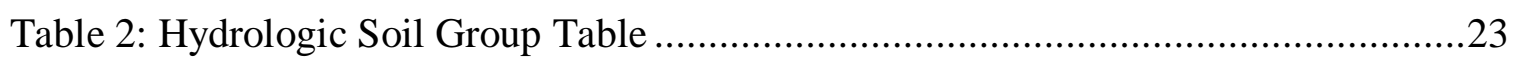

Table 3: SWMM Data Input Table..........................................................................26

Table 4: Stream Definition Threshold Table .............................................................. 31

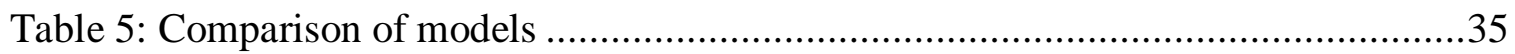

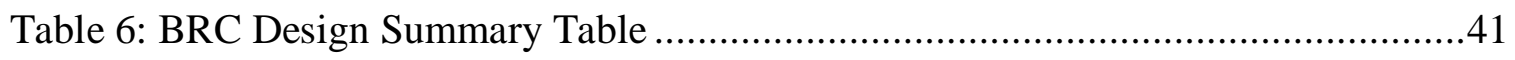

Table 7: Calibration efficiency value results ......................................................... 47

Table 8: Calibration modification percentages ...........................................................48

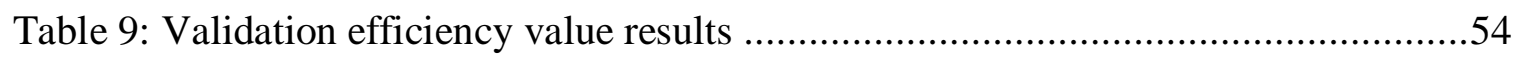

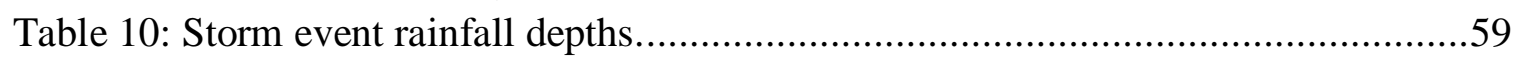

Table 11: Comparison of Observed and Modeled BRC Performances..........................60

Table 12: Uncertainty Analysis Reliability / Sharpness. ............................................62

Table 13: BRC Performance for 78-Subcatchment model. .........................................76

Table 14: BRC Performance for 244-Subcatchment model. .........................................76

Table 15: BRC Performance for 738-Subcatchment model. .........................................77

Table 16: BRC Performance for 1414-Subcatchment model. .......................................77

Table 17: BRC Performance for a single subcatchment (Subcatchment 1708 from the 1414-Subcatchment model)...............................................................78

Table 18: BRC Performance for a single subcatchment (Subcatchment 1519 from the

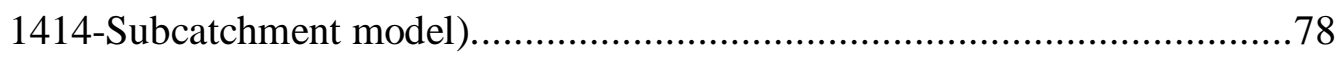

Table 19: BRC Design criteria chart (City of Los Angeles, 2011) ..............................86 


\section{LIST OF FIGURES}

Figure 1: Illustration of the effects of urbanization on stormwater runoff

(USDA Natural Resources Conservation Service, 2010)..............................1

Figure 2: Location map of Ballona Creek watershed (Muleta, McMillan, Amenu, \&

Burian, 2013). ................................................................................ 12

Figure 3: Ballona Creek, a 9-mile long flood control channel in Los Angeles County

(County of Los Angeles, 2013).............................................................13

Figure 4: Hydrologic Soil Group assumptions (United States Department of

Agriculture (USDA), 1986)............................................................23

Figure 5: Location of Hollywood312 rain gage (Google, 2014) .................................25

Figure 6: Location of Swattle370 rain gage (Google, 2014). ......................................25

Figure 7: Location of USC375 rain gage (Google, 2014). ........................................26

Figure 8: 78-Subcatchhment model, subcatchment delineations. ..................................32

Figure 9: 244-Subcatchment model, subcatchment delineations. ..................................33

Figure 10: 738-Subcatchment model, subcatchment delineations. ..............................34

Figure 11: 1414-Subcatchment model, subcatchment delineations. .............................35

Figure 12: 78-Subcatchment model, calibration time series, zoomed-in. .....................49

Figure 13: 244-Subcatchment model, calibration time series, zoomed-in. ....................50

Figure 14: 738-Subcatchment model, calibration time series, zoomed-in. ....................50

Figure 15: 1414-Subcatchment model, calibration time series, zoomed-in. ...................51

Figure 16: 78-Subcatchment model, calibration scatter plot. .....................................51

Figure 17: 244-Subcatchment model, calibration scatter plot. ..................................52

Figure 18: 738-Subcatchment model, calibration scatter plot. ..................................52

Figure 19: 1414-Subcatchment model, calibration scatter plot. ................................53

Figure 20: 78-Subcatchment model, validation time series, zoomed-in. .......................54

Figure 21: 244-Subcatchment model, validation time series, zoomed-in. .....................55

Figure 22: 738-Subcatchment model, validation time series, zoomed-in. .....................55

Figure 23: 1414-Subcatchment model, validation time series, zoomed-in.....................56

Figure 24: 78-Subcatchment model, validation scatter plot. ....................................56

Figure 25: 244-Subcatchment model, validation scatter plot. .....................................57

Figure 26: 738-Subcatchment model, validation scatter plot. ....................................57

Figure 27: 1414-Subcatchment model, validation scatter plot. ...................................58

Figure 28: Uncertainty Analysis, 78-Subcatchment model, time series, calibration (zoomed-in)

Figure 29: Uncertainty Analysis, 78-Subcatchment model, time series, validation (zoomed-in)

Figure 30: Uncertainty Analysis, 244-Subcatchment model, time series, calibration (zoomed-in). 
Figure 31: Uncertainty Analysis, 244-Subcatchment model, time series, validation (zoomed-in).

Figure 32: Uncertainty Analysis, 738-Subcatchment model, time series, calibration (zoomed-in).

Figure 33: Uncertainty Analysis, 738-Subcatchment model, time series, validation (zoomed-in). .65

Figure 34: Uncertainty Analysis, 1414-Subcatchment model, time series, calibration (zoomed-in). .66

Figure 35: Uncertainty Analysis, 1414-Subcatchment model, time series, validation (zoomed-in). .66

Figure 36: Uncertainty Analysis, line plot, Width. .67

Figure 37: Uncertainty Analysis, line plot, Slope. .................................................68

Figure 38: Uncertainty Analysis, line plot, Percent Impervious. ...................................68

Figure 39: Uncertainty Analysis, line plot, Percent Routed. .......................................69

Figure 40: Uncertainty Analysis, line plot, Curve Number. .......................................69

Figure 41: 78-Subcatchment model, with LID, zoomed-in. .................................. 71

Figure 42: 244-Subcatchment model, with LID, zoomed-in. ..................................72

Figure 43: 738-Subcatchment model, with LID, zoomed-in. ....................................72

Figure 44: 1414-Subcatchment model, with LID, zoomed-in. ....................................73

Figure 45: 78-Subcatchment model, LID scatter plot. ......................................... 74

Figure 46: 244-Subcatchment model, LID scatter plot. ........................................ 74

Figure 47: 738-Subcatchment model, LID scatter plot. ........................................75

Figure 48: 1414-Subcatchment model, LID scatter plot........................................... 75

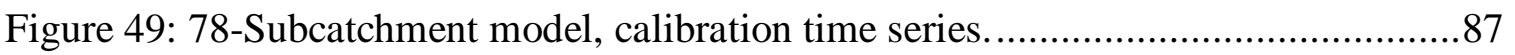

Figure 50: 244-Subcatchment model, calibration time series...................................... 88

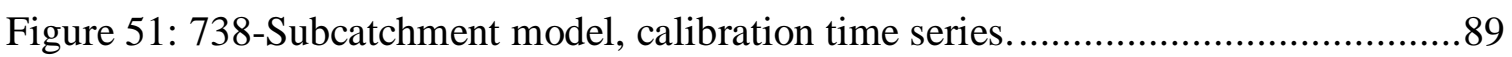

Figure 52: 1414-Subcatchment model, calibration time series. ...................................90

Figure 53: 78-Subcatchment model, validation time series.......................................91

Figure 54: 244-Subcatchment model, validation time series...................................92

Figure 55: 738-Subcatchment model, validation time series...................................93

Figure 56: 1414-Subcatchment model, validation time series.....................................94

Figure 57: Uncertainty Analysis, 78-Subcatchment model, time series, calibration. .......95

Figure 58: Uncertainty Analysis, 78-Subcatchment model, time series, validation. ........96

Figure 59: Uncertainty Analysis, 244-Subcatchment model, time series, calibration. .....97

Figure 60: Uncertainty Analysis, 244-Subcatchment model, time series, validation. ......98

Figure 61: Uncertainty Analysis, 738-Subcatchment model, time series, calibration. .....99

Figure 62: Uncertainty Analysis, 738-Subcatchment model, time series, validation. ....100

Figure 63: Uncertainty Analysis, 1414-Subcatchment model, time series, calibration. .101

Figure 64: Uncertainty Analysis, 1414-Subcatchment model, time series, validation. .. 102

Figure 65: Uncertainty Analysis, 78-Subcatchment model, Width histogram. 103 
Figure 66: Uncertainty Analysis, 244-Subcatchment model, Width histogram. ............ 103

Figure 67: Uncertainty Analysis, 738-Subcatchment model, Width histogram. ............104

Figure 68: Uncertainty Analysis, 1414-Subcatchment model, Width histogram. .......... 104

Figure 69: Uncertainty Analysis, 78-Subcatchment model, Slope histogram............... 105

Figure 70: Uncertainty Analysis, 244-Subcatchment model, Slope histogram............. 105

Figure 71: Uncertainty Analysis, 738-Subcatchment model, Slope histogram.............. 106

Figure 72: Uncertainty Analysis, 1414-Subcatchment model, Slope histogram. ........... 106

Figure 73: Uncertainty Analysis, 78-Subcatchment model, Percent Impervious

histogram.

Figure 74: Uncertainty Analysis, 244-Subcatchment model, Percent Impervious

histogram.

Figure 75: Uncertainty Analysis, 738-Subcatchment model, Percent Impervious

histogram. .108

Figure 76: Uncertainty Analysis, 1414-Subcatchment model, Percent Impervious histogram. 108

Figure 77: Uncertainty Analysis, 78-Subcatchment model, Percent Routed histogram. 109 Figure 78: Uncertainty Analysis, 244-Subcatchment model, Percent Routed histogram. .109

Figure 79: Uncertainty Analysis, 738-Subcatchment model, Percent Routed histogram.

Figure 80: Uncertainty Analysis, 1414-Subcatchment model, Percent Routed histogram.

Figure 81: Uncertainty Analysis, 78-Subcatchment model, Curve Number histogram. .111

Figure 82: Uncertainty Analysis, 244-Subcatchment model, Curve Number histogram.

Figure 83: Uncertainty Analysis, 738-Subcatchment model, Curve Number histogram.

Figure 84: Uncertainty Analysis, 1414-Subcatchment model, Curve Number histogram.

Figure 85: 78-Subcatchment model, with LID, calibration time series........................ 114

Figure 86: 244-Subcatchment model, with LID, calibration time series....................... 115

Figure 87: 738-Subcatchment model, with LID, calibration time series....................... 116

Figure 88: 1414-Subcatchment model, with LID, calibration time series ......................117

Figure 89: 78-Subcatchment model, 1-year storm hydrograph. ................................ 118

Figure 90: 78-subcatchment model, 2-year storm hydrograph................................ 118

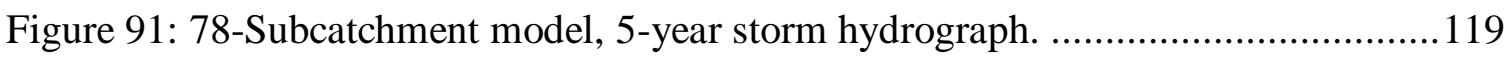

Figure 92: 78-Subcatchment model, 10-year storm hydrograph.................................119

Figure 93: 244-subcatchment model, 1-year storm hydrograph. ................................ 120

Figure 94: 244-subcatchment model, 2-year storm hydrograph. .............................. 120

Figure 95: 244-subcatchment model, 5-year storm hydrograph. .............................. 121 
Figure 96: 244-subcatchment model, 10-year storm hydrograph. ............................ 121

Figure 97: 738-subcatchment model, 1-year storm hydrograph. ................................ 122

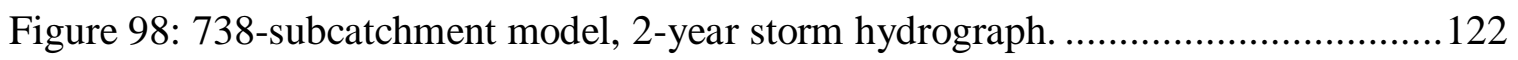

Figure 99: 738-subcatchment model, 5-year storm hydrograph. .............................. 123

Figure 100: 738-subcatchment model, 10-year storm hydrograph. ............................ 123

Figure 101: 1414-subcatchment model, 1-year storm hydrograph. ............................. 124

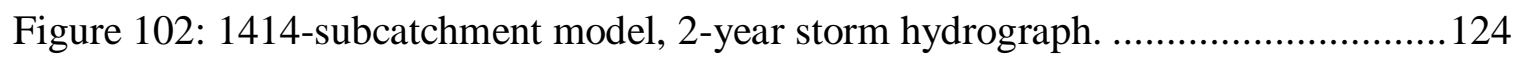

Figure 103: 1414-subcatchment model, 5-year storm hydrograph. ............................. 125

Figure 104: 1414-subcatchment model, 10-year storm hydrograph. .......................... 125 


\section{CHAPTER 1: INTRODUCTION}

As more of the world becomes urbanized, the need for accurate and reliable urban stormwater models becomes apparent. Urbanization changes the natural hydrology of a watershed, negatively impacting the ecology, geomorphology, water quality, and socioeconomic functions of the receiving water (National Research Council (NRC), 2008). Urbanization is defined as the growth of urban areas by migration of people to city areas (Mays, 2005). By increasing the amount of impervious area within a watershed, it can be expected that the amount of stormwater runoff will increase, due to the decrease of permeable soil capable of infiltration. A simple illustration of the effects of urbanization on stormwater runoff can be seen in Figure 1.

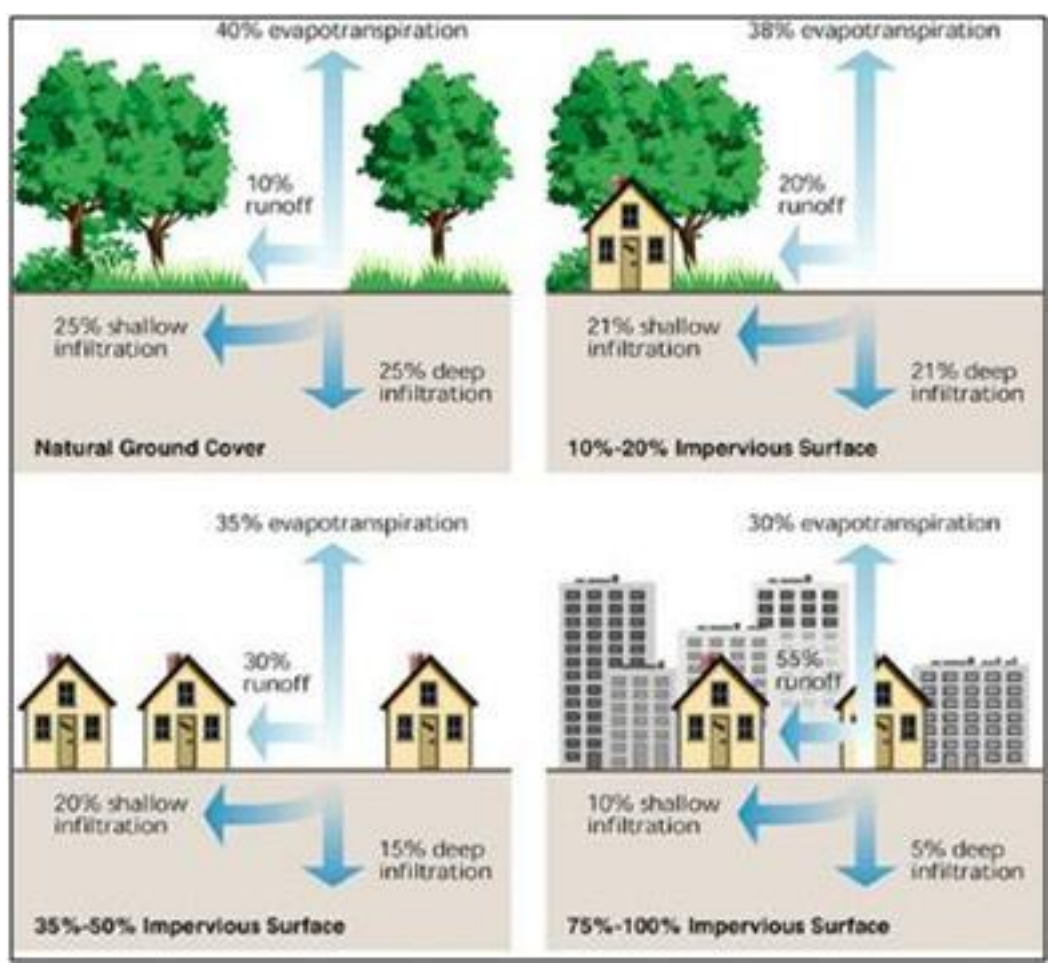

Figure 1: Illustration of the effects of urbanization on stormwater runoff (USDA Natural Resources Conservation Service, 2010). 
An increase in stormwater runoff quantity can pose a threat to the surrounding area, as well as existing infrastructure. Old stormwater drainage pipe networks were designed to handle the runoff quantity of large storms at the time they were designed and built. Now, with the increase in runoff quantity due to urbanization, the drainage networks often are not capable of handling as large a storm event as they were originally designed for, leading to severe flooding and destruction during large storm events.

Stormwater runoff alterations caused by urbanization create many problems for water resources managers and planners. Providing flood control services, keeping stormwater quality at desirable levels, and maintaining healthy aquatic ecology are typical goals for stormwater managers. Low Impact Development (LID) practices are commonly used to minimize the effects of urbanization and meet these stormwater management goals. LIDs refer to Best Management Practices (BMPs), which "encompass a wide variety of appropriate technologies and activities intended to minimize the effect of watershed development on flow regimes without altering riparian morphology" (Perez-Pedini, Limbrunner, \& Vogel, 2005). Implementing LIDs into an urban watershed is not a trivial task, however. Choosing which LIDs will perform the best, and identifying location(s) that optimize performance and cost, is an issue that water resources managers face when designing LIDs for a watershed.

Understanding the complex relationships between watershed characteristics and the runoff quantity and quality generated by a storm event is crucial for successful 
stormwater management. Runoff quantity and quality can be quantified using field measurements. Monitoring an entire watershed is, however, very difficult and expensive to keep up, especially in urban areas, where the land use and topography may be constantly changing and even some of the smallest features can alter stormwater runoff's behavior drastically. If possible, developing and maintaining field data collection would be the best way to observe how runoff behaves, but it is not realistically practical or feasible. Another method for determining stormwater runoff quantity and quality is through the use of watershed simulation models. Computer models can provide valuable insight into the performance of various features in a watershed. Being able to accurately and reliably model watersheds' response to storm events can be a cost-effective approach for stormwater management. Computer models can look at the effects that various LIDs will have on an urban watershed. This can provide valuable information as to the feasibility and practicality of implementing such LIDs into the watershed. The performance of the LIDs is dependent on the watershed properties (soil type, land cover, etc.) (City of Los Angeles, 2011), and therefore they will not perform identically if implemented in another area. The ability to model the effects that LIDs will have, on a watershed-scale, would provide valuable information as to the feasibility of implementing such LIDs.

Using stormwater models to determine these properties of the watershed is dependent on the accuracy and reliability of the model. Models must be properly calibrated in order to be used in the planning and management of water resources (Muleta, McMillan, Amenu, \& Burian, 2013). Building and calibrating watershed models is challenging. Many 
factors need to be accounted for to build an accurate watershed model, most of which are subjective and contain a lot of uncertainty.. In urban watersheds, much uncertainty exists in terms of how stormwater runoff will behave once it falls on land (Luo, Wang, Gao, Tang, \& Zhu, 2012). Establishing accurate urban stormwater models can aid in the decision-making process, and provide valuable tools for determining the feasibility of various project options (Bongiorni Ajello, Searing, Frost, \& van der Tak, 2005).

When building urban stormwater models, an important property of the model to consider is how detailed the model needs to be to accurately model the behavior of the watershed. Obtaining detailed model input data is expensive and time-consuming, and in many cases not even possible. Most of the data obtained would contain uncertainties, due to the subjective nature of the some parameters needed for stormwater models. Building a fineresolution model with data containing higher uncertainties may not be any more accurate than a model based on les detailed, coarser scaled input data with lower uncertainties. This spatial aggregation scale is an important parameter to determine when building urban stormwater models. It is important to know if taking the time and money to build a fine-resolution model is necessary, or if a less expensive, coarser-scaled model would be sufficient. 


\section{STUDY OBJECTIVES}

This study was performed with the following objectives in mind:

- Determine the effect of spatial scale on the prediction uncertainties of urban stormwater models. By building urban stormwater management models at different spatial aggregation scales, the prediction uncertainties of the models could be observed and the effect of spatial scale on prediction accuracy can be analyzed; and

- Evaluate LID performance at a watershed scale to reduce stormwater runoff volume. LID performance has been extensively researched on a small, local scale, but not as much on a watershed-scale. Modeling LID performance at the watershed-scale can give information on hydrologic effectiveness of LIDs on a larger scale, and aid in determining feasibility of watershed-scale LID implementation as a means to reduce the stormwater runoff volume.

\section{PREVIOUS WORK}

At the watershed-scale it is difficult to represent small-scale processes while maintaining reasonable computational demands (Elliott, Trowsdale, \& Wadhwa, 2009). Elliott and others (2009) studied how spatial aggregation would affect the model output for a fictional urban watershed. They used the model for urban stormwater improvement conceptualization (MUSIC) to observe the effect of varying spatial aggregation scale on 
runoff quantity and total suspended solids (TSS) concentration at the outlet of the watershed. The goal of their study was only to observe the results from the different spatial aggregation scales, not to look at any uncertainties or errors in the model itself. Therefore, no calibration or validation was done on the fictional watershed model. The results from the models showed that spatial aggregation did not play a significant role in affecting model output parameters, except for when the entire watershed was aggregated into one point source, which displayed an increase in runoff quantity of about $38 \%$. Since this study did not use any real data, and no type of calibration was done, more research is needed to determine how spatial aggregation scale really affects urban watershed modeling, before any conclusions can be drawn.

Proper and accurate calibration of watershed models is essential in the planning and decision-making processes (Mancipe-Munoz, Buchberger, Suidan, \& Lu, 2014). Two common approaches for calibrating watershed models are calibration over a single storm, and calibration over continuous storm events. The advantages of calibrating over a single storm event are the short amount of time required for calibration, and lower input data requirements. The single storm approach to calibration is most accurate for determining overall hydrograph shape and the time to peak flow for the specific storm. Calibrating over continuous storm events is more time-consuming, but it gives better results for total runoff volume estimation. For this reason, the models in this research were calibrated over continuous storm events. Mancipe-Munoz and others (2014) used the model independent parameter estimation (PEST) method to calibrate an urban watershed model of a small Ohio watershed. The PEST method is a gradient-based optimization to 
optimize model parameters. The goal of this study was to calibrate and validate an urban watershed model over continuous storm event data, which was successfully completed and found to be better for determining total runoff volume.

This research expands on the previous work done for the calibration of semi-distributed watershed models. Muleta and others (2013) looked at quantifying the uncertainties of the parameters that went into building a watershed model for the same study area as this thesis reports on, the Ballona Creek watershed in Los Angeles County (Muleta, McMillan, Amenu, \& Burian, 2013). A formal Bayesian approach for uncertainty analysis (UA) was used, rather than a more conventional calibration method used in water resources modeling. The formal Bayesian approach utilizes Markov-chain Monte Carlo (MCMC) schemes to quantify uncertainty. This approach was successful in determining parameter uncertainties as well as overall model uncertainty. Because of the success of the formal Bayesian approach, this same method of calibration and uncertainty analysis was used for this research.

A culmination of previous work led to a study done in the Syracuse, New York area (Sun, Hall, Hong, \& Zhang, 2014). The authors of this study looked at two spatial scales, micro- and macroscale, to model an urban watershed. They looked at the uncertainties of the variables using the standard generalized likelihood uncertainty estimation (GLUE) method. The models were calibrated and validated using observed sewer outflow hydrographs. One parameter calculated for the subcatchments in each model is the 
subcatchment width. This parameter was calculated according to the SWMM5 User's Manual (Rossman, 2010), using the simplifying assumption that each subcatchment is a rectangle, and the width is the total area divided by the length of the longest flowpath of water within the subwatershed. Using this parameter estimation, the models were calibrated and validated, and the effect of spatial scale on parameter uncertainties was determined for the micro- and macroscale models. It was found that the spatial scale had a significant impact on the parameter uncertainty as well as the overall model simulation results.

The method to calculate subcatchment width described above in the SWMM5 User's Manual was modified by Guo and Urbonas (Guo \& Urbonas, 2009). They researched a better estimation for subcatchment width, rather than a straightforward estimation as a rectangle; they chose to convert this rectangle estimation onto a more idealized spatial plane called the Kinematic Wave Cascading Plane. By converting an irregularly shaped subcatchment onto the new plane, the rectangle estimation to calculate width is more accurate. By changing the spatial plane, a new estimation of watershed slope must also be calculated, to match the spatial plane in which the subcatchment is now sitting. Through a series of equations involving watershed skew and shape factors to account for irregular shapes, new width and slope values can be calculated for each subcatchment. Guo and Urbonas (2009) termed this method the Shape Factor Approach, and it gives calibration a reasonable starting point. This Shape Factor Approach was utilized for this research. 
Determining the effects of LID implementation has been studied on a small scale. How these BMPs will perform on a watershed-scale has not been nearly as well-studied. Perez-Pedini and others (2005) looked at LID implementation on the watershed-scale to determine the number and locations of LID features that would have the largest impact on the modeled flood flow (Perez-Pedini, Limbrunner, \& Vogel, 2005). This research looked solely at infiltration-based LIDs, and their optimal locations within a watershed in the Massachusetts area. A spreadsheet model was built to show the optimal number of LIDs and locations that would have the greatest impact on decreasing flood flows at the outlet of the watershed. This research looks at the effects of LID implementation on the watershed-scale as well, and also expands on it to include the uncertainties of the parameters used to define and model the LIDs.

\section{UNIQUE CONTRIBUTIONS OF THIS STUDY}

All of the previous studies described above have been valuable in the research of the effects of spatial scale on urban watershed modeling. Most of the methods described above have only looked at portions of the work that needs to be done in determining the effect of spatial aggregation scale. Encompassing these past studies with new methods will give a better understanding of the problems at hand. By utilizing the latest calibration methods (Muleta, McMillan, Amenu, \& Burian, 2013), the Shape Factor Approach (Guo \& Urbonas, 2009), and the overall effect of watershed-scale LID 
implementation (Perez-Pedini, Limbrunner, \& Vogel, 2005), some of the limitations of past methods and studies can be expanded on. Combining the concepts from these previous studies with this research improves our understanding of how spatial aggregation affects urban stormwater modeling, and the effects of watershed-scale LID implementation.

This research contributes to the water resources engineering field in a couple different ways. Spatial aggregation scale has been previously studied (Sun, Hall, Hong, \& Zhang, 2014), but only at two different scales (microscale and macroscale). This research looks at four different spatial scales. The previous study's results showed that the spatial aggregation scale had a large impact on the uncertainties of parameters in the models, and that the parameters were sensitive to spatial scale. Since this study looked at only two drastically different spatial scales, it is only apparent that spatial scale does significantly affect urban stormwater modeling in the sense of micro- and macroscale. This study shows how intermediate scales will affect the urban stormwater modeling, as well as the micro- and macroscales studied previously. 
Modeling LID implementation has been previously researched at small, local scales (Elliott, Trowsdale, \& Wadhwa, 2009). Not much work has been done on modeling LID implementation on the watershed-scale. At local scales (i.e., for individual devices), LIDs can have a significant effect on mediating stormwater runoff quantity in that area, but the effect that watershed-scale LID implementation will have on a watershed has not been studied. This research shows how implementing LIDs on the watershed-scale affects overall stormwater runoff quantity. 


\section{CHAPTER 2: METHODOLOGY}

In order to study the effect of spatial aggregation scale, models at various spatial scales had to be built. These models must then be calibrated and verified using observed data to ensure accuracy and reliability. For this research, the Ballona Creek watershed, located in Los Angeles County, was chosen as the study area. The Ballona Creek watershed was chosen due to its highly urbanized land base, and current issues associated with stormwater runoff (City of Los Angeles Stormwater Program, 2014).

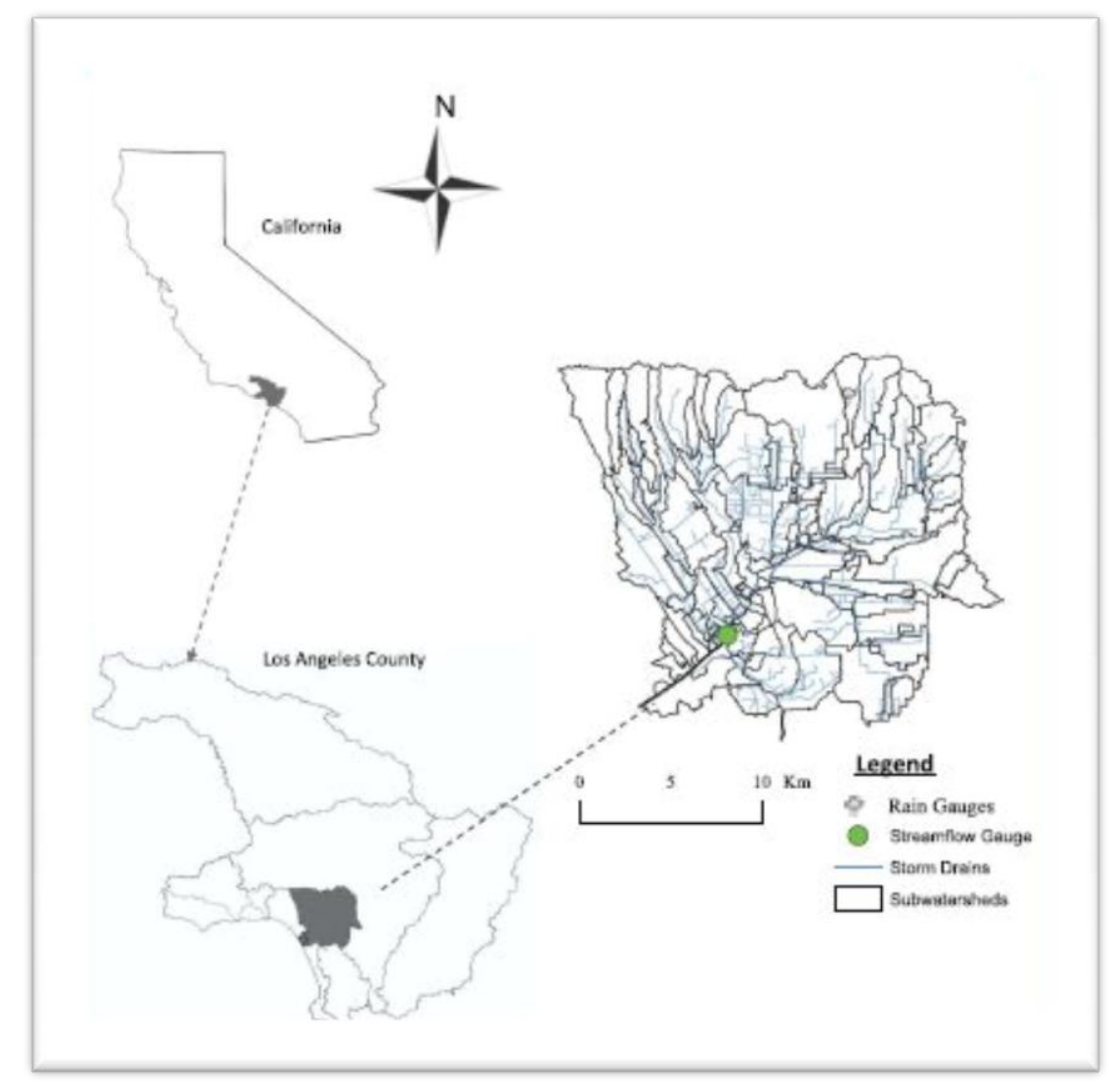

Figure 2: Location map of Ballona Creek watershed (Muleta, McMillan, Amenu, \& Burian, 2013). 


\section{BALLONA CREEK WATERSHED}

The Ballona Creek Watershed is a highly urbanized watershed that lies in Los Angeles County. The 130-square-mile watershed ranges from the Santa Monica Mountains in the north, the Harbor Freeway (I-110) on the east, and Baldwin Hills in the South. The watershed consists of the cities of Beverly Hills, Culver City, Inglewood, Los Angeles, Santa Monica, and West Hollywood. The watershed is $64 \%$ residential, $8 \%$ commercial, 4\% industrial, and 17\% open space; over 75\% urbanized (County of Los Angeles, 2013). All of the stormwater runoff generated within the watershed drains into Ballona Creek, a concrete-lined, trapezoidal-shaped open channel, which feeds directly into the Pacific Ocean at Santa Monica Bay.

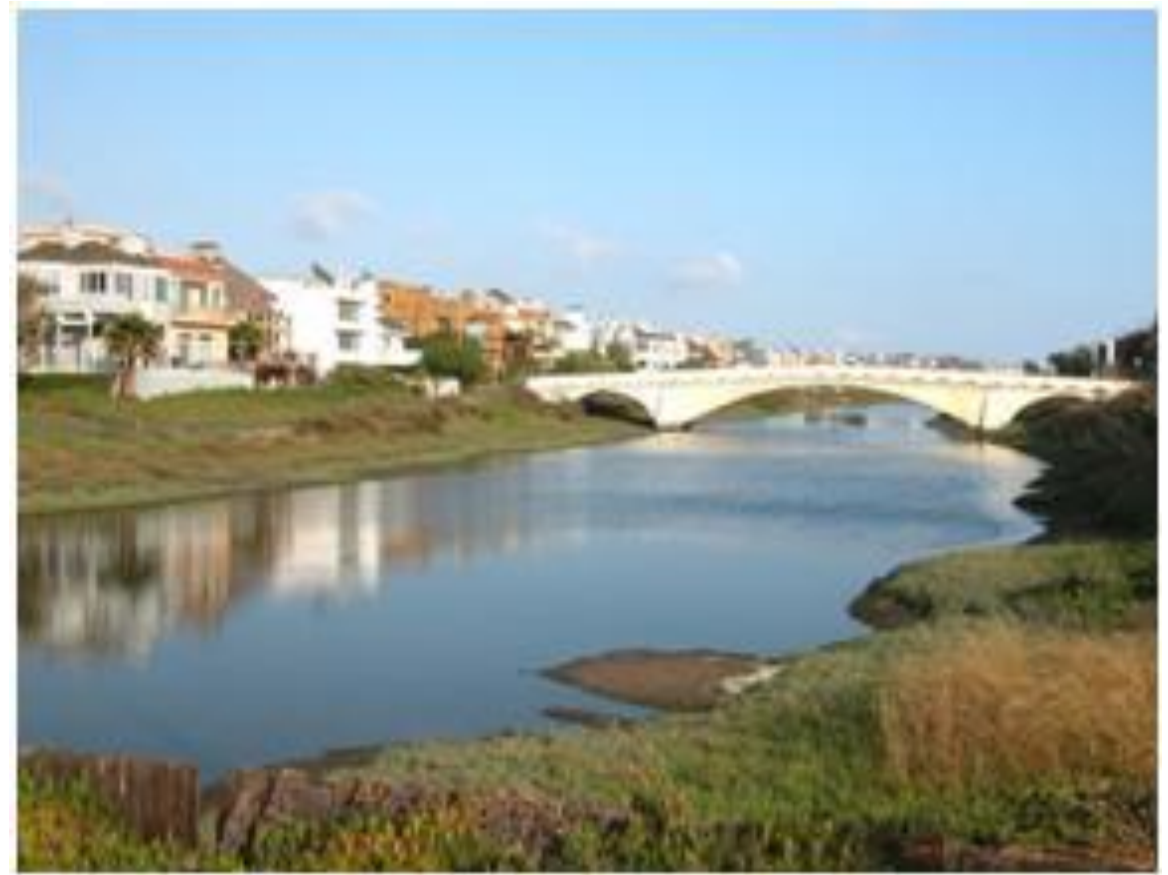

Figure 3: Ballona Creek, a 9-mile long flood control channel in Los Angeles County (County of Los Angeles, 2013). 
Ballona Creek was historically a natural channel containing small flows year-round. During the rainy season the creek would fill and flood the surrounding Los Angeles areas. In the 1920's the County of Los Angeles began to straighten the creek to allow for more development in the surrounding area. In the 1930's the Army Corps of Engineers took over the project, and carved out a channel and lined it with concrete. The project included the construction of many smaller storm drains leading to Ballona Creek, mostly underground (Malsin, 2013). This massive project aimed to increase the speed at which the stormwater runoff would reach the ocean, therefore allowing less time for it to accumulate and flood the heavily urbanized surrounding area. While this goal was met, it came with many negative impacts as well. Ballona Creek contains the polluted urban runoff from the entire watershed, placing Ballona Creek on the Los Angeles Regional Water Quality Control Board impaired list for fecal coliform, heavy metals, and pesticides (California Environmental Protection Agency, 2014). These are contributed by dry-weather urban runoff and stormwater.

By straightening and lining Ballona Creek, the travel time of water from the watershed to the Santa Monica Bay is significantly decreased. The channel was designed and sized to be able to handle the 50-year frequency storm event, 71,400-cubic feet per second (County of Los Angeles, 2013). At the time it was constructed this was a sufficient design capacity, but since that time the watershed has become more heavily urbanized. The urbanization of the Ballona Creek watershed has increased the quantity of stormwater runoff generated from smaller storms. This increase in stormwater runoff 
quantity poses a flooding risk to the urbanized watershed with a recurrence frequency now below a 50-year storm event.

Implementing LIDs throughout the watershed could have a significant effect in mediating the increase in stormwater runoff, as well as stormwater quality. Various LIDs are available that promote infiltration, evapotranspiration, and use of stormwater, that may reduce stormwater runoff and improve stormwater quality. LIDs are capable of removing pollutants from stormwater, and reducing volume and peaks of stormwater flow (City of Los Angeles, 2011). While these LIDs are ultimately beneficial in terms of reducing stormwater runoff quantity, the cost of implementing such LIDs must be taken into account when determining the feasibility of such projects.

By modeling the Ballona Creek watershed, it could be determined how LID implementation would affect the stormwater runoff quantity generated. Accurately modeling this urban watershed consists of all the challenges normally associated with urban watershed modeling. There is much uncertainty involved with the parameters that go into building a watershed model. One important property of the model-building process is the spatial scale at which the model should be constructed. Choosing an inappropriate spatial scale at which to build the model, and analyze, could provide inaccurate results leading to costly mistakes. 


\section{EPA SWMM}

The modeling program chosen to model the Ballona Creek watershed for this research was the Environmental Protection Agency (EPA)'s Stormwater Management Model (SWMM). SWMM is a dynamic rainfall-runoff simulation model that encompasses single storm events as well as continuous simulations. SWMM was first developed in 1971, but has since gone through major transformation to where it is at today, SWMM 5.0, a Windows-based modeling software. SWMM is typically used to model urban watersheds, due to capabilities of simulating both stormwater runoff quantity and water quality (Rossman, 2010).

SWMM uses a series of physical features to model a stormwater drainage system. For this model, rain gages, subcatchments, junction nodes, and conduits were used to model the Ballona Creek watershed. The stormdrain network for Ballona Creek features many different geometries for conduits, all of which were chosen from SWMM's library of available conduits. SWMM utilizes Manning's equation to relate the cross-sectional areas of conduits and flowrates. There are three different methods of flow routing native to SWMM, Steady Flow Routing, Kinematic Wave Routing, and Dynamic Wave Routing. Kinematic Wave Routing was chosen as the flow routing method for this study. Kinematic Wave Routing solves both the continuity equation and a simplified version of the momentum equation for each conduit simultaneously. This method was chosen for analysis for ease of use as well as computational ability. Running a continuous (longterm) watershed model is computationally demanding. Kinematic Wave Routing is 
generally stable for large time steps. For this study, the models simulated runoff for periods of months, with time steps of 5-minutes.

An important feature of SWMM is its ability to model LID features. SWMM models LID features as vertical layers on top of, below, or in the middle of the subcatchment, based on the LID features' properties. SWMM calculates runoff, storage, and evapotranspiration. The flow from a subcatchment is routed through the LID features before being conveyed into the conduit system. For this study, the LID feature Bioretention Cells were examined, and the change in runoff at the outlet of the watershed compared to without the LID feature. All information in this section was taken from the Stormwater Management Model User’s Manual, Version 5.0 (Rossman, 2010).

\section{DATA AND DATA PROCESSING}

In order to parameterize the watershed model, various data must be collected, organized, compiled, and manipulated into files readable by modeling software. All of these datasets come from different sources, and in different formats. They must all be manipulated into file types and formats that can be combined and used together to build the model. The use of ESRI's ArcGIS provided the management of databases and storage of the data for input into EPA's SWMM. The data needed for watershed modeling includes elevation, land cover, soil type, and imperviousness areas, as well as the drainage network features, and rainfall data (Nakamura \& Villagra, 2009). 
The elevation data was downloaded as a digital elevation model (DEM) from the United States Geological Survey’s (USGS) website (http://viewer.nationalmap.gov/viewer). The land cover data and the imperviousness data was also downloaded from USGS (United States Geological Survey (USGS), 2013). The Los Angeles County’s website (http://egis3.lacounty.gov/dataportal/2011/01/27/soil-types) contained the most up-todate soil data for the Ballona Creek watershed (County of Los Angeles, 2013). Data provided by the University of Utah (Burian, McPherson, Brown, \& Turin, 2000) included a shapefile of GIS polylines with all the information about the drainage network for the watershed. This data included stormdrain location, geometry (size, length), Manning's roughness coefficients, invert elevations, and slopes.

Each model built underwent the same overall procedure, using the same datasets to ensure that spatial scale was the only varying parameter between the models. The Army Corps of Engineers software extension for ArcGIS, HEC-GeoHMS, was used to generate subcatchments within the watershed and their corresponding properties. The HECGeoHMS extension for GIS is a public domain software package designed to create the data inputs needed for a HEC-HMS watershed model. The datasets needed for a HECHMS model are, for the most part, similar to those needed to build a watershed model in SWMM, so the HEC-GeoHMS tools proved to be a straightforward and efficient way to generate these specific sets of data. Provided here is a brief description of the procedures used in the HEC-GeoHMS program. For more in-depth details on each step, the reader 
may refer to the HEC-GeoHMS user's manual

(http://www.hec.usace.army.mil/software/hec-geohms/documentation/HEC-

GeoHMS_Users_Manual_4.2.pdf) (United States Army Corps of Engineers, 2009). The

HEC-GeoHMS tools can be grouped into two: Terrain Preprocessing and Basin

Processing. The tools within each part provide the input datasets necessary to create a

SWMM watershed model.

\section{TERRAIN PROCESSING}

The Ballona Creek watershed is highly urbanized, and the drainage network of pipes and open channels plays a large role in how stormwater behaves once it falls and runs off. The DEM downloaded from the USGS was simply raw ground elevation data; it omits all buildings and any other types of manmade structures. To accurately model the true terrain of the watershed, this raw DEM is not sufficient (Joseph, 2012). The DEM Reconditioning tool in the HEC-GeoHMS toolbox allows the DEM to be manipulated to more accurately represent the drainage network. The drainage network shapefile obtained from the University of Utah (Burian, McPherson, Brown, \& Turin, 2000) was overlaid on top of the DEM, and the elevations and slopes of the polylines imprinted onto the DEM, changing the elevation values "underneath". This DEM Reconditioning tool created a new raster dataset of elevations that more accurately represented how the water would behave on the given topography. 
The next tool used is the Fill Sinks tool. This tool looks at the DEM (reconditioned DEM) and fills in small local sinks and cuts out small local peaks. Once this is done, the Flow Direction tool is used next. This tool takes the output raster from the Fill Sinks tool and outputs a new raster that is a water flow direction grid. This output is then put into the Flow Accumulation tool, which shows where the water will accumulate, to initiate defined flow channels, within the watershed. Each model was built identically up to this point. The next tool used is the Stream Definition tool. This is where the spatial scale and resolution of each model was chosen. For more information on spatial scale, refer to Chapter 3, section Spatial Aggregation. The Catchment Delineation tool is used next. This takes the defined streams and assigns corresponding catchment areas for each. Everything done up until this point uses raster data as the input, and outputs a new raster data set.

Once all the raster data described above has been created, the data must be turned into vector format (GIS feature classes). The Catchment Polygon Processing tool, the Drainage Line tool, and the Adjoint Catchment tool complete the terrain preprocessing. These tools take the raster data created in the previous tools, and combines them all to give polyline and polygon features with parameters and properties from the created raster data. This completes the Terrain Preprocessing portion of the HEC-GeoHMS tools. 


\section{BASIN PROCESSING}

Generating a HEC-GeoHMS Project is the first step in Basin Processing. After selecting a project outlet point, the Generate Project tool finds the area of the watershed that drains to this point. By selecting the outlet of Ballona Creek into Santa Monica Bay as the outlet point, the entire watershed was selected as the drainage area of interest. Generating the project gives polygon vector files for the subcatchments created, as well as a polyline vector file with each river within the subcatchments. This subcatchment feature class has most of the parameters and properties needed for the SWMM model, but is missing some important parameters, such as Curve Number and Percent Impervious for each subcatchment.

The data previously downloaded can now be utilized to finish filling out the subbasin attribute table. Using the imperviousness data grid from USGS, ArcGIS was used to calculate a percentage of each subbasin that was impervious and it was added to its respective field in the attribute table. The land cover and soil data had to be merged together, as well as create a Curve Number Lookup Table, in order to come up with an average Curve Number for each subcatchment.

The Curve Number Lookup Table was created using standard curve numbers from the TR-55 Hydrologic Manual (United States Department of Agriculture (USDA), 1986), as well as the Hydrologic Soil Group (HSG) for the soils in the watershed. The TR-55 
Manual was used to come up with representative curve numbers for each type of land cover and soil combination. Table 1 shows the curve numbers.

Table 1: Curve Number Table

\begin{tabular}{|c|c|c|c|c|c|}
\hline Code & Land Use & \multicolumn{4}{|c|}{$\begin{array}{c}\text { Hydrologic Soil } \\
\text { Group }\end{array}$} \\
\hline & & A & B & C & D \\
\hline 11 & Open Water & 100 & 100 & 100 & 100 \\
\hline 21 & Developed, Open Space & 49 & 69 & 79 & 84 \\
\hline 22 & Developed, Low Intensity & 51 & 68 & 79 & 84 \\
\hline 23 & Developed, Medium Intensity & 61 & 75 & 83 & 87 \\
\hline 24 & Developed, High Intensity & 89 & 92 & 94 & 95 \\
\hline 42 & Evergreen Forest & 36 & 60 & 73 & 79 \\
\hline 43 & Mixed Forest & 30 & 55 & 70 & 77 \\
\hline 52 & Shrub/Scub & 48 & 67 & 77 & 83 \\
\hline 71 & Grassland/Herbaceous & 49 & 69 & 79 & 84 \\
\hline 90 & Woody Land & 43 & 65 & 76 & 82 \\
\hline
\end{tabular}

The soil type present in each subcatchment was assigned a Hydraulic Soil Group (HSG) grade/letter corresponding to the type of soil present in the soil data downloaded from USGS. In Table 2 the HSGs marked with an asterisk (*) were found directly from the TR-55 Manual (United States Department of Agriculture (USDA), 1986) and the rest were assigned based on Figure 4. 


\begin{tabular}{|cl|}
\hline HSG & \multicolumn{1}{c|}{ Soil textures } \\
\hline A & Sand, loamy sand, or sandy loam \\
B & Silt loam or loam \\
C & Sandy clay loam \\
D & Clay loam, silty clay loam, sandy clay, silty \\
& clay, or clay \\
\hline
\end{tabular}

Figure 4: Hydrologic Soil Group assumptions (United States Department of Agriculture (USDA), 1986).

Table 2: Hydrologic Soil Group Table

\begin{tabular}{|c|c|c|}
\hline Code & Soil Name & HSG \\
\hline 002 & Altamont Clay Loam & $\mathrm{D}$ \\
\hline 003 & Chino Silt Loam & $\mathrm{B} / \mathrm{C}$ \\
\hline 004 & Diablo Clay Loam & $* \mathrm{D}$ \\
\hline 006 & Hanford Fine Sandy Loam & $* \mathrm{~A}$ \\
\hline 007 & Hanford Gravelly Sandy Loam & $* \mathrm{~A}$ \\
\hline 008 & Hanford Silt Loam & $* \mathrm{~B}$ \\
\hline 009 & Montezuma Clay Abode & $\mathrm{A}$ \\
\hline 012 & Ramona Clay Loam & $\mathrm{C}$ \\
\hline 013 & Ramona Loam & $\mathrm{C}$ \\
\hline 016 & Yolo Loam & $* \mathrm{~B}$ \\
\hline 017 & Yolo Clay Loam & $* \mathrm{D}$ \\
\hline 020 & Santa Monica Mountains & $* \mathrm{D}$ \\
\hline 021 & Santa Monica Mountains & $* \mathrm{D}$ \\
\hline 040 & Santa Monica Mountains & $* \mathrm{D}$ \\
\hline 042 & Santa Monica Mountains & $* \mathrm{D}$ \\
\hline 043 & Santa Monica Mountains & $* \mathrm{D}$ \\
\hline 066 & Upper Los Angeles River & $* \mathrm{D}$ \\
\hline 069 & Upper Los Angeles River & $* \mathrm{D}$ \\
\hline
\end{tabular}


The Curve Number grid could then be generated, and an average curve number assigned to each subcatchment. This completed the use of ArcGIS to compile and manipulate the obtained data.

DATA INPUT INTO SWMM

The HEC-GeoHMS tools manipulated the data to be put into SWMM. Each model utilized the data generated from HEC-GeoHMS as well as rainfall data from three rain gages (Hollywood 312, Swattle 370, and USC 375) provided by the Los Angeles County Department of Public Works (County of Los Angeles, 2013).This rainfall data was collected using automatic gauges equipped with real-time data telemetry and electronic data loggers (Amenu, 2011) The locations of these rain gages can be seen in Figure 5, Figure 6, and Figure 7. The necessary data for the SWMM models are outlined in Table 3. 


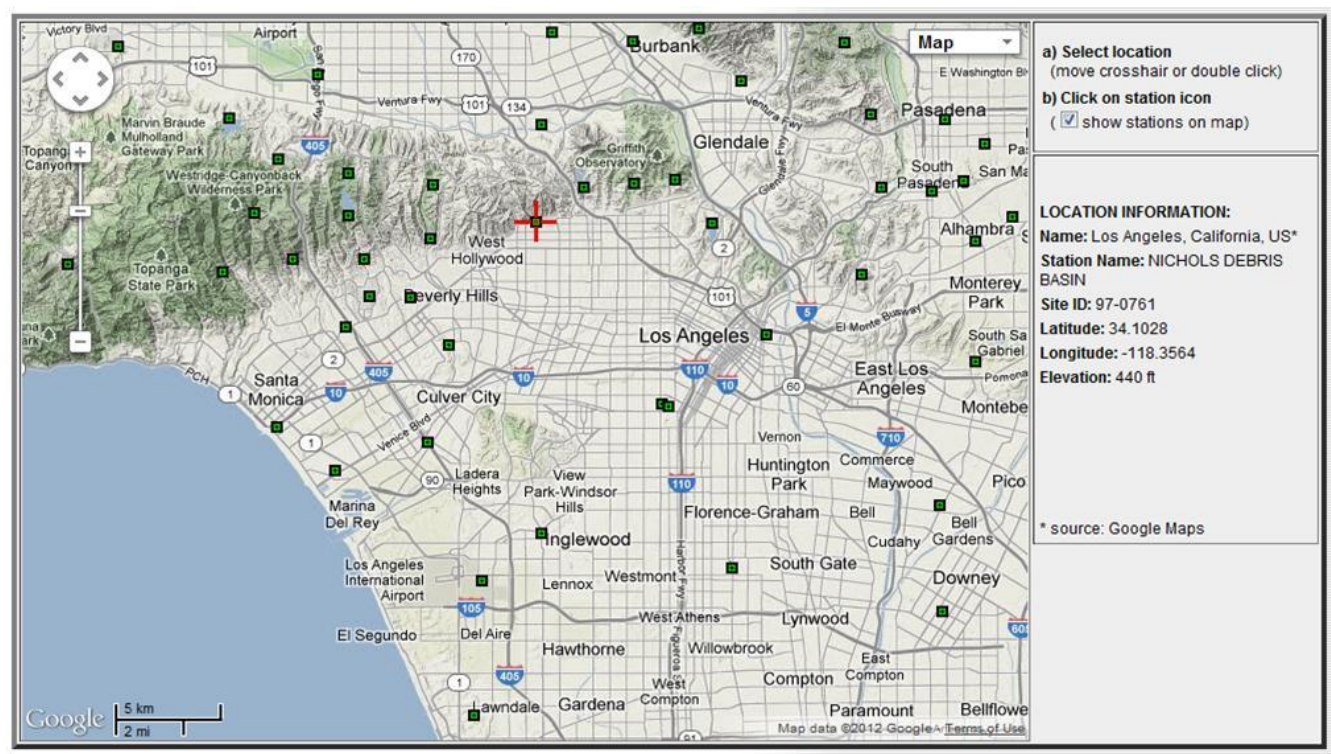

Figure 5: Location of Hollywood312 rain gage (Google, 2014).

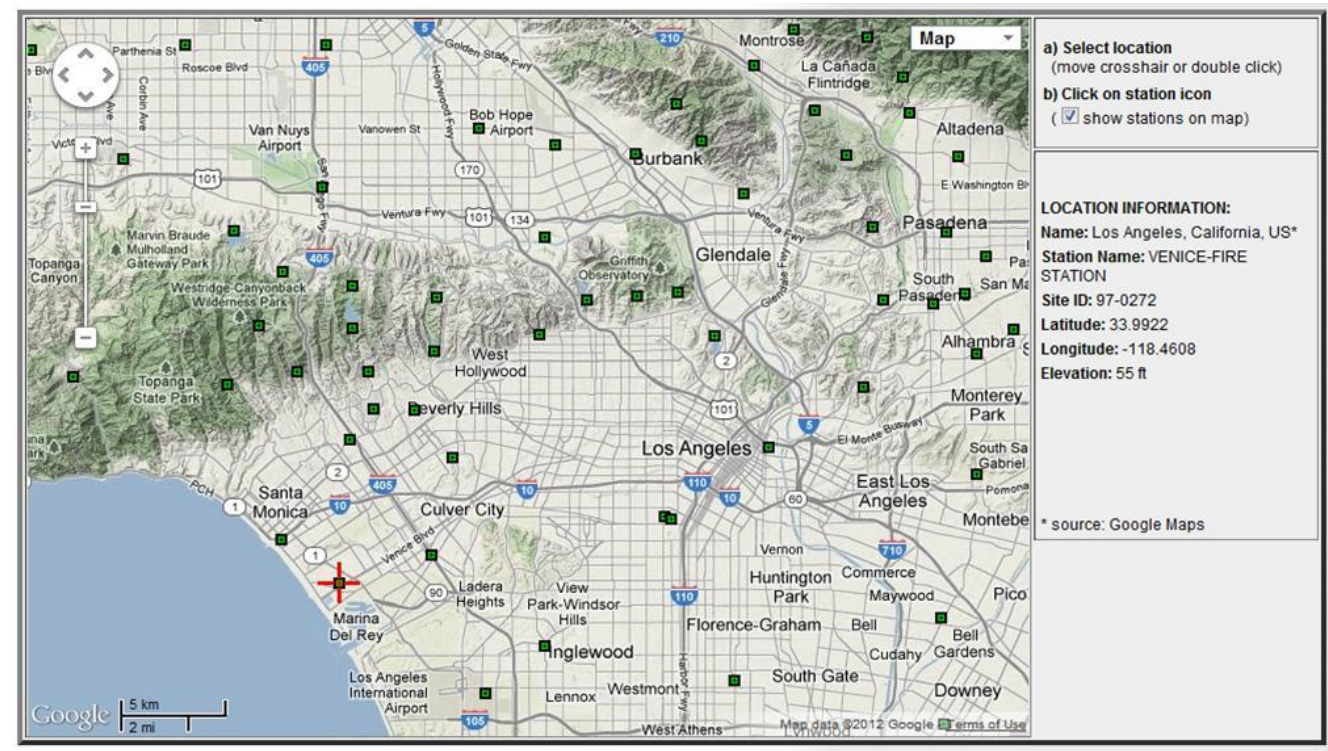

Figure 6: Location of Swattle370 rain gage (Google, 2014). 


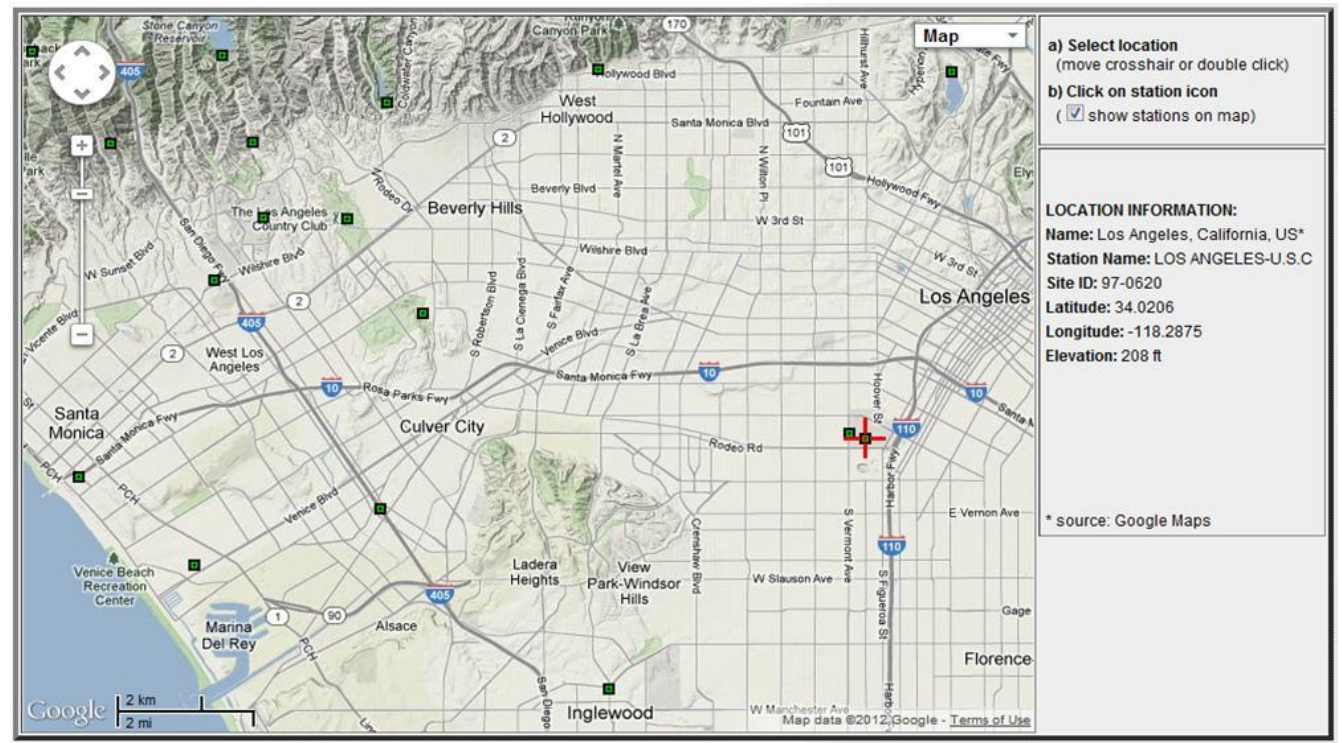

Figure 7: Location of USC375 rain gage (Google, 2014).

Table 3: SWMM Data Input Table

\begin{tabular}{|c|c|c|}
\hline Subcatchments & Conduits & \multirow{2}{*}{ Junctions } \\
\hline Rain Gage & Inlet Node & Invert Elevation (ft) \\
\hline Outlet Junction & Outlet Node & Maximum Depth (ft) \\
\hline Area (acre) & Shape (Geometry) & \\
\hline Width (ft) & Maximum Depth (ft) & \\
\hline Slope (\%) & Length (ft) & \\
\cline { 1 - 2 } Percent Impervious & Roughness (n) & \\
\hline Curve Number & \multicolumn{2}{|}{} \\
\hline
\end{tabular}

The University of Utah shapefile (Burian, McPherson, Brown, \& Turin, 2000) provided all of the data necessary for the Conduits and the Junctions. The drainage network shapefile was laid over the subcatchment and river layers created by HEC-GeoHMS, and where the rivers drainage network data coincided, the geometry for those corresponding polylines were applied to the river data, which was then imported into SWMM as the 
conduits for each model. The endpoints of each river polyline were assigned an elevation from the reconditioned DEM for an elevation, and it was assumed that each pipe/conduit lay 10-ft below the ground surface, giving a maximum depth of 10-ft higher than the downstream conduit depth. Each subcatchment was assigned a corresponding rain gage based on their relative proximity to the three rain gages. Outlet junctions were determined by following the flow direction grid from the centroid of each subcatchment to the nearest downstream junction. ArcGIS automatically calculated the area of each subcatchment polygon, and only a simple coordinate projection calculation was necessary to obtain each area in acres. The HEC-GeoHMS tools described above provided each subcatchment with a Percent Impervious and a Curve Number. The only data still necessary for the SWMM models were subcatchment Width and subcatchment Slope. These were calculated using the Guo and Urbonas Shape Factor Approach (Guo \& Urbonas, 2009).

The Guo and Urbonas Shape Factor Approach (Guo \& Urbonas, 2009) utilizes various empirical equations to determine an appropriate width and correspond slope for a subcatchment. Equation 1 is used to calculate the subcatchment shape factor.

\section{Equation 1:}

$$
X=A / L^{2}
$$

Where:

$$
\begin{aligned}
& X=\text { shape factor } \\
& A=\text { subcatchment area } \\
& L=\text { length of longest flowpath }
\end{aligned}
$$


This shape factor is then adjusted to be on an idealized plane using Equation 2.

Equation 2:

$$
Y=2 X *(1.5-Z) *(2 K-X) / 2 K-1
$$

Where:

$$
\begin{aligned}
& Y=\text { idealized subcatchment shape factor } \\
& \mathrm{X}=\text { shape factor } \\
& \mathrm{Z}=\text { skew factor (larger area on one side of the drainage channel divided by the } \\
& \text { total area) } \\
& \mathrm{K}=\text { upper limit on the watershed shape factor (recommended between } 4 \text { and } 6 \text { ) }
\end{aligned}
$$

For the use of this equation, the skew factor $(\mathrm{Z})$ was assumed to be 0.5 , as a simplification saying that each subcatchment is symmetrical about the longest flowpath, and the upper limit of the watershed shape factor $(\mathrm{K})$ was assumed to be 4 , as recommended by Guo and Urbonas (2009). Using this idealized shape factor, the subcatchment width can be calculated using Equation 3.

\section{Equation 3:}

$$
W=A / L Y
$$

Where:

$$
\begin{aligned}
& \mathrm{W}=\text { subcatchment width } \\
& \mathrm{A}=\text { subcatchment area } \\
& \mathrm{Y}=\text { idealized subcatchment shape factor }
\end{aligned}
$$


Since this width has been calculated using an idealized shape factor, and altering the true plane at which the subcatchment lays, the subcatchment slope determined by HECGeoHMS must be adjusted. Subcatchment slope was originally calculated using the HEC-GeoHMS tools. The method used to calculate the slope uses a Slope Grid raster dataset that was created using the HEC-GeoHMS terrain preprocessing tool Basin Slope. The Slope Grid is a dataset consisting of a slope value for each cell in the raster. The Basin Slope tool finds an average slope value for each subcatchment and assigns that average value to the subcatchment as the slope. The idealized basin slope is calculated using Equation 4.

\section{Equation 4:}

$$
S=S_{0} * L / W+Y L
$$

Where:

$$
\begin{aligned}
& \mathrm{S} \text { = idealized subcatchment slope } \\
& \mathrm{S}_{\mathrm{O}}=\text { subcatchment slope (as calculated using HEC-GeoHMS Basin Slope tool) } \\
& \mathrm{L}=\text { length longest flowpath } \\
& \mathrm{W}=\text { subcatchment width } \\
& \mathrm{Y}=\text { idealized subcatchment shape factor }
\end{aligned}
$$

Each model was built using the methods and procedures as described above. 


\section{CHAPTER 3: WATERSHED MODELING}

The methods and procedures discussed previously were used to parameterize the

watershed models used for this research. This chapter discusses how the different spatial aggregation scales were created for each model simulation, the calibration and verification of the models simulations, as well as the BMP design process.

\section{SPATIAL AGGREGATION}

Each model was built using the same data and procedures described previously. Where the models differ is defined by how the Stream Definition tool is used in the Terrain Processing steps of HEC-GeoHMS. To use this tool a threshold must be assigned for how much accumulated flow defines a stream. By changing the threshold for which the process determines what defines a stream or a catch basin for this project, different levels of detail could be chosen. For each model, a different number of cells was chosen to define a stream. "This step classifies all cells with a flow accumulation greater than the user-defined threshold as cells belonging to the stream network. Typically, cells with high flow accumulation, greater than the user-defined threshold value, are considered part of a stream network. The flow accumulation for a particular cell must exceed the userdefined threshold for a stream to be initiated." (United States Army Corps of Engineers, 2009). Therefore, the smaller the threshold, the smaller the amount of flow accumulation that would be used to define a stream, and therefore, a more fine resolution model of 
subcatchments will be generated. Shown below in Table 4 are the thresholds and corresponding areas that were used to generate the different spatial scales for modeling.

Table 4: Stream Definition Threshold Table

\begin{tabular}{|c|c|c|c|}
\hline Model & Cell Threshold (\#) & Area (acre) & Subcatchments Generated (\#) \\
\hline 1 & 20000 & 450 & 78 \\
\hline 2 & 15000 & 325 & 244 \\
\hline 3 & 1500 & 30 & 738 \\
\hline 4 & 750 & 15 & 1414 \\
\hline
\end{tabular}

These various spatial aggregations were chosen to model the Ballona Creek at different spatial scales; the 78-Subcatchment model the coarsest resolution model, the 1414Subcatchment model the finest resolution model, and two aggregations in the middle as intermediate spatial scales. Figure 8 through Figure 11 show the subcatchment delineations for each of the four models built. Table 5 shows more details on the properties and nature of each model. 


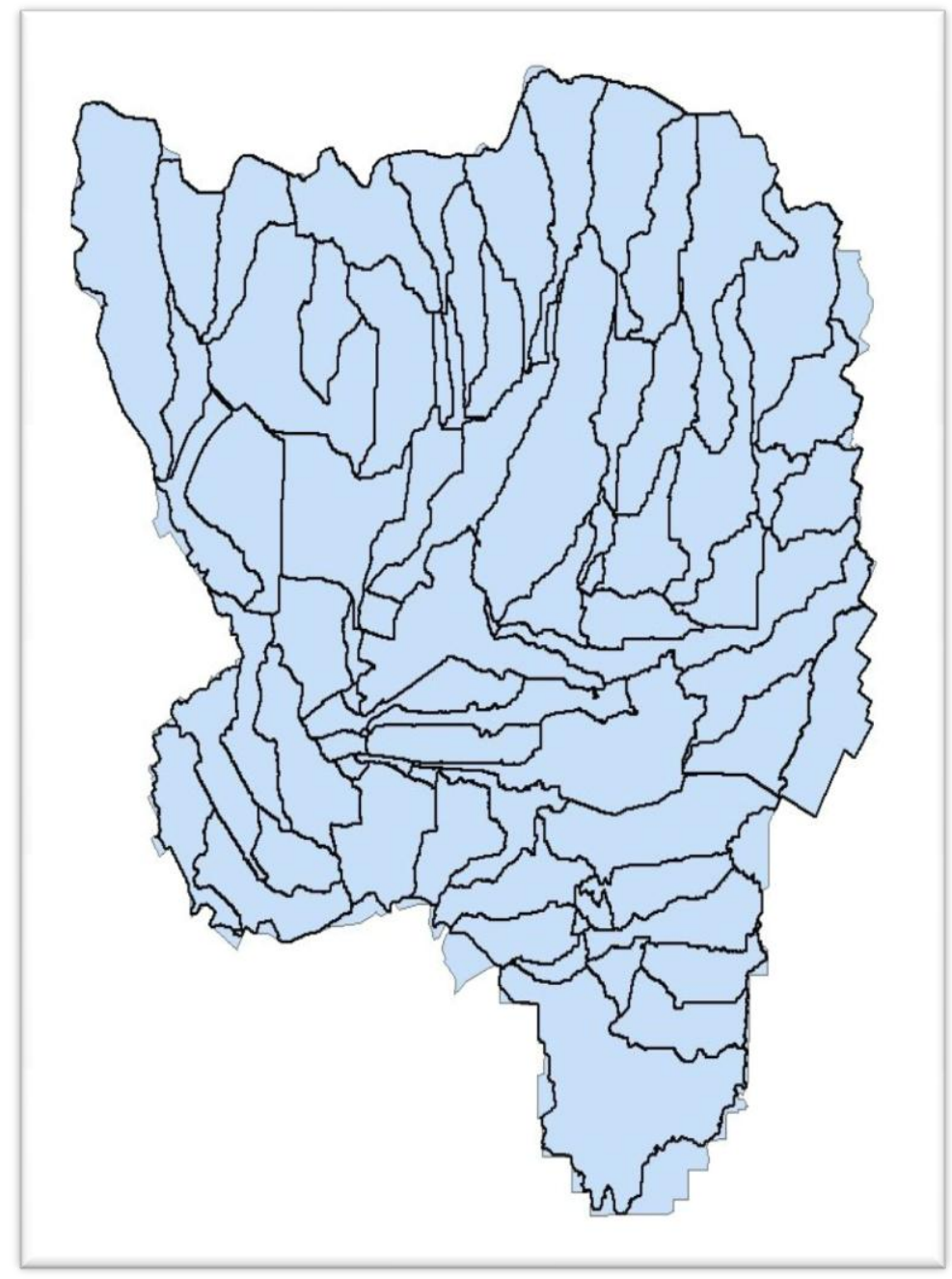

Figure 8: 78-Subcatchhment model, subcatchment delineations. 


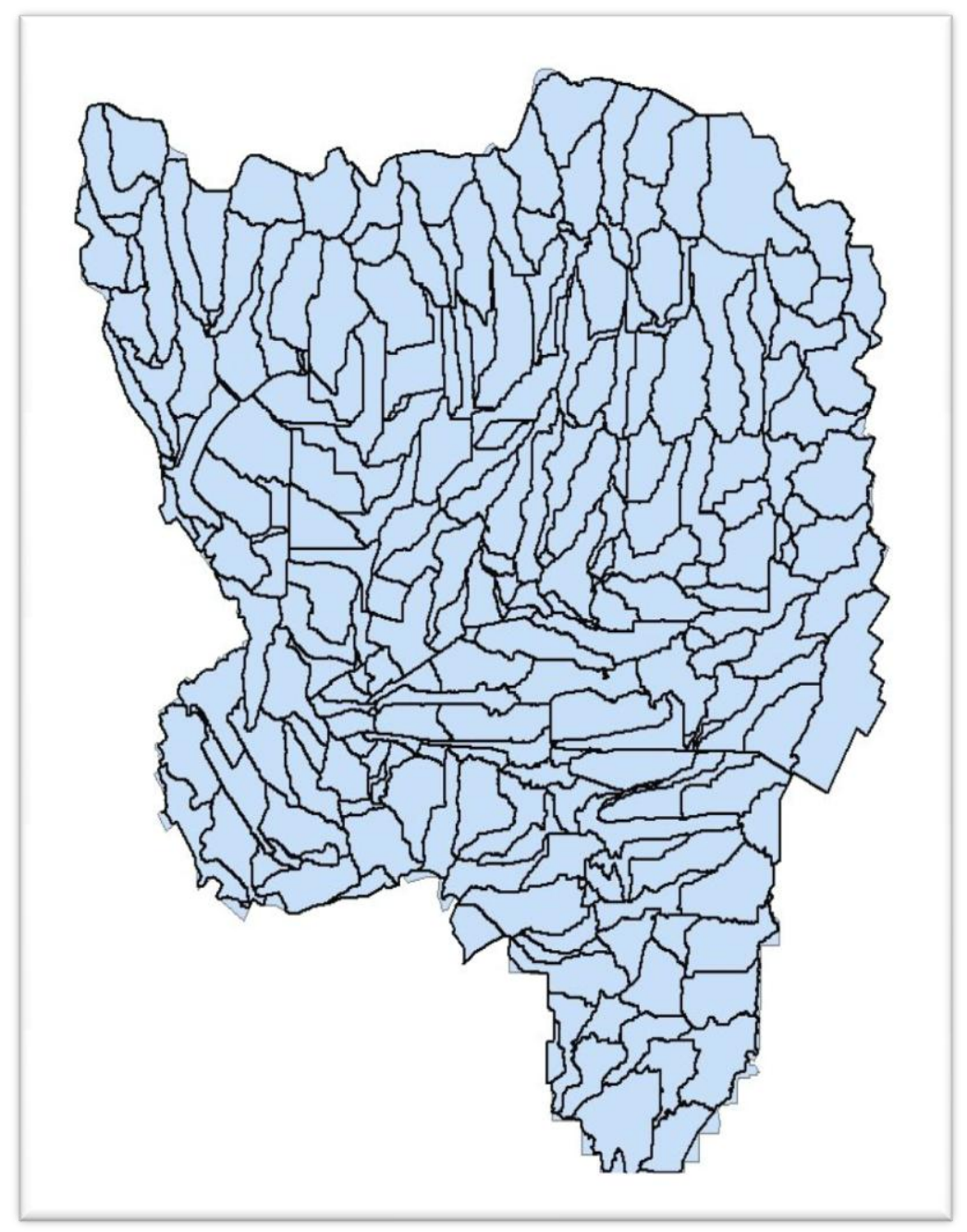

Figure 9: 244-Subcatchment model, subcatchment delineations. 


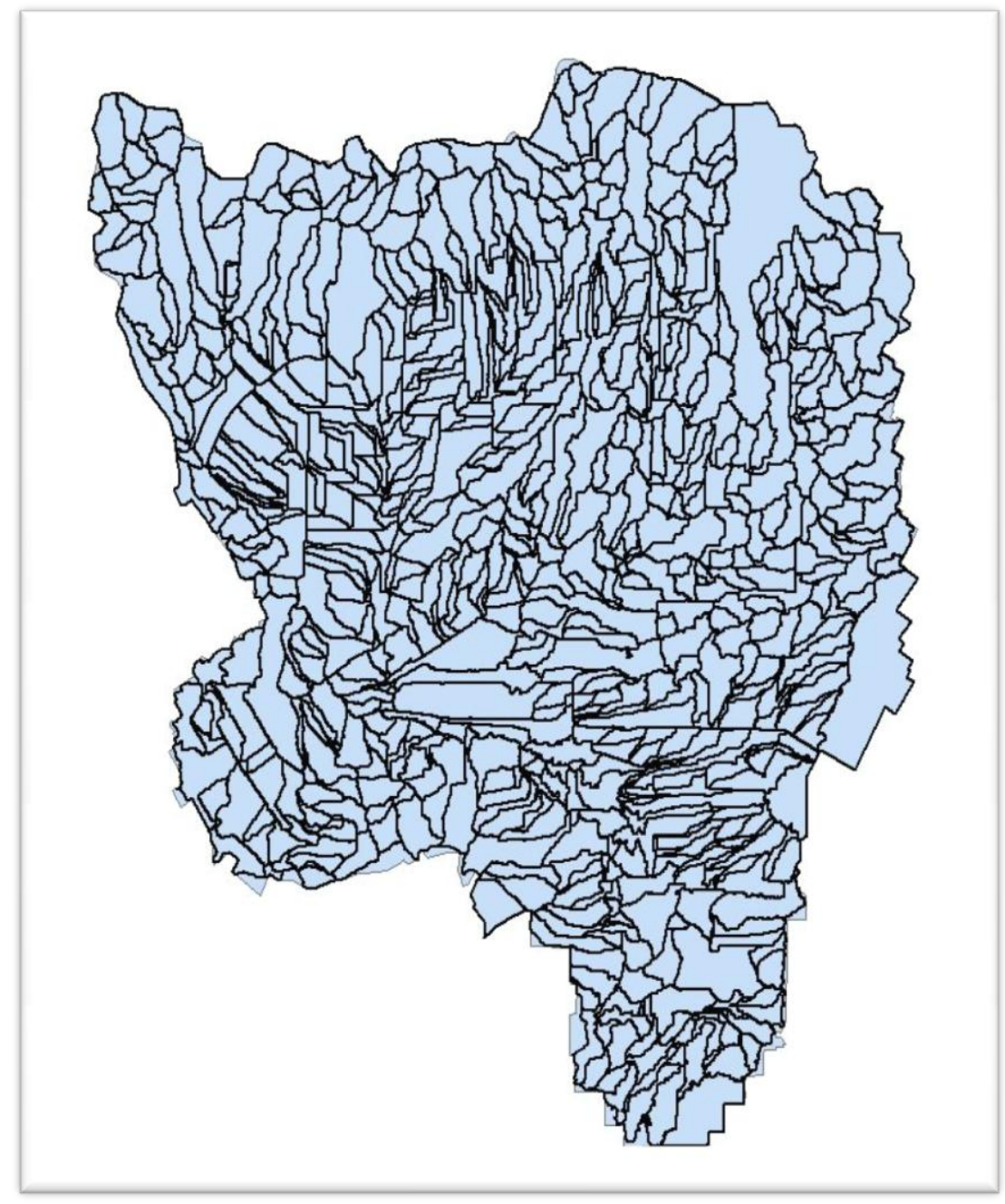

Figure 10: 738-Subcatchment model, subcatchment delineations. 


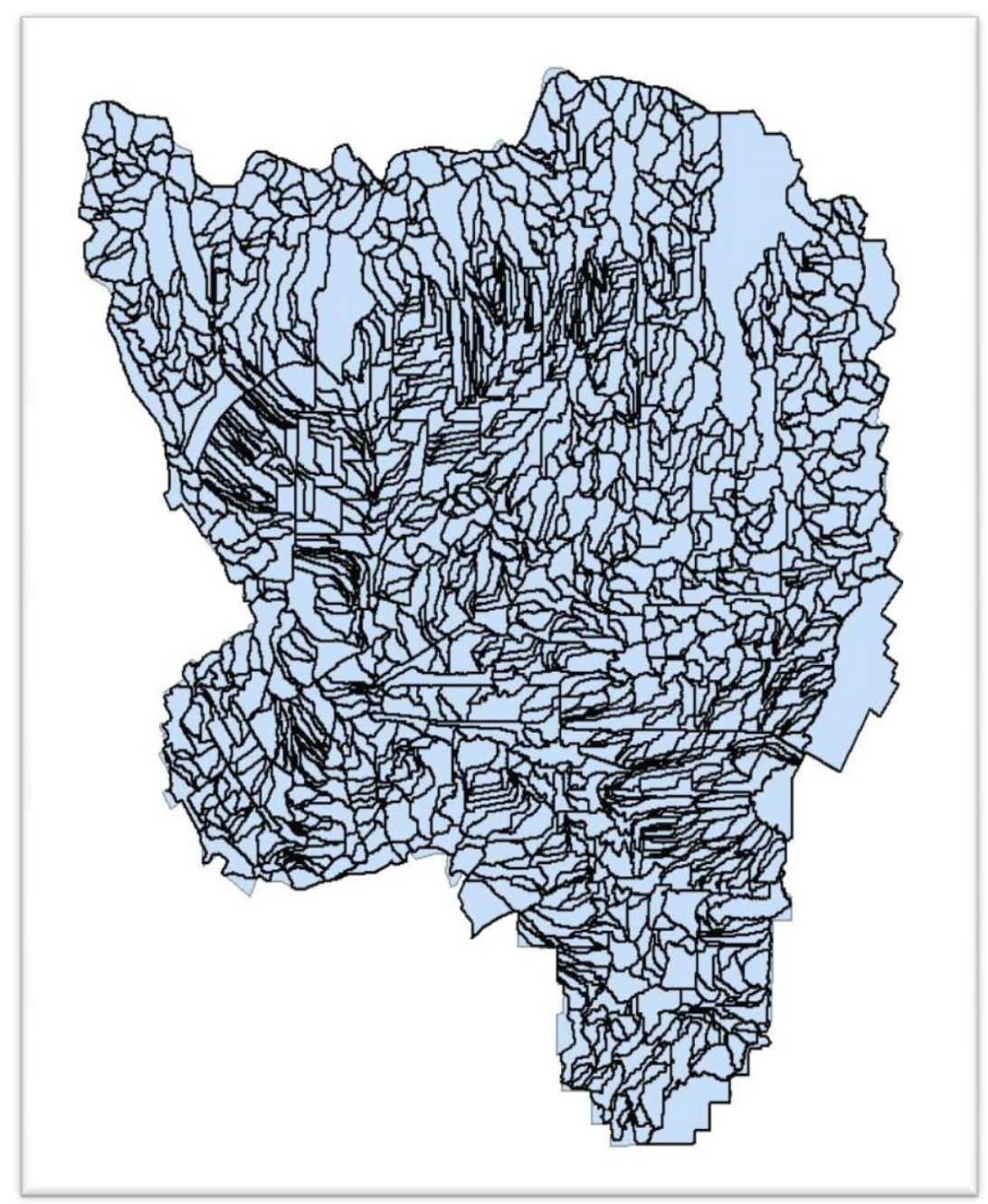

Figure 11: 1414-Subcatchment model, subcatchment delineations.

Table 5: Comparison of models

\begin{tabular}{|c|c|c|c|c|c|c|}
\hline $\begin{array}{c}\text { Model (Number } \\
\text { of } \\
\text { Subcatchments) }\end{array}$ & $\begin{array}{c}\text { Total } \\
\text { Area } \\
(\mathbf{a c r e s})\end{array}$ & $\begin{array}{c}\text { Average } \\
\text { Imperv. } \\
(\mathbf{\%})\end{array}$ & $\begin{array}{c}\text { Total } \\
\text { Width } \\
(\mathbf{f t})\end{array}$ & $\begin{array}{c}\text { Average } \\
\text { Slope } \\
(\boldsymbol{\%})\end{array}$ & $\begin{array}{c}\text { Total } \\
\text { Length } \\
(\mathbf{f t})\end{array}$ & $\begin{array}{c}\text { Average } \\
\text { Area } \\
\text { (Acre) }\end{array}$ \\
\hline 78 & 51,921 & 60 & 487,925 & 15 & 4,635 & 666 \\
\hline 244 & 52,904 & 58 & 881,476 & 15 & 2,614 & 217 \\
\hline 738 & 52,881 & 59 & $1,439,894$ & 14 & 1,600 & 72 \\
\hline 1414 & 52,971 & 58 & $1,973,816$ & 13 & 1,169 & 37 \\
\hline
\end{tabular}


From this comparison, it is apparent that the models are, for the most part, very similar. The total area modeled in each model is almost the same, as well as the average percent impervious and average slope. The parameters that differ are width and length. These parameters cannot be directly compared among the aggregation scales. The widths were calculated according to the Guo and Urbonas Shape Factor Method (Guo \& Urbonas, 2009) described above, and the lengths represent the longest water flowpaths in each subcatchment.

\section{$\underline{\text { BMP DESIGN METHOD }}$}

The sensitivity of spatial scale for the models was observed through the implementation of LIDs in a similar fashion to each model. Bioretention cells were sized and implemented into all subcatchments for each model in accordance to the City of Los Angeles Best Management Practices (BMP) Manual (City of Los Angeles, 2011). Bioretention cells (BRCs) are infiltration-based BMPs that retain water and reduce the stormwater runoff quantity, as well as work to improve the water quality of the runoff (Low Impact Development Center, 2007). 
The sizing of the BRCs was done according to the City of Los Angeles Best Management Practices (BMP) Manual (City of Los Angeles, 2011). The sizing of the BRCs utilized the guidelines summarized below, provided in the BMP Manual:

- The volume of runoff produced from a 0.75 -inch storm event;

- Infiltration systems, stormwater capture and use, high efficiency biofiltration/bioretention systems, or any combination of the above should be used to improve conditions;

- Underlying groundwater table is $>5$-ft from bottom of infiltration facility, infiltration rate of the saturated soil is $>0.3-\mathrm{in} / \mathrm{hr}$, and site is not located on a fill site or within a 50 -ft upgradient of a steep (20\% or greater) slope;

- All water must be discharged within 72 hours, deny vectors (any insect, anthropod, rodent, or other animal that is capable of harboring or transmitting a causative agent of human disease) access to standing water, and make the habitat less suitable for mosquito breeding. 48 hours is recommended for design as an added factor of safety.

Using the guidelines listed above and the design criteria provided in Table 19, in Appendix A, some further assumptions were necessary to complete the sizing design of the BRCs. The following assumptions were made in the design of the BRCs: 
- The ground slope at which the BRCs would be implemented was at a constant $1 \%$;

- A BRC would be designed on a " $\mathrm{ft}^{2}$ of BRC per acre of impervious land"; that way multiple BRCs could be implemented as needed into the subcatchments;

- A measured saturated hydraulic conductivity ( $\left.\mathrm{K}_{\text {sat,mesured }}\right)$, value of 0.6-in/hr was used for all soil types. 0.6 -in/hr was chosen as a worst-case, since most of the soil in the Ballona Creek watershed has a very low infiltration rate.

The design process starts by calculating the volume of water the BRC should capture, using Equation 5.

Equation 5:

$$
V_{\text {design }}=0.0625 * \text { Catchment Area }
$$

Where:

$$
\begin{aligned}
& \mathrm{V}_{\text {design }}=\text { volume of water the BRC will capture } \\
& \begin{aligned}
\text { Catchment Area } & \\
& =(0.9 * \text { Impervious Area })+[0.1 \\
& *(\text { Pervious Area }+ \text { Undeveloped Area })]
\end{aligned}
\end{aligned}
$$

Since it was assumed that only the impervious area was necessary for implementing BRCs, the second term in Equation 5 drops out of the catchment area calculation. Next the design infiltration rate can be determined using Equation 6 . 


\section{Equation 6:}

$$
K_{\text {sat,design }}=K_{\text {sat,mesaured }} / F S
$$

Where:

$$
\begin{aligned}
& \mathrm{K}_{\text {sat,design }}=\text { design infiltration rate } \\
& \mathrm{K}_{\text {sat,measured }}=\text { infiltration rate measured in the field (0.6-in/hr as an assumption) } \\
& \mathrm{FS}=\text { factor of safety (3, in accordance with Table 19) }
\end{aligned}
$$

The maximum depth of runoff that can be infiltrated in the allotted time (48-hours, according to Table 19) was calculated using Equation 7.

\section{Equation 7:}

$$
D_{\text {eff }}=T * K_{\text {sat,design }} / 12 * R_{b}
$$

Where:

$D_{\text {eff }}=$ maximum depth of runoff that can be infiltrated

$\mathrm{T}=$ drawdown time (48-hours)

$\mathrm{K}_{\text {sat,design }}=$ design infiltration rate

$\mathrm{R}_{\mathrm{b}}=$ void ratio (0.4 for gap graded gravel, 0.3 for amended soil; 0.3 assumed for all BRCs)

The minimum BRC surface area was calculated using Equation 8.

Equation 8:

$$
A_{\text {min }}=V_{\text {design }} / D_{\text {eff }}
$$

Where: 


$$
\begin{aligned}
& A_{\text {min }}=\text { minimum surface area of BRC } \\
& V_{\text {design }}=\text { volume of water the BRC captures } \\
& D_{\text {eff }}=\text { maximum depth of runoff that can be infiltrated }
\end{aligned}
$$

The depth of the media required for the BRC was calculated using Equation 9.

\section{Equation 9:}

$$
D_{\text {media }}=V_{\text {design }}-\left(K_{\text {sat,design }} * T * A_{\text {min }}\right) / 12 / A_{\text {min }} * R_{b}
$$

Where:

$$
\begin{aligned}
& \mathrm{D}_{\text {media }}=\text { depth of media } \\
& \mathrm{V}_{\text {design }}=\text { volume of water the BRC captures } \\
& \mathrm{K}_{\text {sat,design }}=\text { design infiltration rate } \\
& \mathrm{T}=\text { drawdown time (48-hours) } \\
& \mathrm{A}_{\text {min }}=\text { minimum surface area of BRC } \\
& \mathrm{R}_{\mathrm{b}}=\text { void ration }(0.4 \text { for gap graded gravel, } 0.3 \text { for amended soil; } 0.3 \text { assumed for } \\
& \text { all BRCs) }
\end{aligned}
$$

The procedures described above were used to calculate a single area of BRC $\left(\mathrm{ft}^{2}\right)$ necessary to capture 0.75 -in of rain on a 1-acre of impervious land to be $918.8-\mathrm{ft}^{2}$. By calculating a single area or BRC necessary per acre, this area could be multiplied by the amount of impervious area in each subcatchment. The BRC design is summarized below in Table 6. 
Table 6: BRC Design Summary Table

\begin{tabular}{|c|c|c|c|c|c|c|c|c|}
\hline $\begin{array}{c}\text { Water } \\
\text { Depth (in) }\end{array}$ & $\begin{array}{c}\mathbf{V}_{\text {design }} \\
\left(\mathbf{f t}^{\mathbf{3}}\right)\end{array}$ & $\begin{array}{c}\mathbf{K}_{\text {sat,measured }} \\
(\mathbf{i n} / \mathbf{h r})\end{array}$ & $\begin{array}{c}\mathbf{K}_{\text {sat,design }} \\
(\mathbf{i n} / \mathbf{h r})\end{array}$ & $\begin{array}{c}\mathbf{D}_{\text {eff }} \\
(\mathbf{f t})\end{array}$ & $\begin{array}{c}\mathbf{T} \\
(\mathbf{h r})\end{array}$ & $\begin{array}{c}\mathbf{A}_{\text {min }} \\
\left(\mathbf{f t}^{2}\right)\end{array}$ & $\mathbf{R}_{\mathbf{b}}$ & $\begin{array}{c}\mathbf{D}_{\text {media }} \\
(\mathbf{i n})\end{array}$ \\
\hline 0.75 & 2450.25 & 0.6 & 0.2 & 2.667 & 48 & 918.8 & 0.3 & 74.667 \\
\hline
\end{tabular}

\section{BIORETENTION CELL IMPLEMENTATION}

As previously explained, the area of BRC needed was calculated on a per acre basis. The following assumptions were made in order to implement the BRCs into the SWMM models:

- Only $25 \%$ of the impervious area of each subcatchment can be devoted to the BRCs; since the watershed is highly urbanized, it is impossible to believe that all of the impervious area could be treated by BRCs;

- Each BRC would have the a surface area of $20-\mathrm{ft}^{2}$ (4-ft wide by 5 - $\mathrm{ft}$ long);

The calculations described in the previous section and summarized in Table 6 were implemented into SWMM as a single LID Bioretention Cell. Once the LID feature was created in SWMM, each subcatchment was assigned a number of these BRCs based on the area of impervious land in each subcatchment, using the assumption that only $25 \%$ of the impervious land was available for BRC use. 
Every subcatchment in the models was modified by adding in the BRCs, regardless of the location or properties of the subcatchment. This most likely is not practical, as some subcatchments cannot realistically devote $25 \%$ of their impervious area to BRC use, but rather a way to implement the LID feature universally to the different subcatchment aggregations keeping the spatial scale as the only varying parameter. The runoff quantity at the outlet of Ballona Creek will be compared for all the four original model simulations, without the BRCs implemented, and compared to the four new models with the BRCs.

\section{MODEL CALIBRATION EFFICIENCY CRITERIUM}

Each model was originally parameterized using the HEC-GeoHMS tools described previously. These parameters were the starting point for the modeling, and would be adjusted to optimize the models' performance in relation to observed data. Optimization is the process of universally adjusting the original parameters to better match observed data. The HEC-GeoHMS tools gave the models a good place to start, and then the parameters can be universally adjusted (by a determined percentage) to match observed as best as possible. It is important to note that this parameter optimization is not perfect, but provides a valuable tool in model calibration (Scharffenberg \& Flemming, 2009).

This optimization process begins with initial parameters established from the methods

described previously, and adjusts them to match observed streamflow data obtained from 
the Los Angeles County Department of Public Works (County of Los Angeles, 2013). This observed streamflow data, was collected from the same types of equipment as the rainfall data (Amenu, 2011). For this study, the models were calibrated to continuous (long-term) streamflow data ranging from October 1, 2009 (10/01/2009) to March 31, $2010(03 / 31 / 2010)$. Calibrating to continuous streamflow data gives more accurate results in terms of total runoff volume (Mancipe-Munoz, Buchberger, Suidan, \& Lu, 2014). When calibrating watershed models, any number of parameters can be chosen to be a part of the calibration. For this study five (5) parameters where chosen; subcatchment width, slope, percent impervious, percent routed, and curve number.

The subcatchments' widths and slopes were calculated using the Guo and Urbonas Shape Factor Method (Guo \& Urbonas, 2009) described previously. These parameters were chosen to be a part of the calibration to see how the Shape Factor Method performed as an initial estimation for these parameters. Curve numbers were calculated for each subcatchment using the HEC-GeoHMS tools, and took into account the entire subcatchment, pervious and impervious. SWMM uses curve number to only represent the pervious area of the subcatchment, so it was expected that the calibration would reduce the curve numbers for each subcatchment down to model only the pervious area. Because of this change, the percent impervious of each subcatchment was also chosen to be a part of the calibration. The percent routed is the amount of runoff routed between subareas. This was initially assumed to be the default value of $100 \%$, but was calibrated with the expectation to be substantially reduced, since not all impervious areas in a subwatershed are expected to be directly connected to an outlet. 
Performance of the calibrated models was evaluated using four goodness-of-fit criteria, or efficiency criteria. Efficiency criteria, are derived from the residual (error) between the observed data and simulated calculations (Muleta M. , 2012). For this study the efficiency criteria used were the Root Mean Square Error (RMSE), Mean Absolute Error (MAE), Nash-Sutcliffe Efficiency (NSE), and Percent Bias (\%Bias).

The Root Mean Square Error (RMSE) ranges from zero (ideal model) to positive infinity (worst model), and is biased toward peak flows (Muleta M., 2012). RMSE is shown in Equation 10.

Equation 10:

$$
R M S E=\sqrt{\frac{1}{N} \sum_{i=1}^{N}\left(S_{i}-O_{i}\right)^{2}}
$$

Where:

$$
\begin{aligned}
& \text { RMSE = root mean square error } \\
& \mathrm{N}=\text { total number of observations } \\
& \mathrm{S}=\text { model simulated output } \\
& \mathrm{O}=\text { observed hydrologic variable }
\end{aligned}
$$

The Mean Absolute Error (MAE) is expected to be less sensitive to high flows and, therefore evaluating model performance more evenly. MAE ranges from zero (ideal model) to positive infinity (worst model) (Muleta M. , 2012). MAE is shown in Equation 11. 


\section{Equation 11:}

$$
M A E=\frac{1}{N} \sum_{i=1}^{N}\left|S_{i}-O_{i}\right|
$$

Where:

$$
\begin{aligned}
& \text { MAE = mean absolute error } \\
& \mathrm{N}=\text { total number of observations } \\
& \mathrm{S}=\text { model simulated output } \\
& \mathrm{O}=\text { observed hydrologic variable }
\end{aligned}
$$

The Nash-Sutcliffe Efficiency (NSE) uses a benchmark mean observed value to determine if the model is a good predictor. NSE ranges from negative infinity (worst model) to one (perfect model). A NSE value greater than zero implies that the observed mean is a good predictor, where a value less than zero means the model is a worse predictor than the mean value (Muleta M., 2012). NSE is shown in Equation 12.

Equation 12:

$$
N S E=1-\sum_{i=1}^{N}\left(S_{i}-O_{i}\right)^{2} / \sum_{i=1}^{N}\left(O_{i}-O_{\text {mean }}\right)^{2}
$$

Where:

$$
\begin{aligned}
& \text { NSE = Nash-Sutcliffe efficiency } \\
& \mathrm{N}=\text { total number of observations } \\
& \mathrm{S}=\text { model simulated output } \\
& \mathrm{O}=\text { observed hydrologic variable } \\
& \mathrm{O}_{\text {mean }}=\text { mean of the observations that the NS uses as a benchmark against which } \\
& \text { performance of the hydrologic model is compared }
\end{aligned}
$$


Percent Bias (\%Bias) describes whether the model simulates an over- or underestimate of the observed data. \%Bias ranges from negative infinity to positive infinity (Muleta M. , 2012). \%Bias is shown in Equation 13.

Equation 13:

$$
\% \text { Bias }=100 * \sum_{i=1}^{N}\left(S_{i}-O_{i}\right) / \sum_{i-1}^{N} O_{i}
$$

Where:

$$
\begin{aligned}
& \% \text { Bias = percent bias } \\
& \mathrm{N}=\text { total number of observations } \\
& \mathrm{S}=\text { model simulated output } \\
& \mathrm{O}=\text { observed hydrologic variable }
\end{aligned}
$$




\section{CHAPTER 4: CALIBRATION AND VALIDATION RESULTS AND DISCUSSION}

The calibration and validation results from the four efficiency criteria described above will be presented in this chapter.

\section{MODEL CALIBRATION}

All of the calibration results were satisfactory for use as working watershed models, and can be seen in Table 7 .

Table 7: Calibration efficiency value results

\begin{tabular}{|c|c|c|c|c|}
\hline & \multicolumn{4}{|c|}{ Efficiency Values - Calibration } \\
\hline Model & RMSE (cfs) & MAE (cfs) & NSE & \%Bias \\
\hline 78 & 179.471 & 29.855 & 0.91 & -9.612 \\
\hline 244 & 154.151 & 27.376 & 0.934 & -7.391 \\
\hline 738 & 174.86 & 29.883 & 0.915 & -6.21 \\
\hline 1414 & 157.773 & 28.294 & 0.931 & -7.859 \\
\hline
\end{tabular}

Based on these calibration results, each of the five parameters was assigned a percentage to be modified to match the observed data as well as possible. The modification percentages obtained for each model can be seen in Table 8 . 
Table 8: Calibration modification percentages

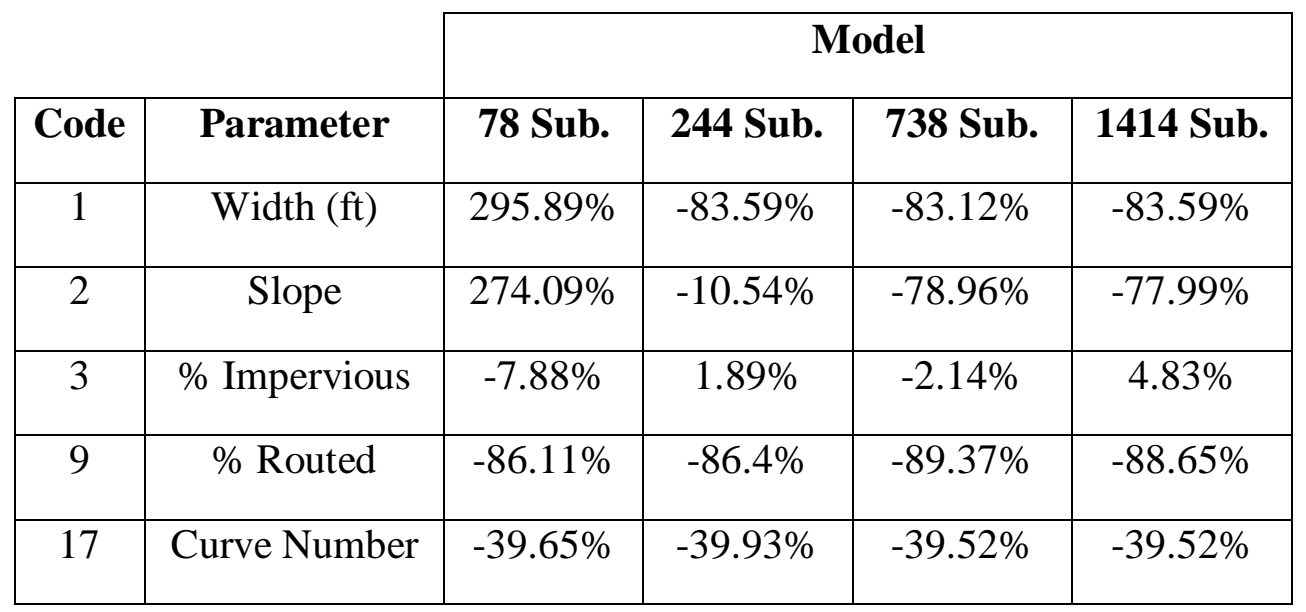

Applying these calibration modification factors to each model allowed the observed and simulated streamflow to be plotted and the effectiveness of the calibration seen visually. Time series plots of the observed and simulated data for calibration, zoomed in to show one week can be seen in Figure 12 through Figure 15. Scatter plots of the observed and simulated results can be seen in Figure 16 through Figure 19. Time series plots of the observed and simulate flows for the entire calibration period are provided in Appendix B. 


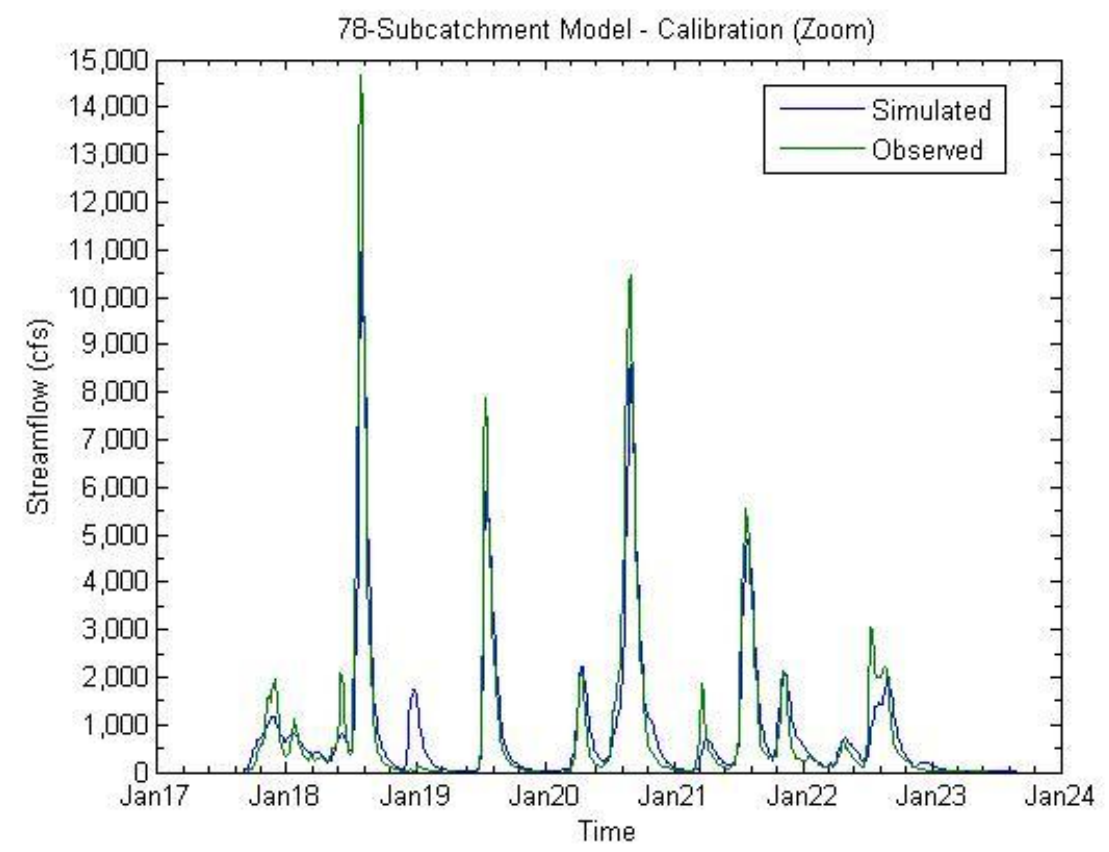

Figure 12: 78-Subcatchment model, calibration time series, zoomed-in. 


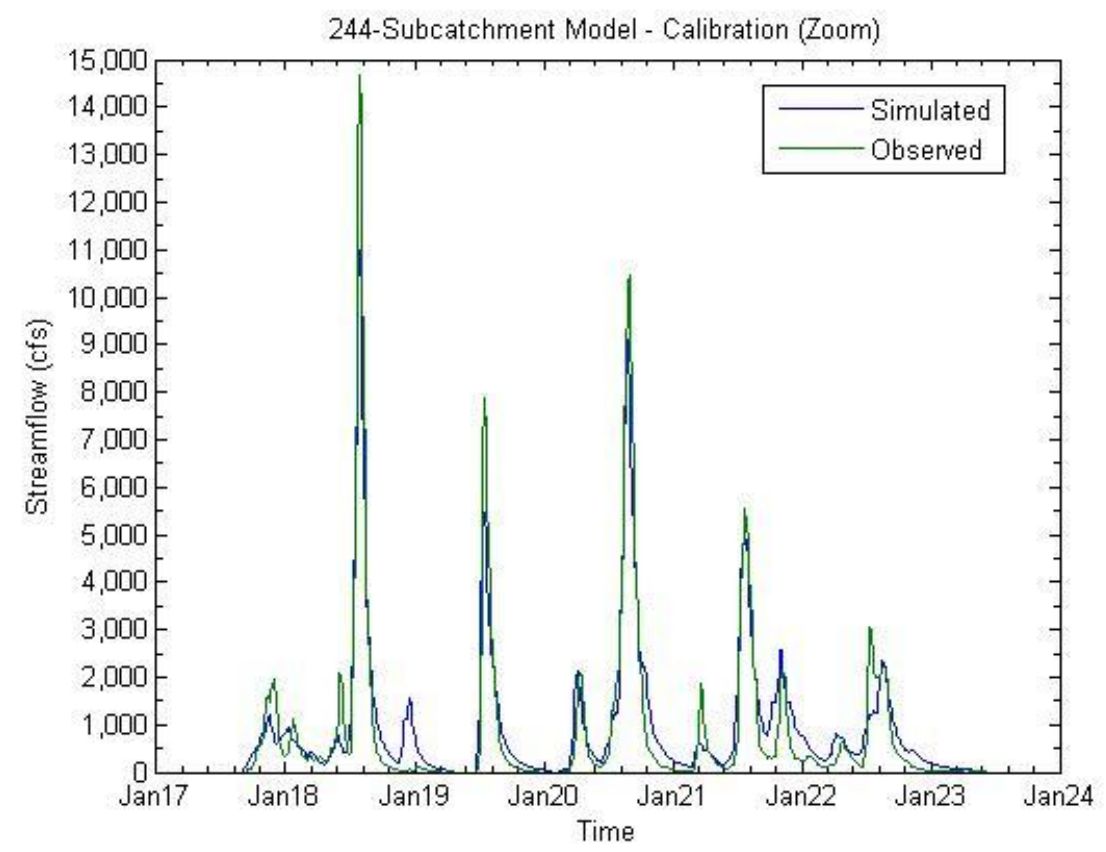

Figure 13: 244-Subcatchment model, calibration time series, zoomed-in.

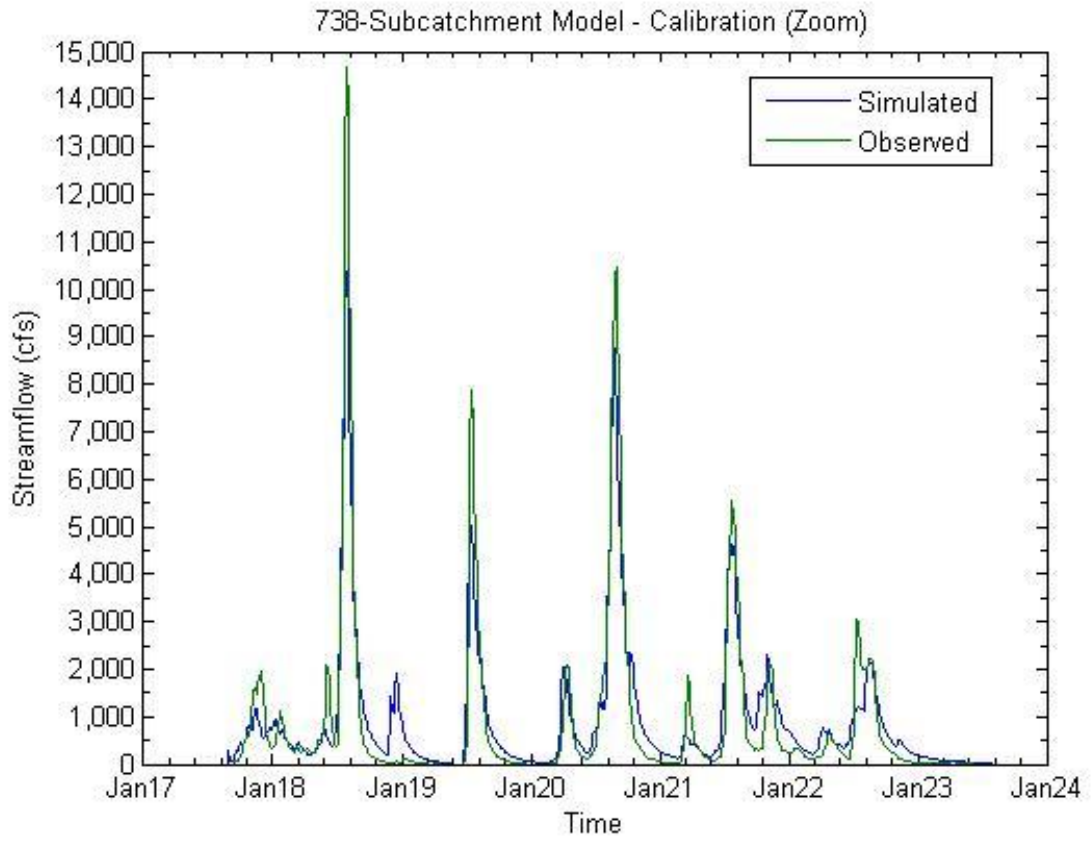

Figure 14: 738-Subcatchment model, calibration time series, zoomed-in. 


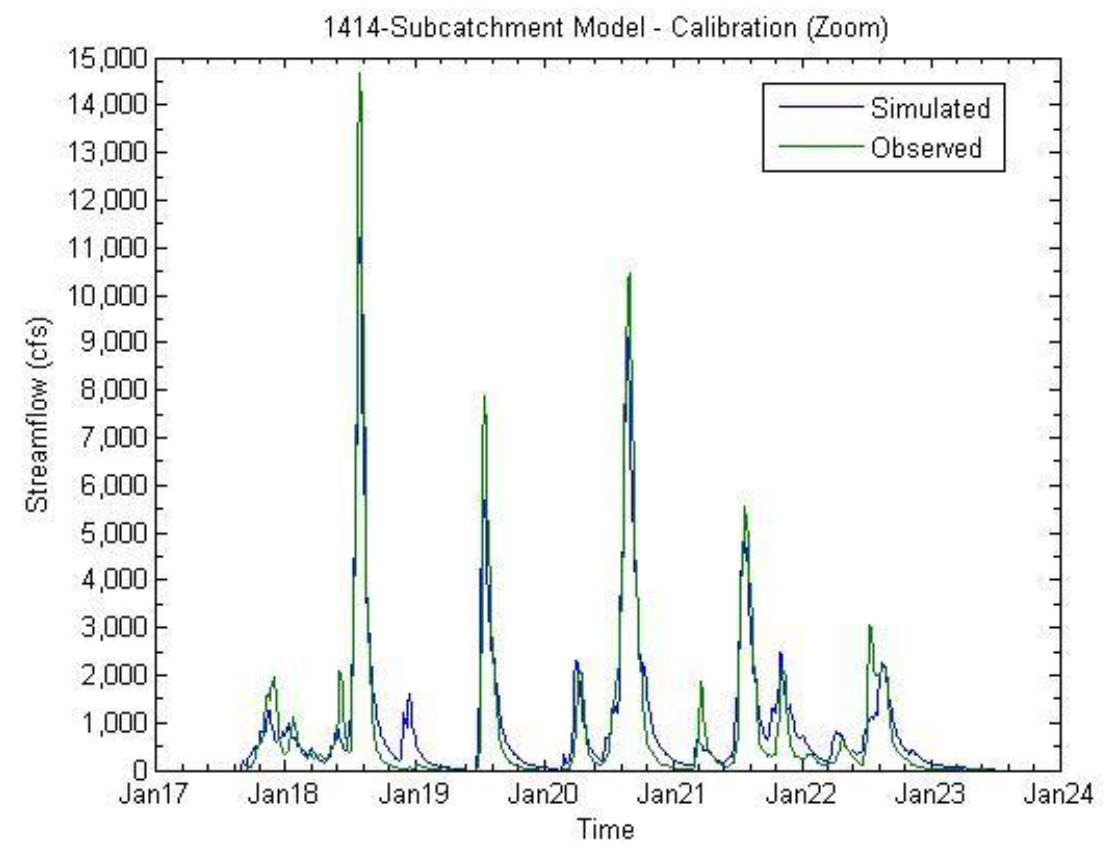

Figure 15: 1414-Subcatchment model, calibration time series, zoomed-in.

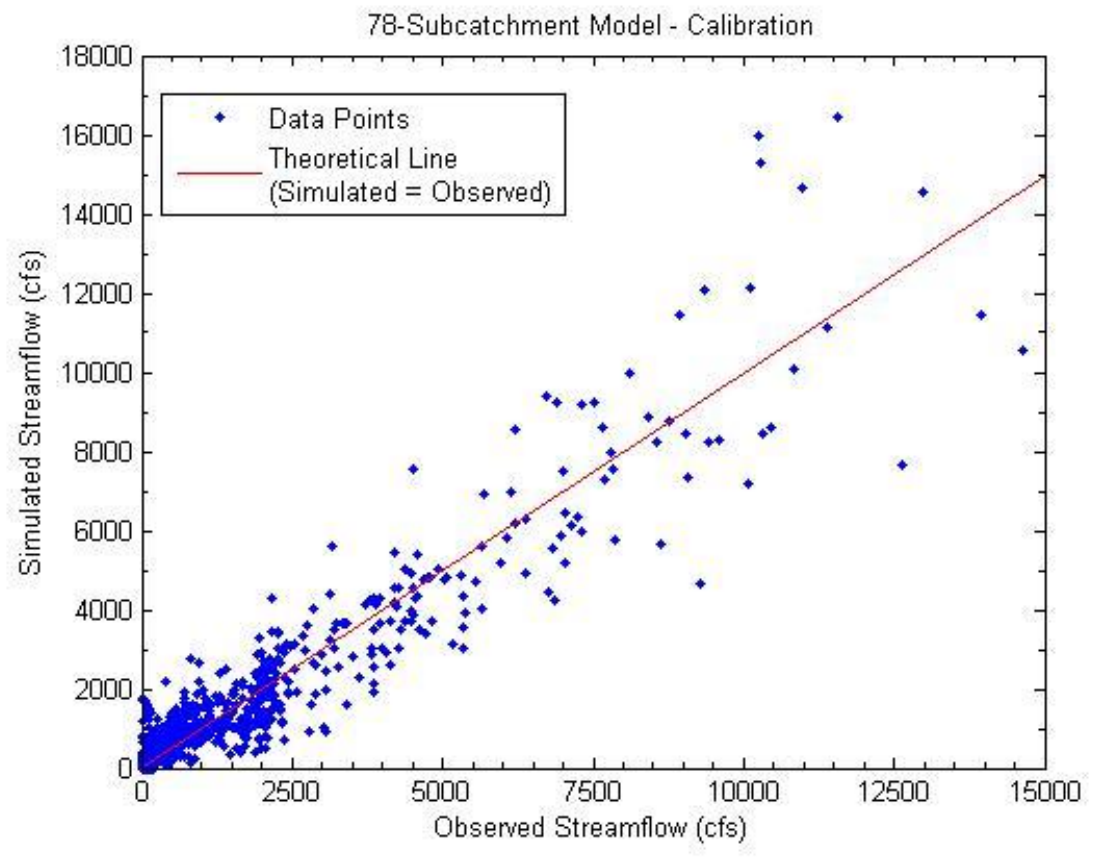

Figure 16: 78-Subcatchment model, calibration scatter plot. 


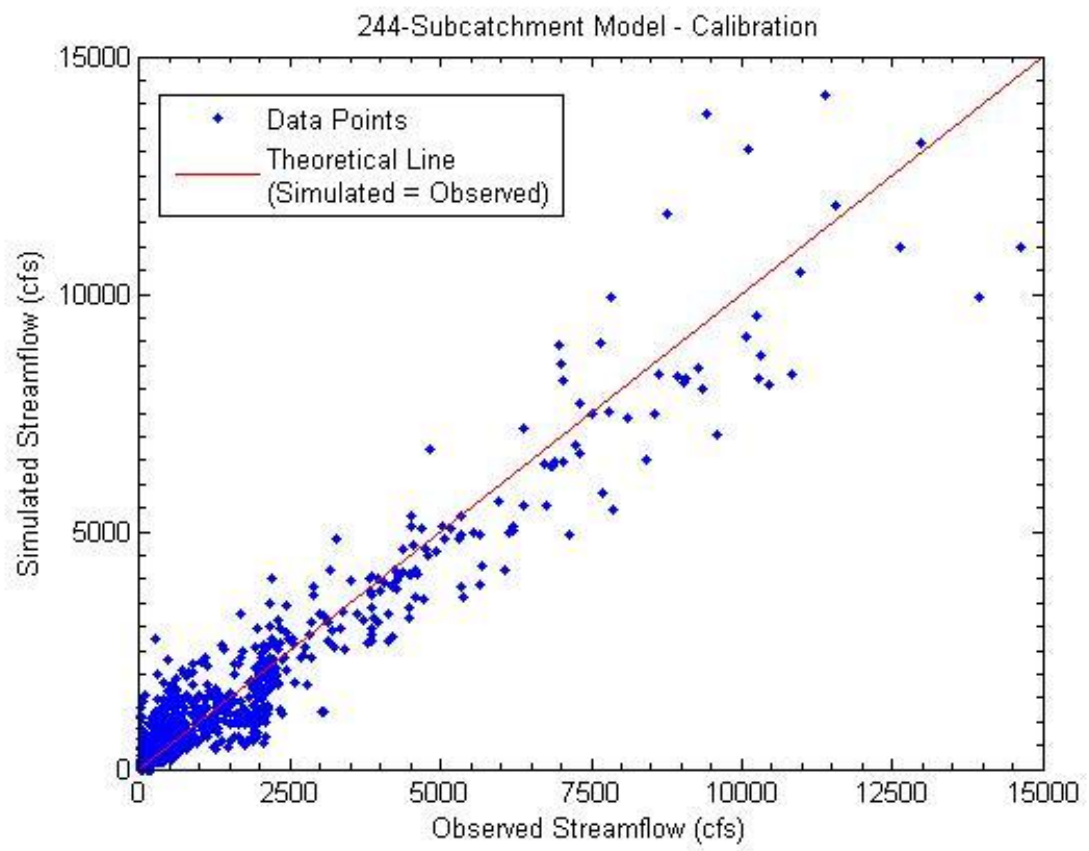

Figure 17: 244-Subcatchment model, calibration scatter plot.

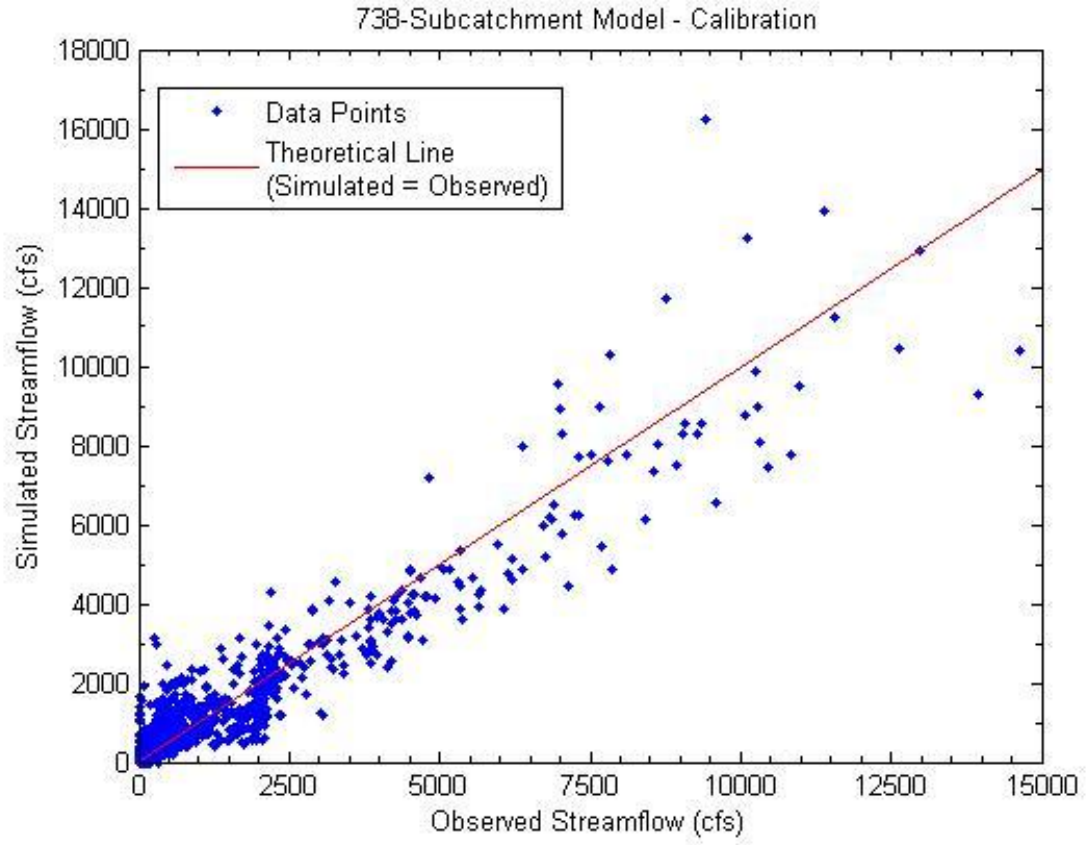

Figure 18: 738-Subcatchment model, calibration scatter plot. 


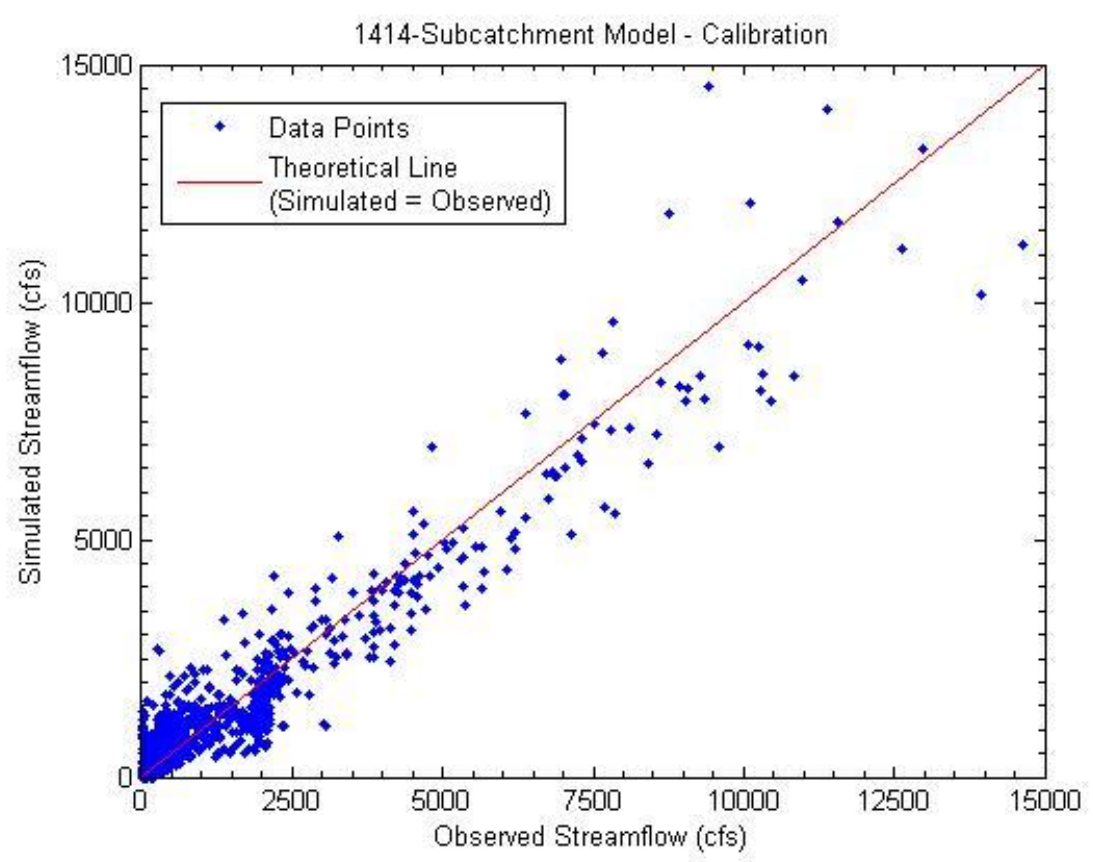

Figure 19: 1414-Subcatchment model, calibration scatter plot.

\section{MODEL VALIDATION}

Validation is the process of using a calibrated model to simulate another set of data not used in the calibration. Validation can be considered as the most important process for establishing reliable and effective models (Nix, 1994). For this study the models were all validated over a continuous (long-term) simulation from October 1, 2005 (10/01/2005) to March 31, 2006 (03/31/2006). The same efficiency criteria used in calibration were calculated for the validation period, and shown in Table 9. All of the validation results were sufficient for use as a working watershed models. 
Table 9: Validation efficiency value results

\begin{tabular}{|c|c|c|c|c|}
\cline { 2 - 5 } \multicolumn{1}{c|}{} & \multicolumn{4}{c|}{ Efficiency Values - Validation } \\
\hline Model & RMSE (cfs) & MAE (cfs) & NSE & \% Bias \\
\hline 78 & 287.264 & 41.513 & 0.703 & 20.555 \\
\hline 244 & 255.378 & 32.971 & 0.817 & 26.837 \\
\hline 738 & 240.103 & 34.672 & 0.792 & 28.247 \\
\hline 1414 & 216.606 & 32.8 & 0.831 & 24.051 \\
\hline
\end{tabular}

Time series plots of the observed and simulated data for validation, showing one week, can be seen in Figure 20 through Figure 23. Scatter plots of the observed and simulated results can be seen in Figure 24 through Figure 27. Time series plots of the observed and simulate flows for the entire validation period are provided in Appendix B.

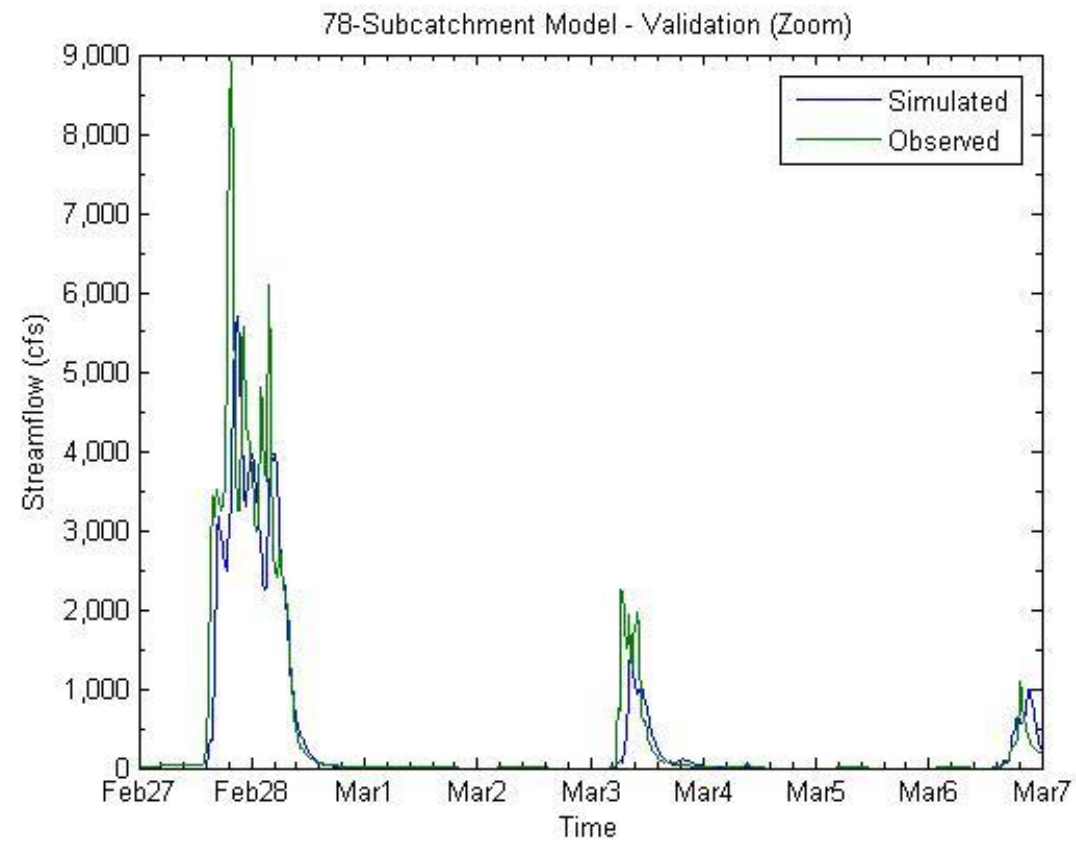

Figure 20: 78-Subcatchment model, validation time series, zoomed-in. 


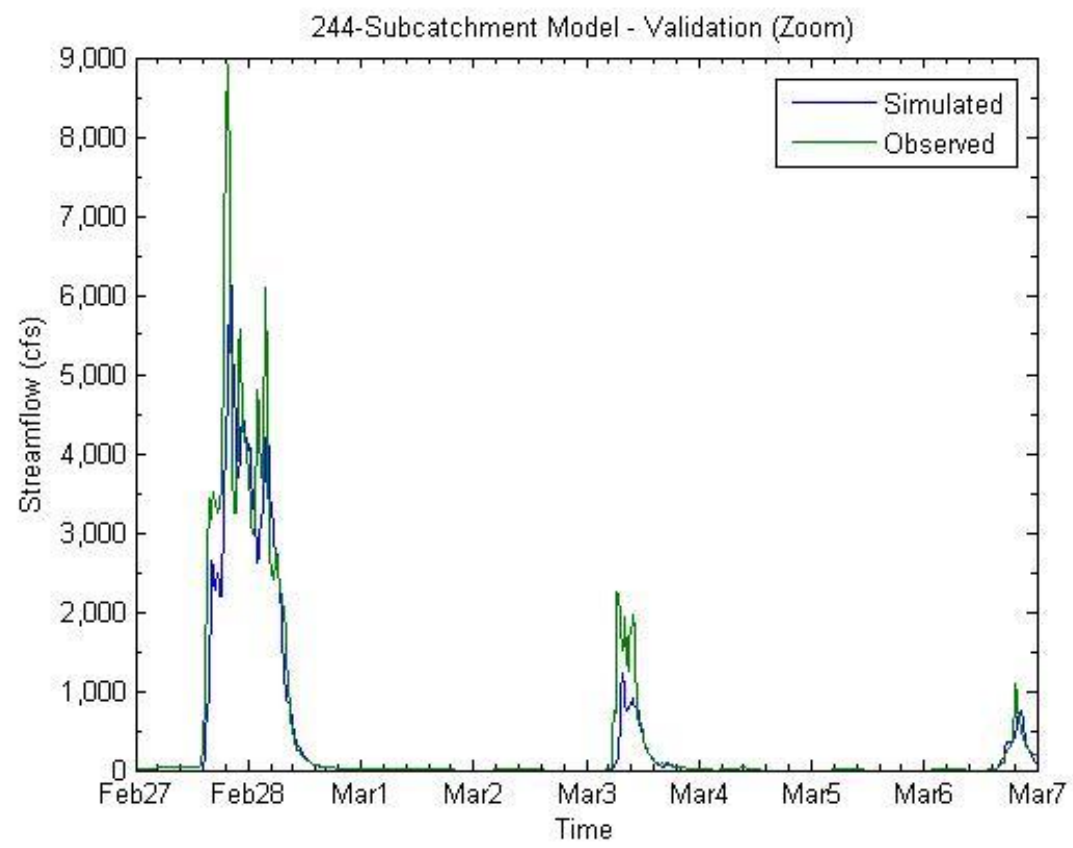

Figure 21: 244-Subcatchment model, validation time series, zoomed-in.

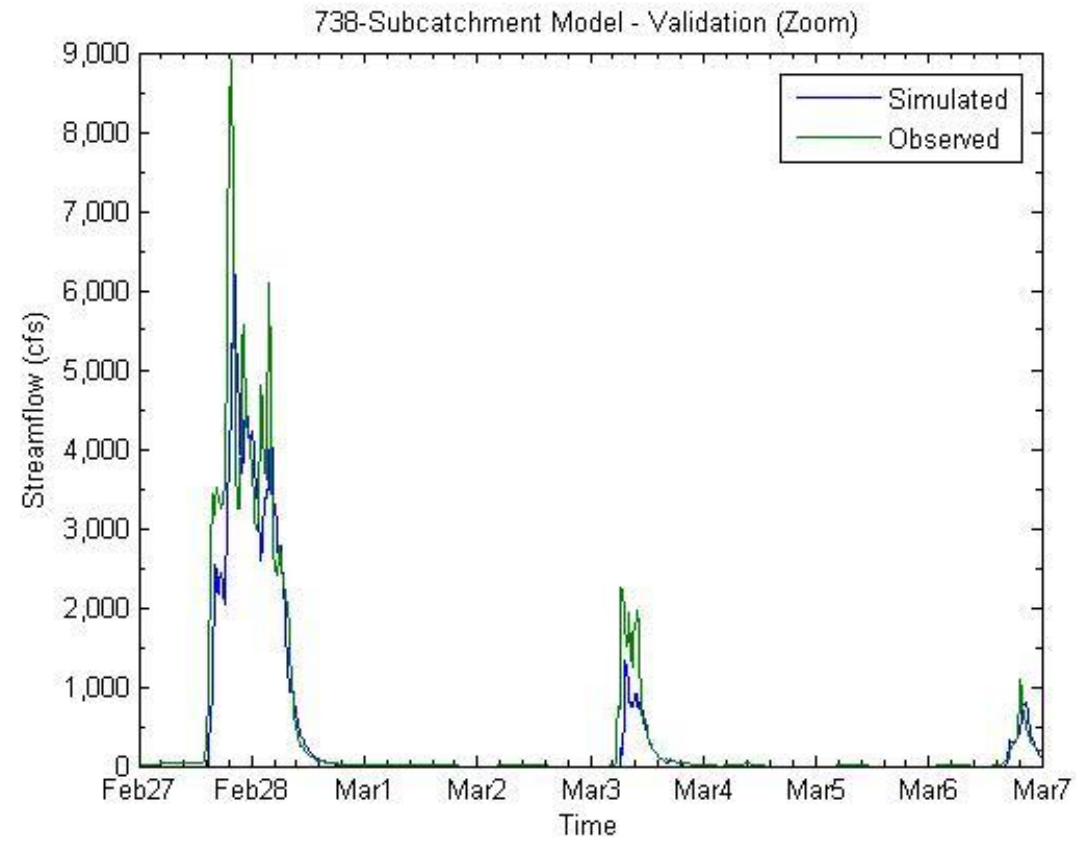

Figure 22: 738-Subcatchment model, validation time series, zoomed-in. 


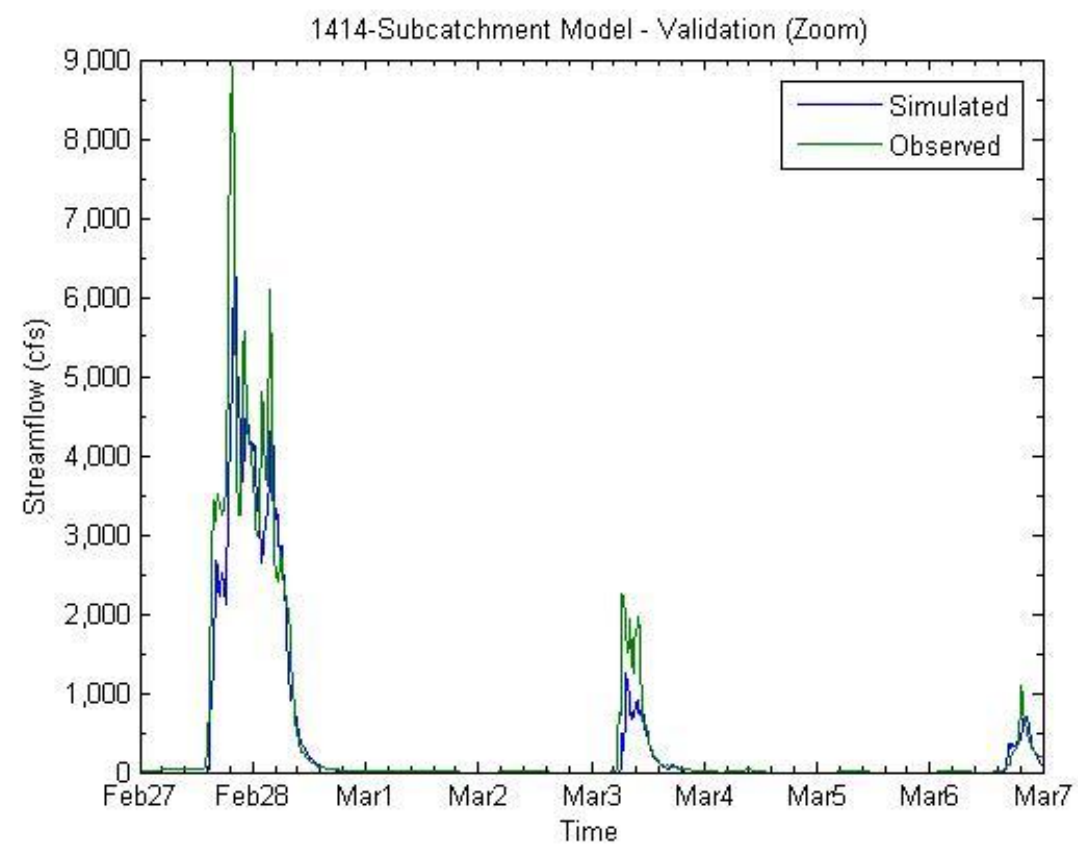

Figure 23: 1414-Subcatchment model, validation time series, zoomed-in.

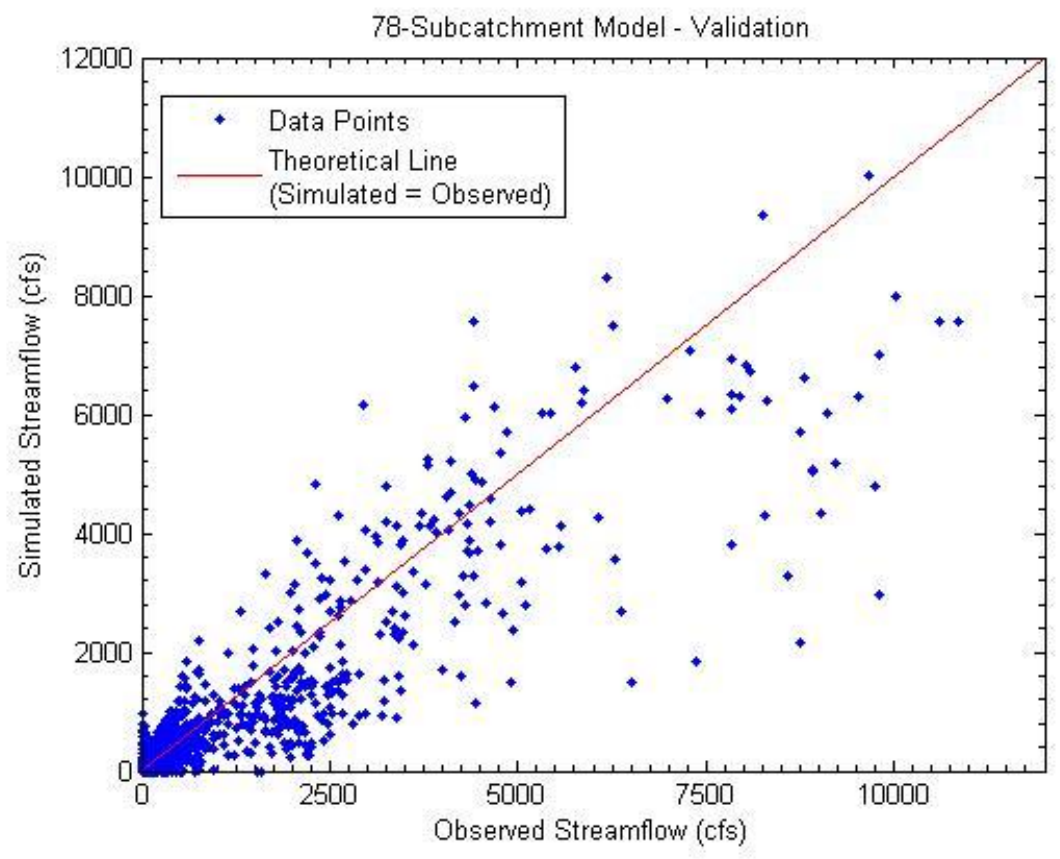

Figure 24: 78-Subcatchment model, validation scatter plot. 


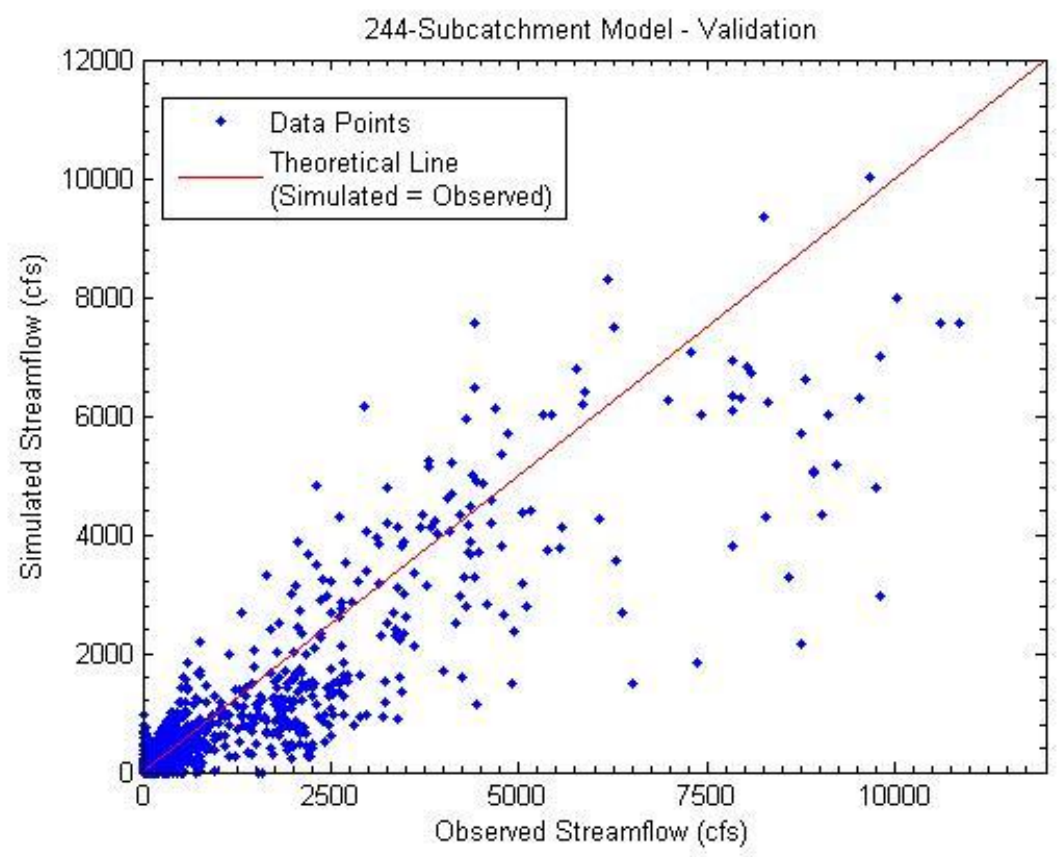

Figure 25: 244-Subcatchment model, validation scatter plot.

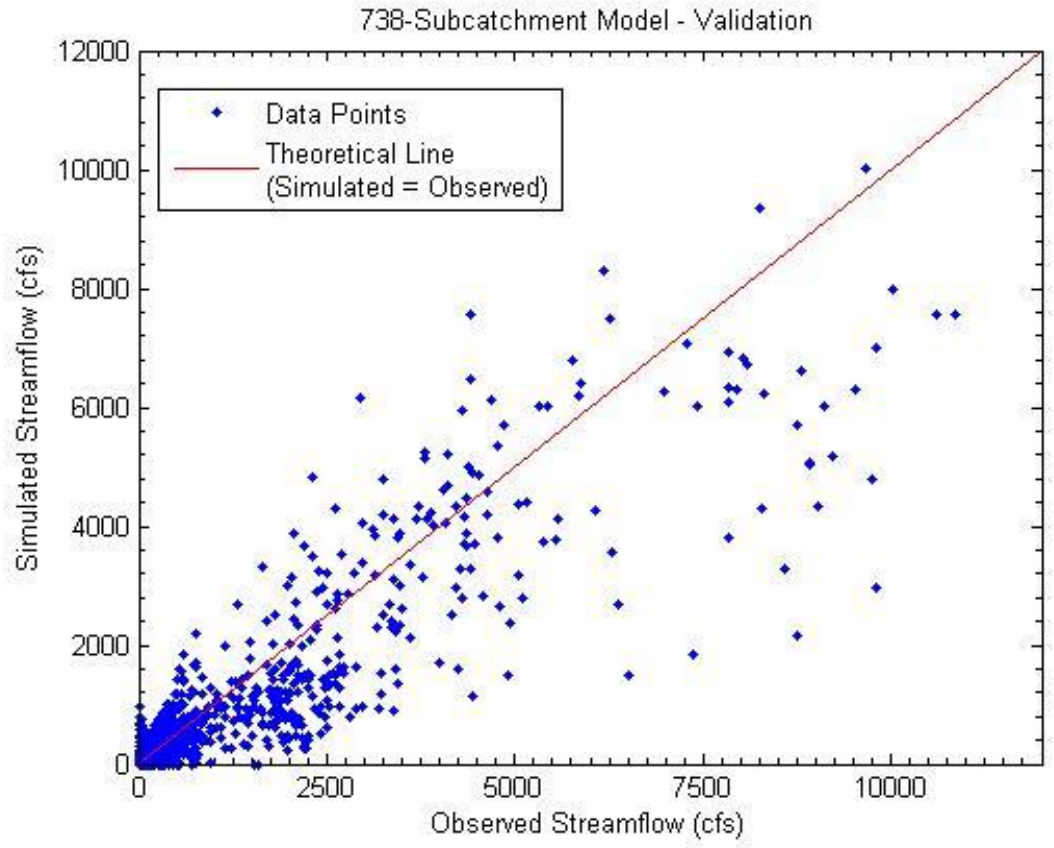

Figure 26: 738-Subcatchment model, validation scatter plot. 


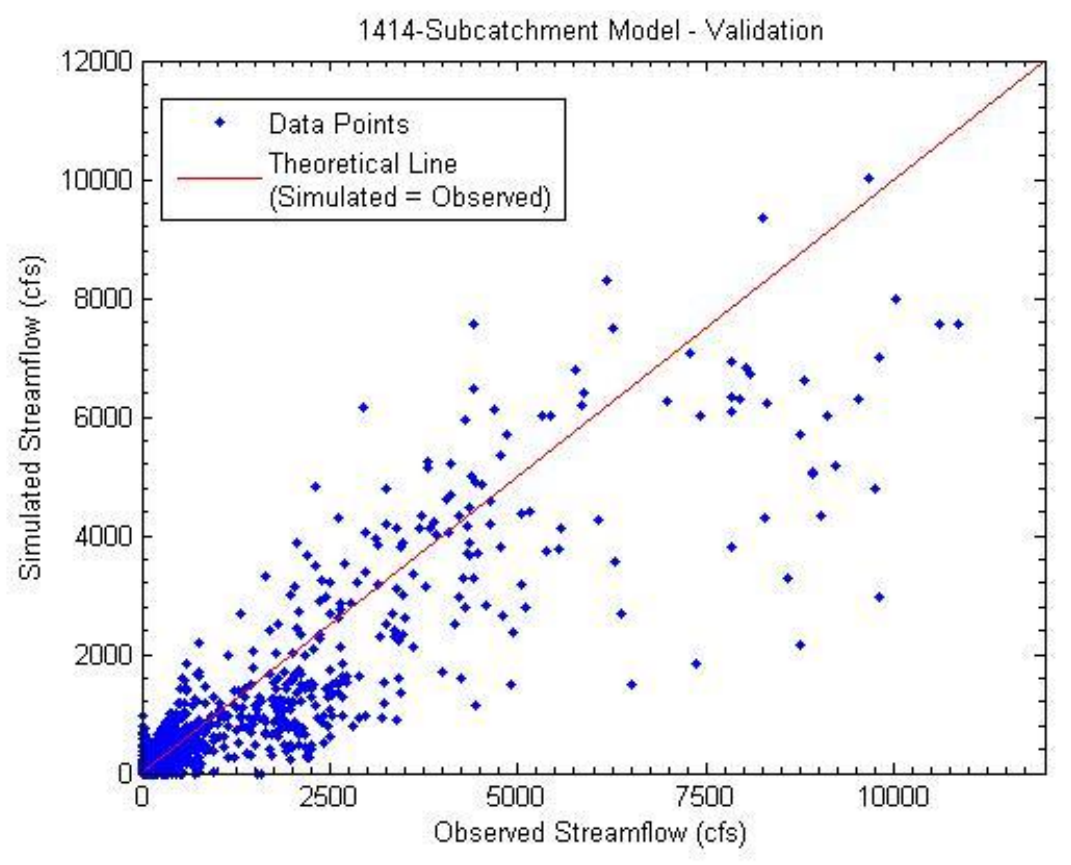

Figure 27: 1414-Subcatchment model, validation scatter plot.

\section{BIORETENTION CELL CALIBRATION}

The methods described above were used to calibrate and validate the models for runoff quantity. It was also desired that performance of the bioretention cells (BRCs) designed is representative of observed hydrologic performance for the BRCs already implemented. Performance data for BRCs was difficult to obtain. A report from the International Stormwater BMP Database (Geosyntec Consultants, Inc., 2012) that documented BRC performance data for many BRCs on the east coast of the United States was used for this study. This was the most reliable data available to calibrate the BRC design with observed data. Reliable hydrologic performance data for BRCs in southern California or the western United States was not available. 
Using the same modeling techniques in SWMM as previously described, the BRCs in the BMP Database Addendum that most closely resemble the BRC designed for this research, were modeled using as much information as was provided in the report. These BRCs were modeled using the same continuous rainfall data as the Ballona Creek watershed models were calibrated over, as well as the 1-, 2-, 5-, and 10-year storm events as found from the NOAA's National Weather Service Atlas 14 for Ballona Creek Watershed (http://hdsc.nws.noaa.gov/hdsc/pfds/pfds_map_cont.html?bkmrk=ca) (NOAA, 2014). These rainfall depths can be seen in Table 10.

Table 10: Storm event rainfall depths.

\begin{tabular}{|c|c|c|c|c|}
\cline { 2 - 5 } \multicolumn{1}{c|}{} & \multicolumn{4}{c|}{ Rainfall Depth (in) } \\
\hline Rain Gage & 1-yr, 24-hr & 2-yr, 24-hr & 5-yr, 24-hr & 10-yr, 24-hr \\
\hline Hollywood_312 & 2.38 & 3.18 & 4.27 & 5.21 \\
\hline Swattle_370 & 2 & 2.63 & 3.48 & 4.2 \\
\hline USC_375 & 2 & 2.63 & 3.46 & 4.14 \\
\hline
\end{tabular}

A major assumption for the $\mathrm{BRC}$ calibration is the $\mathrm{BRC}$ acting "like new" for the entirety of the simulation period. This is assuming that the BRC is properly maintained, and maintains perfect condition. This assumption must be made, as there is no data on longterm performance of the BRCs available from the BMP database.

Table 11 shows the performances as reported in the BMP Database Addendum as well as by the SWMM model. It can be seen that the SWMM modeled performance of the BRCs satisfactorily as reported in the report. The models were compared based on total inflow and outflow volumes into and out of the BRCs. With the lack of any more data, this was 
taken as successful calibration and validation of the BRC design for the Ballona Creek watershed models.

Table 11: Comparison of Observed and Modeled BRC Performances.

\begin{tabular}{|c|c|c|c|c|c|c|}
\hline $\begin{array}{c}\text { BMP Name } \\
\text { (Location) }\end{array}$ & $\begin{array}{c}\text { 25th-\% } \\
\text { Vol Red }\end{array}$ & $\begin{array}{c}\text { Median } \\
\text { Vol Red }\end{array}$ & $\begin{array}{c}\text { 75th-\% } \\
\text { Vol Red }\end{array}$ & $\begin{array}{c}\text { Average } \\
\text { Vol Red }\end{array}$ & $\begin{array}{c}\text { Cumulative } \\
\text { Vol Red }\end{array}$ & $\begin{array}{c}\text { Modeled } \\
\text { Vol Red }\end{array}$ \\
\hline $\begin{array}{c}\text { BRC_A } \\
\text { (NC) }\end{array}$ & 27 & 42 & 50 & 43 & 31 & 31 \\
\hline $\begin{array}{c}\text { BRC_B } \\
\text { (NC) }\end{array}$ & 36 & 58 & 90 & 58 & 42 & 36 \\
\hline $\begin{array}{c}\text { North cell } \\
\text { (NC) }\end{array}$ & 7 & 30 & 43 & 19 & 11 & 32 \\
\hline G2 (NC) & 80 & 97 & 100 & 84 & 55 & 51 \\
\hline $\begin{array}{c}\text { Hal } \\
\text { Marshall } \\
\text { Bioretention } \\
\text { Cell (NC) }\end{array}$ & 36 & 62 & 65 & 51 & 60 & 51 \\
\hline L1 (NC) & 22 & 64 & 72 & 52 & 28 & 32 \\
\hline L2 (NC) & 20 & 40 & 56 & 34 & 20 & 33 \\
\hline $\begin{array}{c}\text { Pump } \\
\text { House Rain } \\
\text { Garden } \\
\text { Prairie (WI) }\end{array}$ & 100 & 100 & 100 & 100 & 99 & 100 \\
\hline $\begin{array}{c}\text { Pump } \\
\text { House Rain } \\
\text { Garden Turf } \\
\text { (WI) }\end{array}$ & 100 & 100 & 100 & 100 & 99 & 100 \\
\hline $\begin{array}{c}\text { Owen Rain } \\
\text { Garden } \\
\text { Prairie (WI) }\end{array}$ & 100 & 100 & 100 & 100 & 100 & 97 \\
\hline $\begin{array}{c}\text { Owen Rain } \\
\text { Garden Turf } \\
\text { (WI) }\end{array}$ & 100 & 100 & 100 & 100 & 100 & 98 \\
\hline $\begin{array}{c}\text { Traffic } \\
\text { Island (PA) }\end{array}$ & 67 & 100 & 100 & 82 & 53 & 47 \\
\hline
\end{tabular}

By modeling the BRCs found in the BMP Database Addendum, and achieving relatively consistent results with the reported performances, gave reason to believe that SWMM can provide reliable prediction of BRC performance. 


\section{CHAPTER 5: UNCERTAINTY ANALYSIS RESULTS AND DISCUSSION}

The Uncertainty Analysis methods described previously (Muleta, McMillan, Amenu, \& Burian, 2013) were used for this study. Table 12 summarizes the results from the analysis. Reliability and sharpness are used to evaluate goodness of uncertainty analysis results. Reliability refers to the percentage of observed data that lies within the upper and lower prediction bounds identified by the uncertainty model. Ideal models have reliability of $100 \%$ where all observed data falls within the bound. Sharpness measures width of the uncertainty bounds. A perfect model will have identical lower and upper bounds (i.e., width and sharpness of the prediction bounds would be zero).

It is to be expected that the reliability of each model is to be higher for the calibration period than the validation period. A reliability value greater than $50 \%$ is deemed acceptable (Zhang \& Mahadevan, 2003), therefore all the models, except for the coarsest resolution (78-Subcatchment) model can be considered acceptable. The 78Subcatchment model displayed a reliability of only $36.17 \%$, too low to be considered a reliable model for use.

The most detailed (1414-Subcatchment) model was used as the reference model for determining sharpness and to compare sharpness among various resolutions. The same 
result as with the reliability was evident here with sharpness: the 78-Subcatchment model displaying a sharpness value lowers than the other models.

Table 12: Uncertainty Analysis Reliability / Sharpness.

\begin{tabular}{|c|c|c|c|}
\hline Model & Model Period & Reliability (\%) & Sharpness (\%) \\
\hline \multirow{2}{*}{78} & Calibration & 36.17 & 90.14 \\
\cline { 2 - 4 } & Validation & 16.99 & 89.93 \\
\hline \multirow{2}{*}{244} & Calibration & 63.5 & 100.1 \\
\cline { 2 - 4 } & Validation & 24.48 & 101.58 \\
\hline \multirow{2}{*}{738} & Calibration & 59.92 & 105.92 \\
\cline { 2 - 4 } & Validation & 23.66 & 105.12 \\
\hline \multirow{2}{*}{$1414 *$} & Calibration & 59.92 & 100 \\
\cline { 2 - 4 } & Validation & 22.05 & 100 \\
\hline \multicolumn{2}{|c|}{$*=$ reference model } & \multicolumn{2}{|c}{} \\
\hline
\end{tabular}

Figure 28 through Figure 35 show series plots for one week of the uncertainty analysis, for both the calibration and validation periods. The plots display the upper and lower bounds as determined from the uncertainty analysis, as well as the observed streamflow data. It can be seen that the observed data fell between the upper and lower bounds well for the calibration period, and not as well for the validation period, as described by the reliability values in Table 12 . 


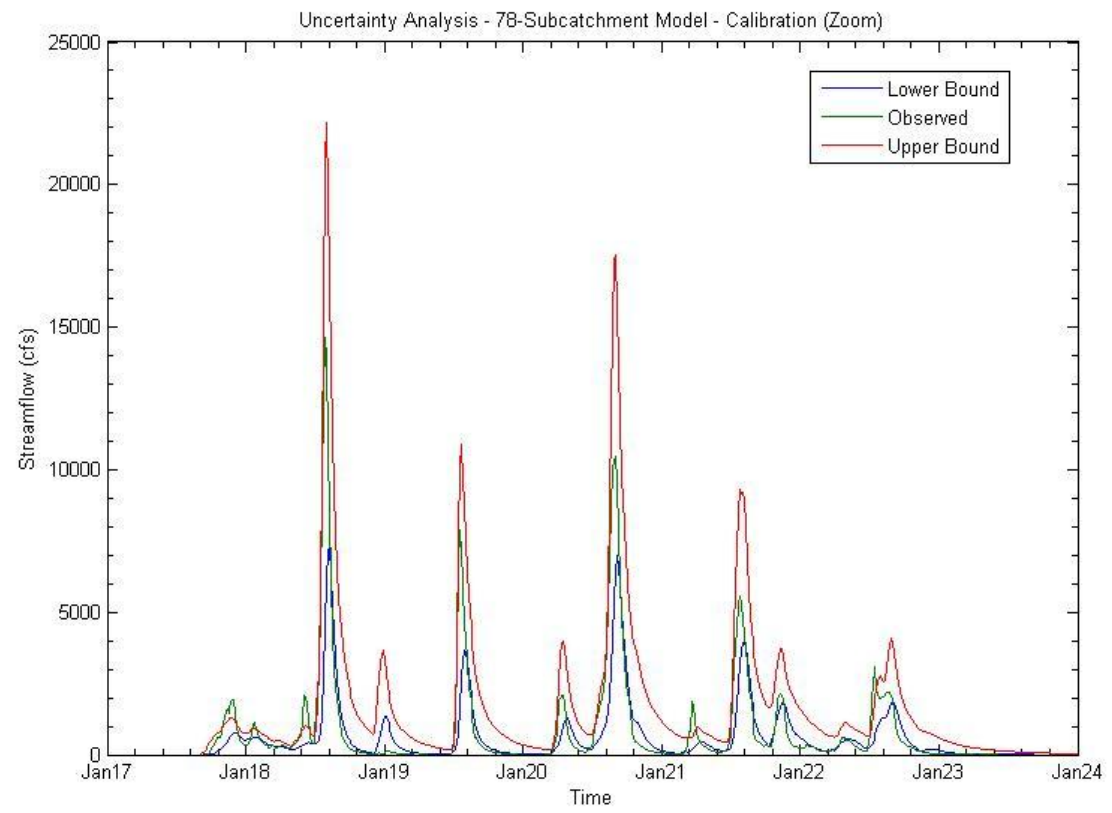

Figure 28: Uncertainty Analysis, 78-Subcatchment model, time series, calibration (zoomed-in).

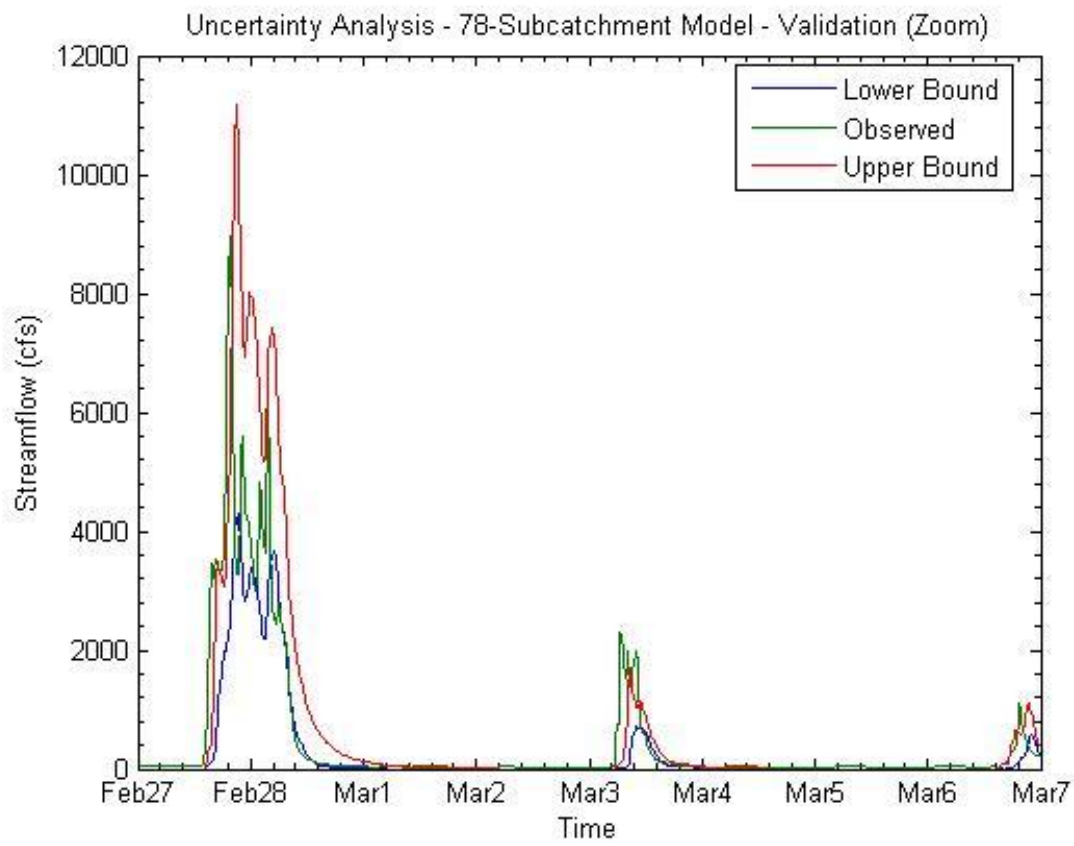

Figure 29: Uncertainty Analysis, 78-Subcatchment model, time series, validation (zoomed-in). 


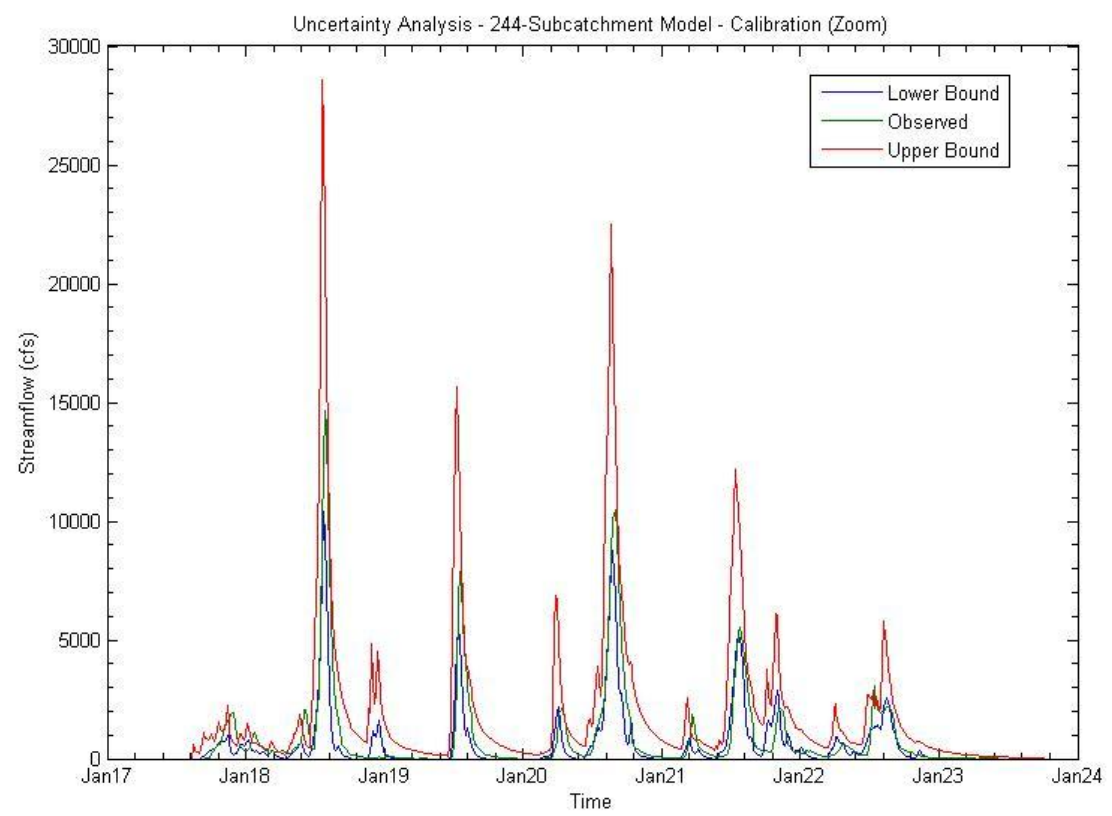

Figure 30: Uncertainty Analysis, 244-Subcatchment model, time series, calibration (zoomed-in).

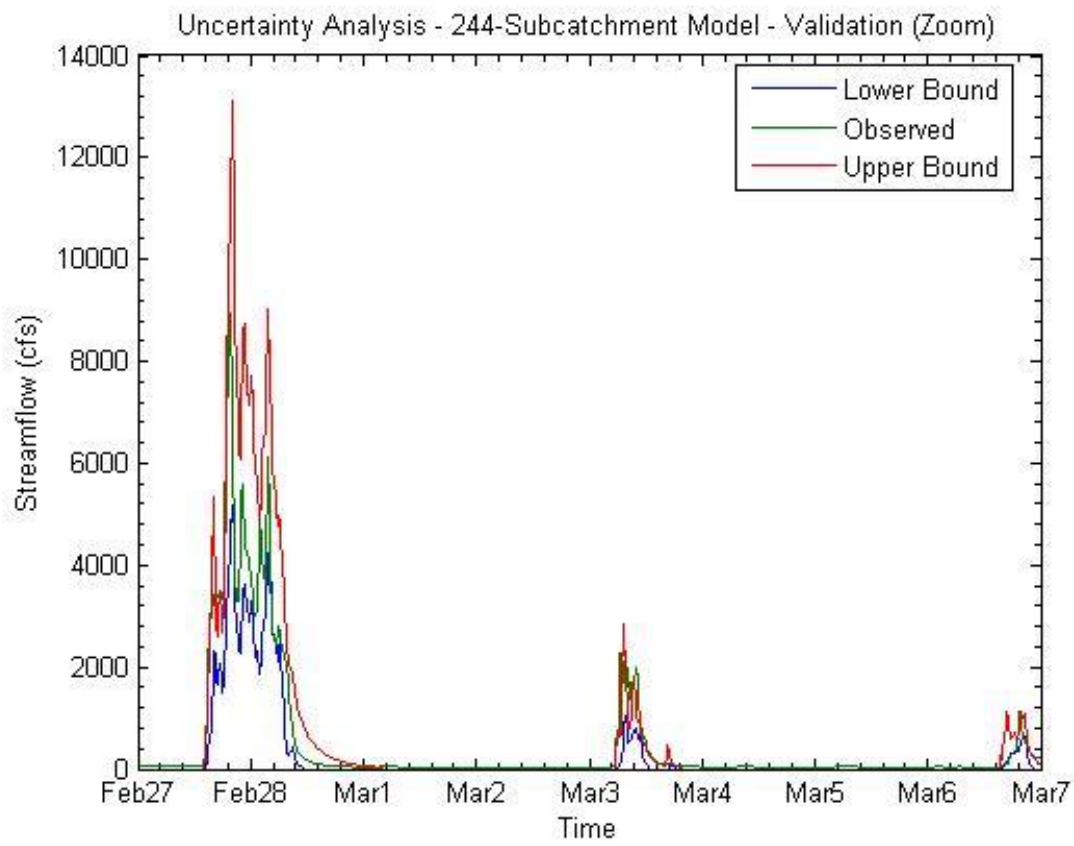

Figure 31: Uncertainty Analysis, 244-Subcatchment model, time series, validation (zoomed-in). 


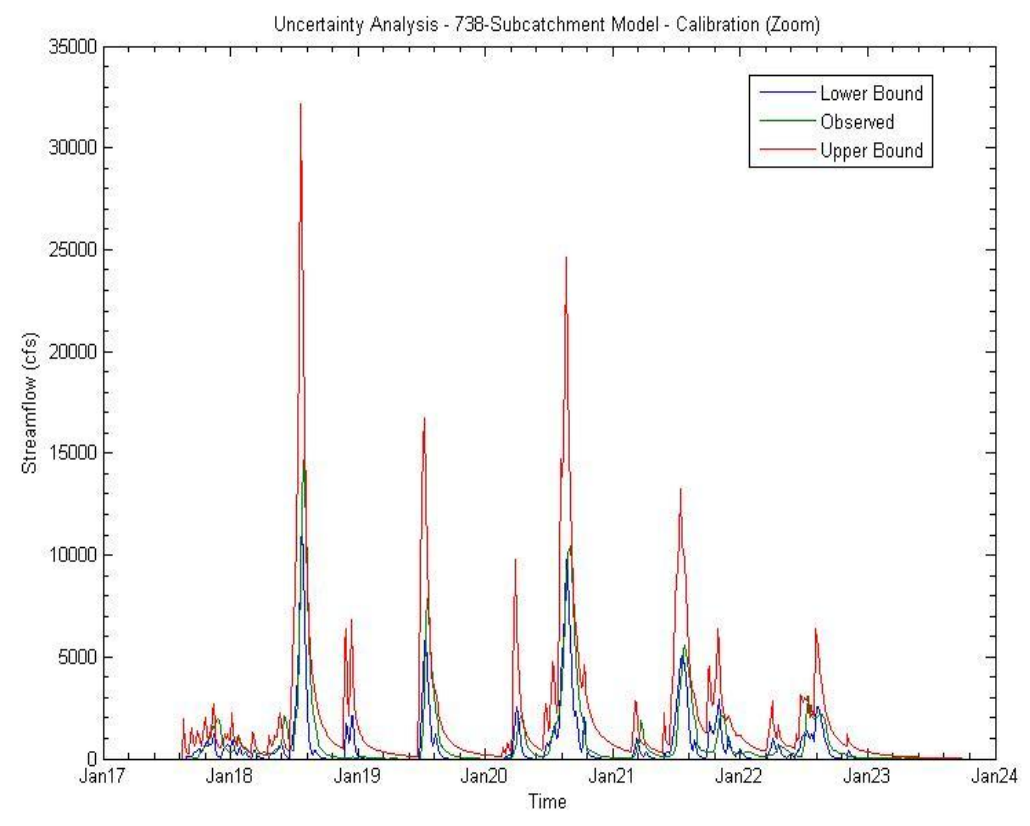

Figure 32: Uncertainty Analysis, 738-Subcatchment model, time series, calibration (zoomed-in).

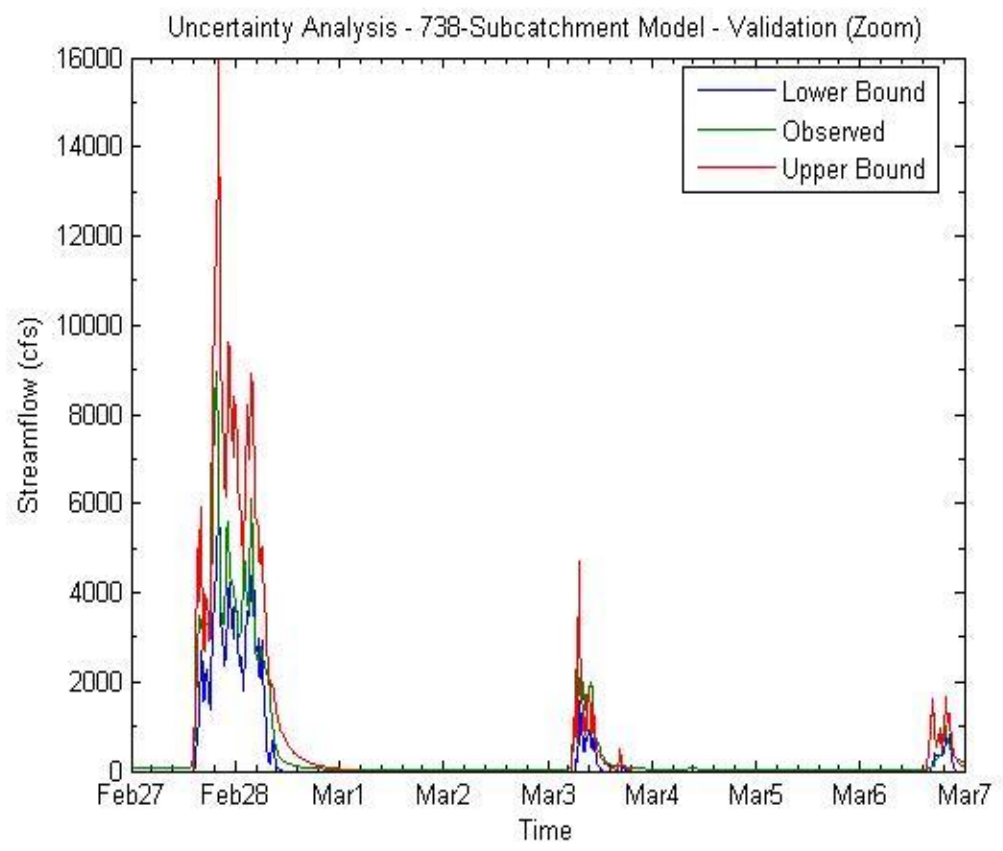

Figure 33: Uncertainty Analysis, 738-Subcatchment model, time series, validation (zoomed-in). 


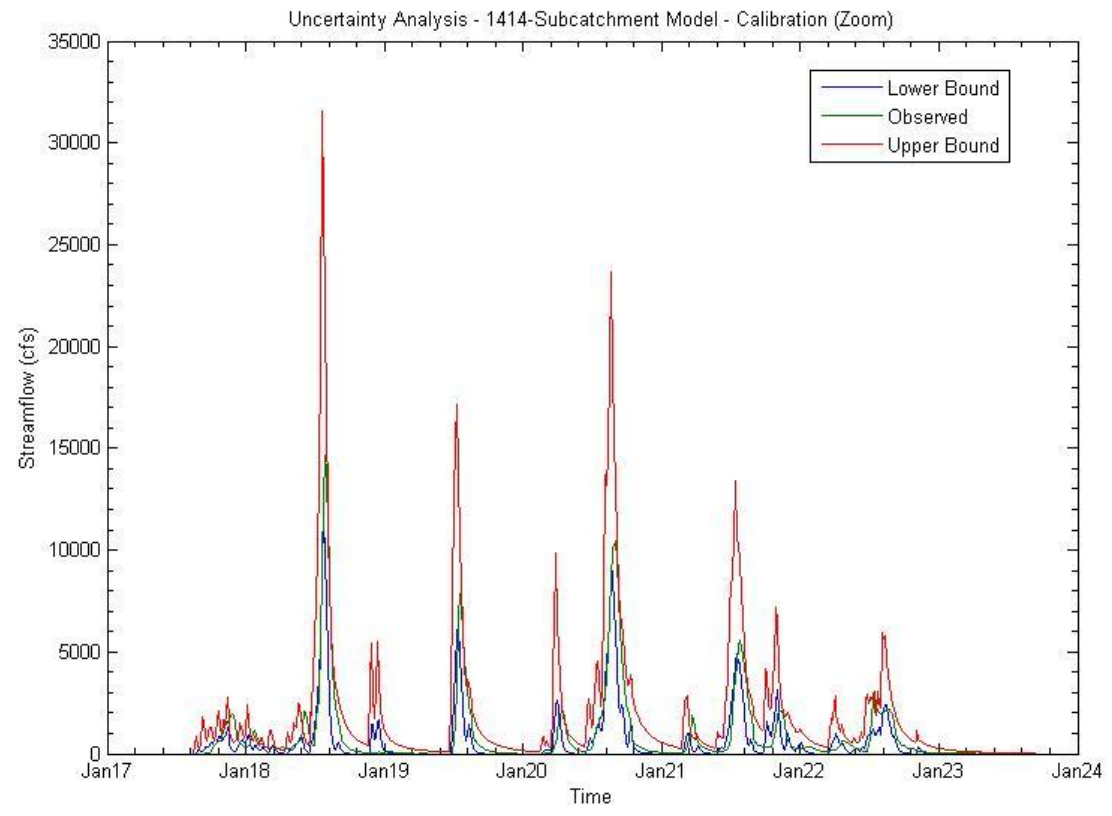

Figure 34: Uncertainty Analysis, 1414-Subcatchment model, time series, calibration (zoomed-in).

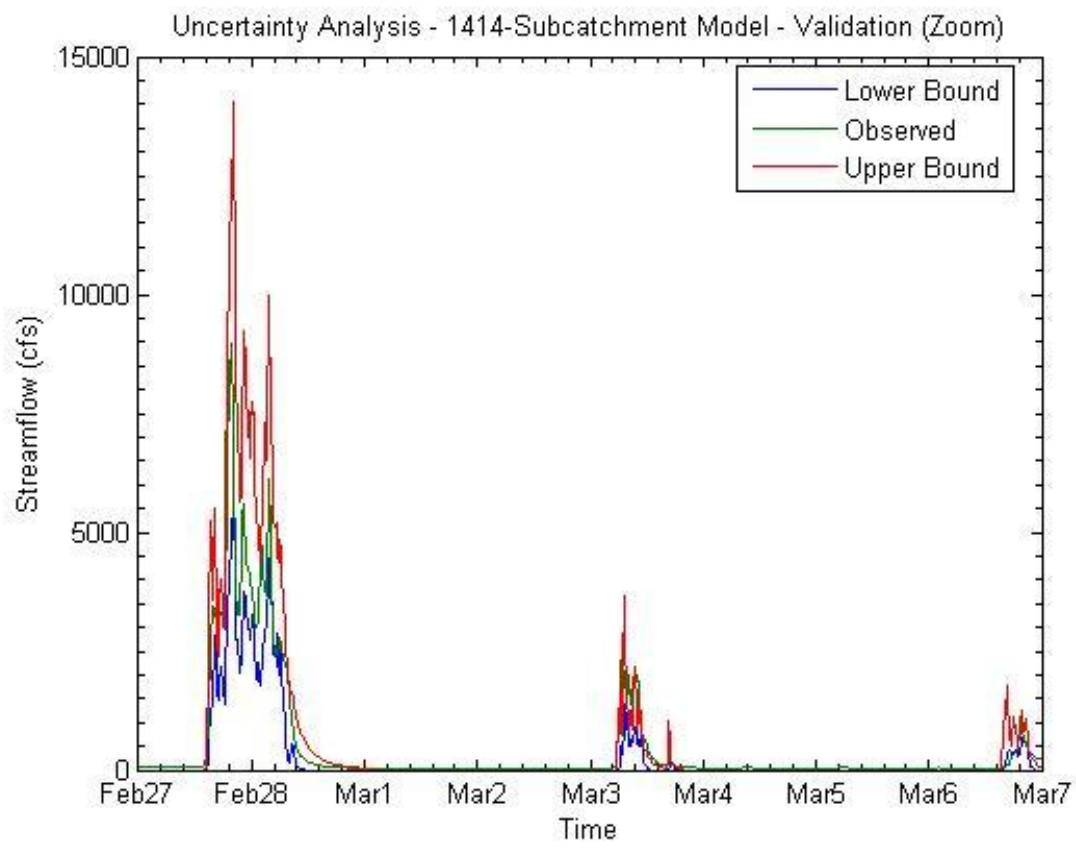

Figure 35: Uncertainty Analysis, 1414-Subcatchment model, time series, validation (zoomed-in). 
Figure 36 through Figure 40 shows posterior distribution of the five parameters considered for the uncertainty analysis. These plots show that the parameters are more or less uniformly distributed over the bounds considered for the analysis. This implies that runoff predictions are not sensitive to these parameters. Furthermore, the posteriors were nearly identical for all four models.

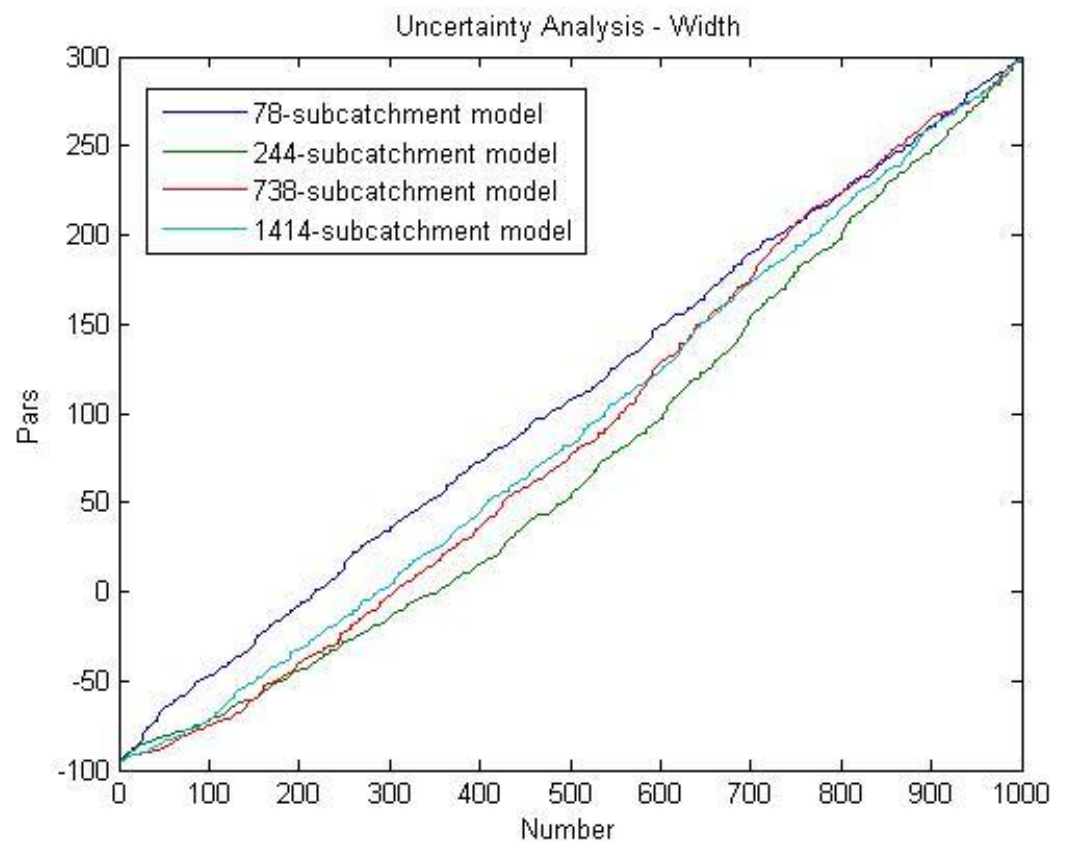

Figure 36: Uncertainty Analysis, line plot, Width. 


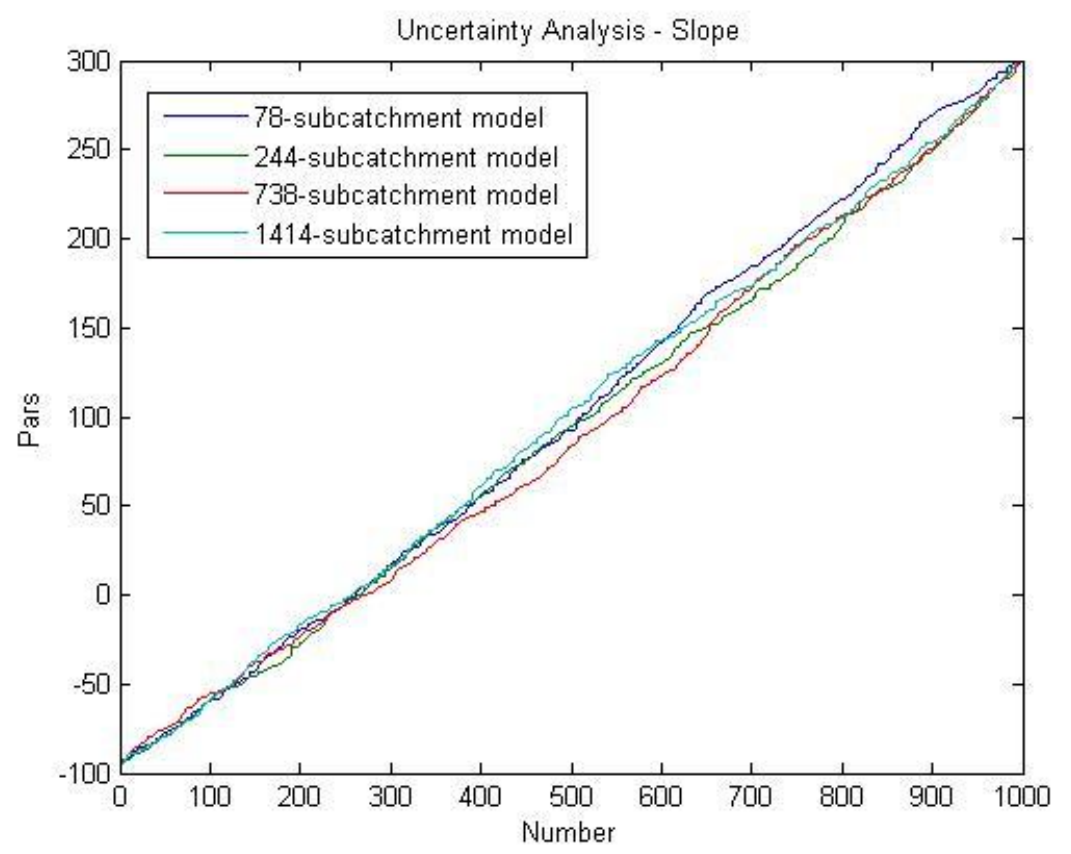

Figure 37: Uncertainty Analysis, line plot, Slope.

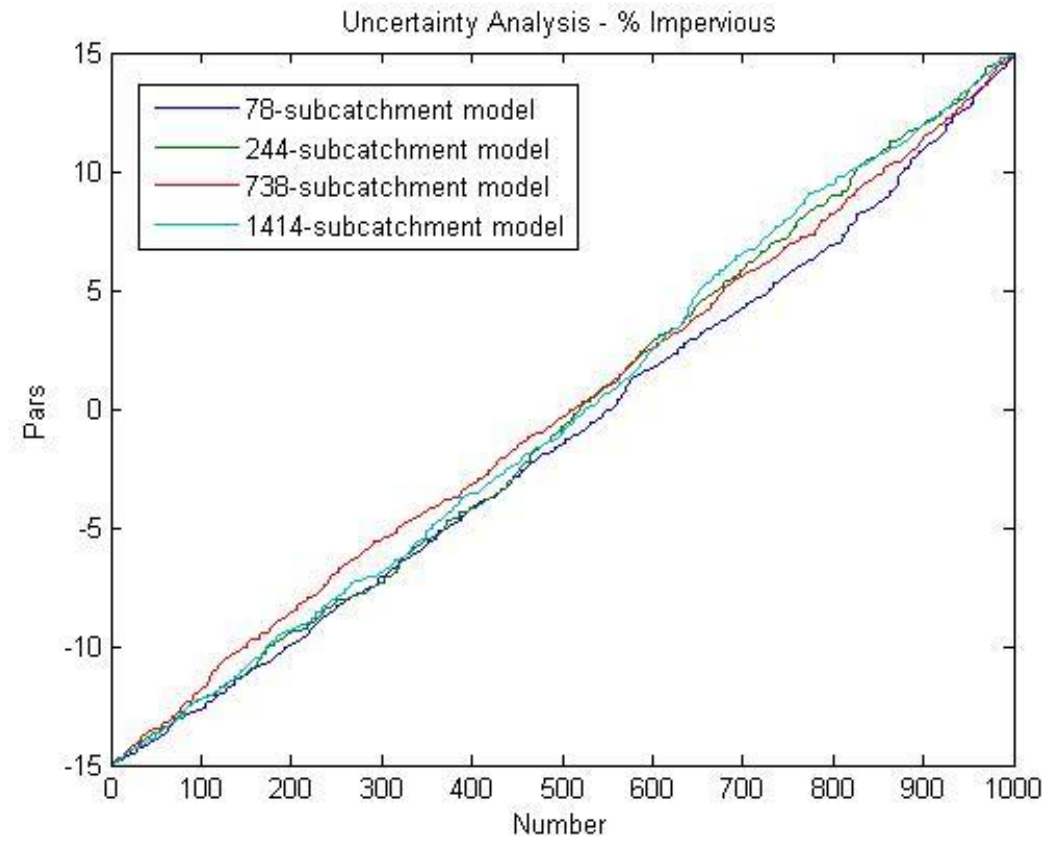

Figure 38: Uncertainty Analysis, line plot, Percent Impervious. 


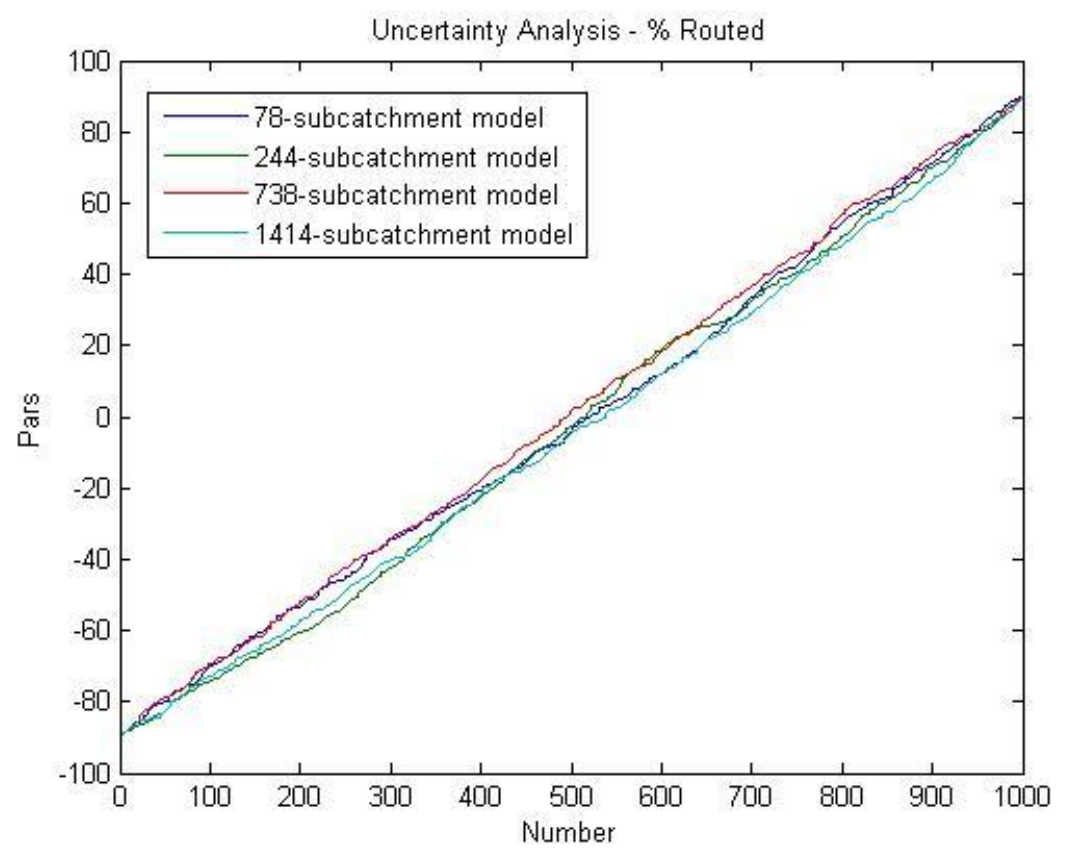

Figure 39: Uncertainty Analysis, line plot, Percent Routed.

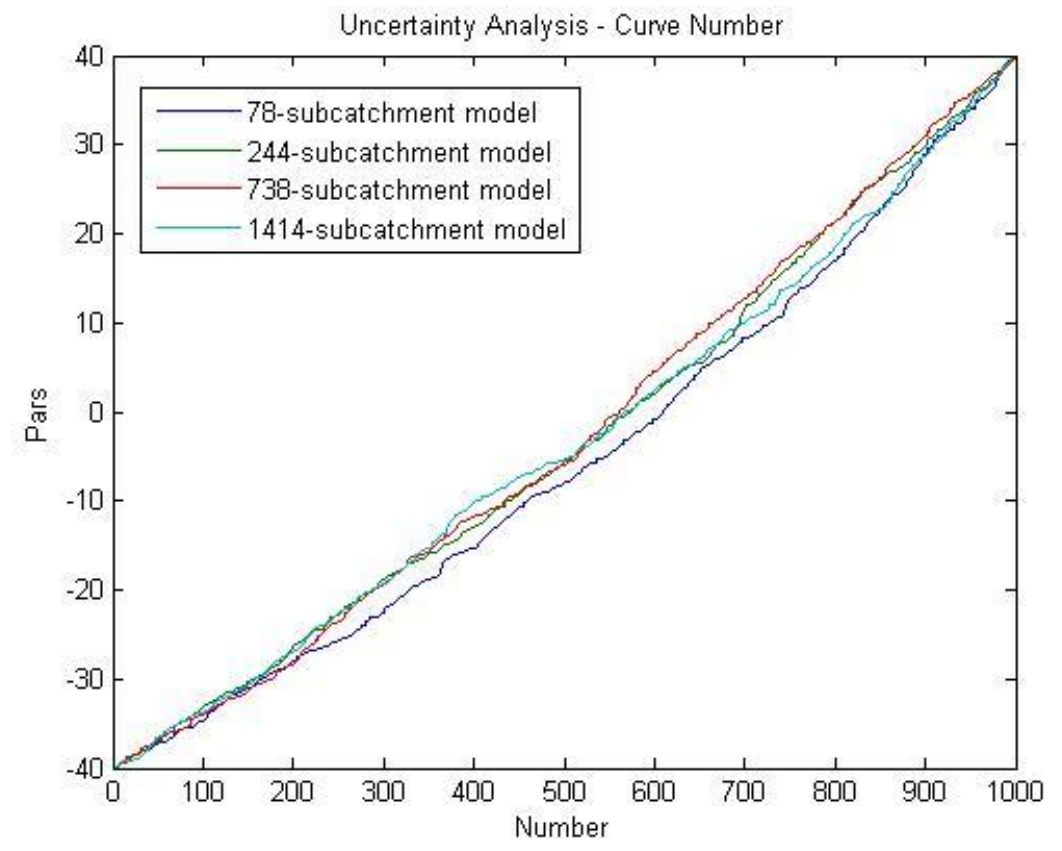

Figure 40: Uncertainty Analysis, line plot, Curve Number. 
Figure 65 through Figure 84 in Appendix C show histogram plots of the uncertainty analysis for each model, and for each parameter analyzed. These histograms show that, for the most part, the uncertainties in each parameter are relatively uniformly distributed within the prescribed ranges of values. The relative uniformity between models for each parameter suggests that the model scale did not play a significant role in affecting uncertainties for each parameter analyzed. 


\section{CHAPTER 6: LID IMPLEMENTATION RESULTS AND DISCUSSION}

Figure 41 through Figure 44 show runoff time series plots, for one week, of each model with and without the BRCs implemented, for the calibration period. These plots show the overall trend that the implementation of the BRCs decreases modeled streamflow.

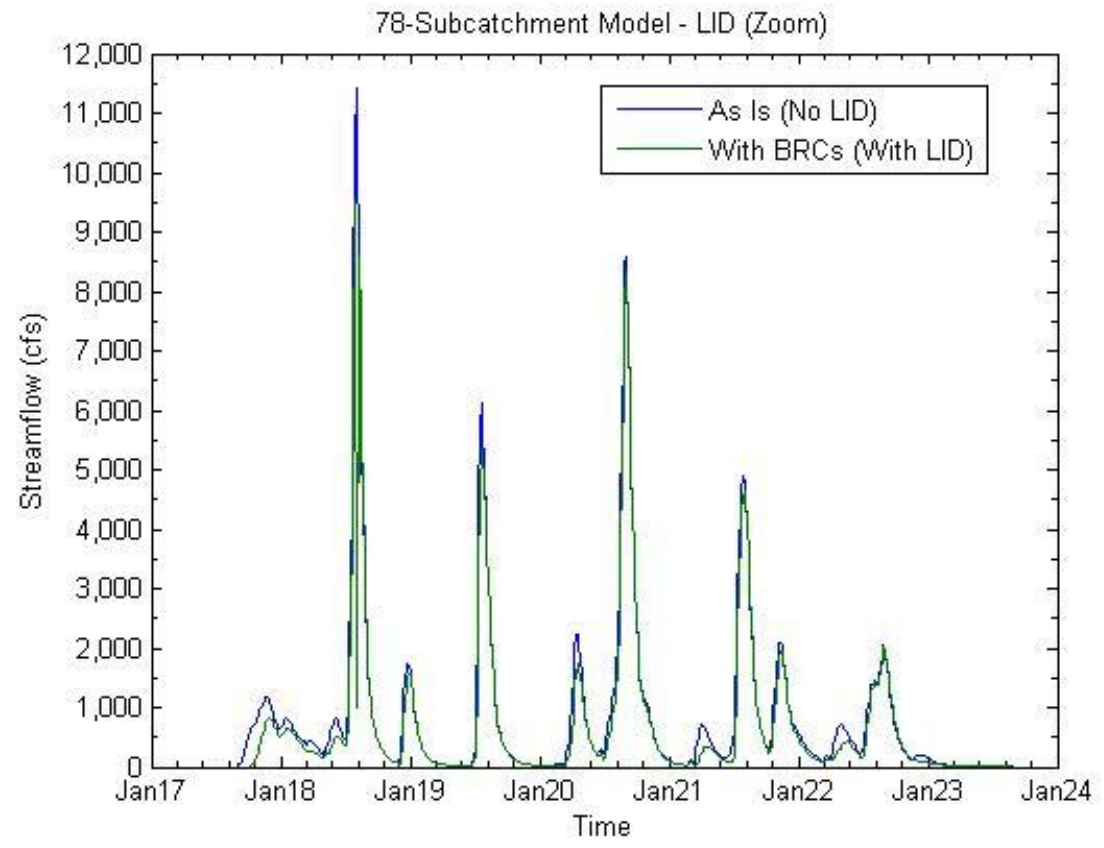

Figure 41: 78-Subcatchment model, with LID, zoomed-in. 


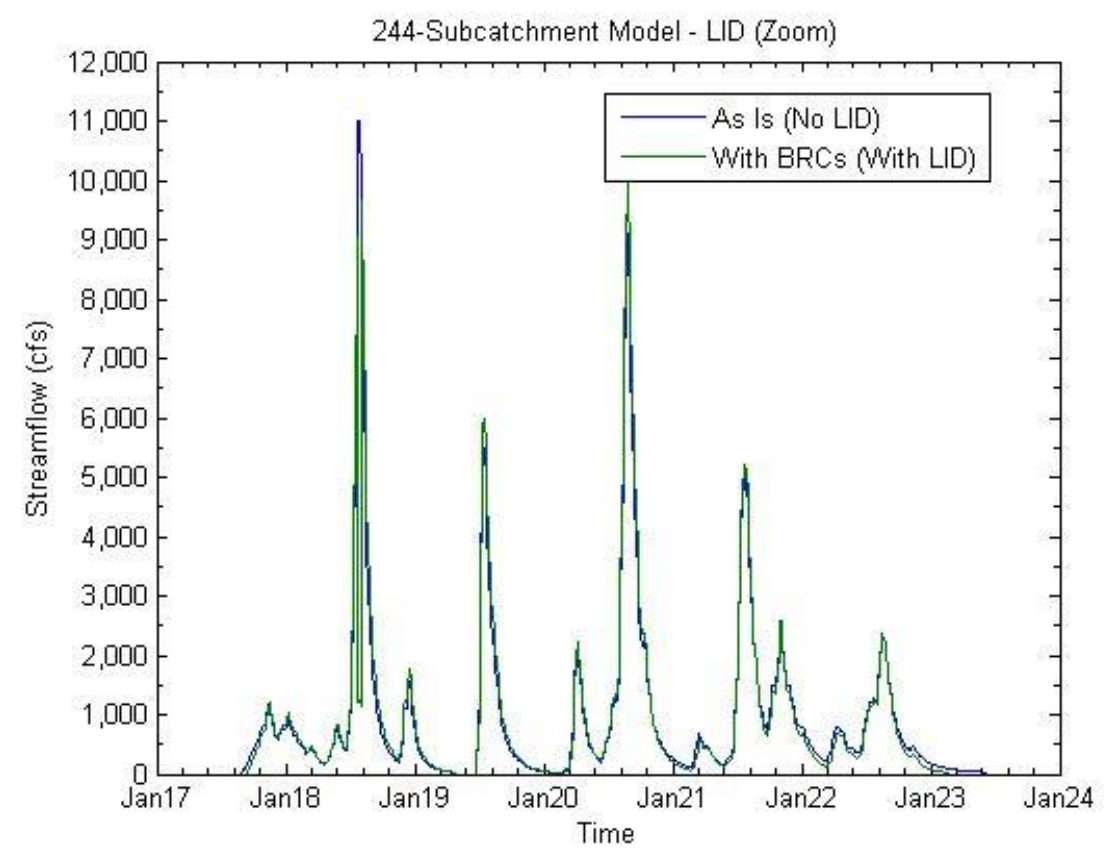

Figure 42: 244-Subcatchment model, with LID, zoomed-in.

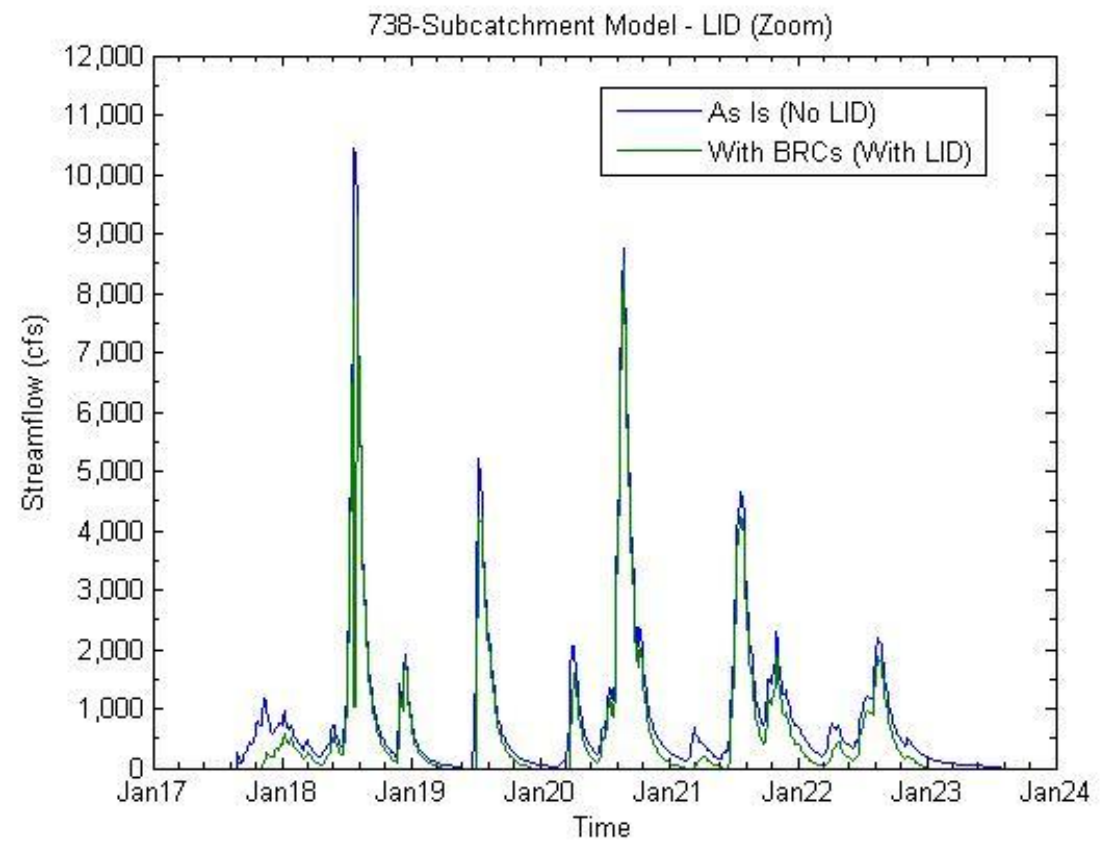

Figure 43: 738-Subcatchment model, with LID, zoomed-in. 


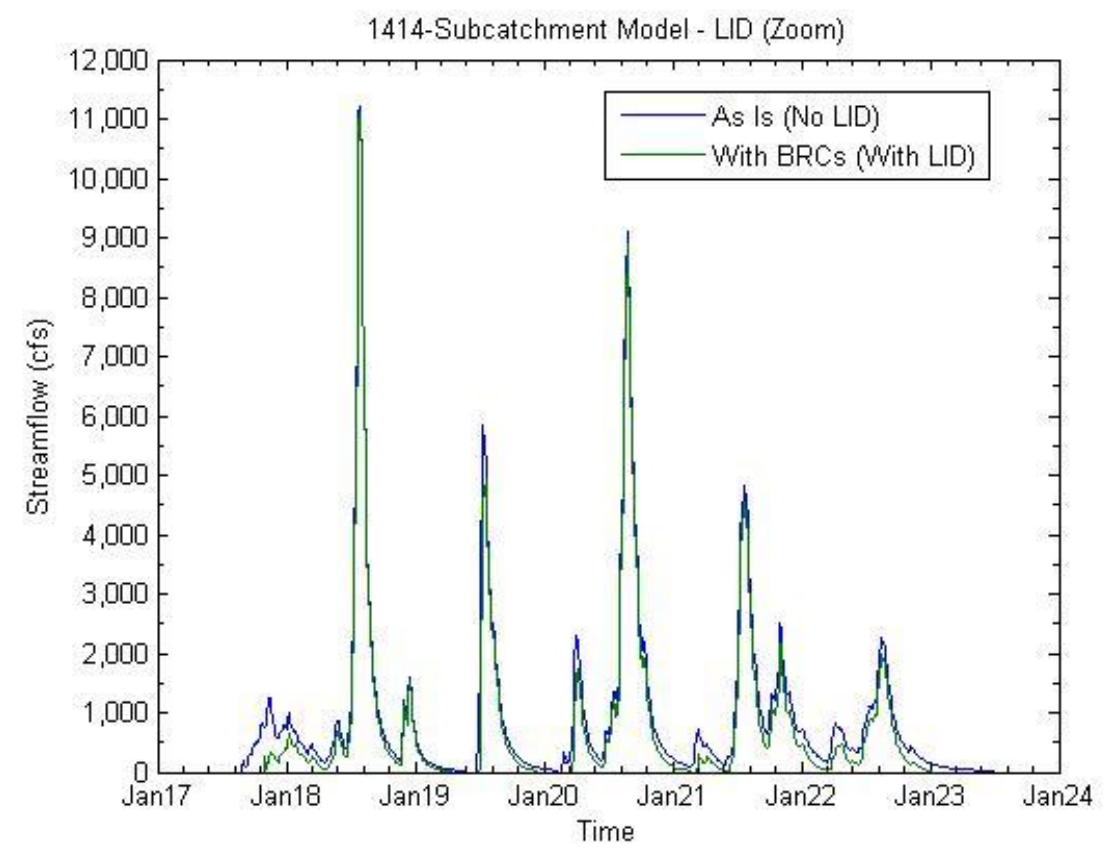

Figure 44: 1414-Subcatchment model, with LID, zoomed-in.

Figure 45 through Figure 48 show scatter plots of the modeled streamflow with and without the BRCs implemented. All of the data falls below the "No Change" line. This is to be expected, as the implementation of BRCs into the watershed should reduce the amount of runoff the watershed produces. 


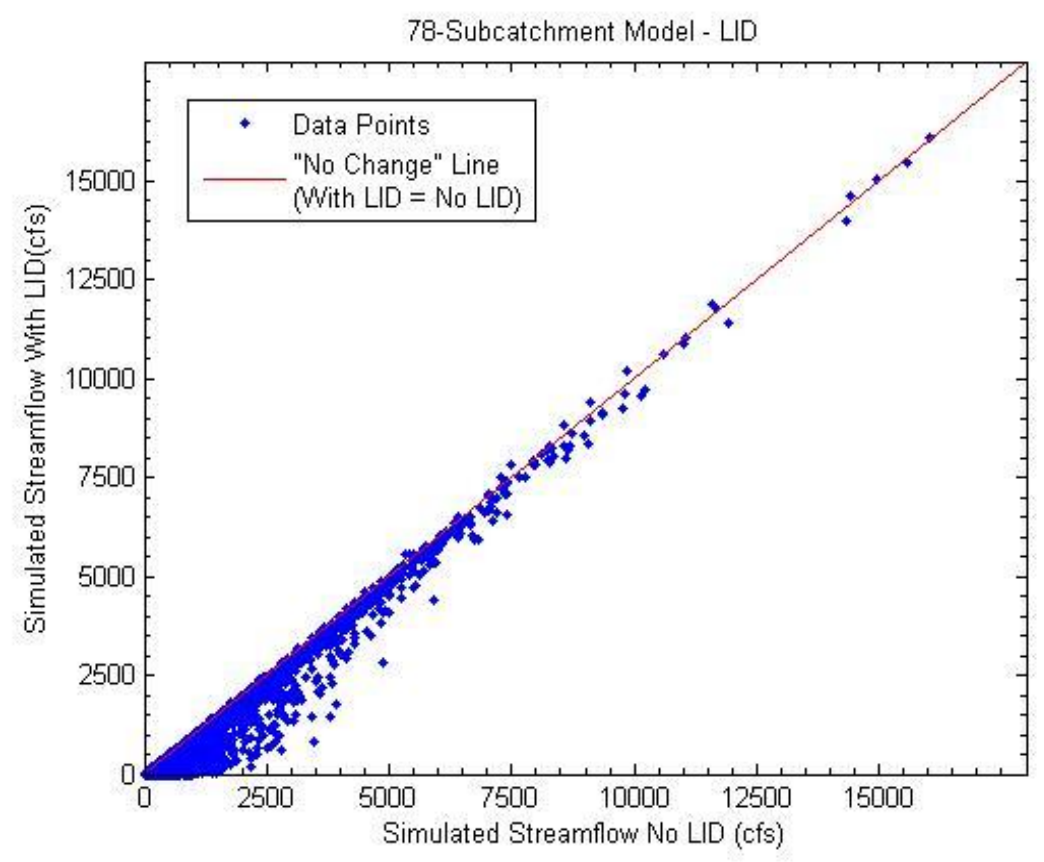

Figure 45: 78-Subcatchment model, LID scatter plot.

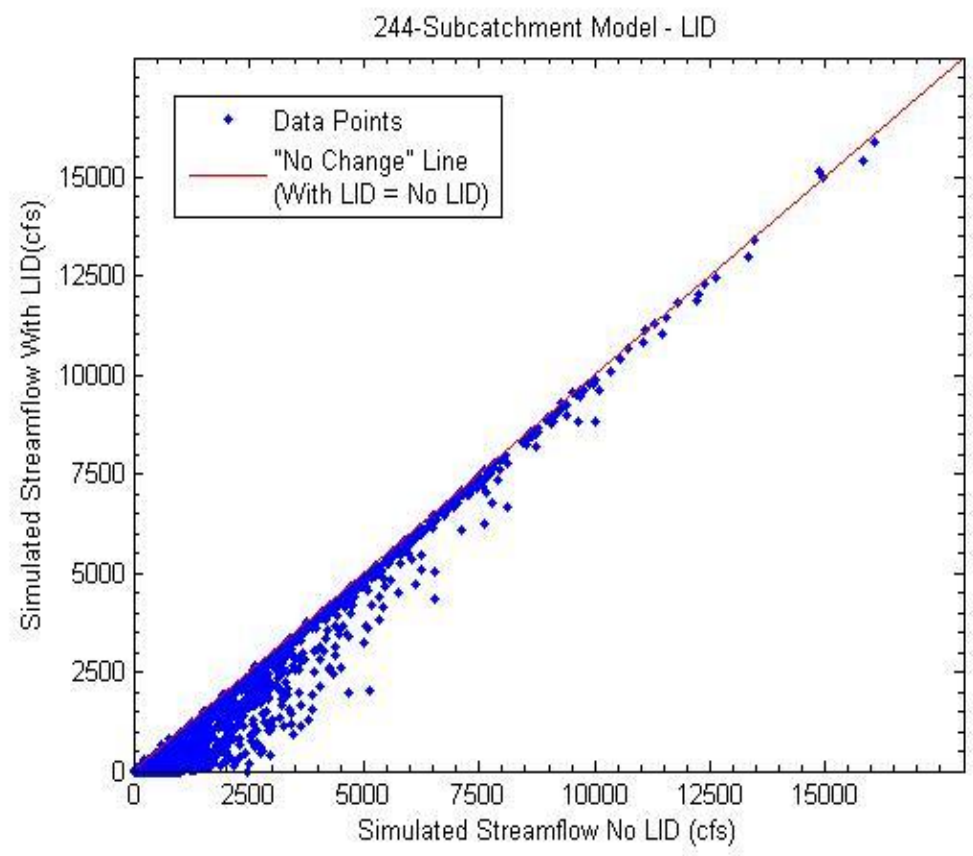

Figure 46: 244-Subcatchment model, LID scatter plot. 


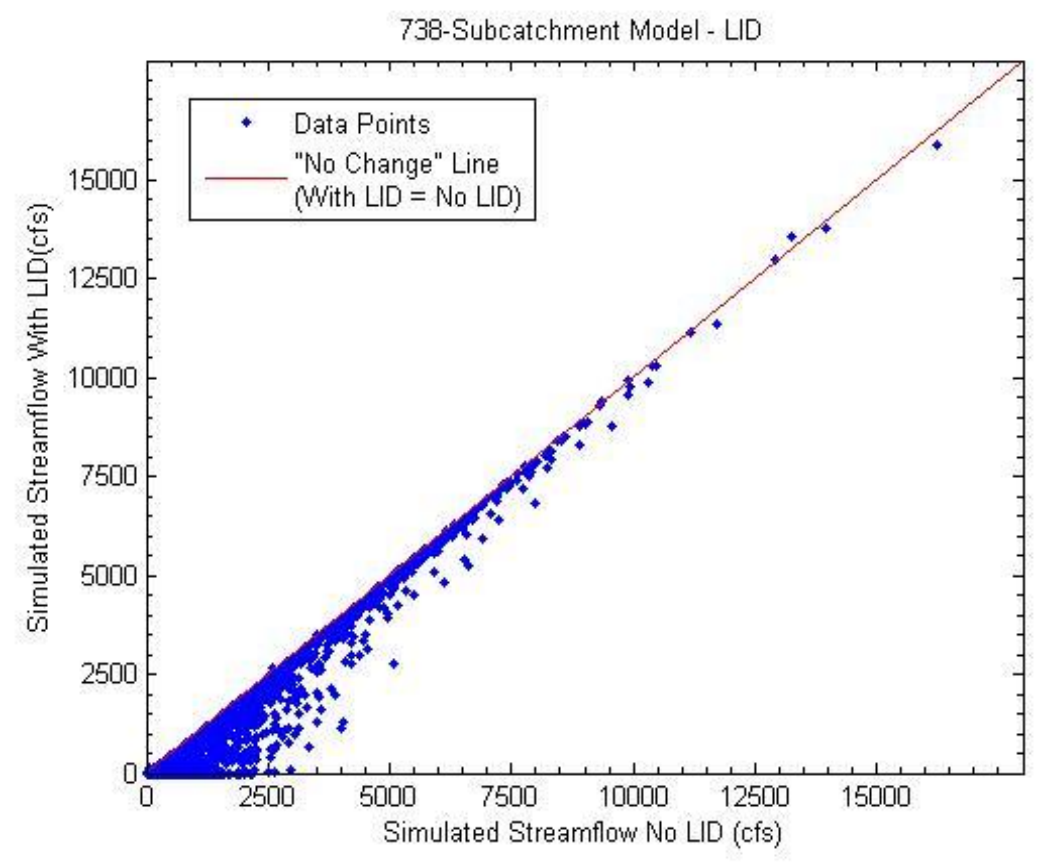

Figure 47: 738-Subcatchment model, LID scatter plot.

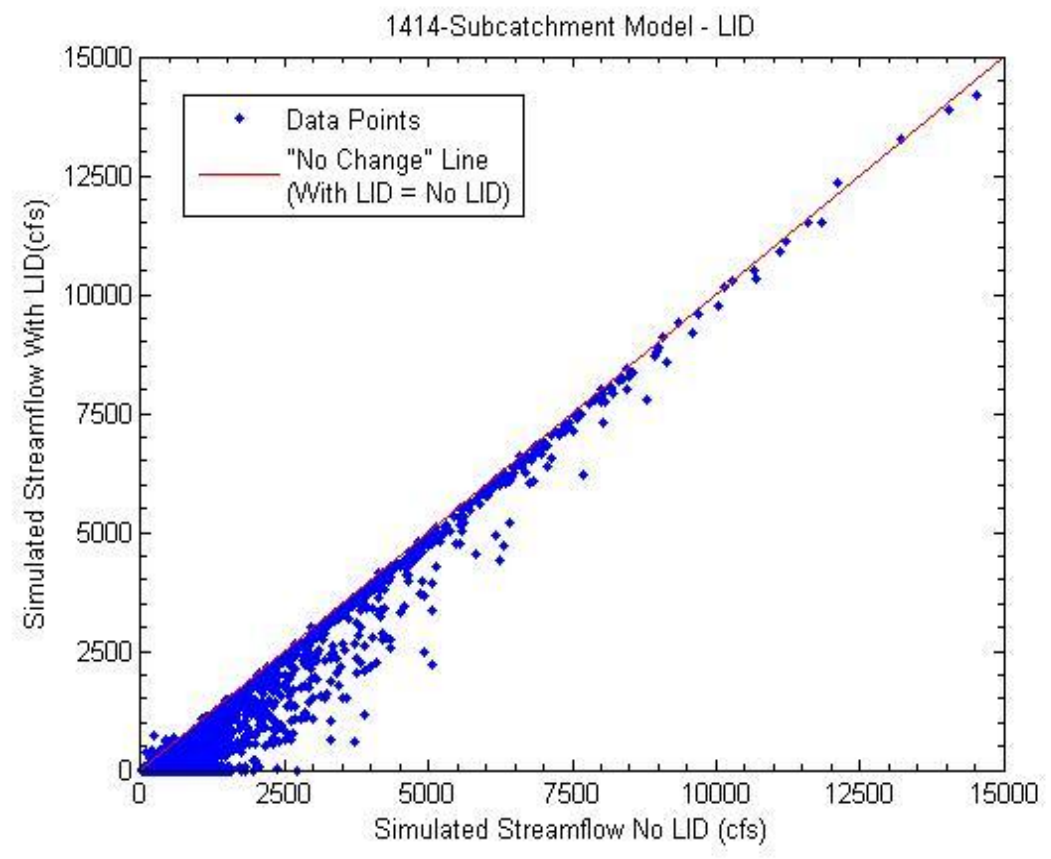

Figure 48: 1414-Subcatchment model, LID scatter plot. 
Table 13 through Table 16 shows the BRC performance for each model. Inflow volume refers to the total amount of water entering the watershed, and outflow volume refers to the total outflow of runoff leaving the Ballona Creek watershed. Appendix D shows the individual storm event hydrographs. These tables and figures show that the BRCs were most effective in reducing total runoff volume for the continuous time series (entire time period of October 2005 through March 2010), than for individual storm events. The BRCs were not nearly as successful in reducing total runoff volume for the event storms as they were for the tong-term continuous simulation.

Table 13: BRC Performance for 78-Subcatchment model.

\begin{tabular}{|c|c|c|c|c|c|}
\hline & \multicolumn{2}{|c|}{ No LID } & \multicolumn{2}{|c|}{ With LID } & \\
\hline $\begin{array}{c}\text { Storm } \\
\text { Frequency }\end{array}$ & $\begin{array}{c}\text { Inflow } \\
\text { Volume } \\
\text { (acre-ft) }\end{array}$ & $\begin{array}{l}\text { Outflow } \\
\text { Volume } \\
\text { (acre-ft) }\end{array}$ & $\begin{array}{c}\text { Inflow } \\
\text { Volume } \\
\text { (acre-ft) }\end{array}$ & $\begin{array}{l}\text { Outflow } \\
\text { Volume } \\
\text { (acre-ft) }\end{array}$ & Reduction (\%) \\
\hline $1-\mathrm{yr}$ & 19025.93 & 9902.32 & 19025.93 & 9528.575 & 3.77 \\
\hline $2-y r$ & 25246.63 & 13365.032 & 25246.63 & 13021.433 & 2.57 \\
\hline $5-y r$ & 33643.422 & 18455.18 & 33643.422 & 18161.304 & 1.59 \\
\hline $10-y r$ & 40780.465 & 23198.128 & 40780.465 & 22956.638 & 1.04 \\
\hline Continuous & 235538.598 & 111122.285 & 235538.598 & 86207.798 & 22.42 \\
\hline
\end{tabular}

Table 14: BRC Performance for 244-Subcatchment model.

\begin{tabular}{|c|c|c|c|c|c|}
\cline { 2 - 5 } \multicolumn{1}{c|}{} & \multicolumn{2}{c|}{ No LID } & \multicolumn{2}{c|}{ With LID } & \multicolumn{1}{c|}{} \\
\hline $\begin{array}{c}\text { Storm } \\
\text { Frequency }\end{array}$ & $\begin{array}{c}\text { Inflow } \\
\text { Volume } \\
\text { (acre-ft) }\end{array}$ & $\begin{array}{c}\text { Outflow } \\
\text { Volume } \\
\text { (acre-ft) }\end{array}$ & $\begin{array}{c}\text { Inflow } \\
\text { Volume } \\
\text { (acre-ft) }\end{array}$ & $\begin{array}{c}\text { Outflow } \\
\text { Volume } \\
\text { (acre-ft) }\end{array}$ & Reduction (\%) \\
\hline $1-y r$ & 19112.677 & 11944.306 & 19112.677 & 11255.309 & 5.77 \\
\hline $2-y r$ & 25328.812 & 16050.617 & 25328.812 & 15363.196 & 4.28 \\
\hline $5-y r$ & 33697.095 & 21647.495 & 33697.095 & 20963.848 & 3.16 \\
\hline $10-y r$ & 40781.405 & 26468.894 & 40781.405 & 25788.891 & 2.57 \\
\hline Continuous & 233087.538 & 123445.429 & 233087.538 & 93015.117 & 24.65 \\
\hline
\end{tabular}


Table 15: BRC Performance for 738-Subcatchment model.

\begin{tabular}{|c|c|c|c|c|c|}
\cline { 2 - 5 } \multicolumn{1}{c|}{} & \multicolumn{2}{c|}{ No LID } & \multicolumn{2}{c|}{ With LID } & \multicolumn{1}{c|}{} \\
\hline $\begin{array}{c}\text { Storm } \\
\text { Frequency }\end{array}$ & $\begin{array}{c}\text { Inflow } \\
\text { Volume } \\
\text { (acre-ft) }\end{array}$ & $\begin{array}{c}\text { Outflow } \\
\text { Volume } \\
\text { (acre-ft) }\end{array}$ & $\begin{array}{c}\text { Inflow } \\
\text { Volume } \\
\text { (acre-ft) }\end{array}$ & $\begin{array}{c}\text { Outflow } \\
\text { Volume } \\
\text { (acre-ft) }\end{array}$ & Reduction (\%) \\
\hline $1-y r$ & 19362.143 & 9825.75 & 19362.143 & 9143.519 & 6.94 \\
\hline $2-y r$ & 25690.897 & 13224.189 & 25690.897 & 12545.852 & 5.13 \\
\hline $5-y r$ & 34232.388 & 17849.387 & 34232.388 & 17177.88 & 3.76 \\
\hline $10-y r$ & 41490.938 & 21837.318 & 41490.938 & 21172.375 & 3.04 \\
\hline Continuous & 239512.338 & 103978.77 & 239512.338 & 74890.067 & 27.98 \\
\hline
\end{tabular}

Table 16: BRC Performance for 1414-Subcatchment model.

\begin{tabular}{|c|c|c|c|c|c|}
\cline { 2 - 5 } \multicolumn{1}{c|}{} & \multicolumn{2}{c|}{ No LID } & \multicolumn{2}{c|}{ With LID } & \multicolumn{1}{c|}{} \\
\hline $\begin{array}{c}\text { Storm } \\
\text { Frequency }\end{array}$ & $\begin{array}{c}\text { Inflow } \\
\text { Volume } \\
\text { (acre-ft) }\end{array}$ & $\begin{array}{c}\text { Outflow } \\
\text { Volume } \\
\text { (acre-ft) }\end{array}$ & $\begin{array}{c}\text { Inflow } \\
\text { Volume } \\
\text { (acre-ft) }\end{array}$ & $\begin{array}{c}\text { Outflow } \\
\text { Volume } \\
\text { (acre-ft) }\end{array}$ & Reduction (\%) \\
\hline $1-y r$ & 19069.207 & 10393.15 & 19069.207 & 9715.862 & 6.52 \\
\hline $2-y r$ & 25262.938 & 13954.432 & 25262.938 & 13280.292 & 4.83 \\
\hline $5-y r$ & 33604.36 & 18791.908 & 33604.36 & 18123.583 & 3.56 \\
\hline $10-y r$ & 40669.027 & 22950.216 & 40669.027 & 22287.574 & 2.89 \\
\hline Continuous & 232575.233 & 107401.194 & 232575.233 & 77825.54 & 27.54 \\
\hline
\end{tabular}

Implementing BRCs into every subcatchment within a watershed may not be economically feasible, or even practical, due to the nature of how the subcatchment is used (land use, streets, etc.). Table 17 and Table 18 show the performance of single subcatchments' BRCs. Subcatchment 1708 is a larger subcatchment with about $75 \%$ impervious area and a total area of 4-acres, and Subcatchment 1519 is a small subcatchment only about $5 \%$ impervious with a total area of 2-acres. It is apparent that the BRCs are more effective, and beneficial, in subcatchments with larger percentage of impervious area, as shown by the higher percent reduction in outflow volume Subcatchment 1708. Subcatchments with greater impervious area produce a larger 
amount of runoff than subcatchments with less impervious area, so implementing BRCs into these subcatchments allows them to work with a larger quantity of water, and therefore more effectively. Subcatchments that generate a small amount of runoff may not be able to fully utilize the BRC that is built; the stormwater runoff essentially bypasses the LID feature. The comparison of these two individual subcatchments show that carefully selecting where to implement LID features within the watershed is important in reducing runoff quantity.

Table 17: BRC Performance for a single subcatchment (Subcatchment 1708 from the 1414-Subcatchment model).

\begin{tabular}{|c|c|c|c|c|c|}
\cline { 2 - 5 } \multicolumn{1}{c|}{} & \multicolumn{2}{c|}{ No LID } & \multicolumn{2}{c|}{ With LID } & \multicolumn{1}{c|}{} \\
\hline $\begin{array}{c}\text { Storm } \\
\text { Frequency }\end{array}$ & $\begin{array}{c}\text { Inflow } \\
\text { Volume } \\
\text { (acre-ft) }\end{array}$ & $\begin{array}{c}\text { Outflow } \\
\text { Volume } \\
\text { (acre-ft) }\end{array}$ & $\begin{array}{c}\text { Inflow } \\
\text { Volume } \\
\text { (acre-ft) }\end{array}$ & $\begin{array}{c}\text { Outflow } \\
\text { Volume } \\
\text { (acre-ft) }\end{array}$ & Reduction (\%) \\
\hline $1-\mathrm{yr}$ & 1.587 & 1.156 & 1.587 & 1.111 & 3.89 \\
\hline $2-\mathrm{yr}$ & 2.12 & 1.559 & 2.12 & 1.515 & 2.82 \\
\hline $5-\mathrm{yr}$ & 2.847 & 2.114 & 2.847 & 2.07 & 2.08 \\
\hline $10-\mathrm{yr}$ & 3.473 & 2.598 & 3.473 & 2.554 & 1.69 \\
\hline Continuous & 20.887 & 13.452 & 20.887 & 10.976 & 18.41 \\
\hline
\end{tabular}

Table 18: BRC Performance for a single subcatchment (Subcatchment 1519 from the 1414-Subcatchment model).

\begin{tabular}{|c|c|c|c|c|c|}
\cline { 2 - 5 } \multicolumn{1}{c|}{} & \multicolumn{2}{c|}{ No LID } & \multicolumn{2}{c|}{ With LID } & \multicolumn{1}{c|}{} \\
\hline $\begin{array}{c}\text { Storm } \\
\text { Frequency }\end{array}$ & $\begin{array}{c}\text { Inflow } \\
\text { Volume } \\
\text { (acre-ft) }\end{array}$ & $\begin{array}{c}\text { Outflow } \\
\text { Volume } \\
\text { (acre-ft) }\end{array}$ & $\begin{array}{c}\text { Inflow } \\
\text { Volume } \\
\text { (acre-ft) }\end{array}$ & $\begin{array}{c}\text { Outflow } \\
\text { Volume } \\
\text { (acre-ft) }\end{array}$ & Reduction (\%) \\
\hline $1-\mathrm{yr}$ & 0.793 & 0.042 & 0.793 & 0.042 & 0.00 \\
\hline $2-\mathrm{yr}$ & 0.53 & 0.03 & 0.53 & 0.03 & 0.00 \\
\hline $5-\mathrm{yr}$ & 1.423 & 0.101 & 1.423 & 0.1 & 1.00 \\
\hline $10-\mathrm{yr}$ & 1.737 & 0.156 & 1.737 & 0.155 & 0.65 \\
\hline Continuous & 10.443 & 0.962 & 10.443 & 0.898 & 6.65 \\
\hline
\end{tabular}




\section{CHAPTER 7: CONCLUSIONS AND RECOMMENDATIONS}

Upon conclusion of this research, it can be determined that there is a limit to the prediction accuracy achieved by making urban stormwater management model spatial resolutions more detailed. It can also be concluded that LID implementation on a watershed scale can be effective in reducing overall stormwater runoff quantity for more frequent, but less intense, rains.

The conclusions of this study can be summarized as:

- The SWMM model parameters provided an accurate fit with the observed streamflow data;

- The model validation results, while not as accurate as the calibration, were also very good, leading to good reason to believe in the integrity of the models;

- For all five model parameters, the prediction uncertainties were significantly worse for the coarsest scaled model, while each of the three more detailed models showed very similar results for prediction uncertainties;

- Stormwater runoff quantity was not sensitive to spatial scale, except for the coarsest scale model, all other models all performed similarly;

- By calibrating SWMM to observed data for BRC performance, it was determined that SWMM does an adequate job of modeling such LIDs;

- LID performance was less effective for high intensity and less frequent storm events; 
- LID performance was successful at reducing overall stormwater runoff quantity for low intensity, continuous rains.

The first objective of this research was to determine the effect of spatial aggregation scale on prediction uncertainties for urban stormwater models. The same urban watershed was modeled at four different spatial scales, and the uncertainties for five different parameters analyzed. Generally, spatial scale did not have an effect on the prediction uncertainties, except for the coarsest resolution model, which had greater prediction uncertainty.

The second objective of this research was to evaluate LID performance at the watershedscale. By designing bioretention cells and then implementing them into the watershed models, the overall reduction in stormwater runoff quantity could be estimated. It was found that the implementation of bioretention cells into the watershed model had a greater reduction in runoff volume for long term, small storm events than for larger storm events.

Overall, this study shows that the uncertainties in urban watershed modeling are prevalent, and caution must be displayed when building watershed models. Urban watershed modeling, although difficult, is an efficient and affordable method for making water management and planning decisions. 


\section{$\underline{\text { RECOMMENDATIONS }}$}

Given the conclusions drawn from this research, future analysis is recommended. The models built had acceptable fits with the observed data, but could still achieve better results with the uncertainty analysis.

The Formal Bayesian Approach (Muleta, McMillan, Amenu, \& Burian, 2013) used for the uncertainty analysis did not match very well with the calibration and validation of the models. The models all proved to be very accurate for calibration and validation, but displayed large bounds for parameter uncertainties. This could be due to the uncertainty analysis method, or not accurate data being used to build the models. It is recommended that further study on the uncertainty analysis method is conducted.

Implementing LID features into a watershed at the watershed-scale has not been studied in much depth. In order to properly model LID features, observed performance data for existing LID features is necessary, to calibrate the designs. It is recommended that more effort be put into monitoring the performance of existing LID features in different climate regions, to be able to model newly proposed LID features accurately. 
Finally, this research looked solely at bioretention cells as the LID feature to analyze. It is recommended that further study be done on how other LID features (porous pavement, rain barrels, etc.) can be modeled at the watershed-scale, as well as combinations of these LID features in the regions of the watershed that would be applicable. 


\section{REFERENCES}

Amenu, G. G. (2011). A Comparative Study of Water Quality Conditions Between Heavily Urbanized and Less Urbanized Watersheds of Los Angeles Basin. World Environmental ad Water Resources Congress.

Bongiorni Ajello, T., Searing, M., Frost, W., \& van der Tak, L. (2005). Protecting Watershed Resources \& Quality Through Watershed Management Tools \& Models. Managing Watersheds for Human and Natural Impacts, 1-9.

Burian, S. J., McPherson, T. N., Brown, M. J., \& Turin, H. J. (2000). Development of a Stormwater Model for the Ballona Creek Watershed. Los Alamos National Laboratory.

California Environmental Protection Agency. (2014). Low Angeles Regional Water Quality Control Board. Retrieved from California Environmental Protection Agency.

City of Los Angeles. (2011). Development of Best Management Practices Handbook: Low Impact Development Manual. Retrieved from City of Los Angeles.

City of Los Angeles Stormwater Program. (2014). Retrieved from LA Stormwater: LA's Watershed Protection Program.

County of Los Angeles. (2013). Department of Public Works.

Elliott, A., Trowsdale, S., \& Wadhwa, S. (2009). Effect of Aggregation of On-Site Stormwater Control Devices in an Urban Catchment Model. Journal of Hydrologic Engineering, 975-983.

Geosyntec Consultants, Inc. (2012). International Stormwater Best Management Practices (BMP) Database: Addendum 1 to Volume Reduction Technical Summary (January 2011).

Google. (2014). Google Maps. Retrieved from Google.

Guo, J., \& Urbonas, B. (2009). Conversion of Natural Watershed to Kinematic Wave Cascading Plane. Journal of Hydrologic Engineering, Volume 14, Number 8, 839846.

Joseph, T. (2012). Catchment and Overland Flow Pathway Delineation Using LIDAR and GIS Grid Based Approach in Urban Stormwater and Sewer Network Models. Water New Zealand. 
Low Impact Development Center. (2007). Bioretention - Watershed Benefits. Retrieved March 25, 2014, from Urban Design Tools: Low Impact Development.

Luo, Z., Wang, T., Gao, M., Tang, J., \& Zhu, B. (2012). Stormwater Runoff Pollution in a Rural Townshup in the Hilly Area of the Central Sichuan Basin, China. Journal of Mountain Science, Volume 9, Number 1, 16-26.

Malsin, S. (2013). Ballona Creek Renaissance Non-Profit Organization. Retrieved April 8, 2014, from Ballona Creek Renaissance.

Mancipe-Munoz, N., Buchberger, S., Suidan, M., \& Lu, T. (2014). Calibration of Rainfall-Runoff Model in Urban Watersheds for Stormwater Management Assessment. Journal of Water Resources Planning and Management, Volume 10, (ASCE)WR.1943-5452.0000382, 05014001.

Mays, L. W. (2005). Water Resources Engineering. Tempe: Jogn Wiley \& Sons, Inc.

Muleta, M. (2012). Model Performance Sensitivity to Objective Function During Automated Calibrations. Journal of Hydrologic Engineering, 756-767.

Muleta, M., McMillan, J., Amenu, G., \& Burian, S. (2013). Bayesian Approach for Uncertainty Analysis of an Urban Stormwater Model and Its Application to a Heavily Urbanized Watershed. Journal of Hydrologic Engineering, Volume 18, Number 10, 1360-1371.

Nakamura, J., \& Villagra, N. (2009). Hydrologic Modeling of the Little Crum Creek Watershed with SWMM.

National Research Council (NRC). (2008). Urban Stormwater Management in the United States. Retrieved from The National Academies Press.

Nix, S. J. (1994). Urban Stormwater Modeling. Boca Raton: Lewis Publishers.

NOAA. (2014). Hydrometeorological Design Studies Center: Precipitation Frequency Data Server (PFDS). Retrieved from NOAA's National Weather Service.

Perez-Pedini, C., Limbrunner, J., \& Vogel, R. (2005). Optimal Number and Location of BMPs for Stormwater Managment. Managing Watersheds for Human and Natural Impacts, 1-12.

Rossman, L. A. (2010). Stormwater Management Model User's Manual Version 5.0. Retrieved from United States Environmental Protectoin Agency (USEPA). 
Scharffenberg, W., \& Flemming, M. (2009). Hydraulic Modeling System HEC-HMS User's Manual, Version 3.4. Retrieved from United States Army Corps of Engineers.

Sun, N., Hall, M., Hong, B., \& Zhang, L. (2014). Impact of SWMM Catchment Discretization: Case Study in Syracuse, New York. Journal of Hydrologic Engineering, Volume 19, Number 1, 223-234.

United States Army Corps of Engineers. (2009, May). HEC-GeoHMS Geospatial Hydrologic Modeling Extension User's Manual. Retrieved from Hydrologiv Engineering Center.

United States Department of Agriculture (USDA). (1986). Natural Resources Conservatoin Service. Retrieved from Urban Hydrology for Small Watersheds: TR-55.

United States Geological Survey (USGS). (2013). United States Department of the Interior. Retrieved from USGS.

USDA Natural Resources Conservation Service. (2010). Stream Corridor Restoration. Retrieved from The Federal Interagency Stream Restoration Working Group.

Zhang, R., \& Mahadevan, S. (2003). Bayesian Methodology for Reliability Model Acceptance. Reliability Engineering and System Safety, Volume 80, 95-103. 


\section{APPENDIX A: BRC DESIGN CRITERIA}

Table 19: BRC Design criteria chart (City of Los Angeles, 2011).

\begin{tabular}{|c|c|c|c|c|c|c|c|}
\hline $\begin{array}{l}\text { Design } \\
\text { Parameter }\end{array}$ & Unit & $\begin{array}{l}\text { Basins and } \\
\text { Trenches }\end{array}$ & Galleries & Bioretention & $\begin{array}{l}\text { Permeable } \\
\text { Pavement }\end{array}$ & Dry Well & $\begin{array}{l}\text { Hybrid } \\
\text { Bioretention/ } \\
\text { Dry Well }\end{array}$ \\
\hline $\begin{array}{l}\text { Design Capture } \\
\text { Volume, } V_{\text {capture }}\end{array}$ & $\begin{array}{l}\text { cubic } \\
\text { feet }\end{array}$ & \multicolumn{6}{|c|}{$0.0625(\mathrm{ft}) \times$ Catchment Area (sq. ft.) ${ }^{4}$} \\
\hline $\begin{array}{l}\text { Design Surface } \\
\text { Drawdown Time }\end{array}$ & hr & \multicolumn{6}{|l|}{48} \\
\hline $\begin{array}{l}\text { Setbacks and } \\
\text { Elevations }\end{array}$ & feet & \multicolumn{6}{|c|}{ In accordance with the Infiltration Feasibility Criteria, Section 4.2} \\
\hline Pretreatment & - & \multicolumn{6}{|c|}{$\begin{array}{l}\text { Appropriate Treatment Control Measure shall be provided as pretreatment for all } \\
\text { tributary surfaces other than roofs }\end{array}$} \\
\hline $\begin{array}{l}\text { Hydraulic } \\
\text { Conductivity, } \\
\text { Kanmeasured }\end{array}$ & in $/ \mathrm{hr}$ & \multicolumn{6}{|c|}{$\begin{array}{l}\text { Measured hydraulic conductivity at the location of the proposed BMP at the depth of } \\
\text { the proposed infiltrating surface (or effective infiltration rate when multi directional } \\
\text { infiltration is occurring }\end{array}$} \\
\hline $\begin{array}{l}\text { Factor of Safety, } \\
\text { FS }^{6}\end{array}$ & - & \multicolumn{6}{|c|}{3} \\
\hline Facility geometry & - & $\begin{array}{l}\text { Bottom } \\
\text { slope } \leq 3 \% \\
\text { (basins); } \\
\text { side slope } \\
\text { shall not } \\
\text { exceed } 3: 1 \\
\text { (H:V) }\end{array}$ & $\begin{array}{l}\text { Flat } \\
\text { bottom } \\
\text { slope }\end{array}$ & $\begin{array}{l}\text { Bottom } \\
\text { slope } \leq 3 \% \text {; } \\
\text { side slope } \\
\text { shall not } \\
\text { exceed 3:1 } \\
(\mathrm{H}: \mathrm{V})\end{array}$ & $\begin{array}{l}\text { Pavement } \\
\text { slope } \leq 5 \% \text {; } \\
\text { If } \geq 2 \% \text {, } \\
\text { area shall } \\
\text { be terraced }\end{array}$ & $\begin{array}{l}\text { Typical } 18 \\
-36 \text { inch } \\
\text { diameter; } \\
\text { flat } \\
\text { bottom } \\
\text { slope }\end{array}$ & $\begin{array}{l}\text { Bioretention: } \\
\text { Bottom slope S } \\
\text { 3\%; side slope } \\
\text { shall not } \\
\text { exceed } 3: 1 \\
\text { Drywell: flat } \\
\text { bottom }\end{array}$ \\
\hline Ponding Depth & inch & \multicolumn{6}{|c|}{$18{\text { (maximum })^{c}}^{c}$} \\
\hline Media Depth & feet & $\begin{array}{l}2(\min ) \\
8(\max )\end{array}$ & - & $\begin{array}{l}2(\min ) \\
8(\max )\end{array}$ & $\begin{array}{l}2(\min ) \\
8(\max )\end{array}$ & - & $\begin{array}{l}2(\min ) \\
8(\max )\end{array}$ \\
\hline $\begin{array}{l}\text { Gravel media } \\
\text { diameter }\end{array}$ & inch & $1-3$ & - & - & $1-2$ & $3 / 8-1$ & $3 / 8-1$ \\
\hline $\begin{array}{l}\text { Inlet erosion } \\
\text { control }\end{array}$ & - & \multicolumn{6}{|c|}{ Energy dissipater to reduce velocity } \\
\hline Overflow device & - & \multicolumn{6}{|c|}{$\begin{array}{l}\text { Required if system is on-line and does not have an upstream bypass structure. Shall be } \\
\text { designed to handle the peak storm flow in accordance with the Building and Safety } \\
\text { code and requirements }\end{array}$} \\
\hline \multicolumn{8}{|c|}{$\begin{array}{l}\text { a: Catchment area = (impervious area } \times 0.9)+[(\text { pervious area + undeveloped area) } \times 0.1] \\
\text { b: Listed FS values to be used only if soil infiltration / percolation test was performed and a detailed geotechnical } \\
\text { report from a professional geotechnical engineer or engineering geologist is provided. A FS of } 6 \text { will be assigned } \\
\text { if only a boring was done. } \\
\text { c: Ponding depth may vary for galleries (which have a storage depth) and may be different from one vendor to } \\
\text { another. Ponding depth is not necessarily applicable to permeable pavement. }\end{array}$} \\
\hline
\end{tabular}




\section{APPENDIX B: CALIBRATION AND VALIDATION RESULTS}

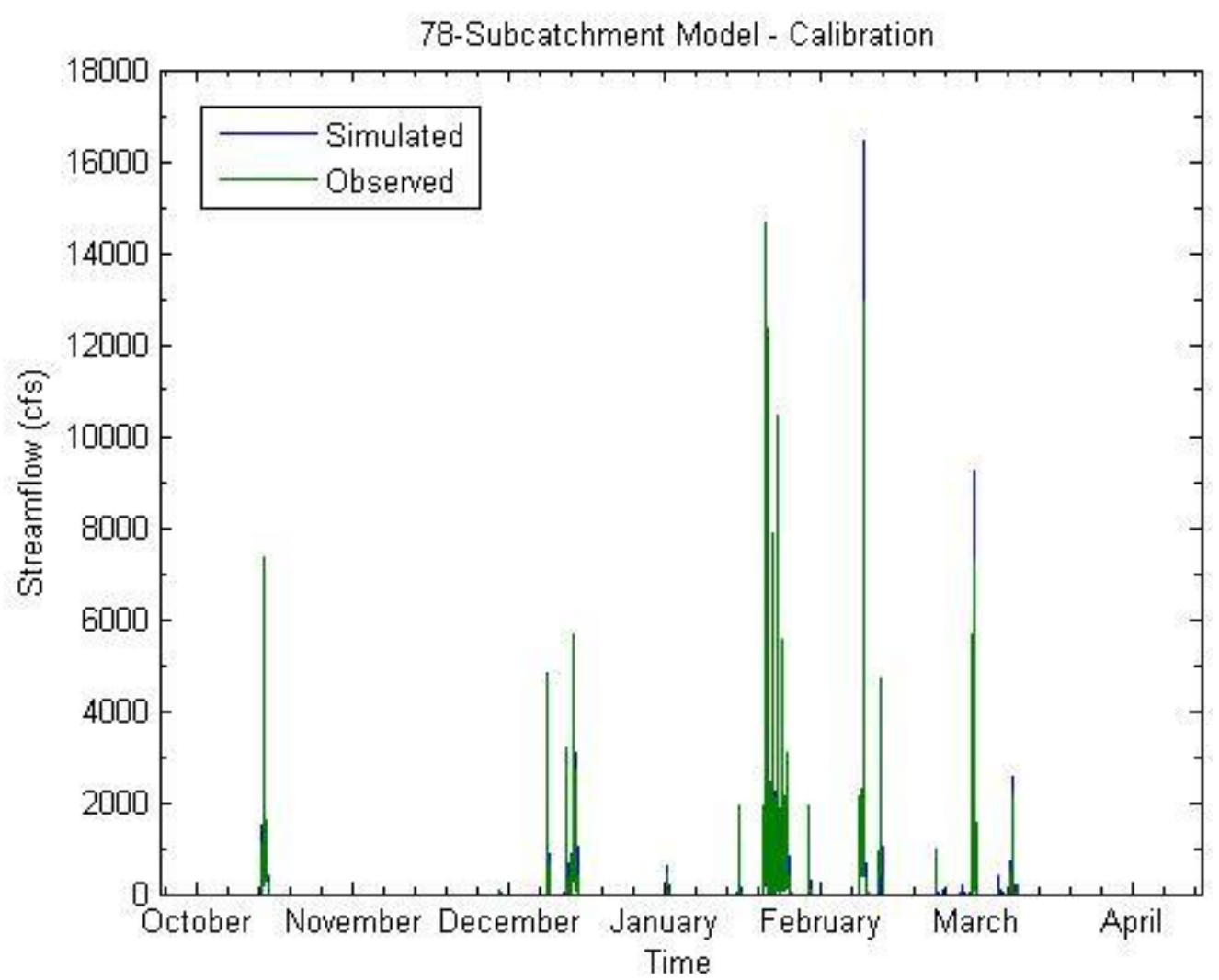

Figure 49: 78-Subcatchment model, calibration time series. 


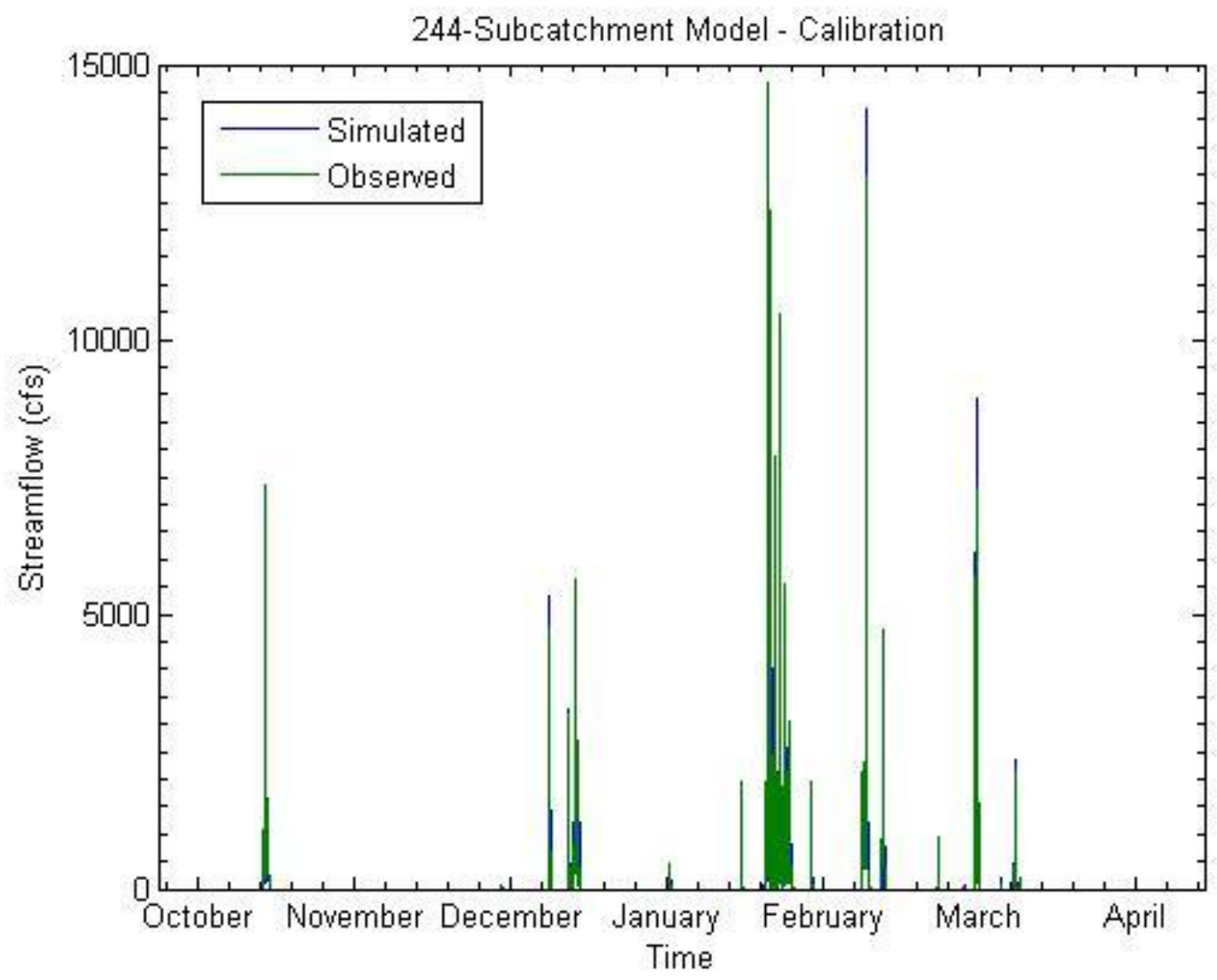

Figure 50: 244-Subcatchment model, calibration time series. 


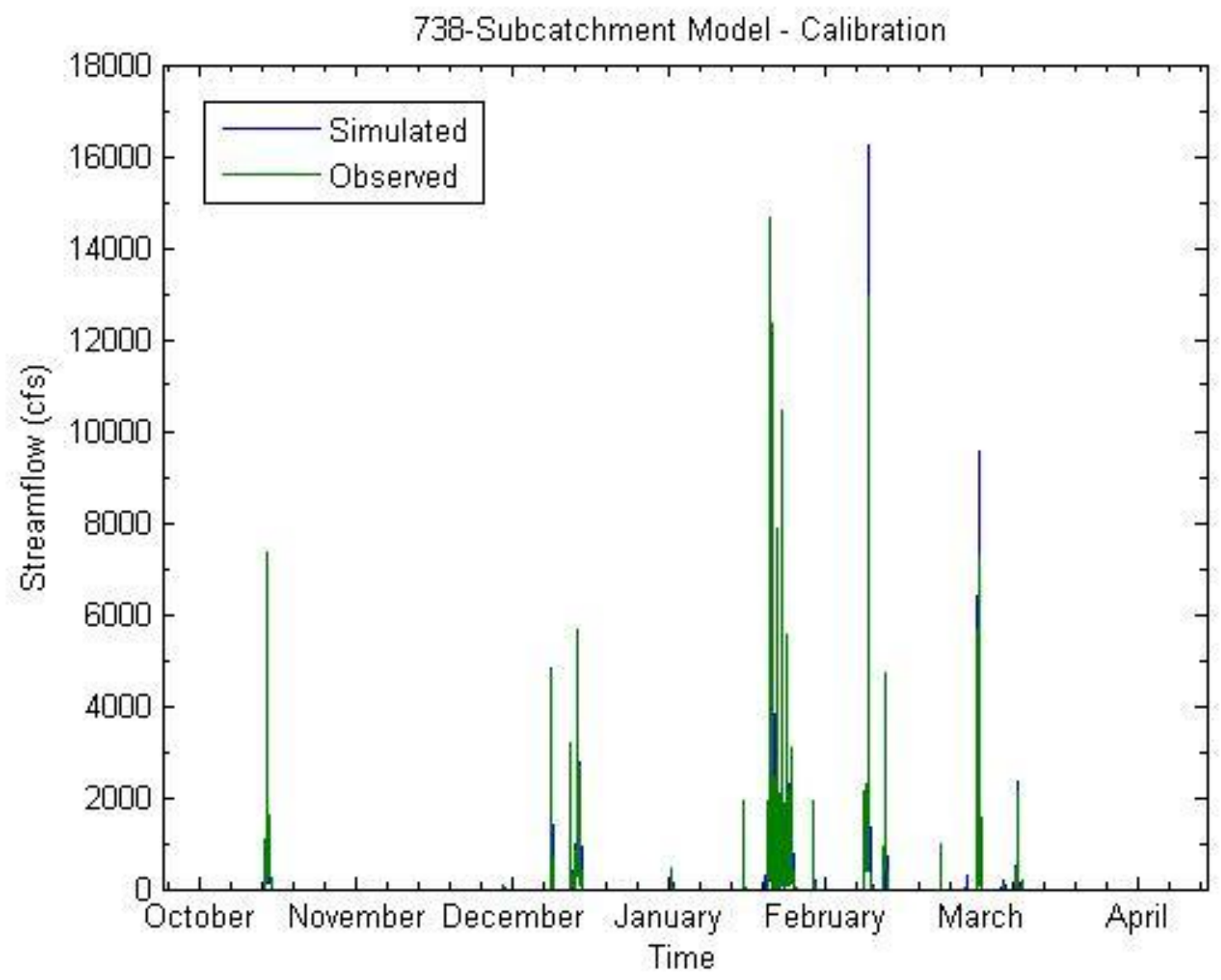

Figure 51: 738-Subcatchment model, calibration time series. 


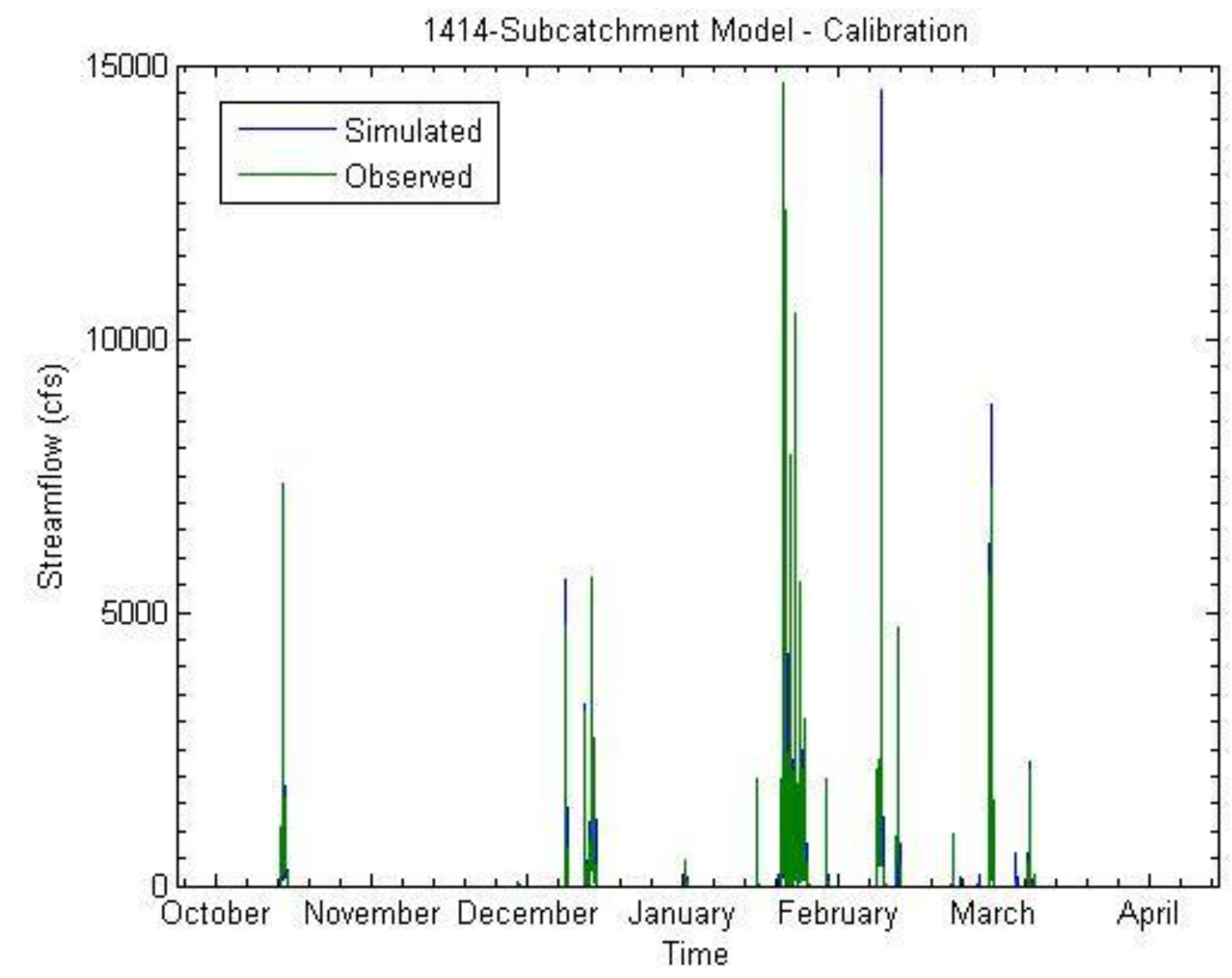

Figure 52: 1414-Subcatchment model, calibration time series. 


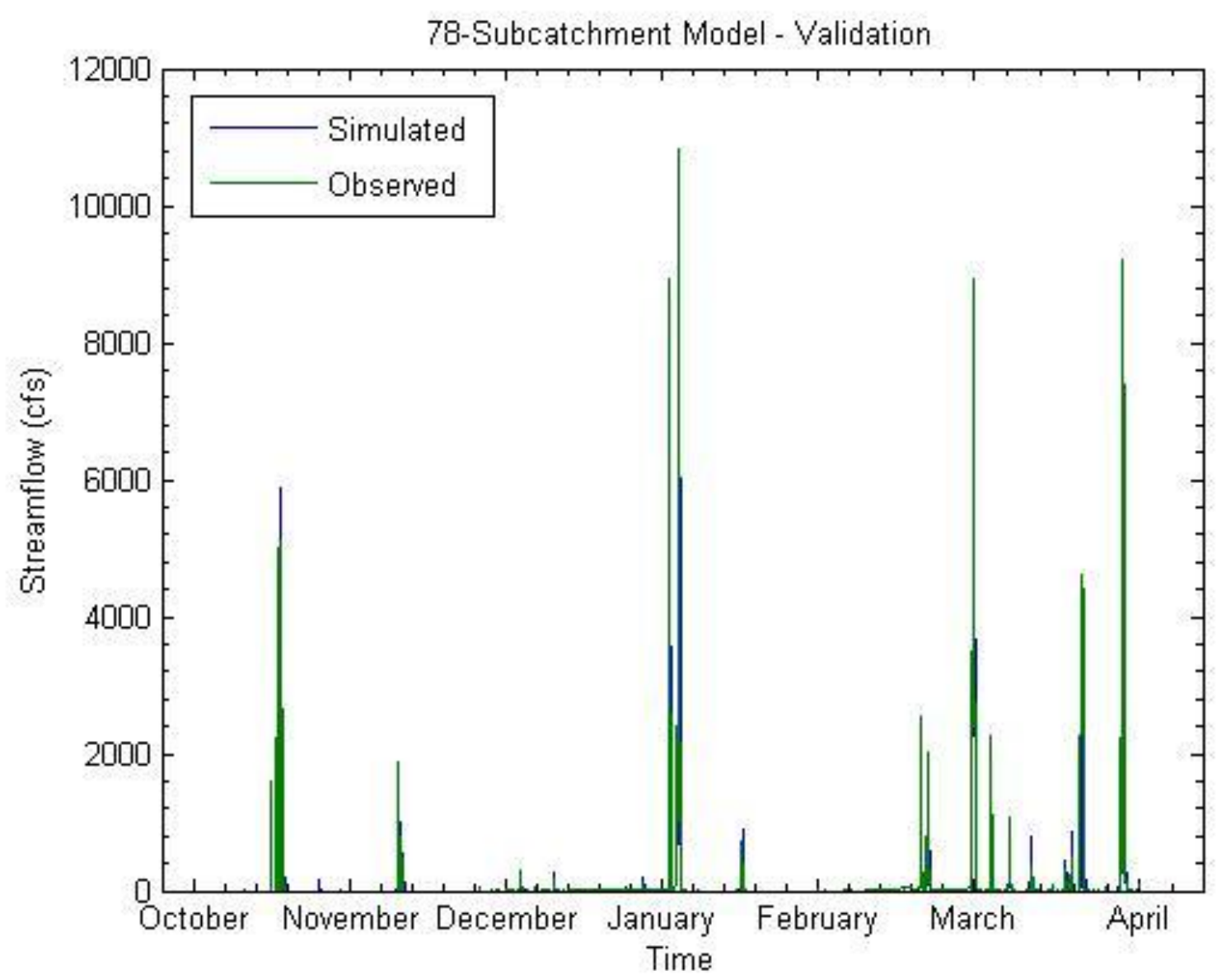

Figure 53: 78-Subcatchment model, validation time series. 


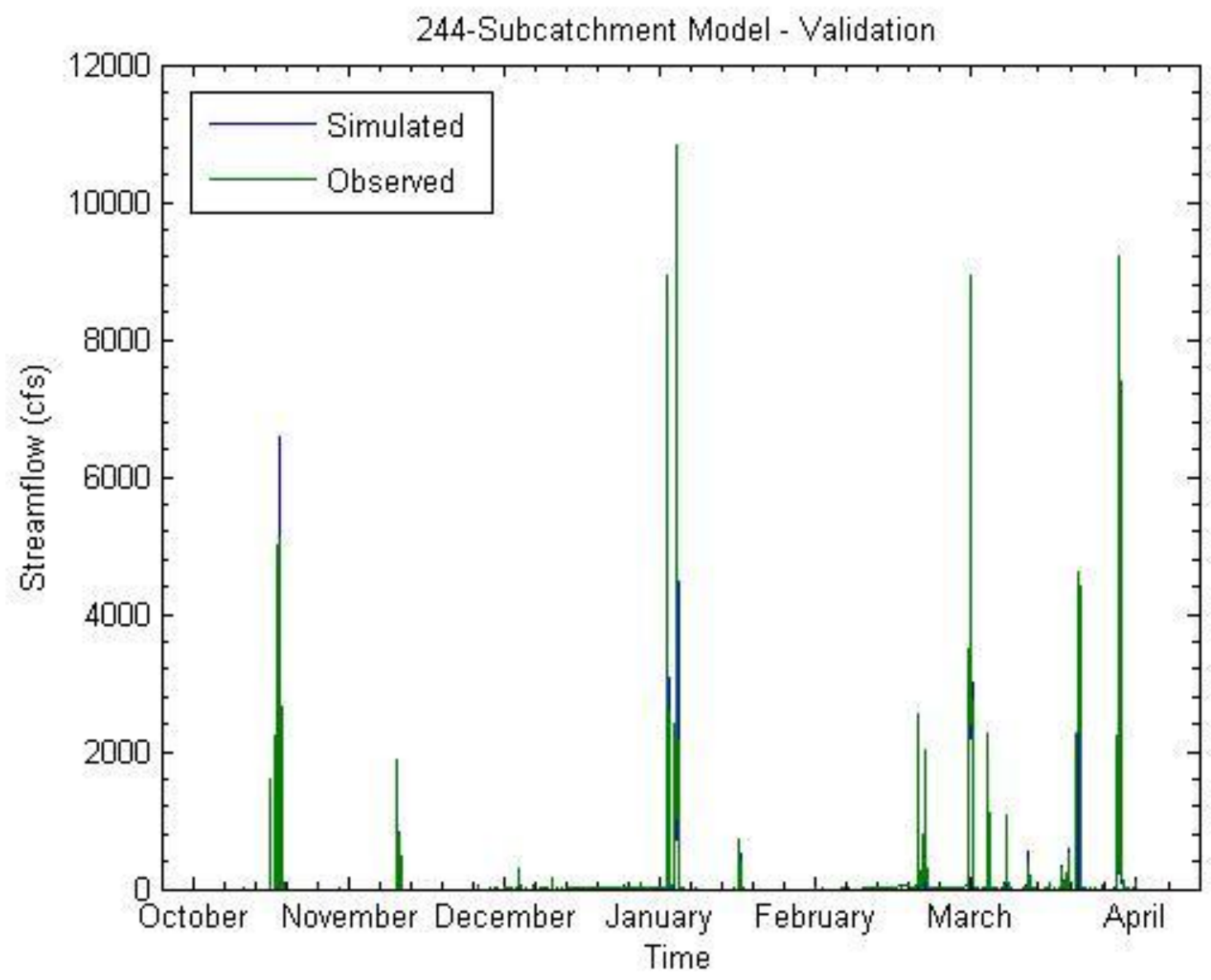

Figure 54: 244-Subcatchment model, validation time series. 


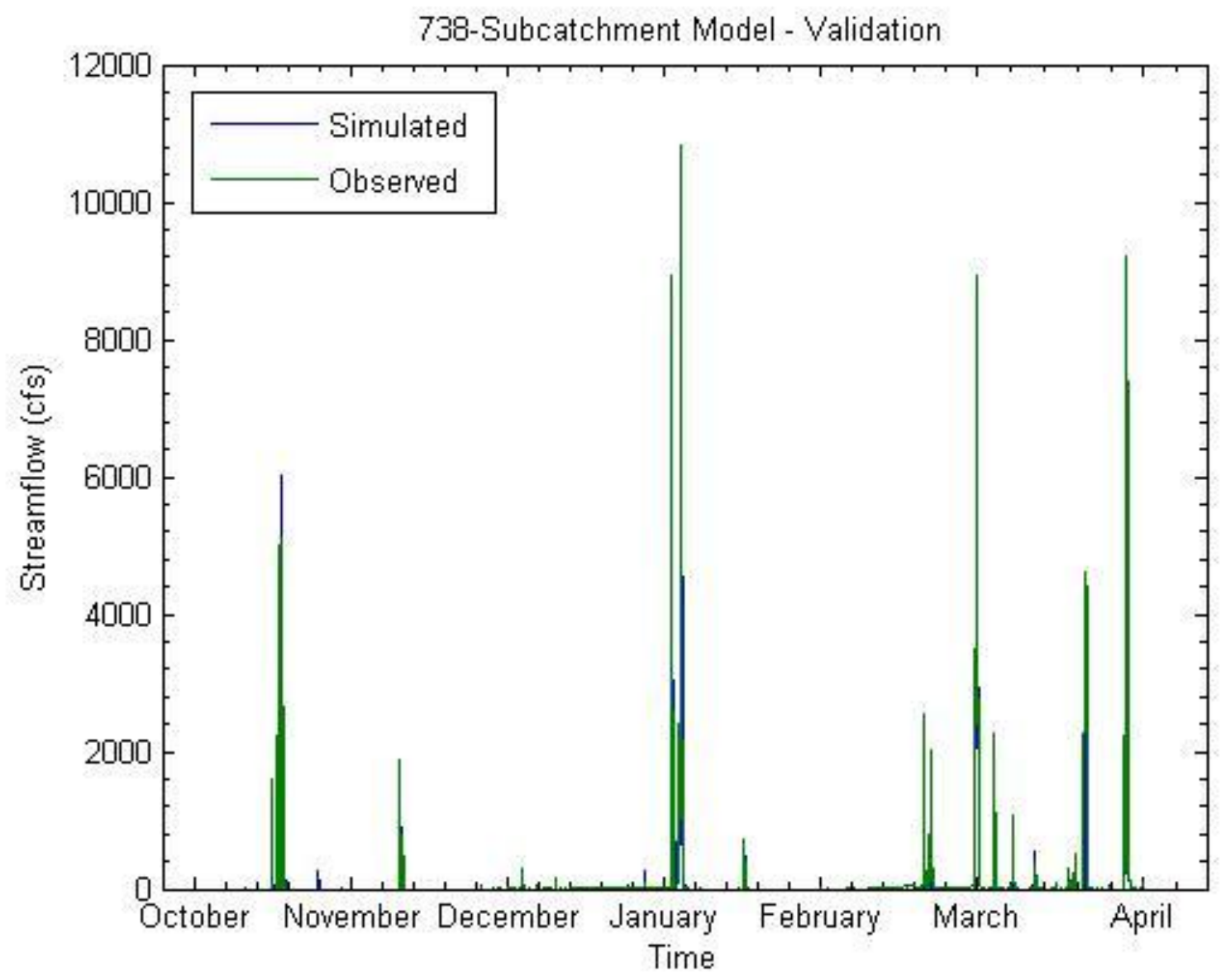

Figure 55: 738-Subcatchment model, validation time series. 


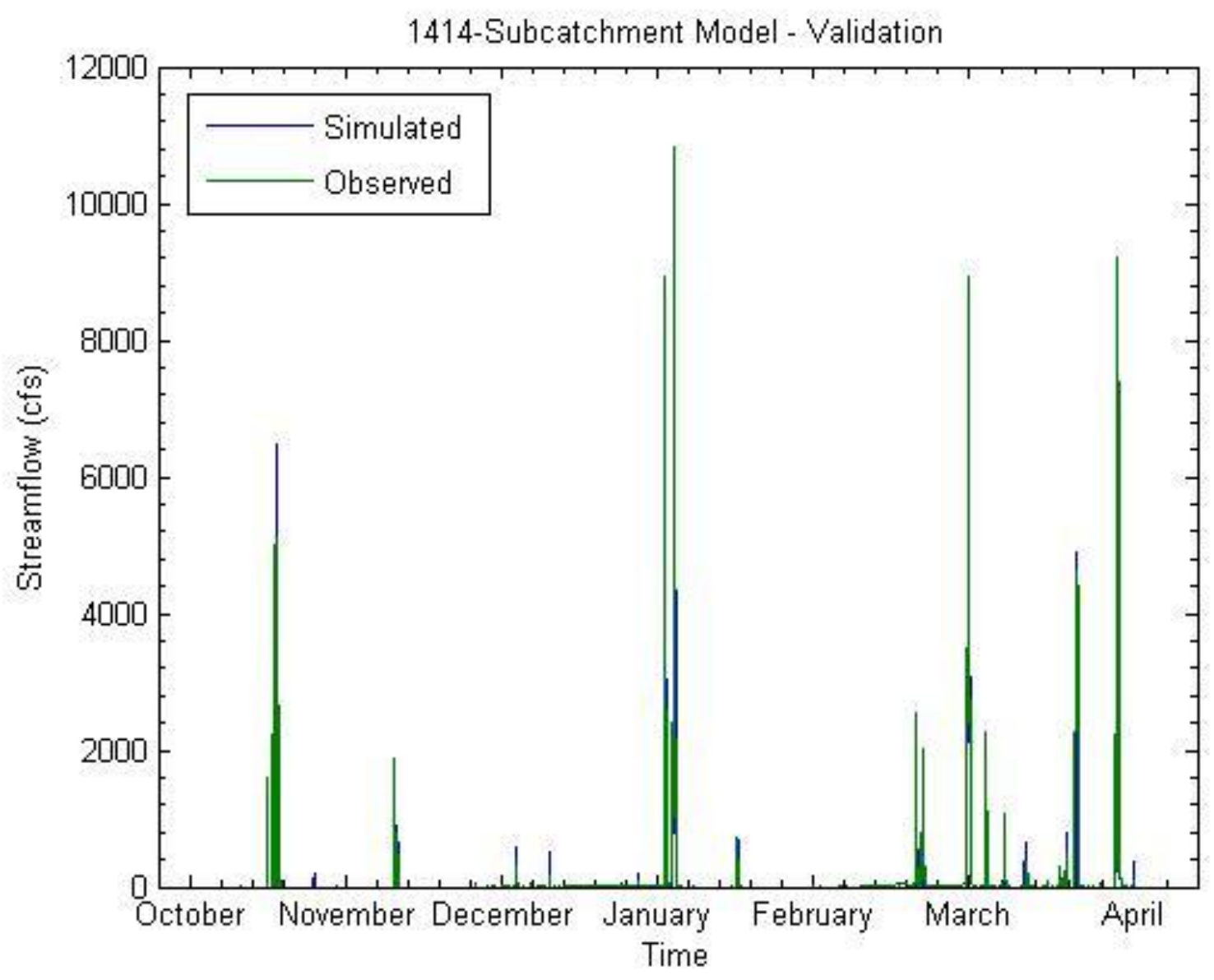

Figure 56: 1414-Subcatchment model, validation time series. 


\section{APPENDIX C: UNCERTAINTY ANALYSIS RESULTS}

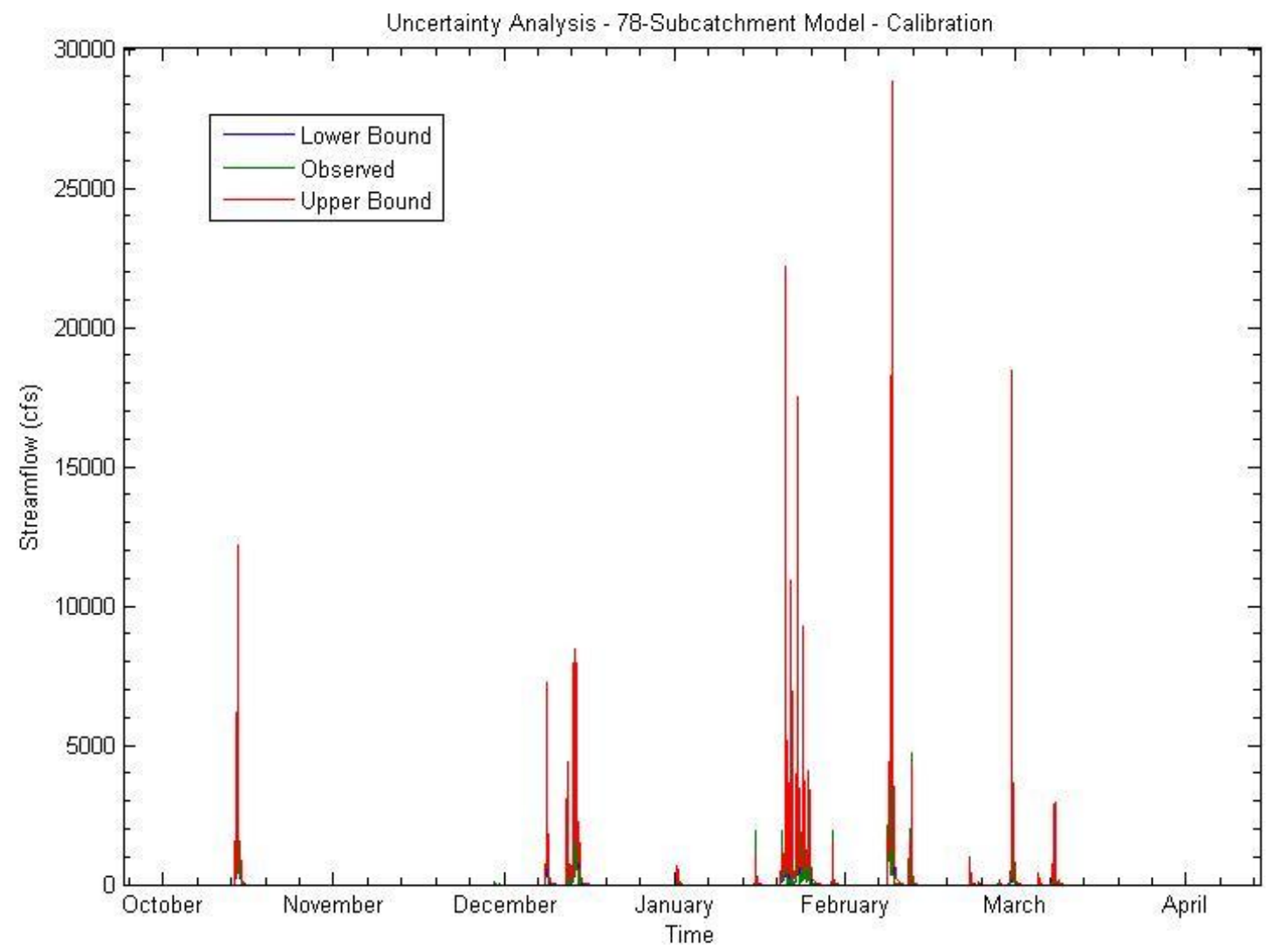

Figure 57: Uncertainty Analysis, 78-Subcatchment model, time series, calibration. 


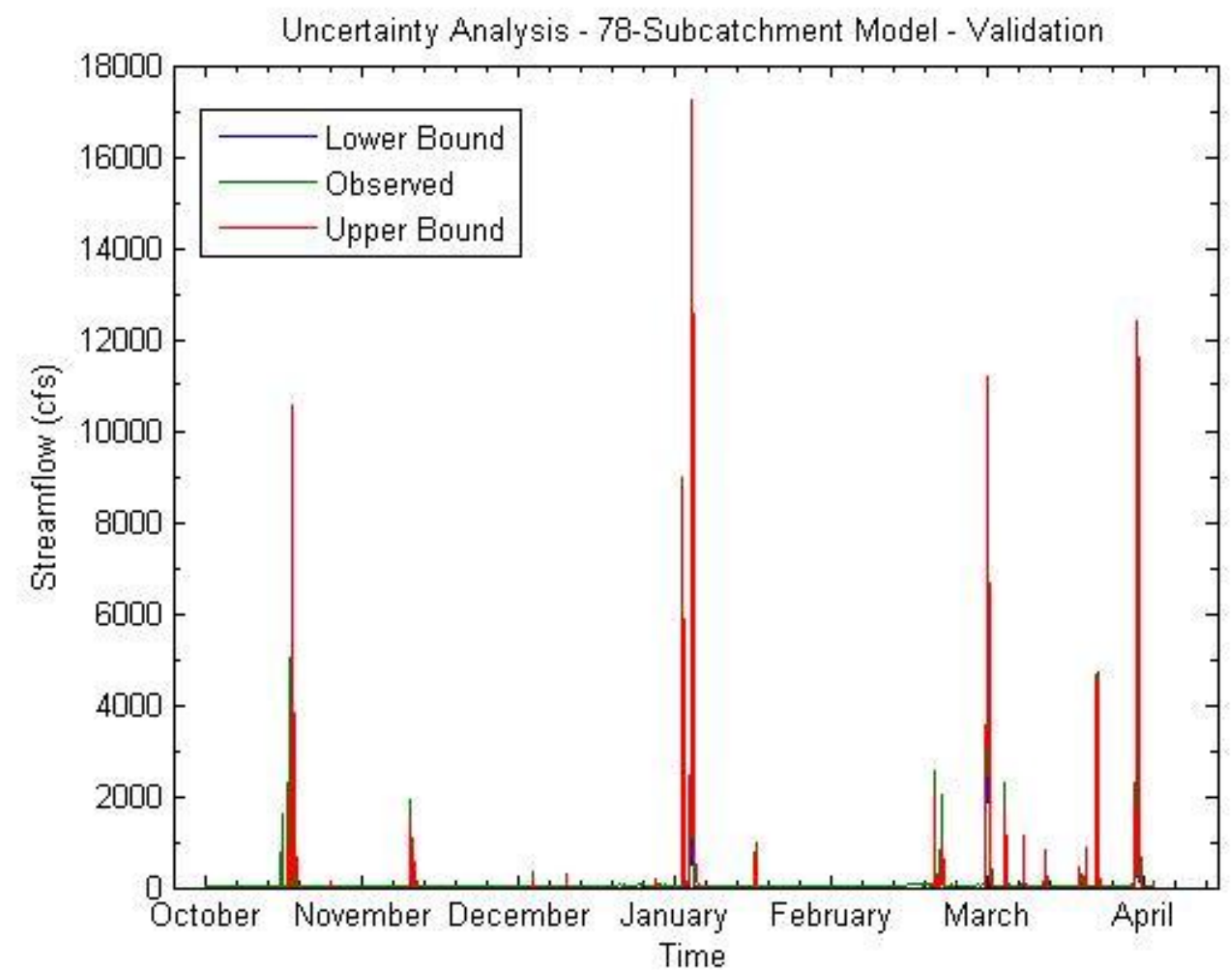

Figure 58: Uncertainty Analysis, 78-Subcatchment model, time series, validation. 


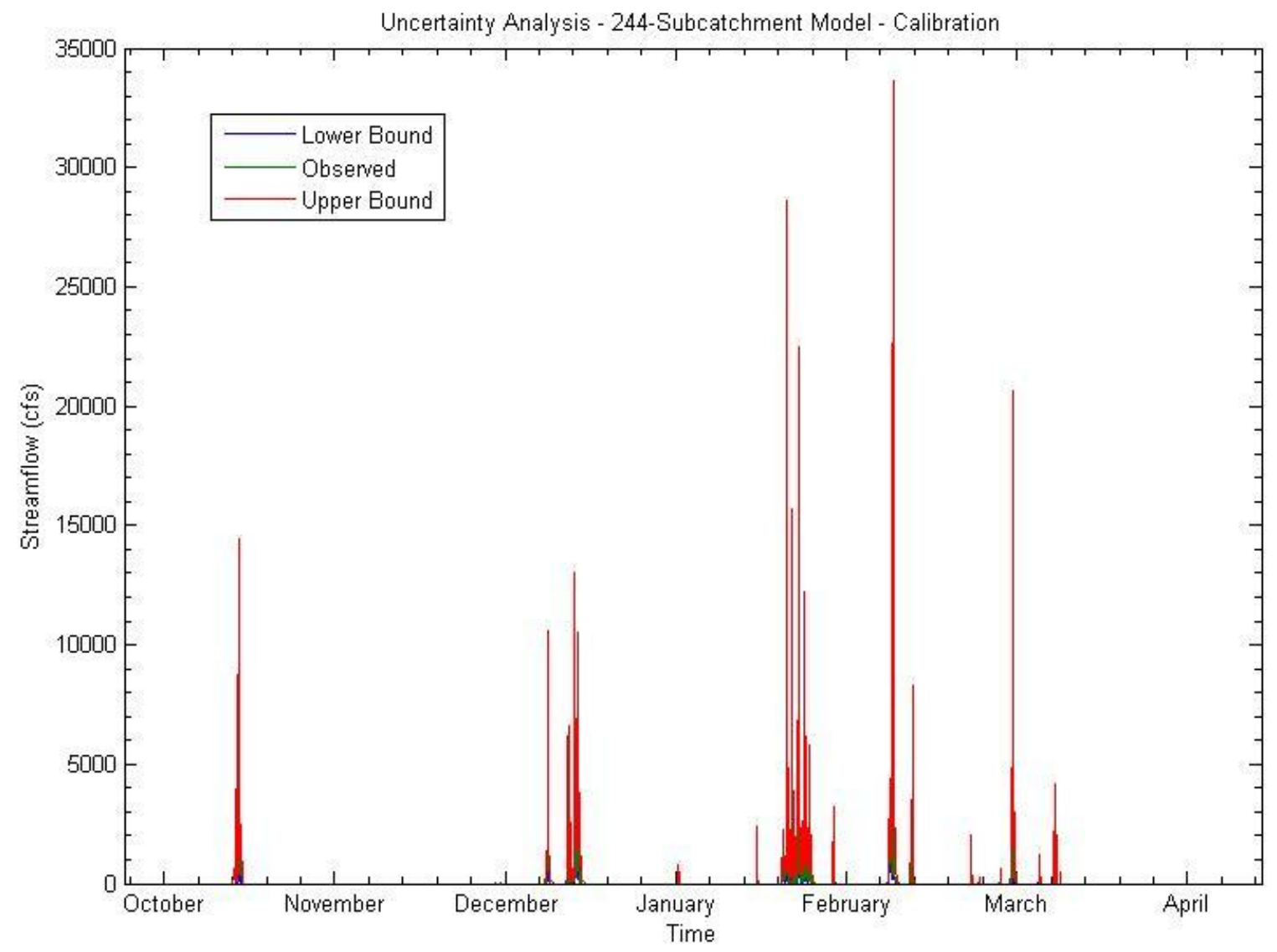

Figure 59: Uncertainty Analysis, 244-Subcatchment model, time series, calibration. 


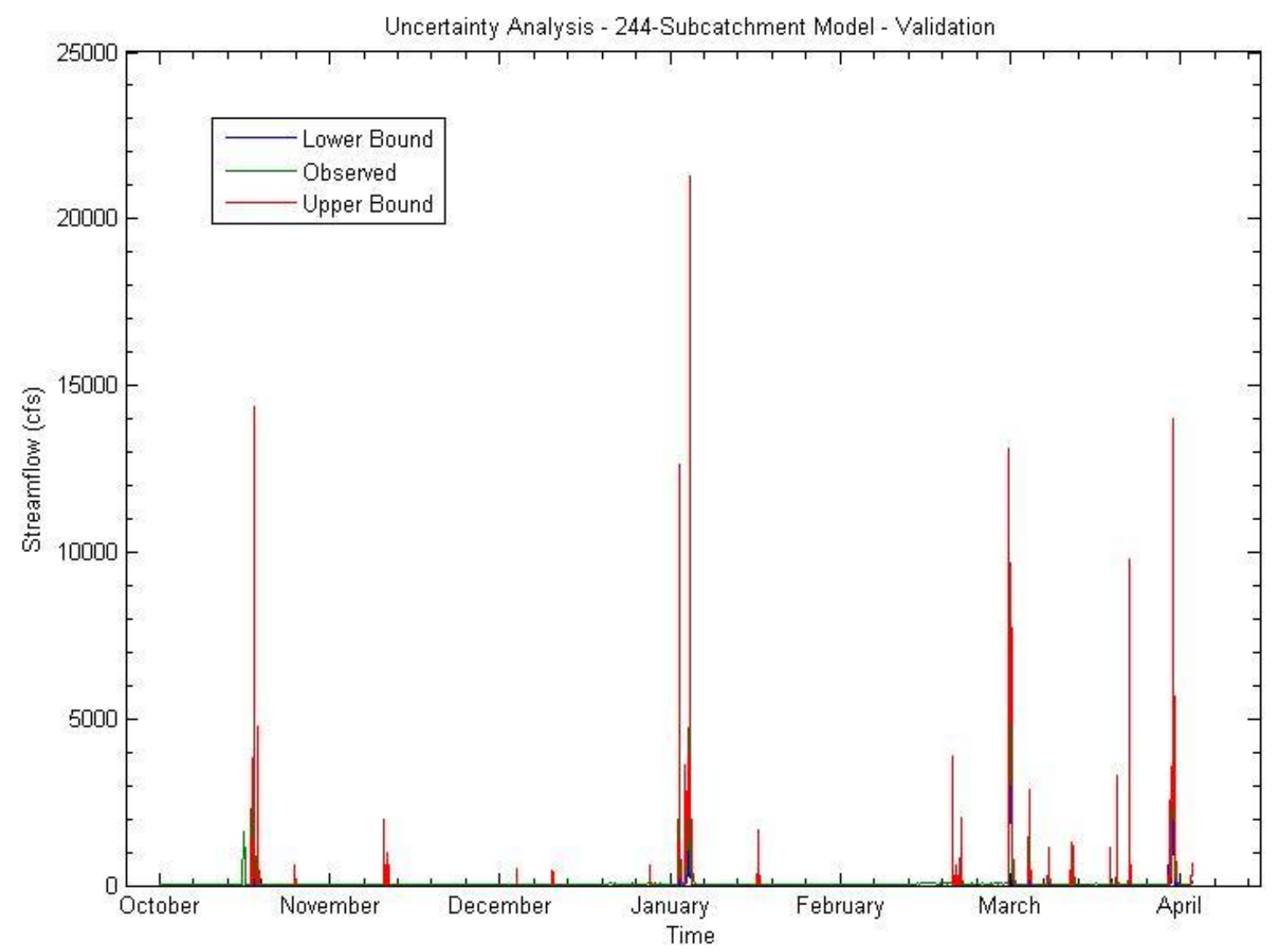

Figure 60: Uncertainty Analysis, 244-Subcatchment model, time series, validation. 


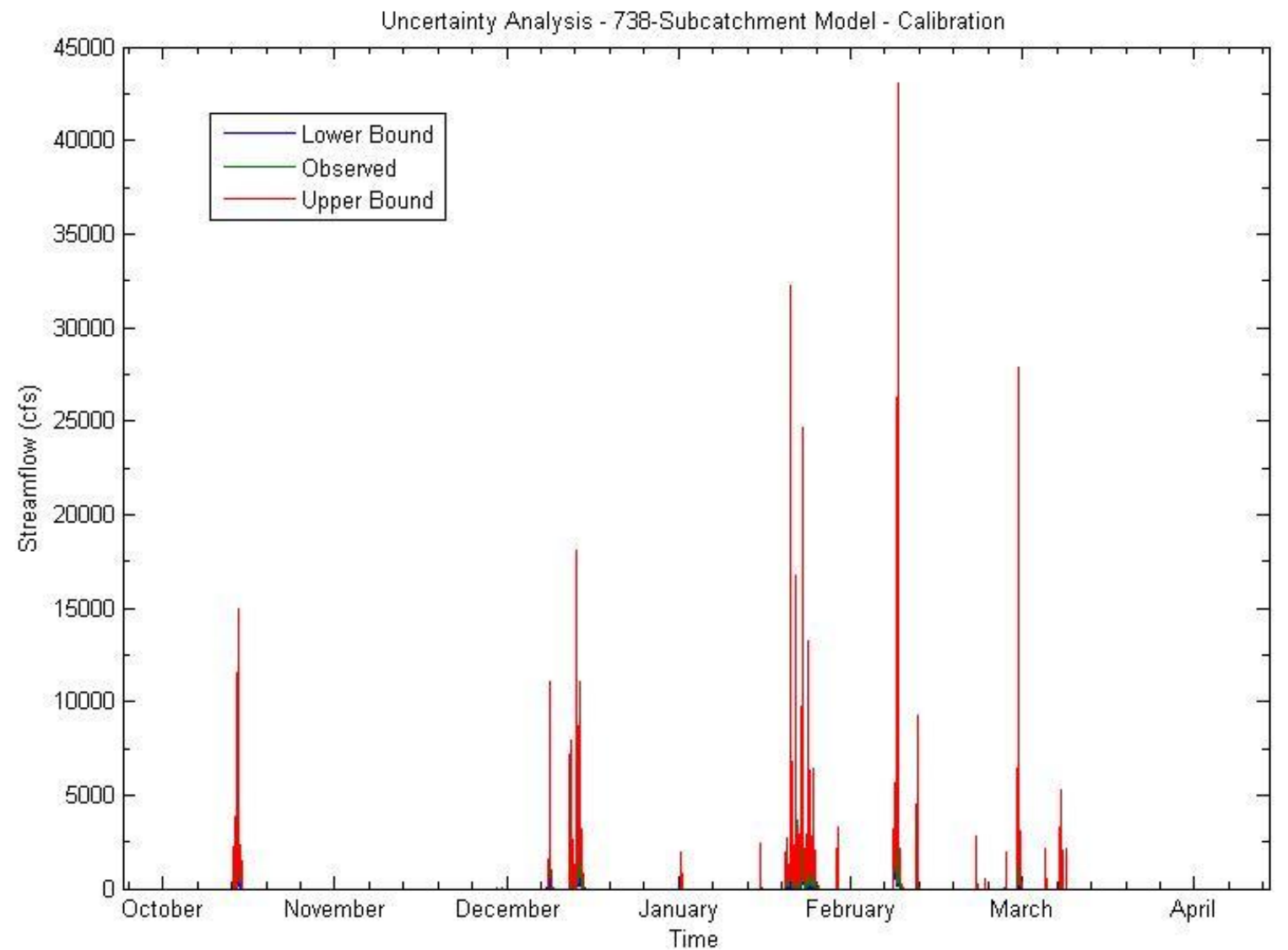

Figure 61: Uncertainty Analysis, 738-Subcatchment model, time series, calibration. 


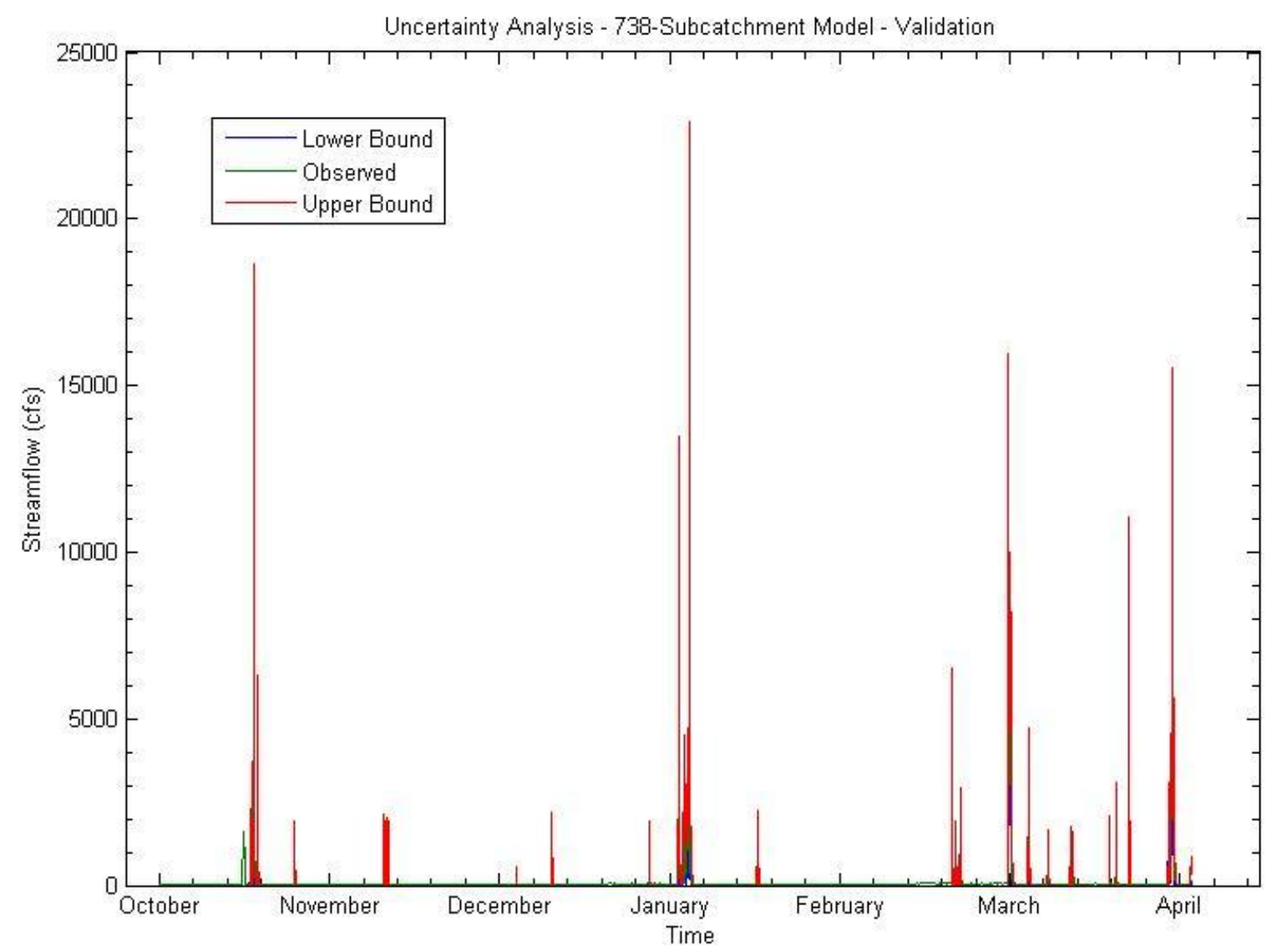

Figure 62: Uncertainty Analysis, 738-Subcatchment model, time series, validation. 


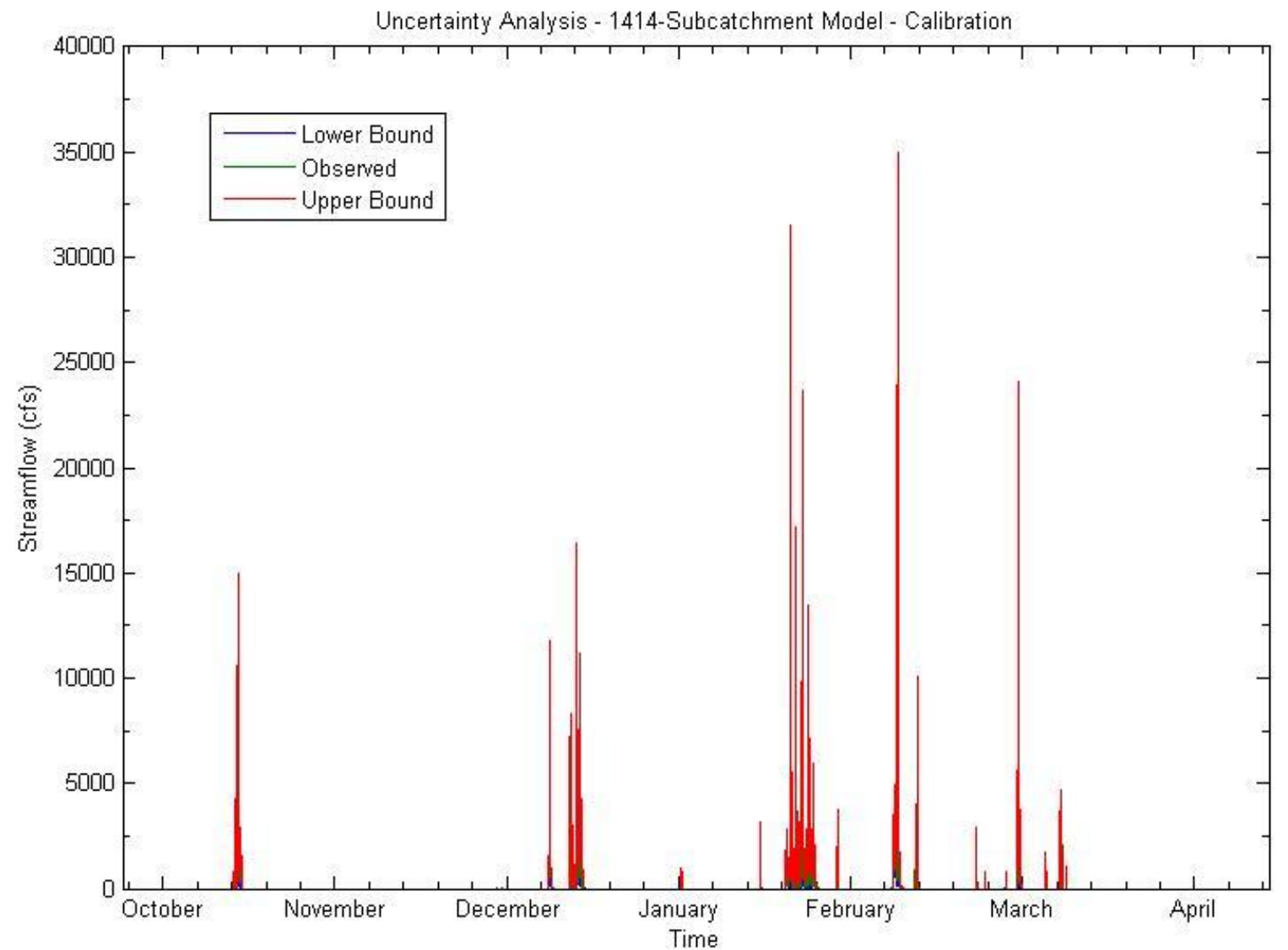

Figure 63: Uncertainty Analysis, 1414-Subcatchment model, time series, calibration. 


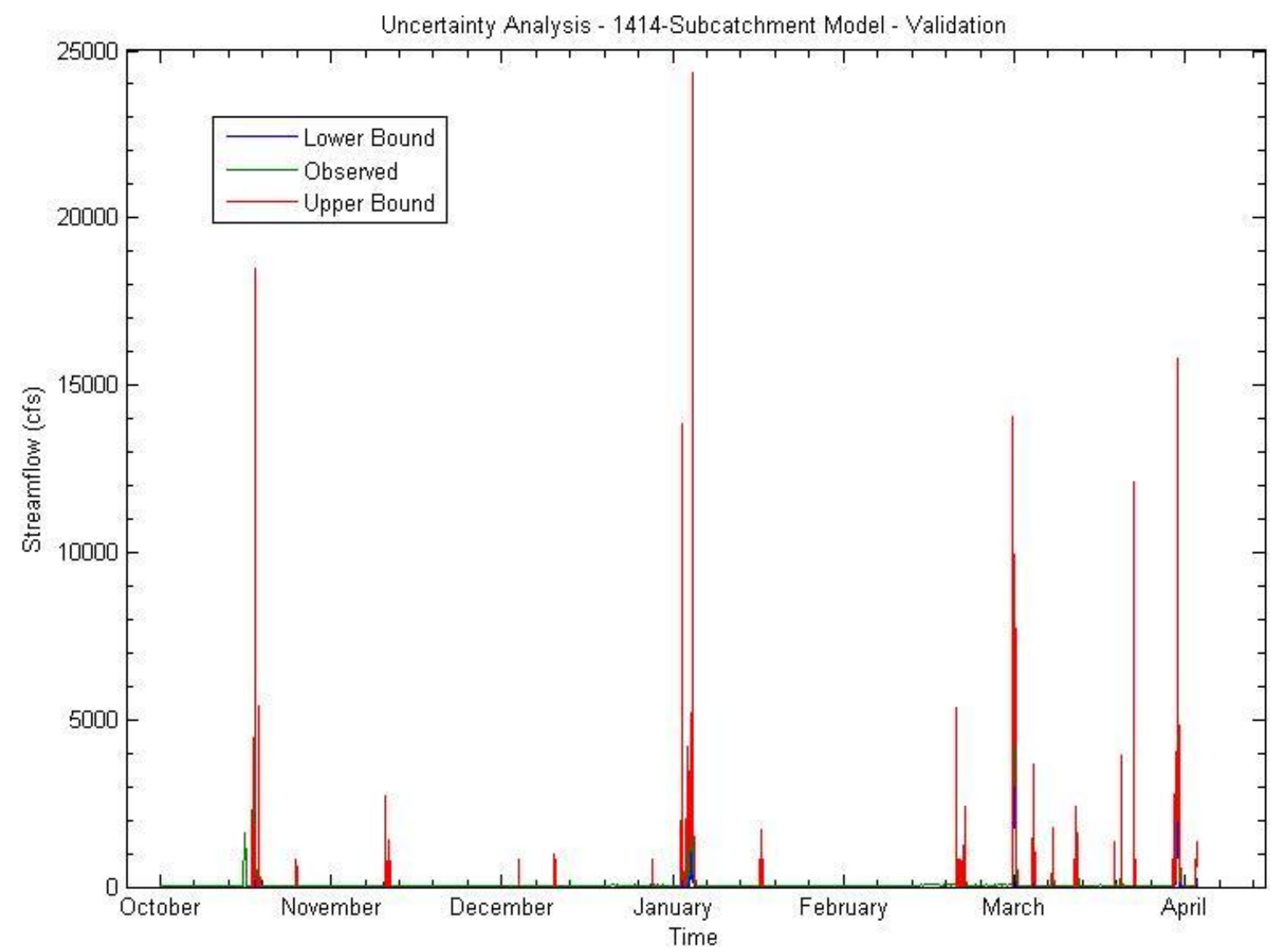

Figure 64: Uncertainty Analysis, 1414-Subcatchment model, time series, validation. 


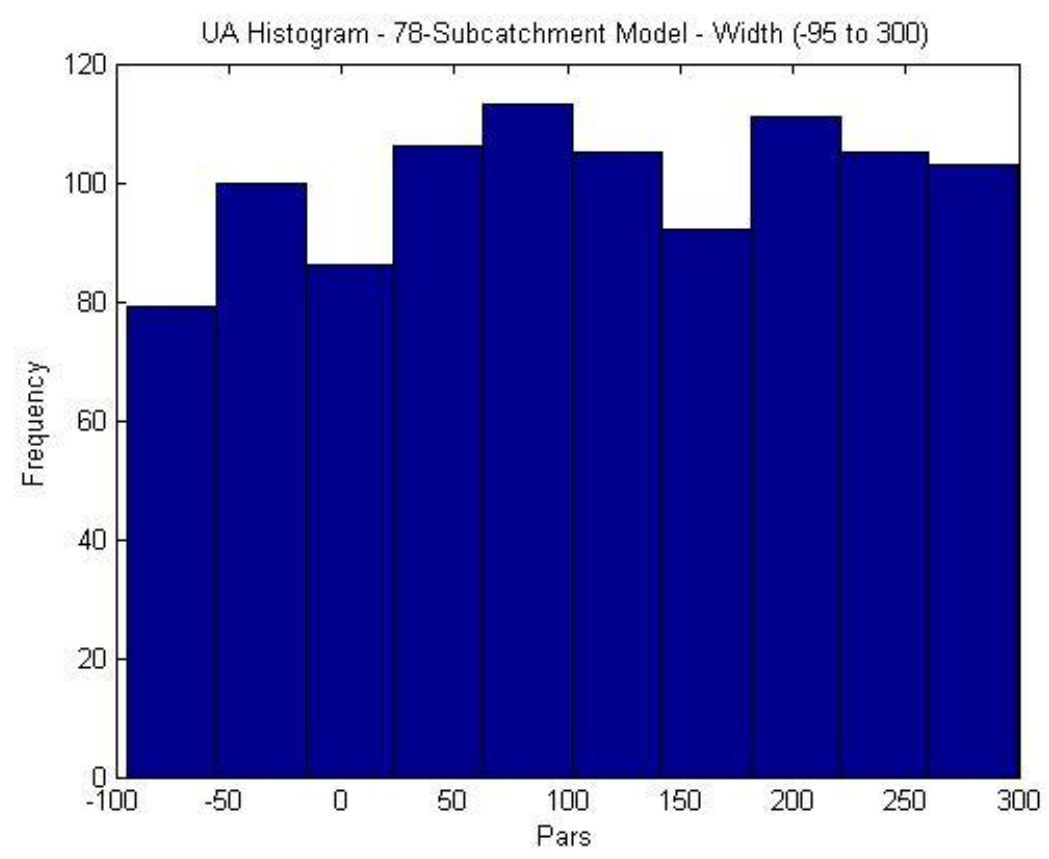

Figure 65: Uncertainty Analysis, 78-Subcatchment model, Width histogram.

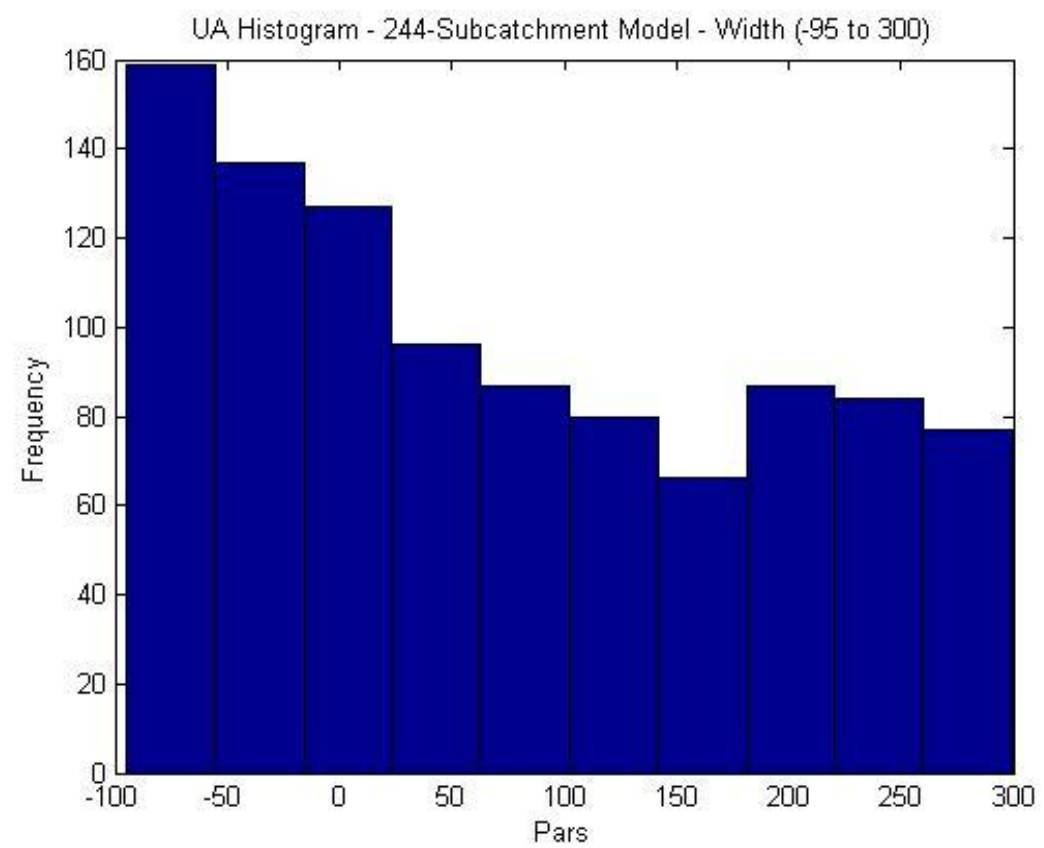

Figure 66: Uncertainty Analysis, 244-Subcatchment model, Width histogram. 


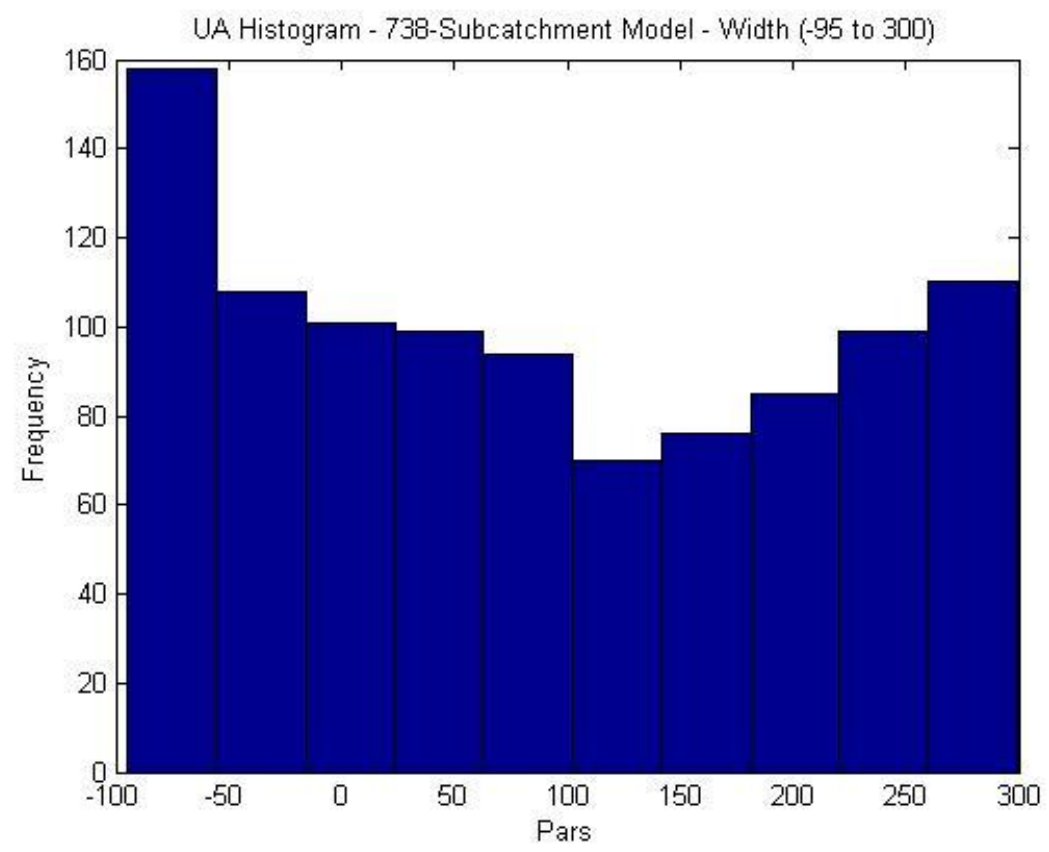

Figure 67: Uncertainty Analysis, 738-Subcatchment model, Width histogram.

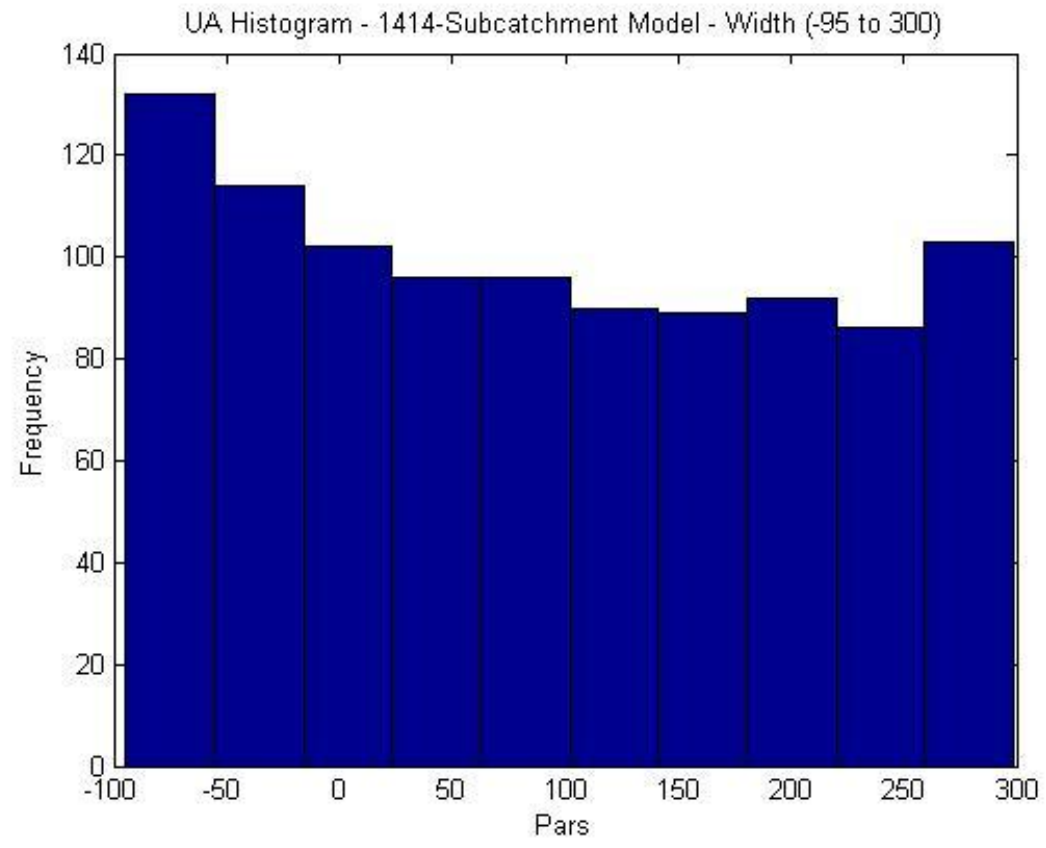

Figure 68: Uncertainty Analysis, 1414-Subcatchment model, Width histogram. 


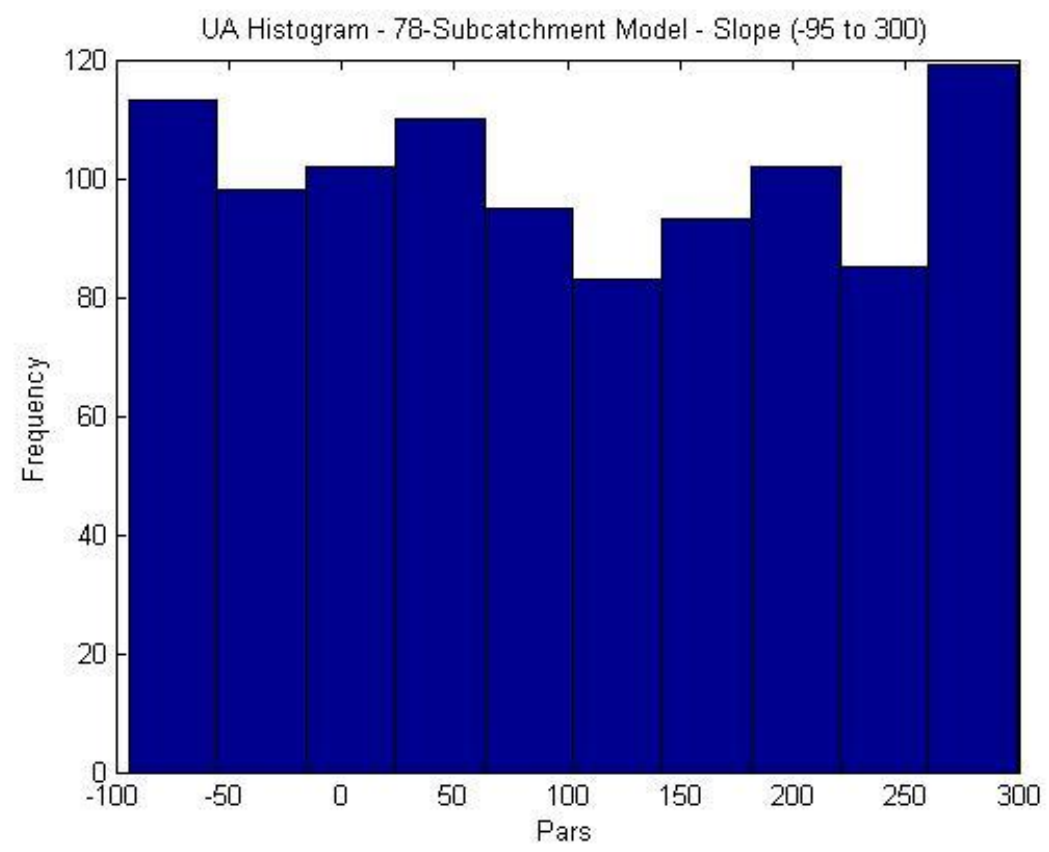

Figure 69: Uncertainty Analysis, 78-Subcatchment model, Slope histogram.

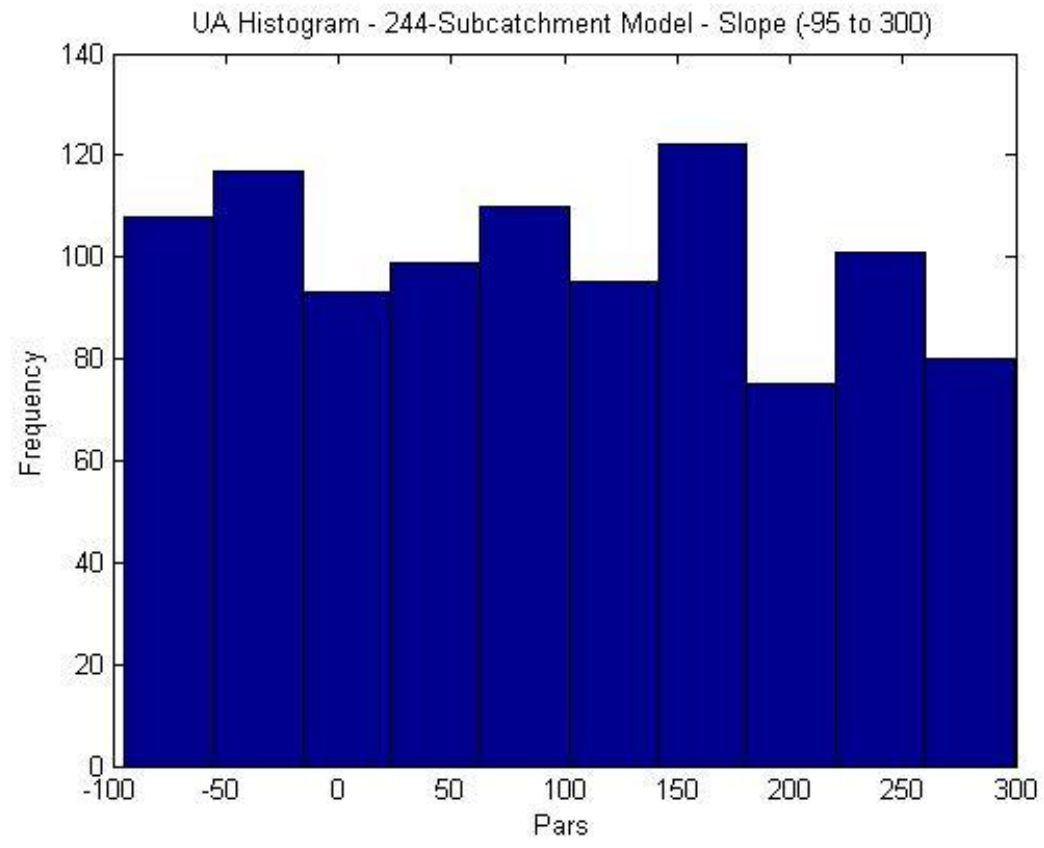

Figure 70: Uncertainty Analysis, 244-Subcatchment model, Slope histogram. 


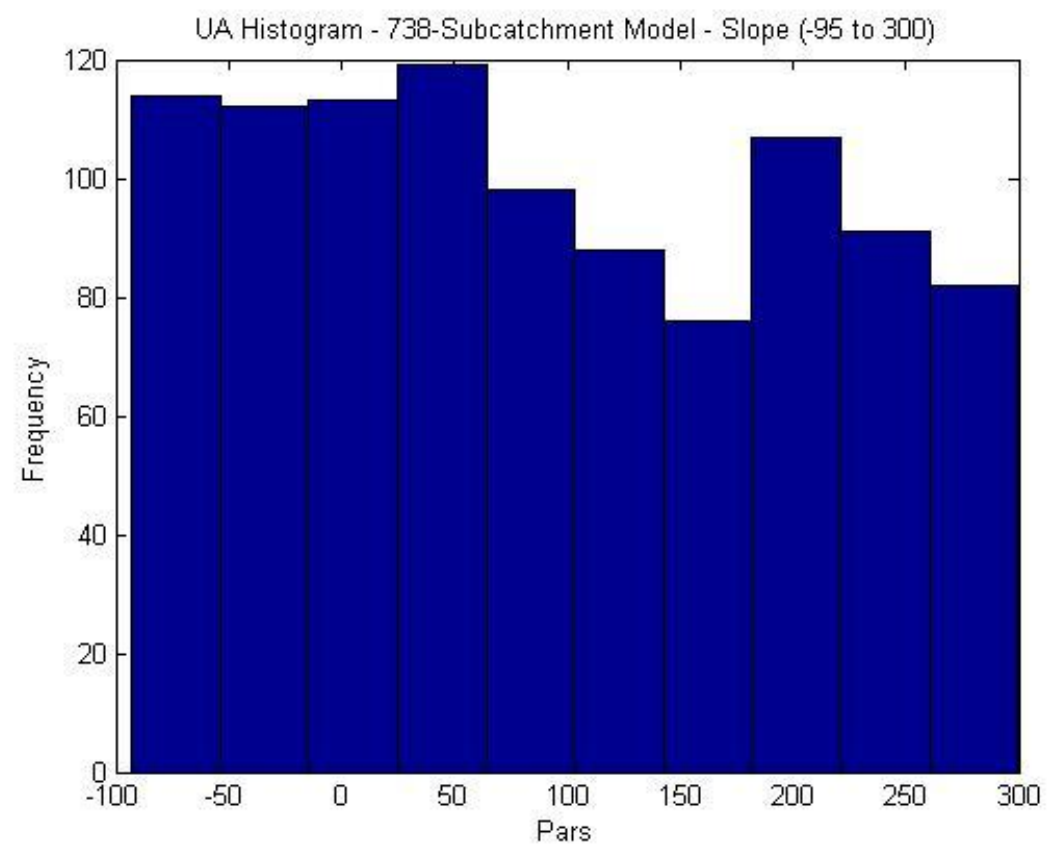

Figure 71: Uncertainty Analysis, 738-Subcatchment model, Slope histogram.

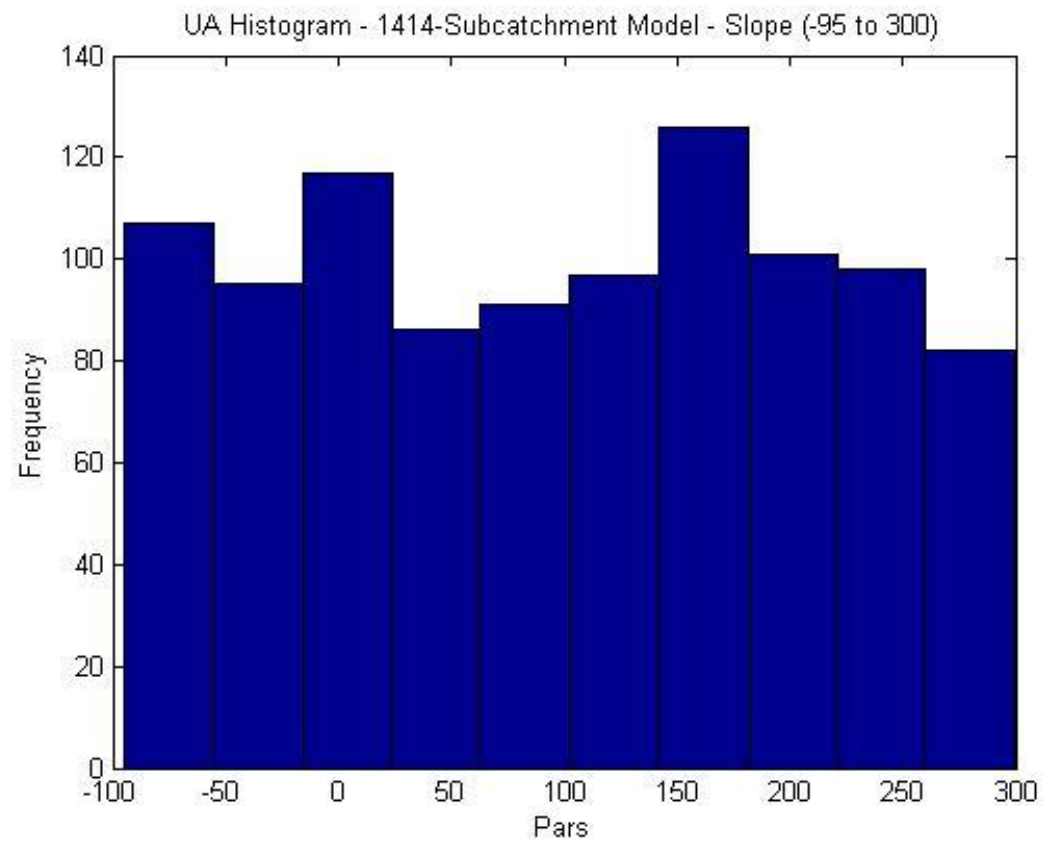

Figure 72: Uncertainty Analysis, 1414-Subcatchment model, Slope histogram. 


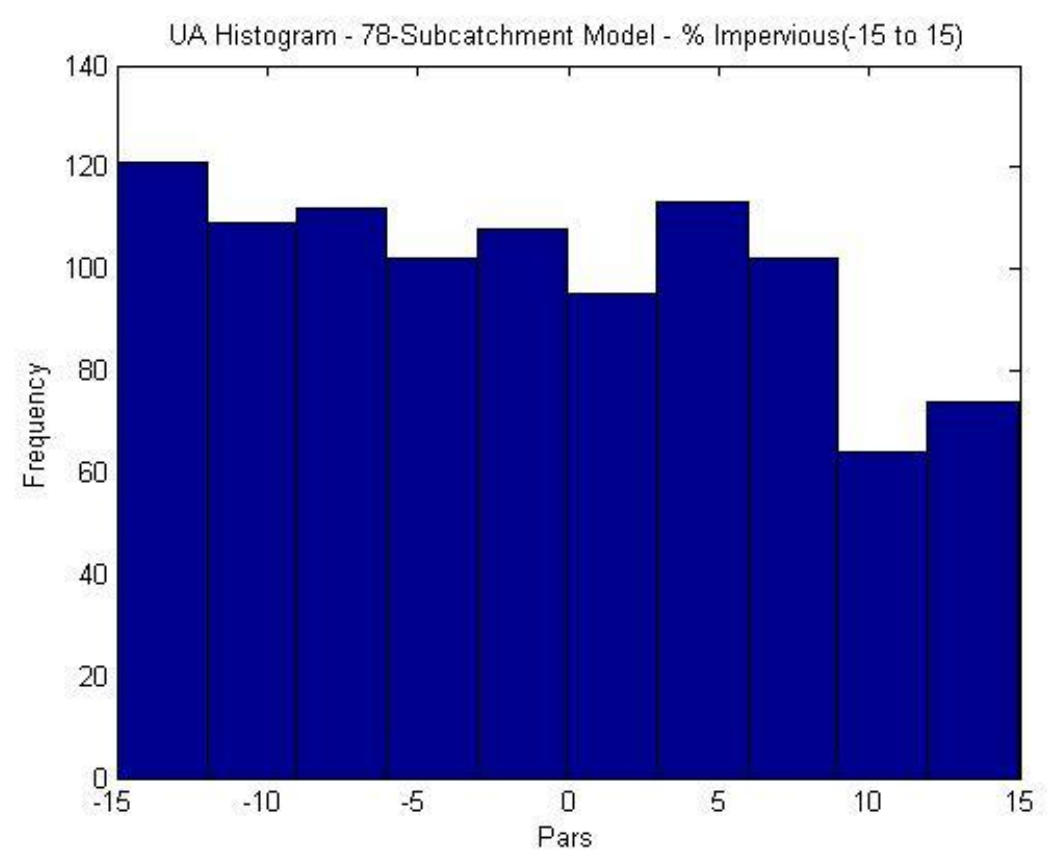

Figure 73: Uncertainty Analysis, 78-Subcatchment model, Percent Impervious histogram.

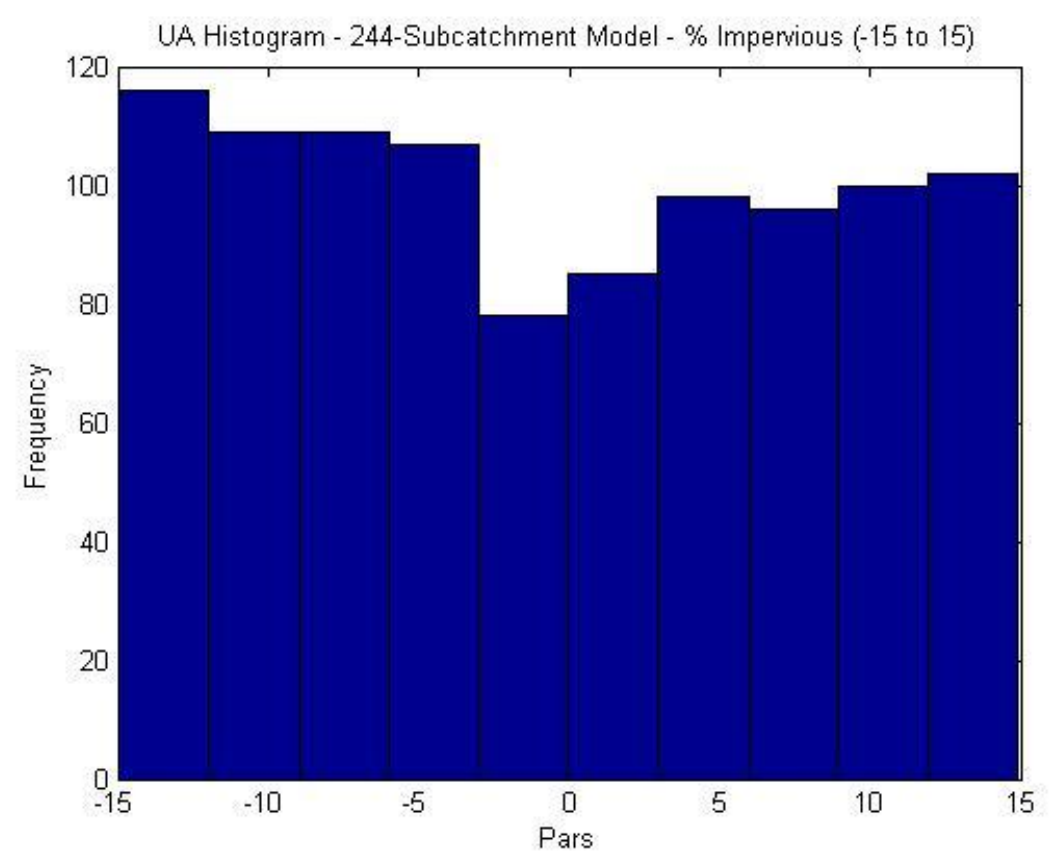

Figure 74: Uncertainty Analysis, 244-Subcatchment model, Percent Impervious histogram. 


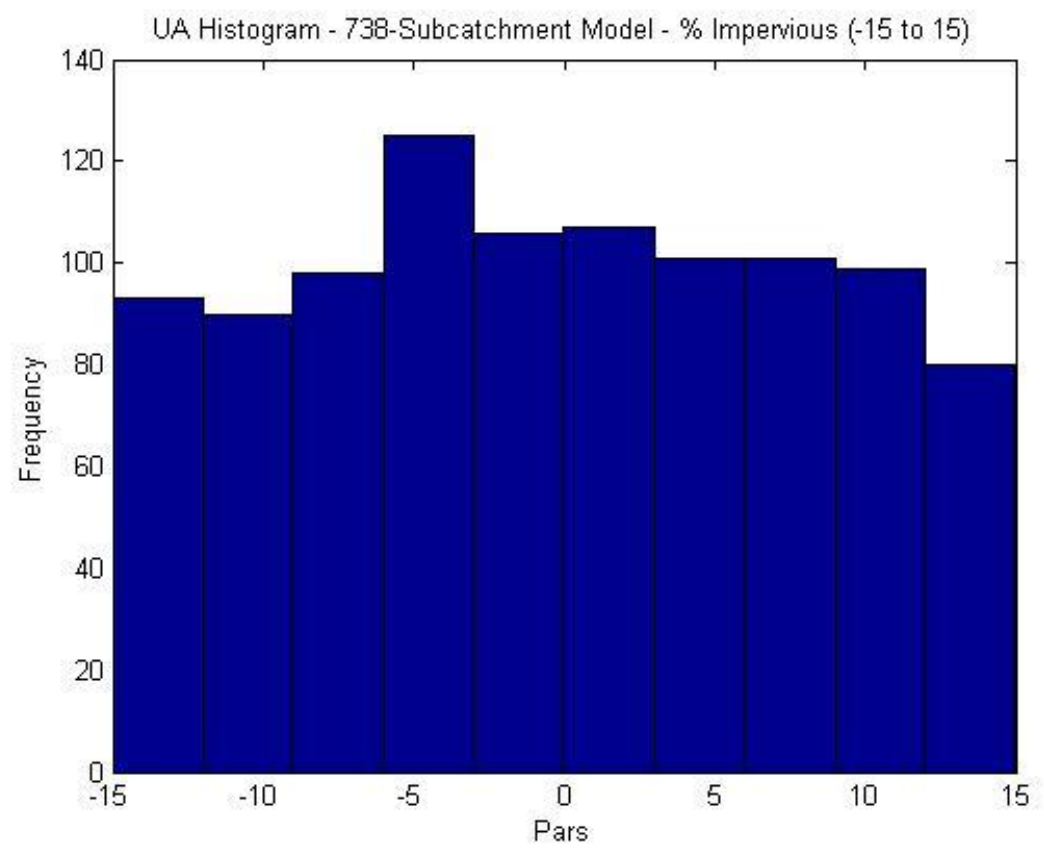

Figure 75: Uncertainty Analysis, 738-Subcatchment model, Percent Impervious histogram.

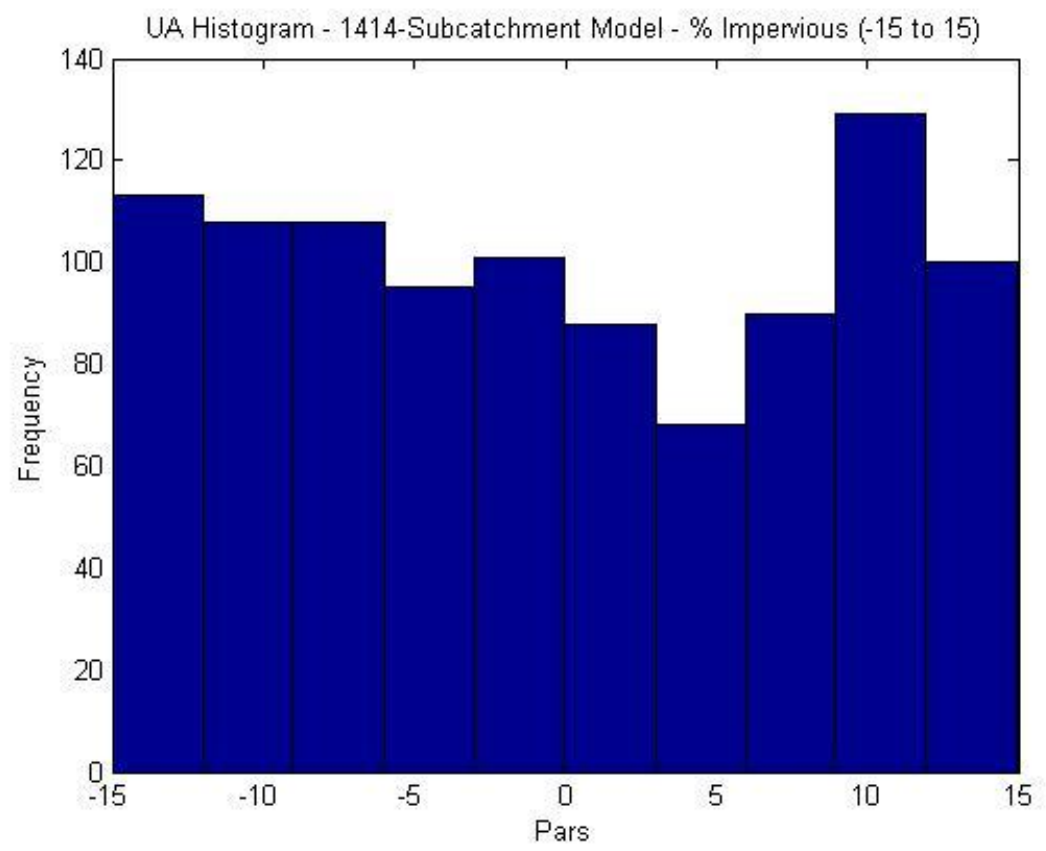

Figure 76: Uncertainty Analysis, 1414-Subcatchment model, Percent Impervious histogram. 


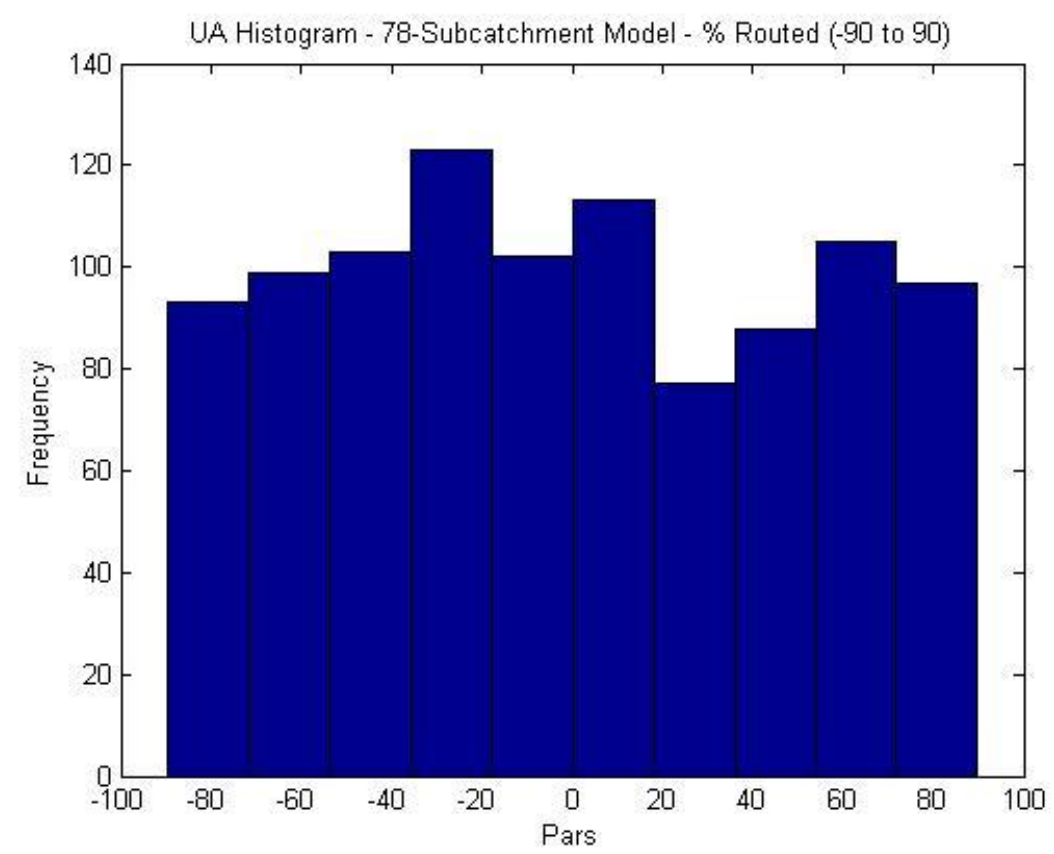

Figure 77: Uncertainty Analysis, 78-Subcatchment model, Percent Routed histogram.

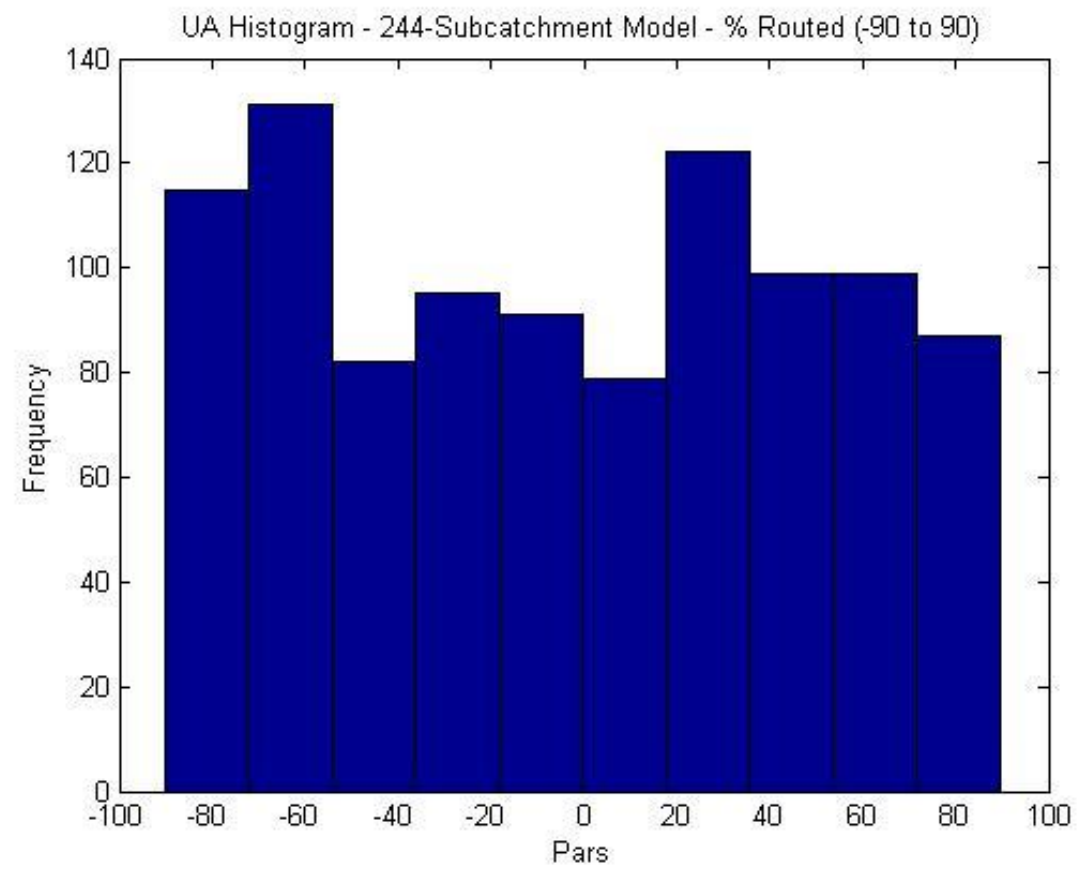

Figure 78: Uncertainty Analysis, 244-Subcatchment model, Percent Routed histogram. 


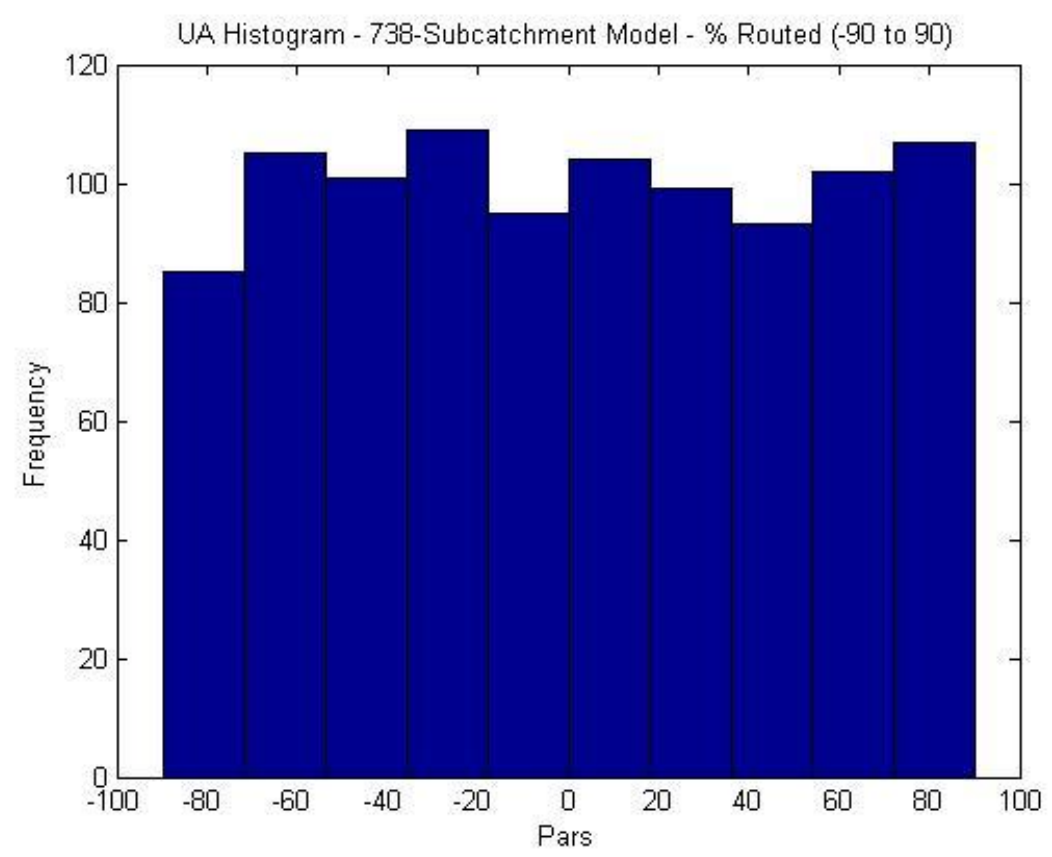

Figure 79: Uncertainty Analysis, 738-Subcatchment model, Percent Routed histogram.

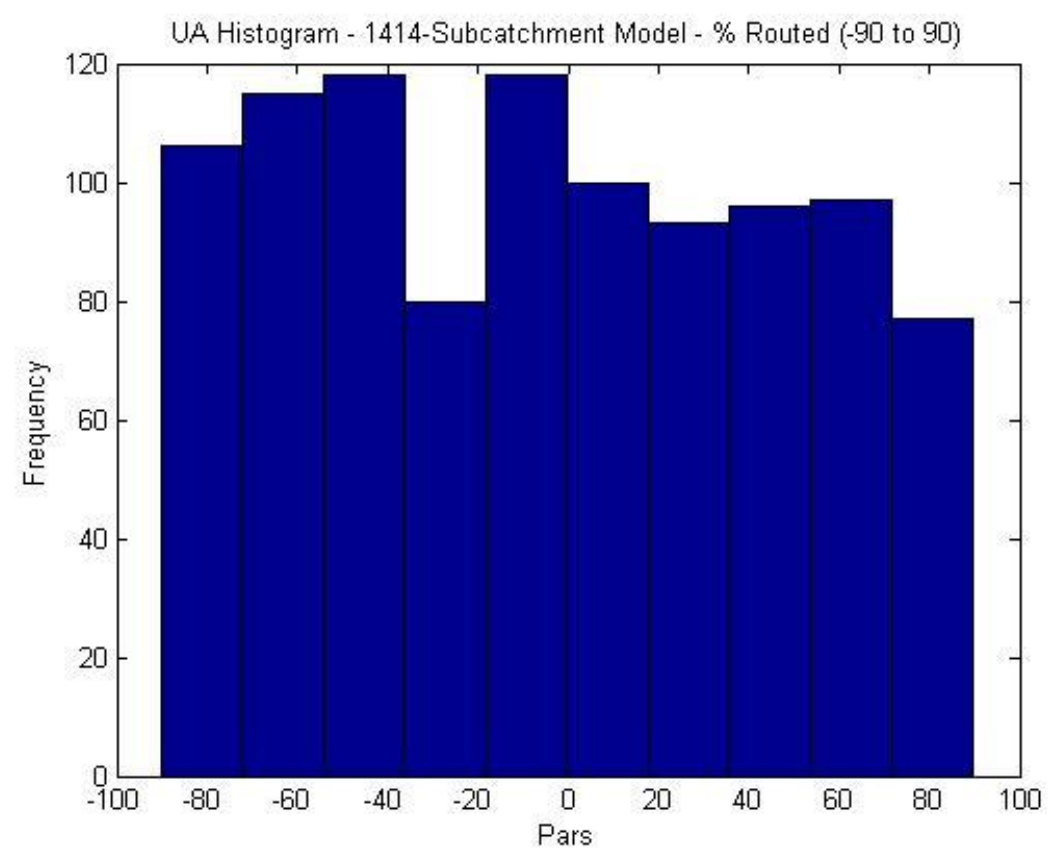

Figure 80: Uncertainty Analysis, 1414-Subcatchment model, Percent Routed histogram. 


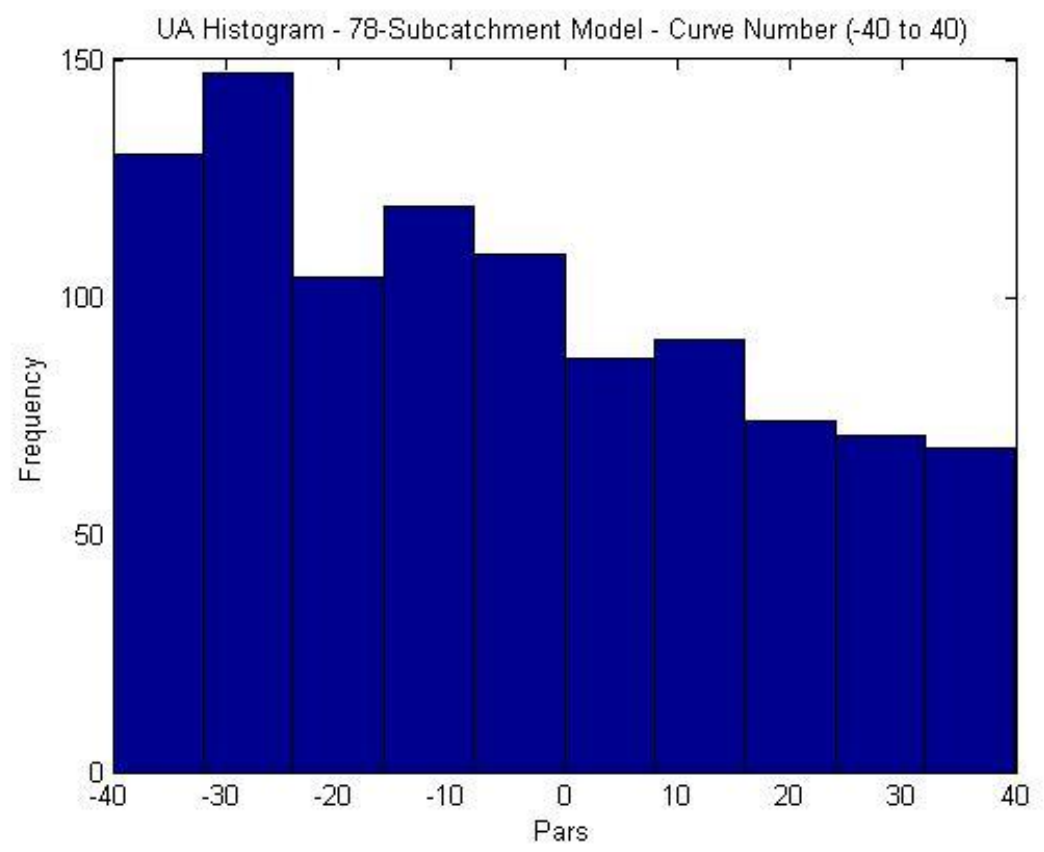

Figure 81: Uncertainty Analysis, 78-Subcatchment model, Curve Number histogram.

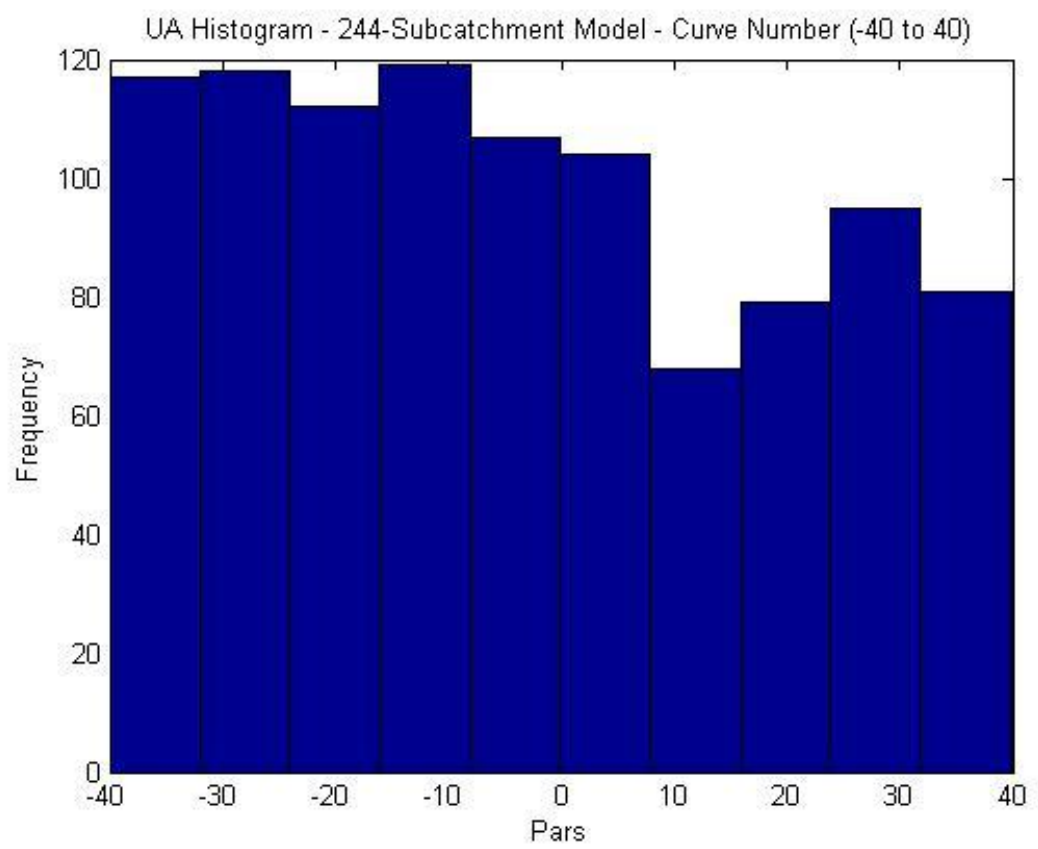

Figure 82: Uncertainty Analysis, 244-Subcatchment model, Curve Number histogram. 


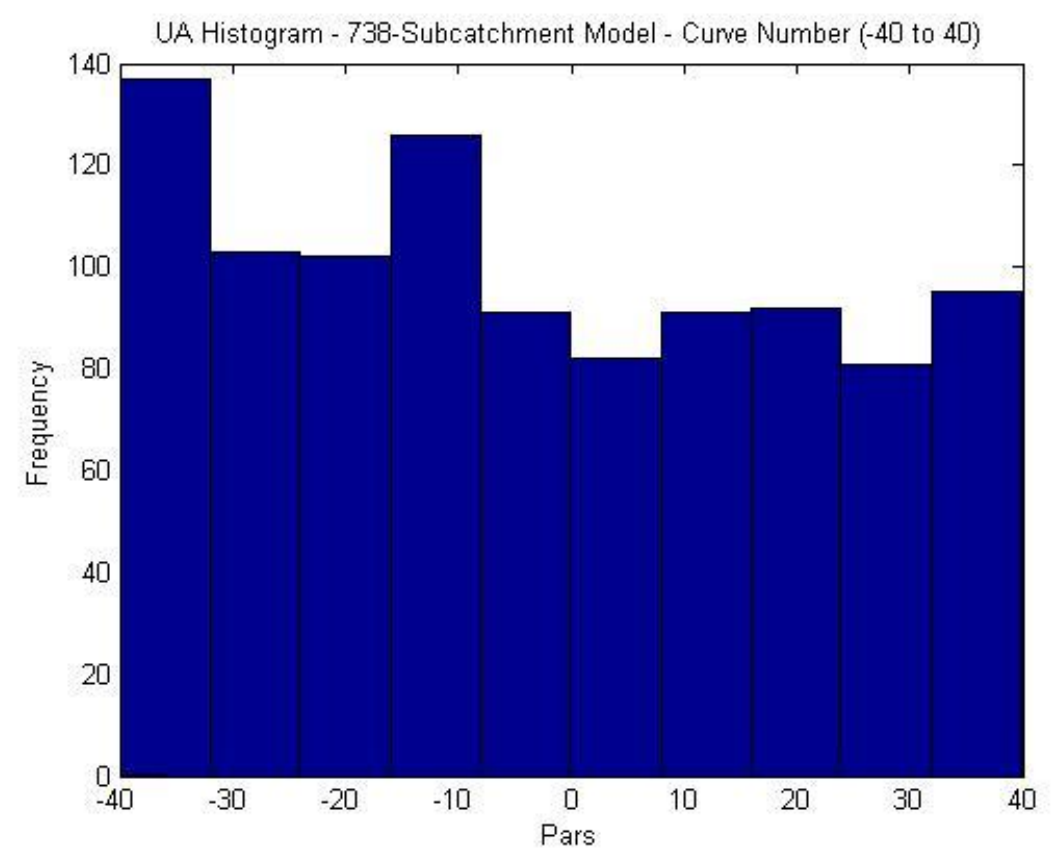

Figure 83: Uncertainty Analysis, 738-Subcatchment model, Curve Number histogram.

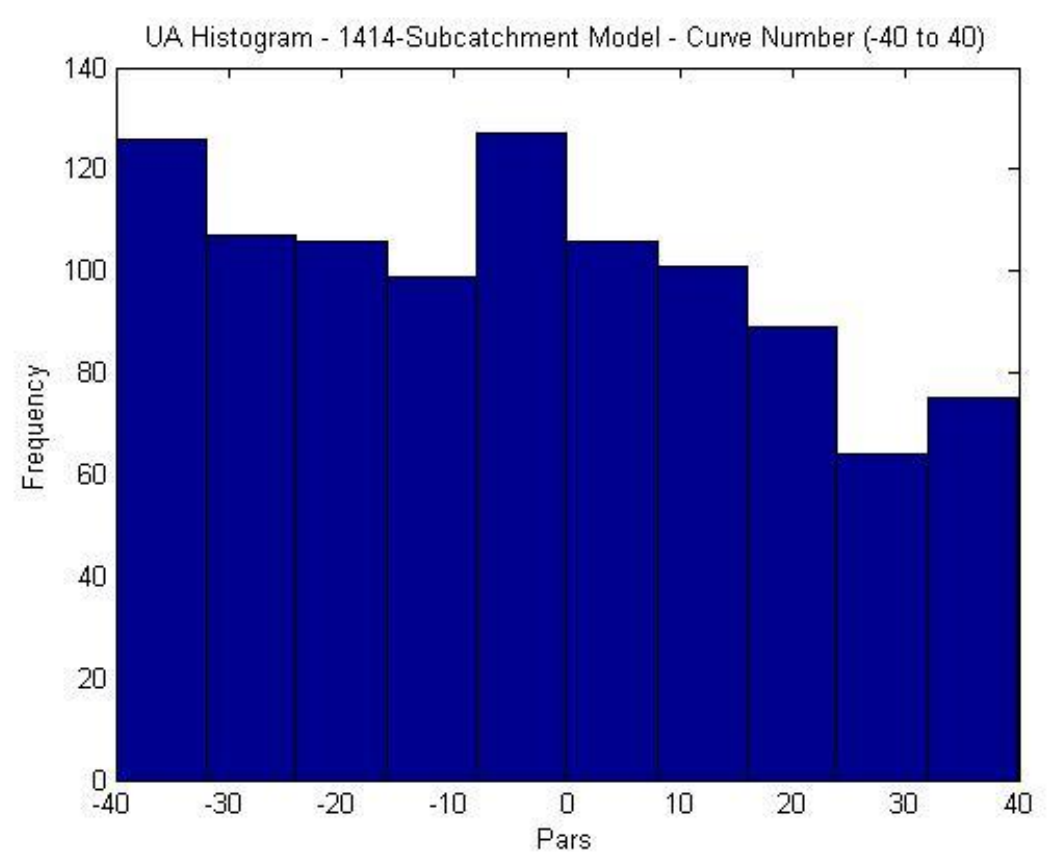

Figure 84: Uncertainty Analysis, 1414-Subcatchment model, Curve Number histogram. 
APPENDIX D: LID IMPLEMENTATION RESULTS 


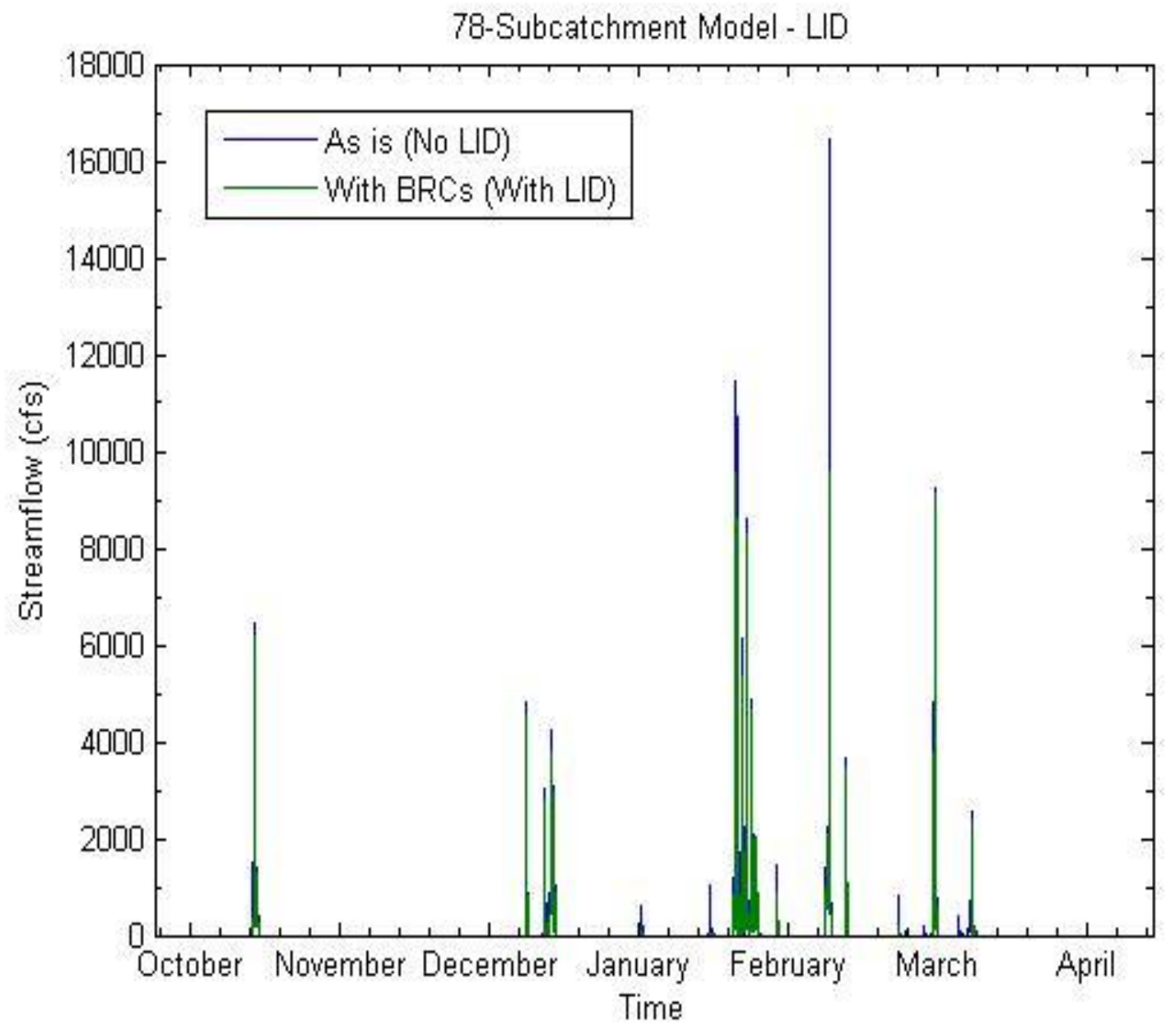

Figure 85: 78-Subcatchment model, with LID, calibration time series. 


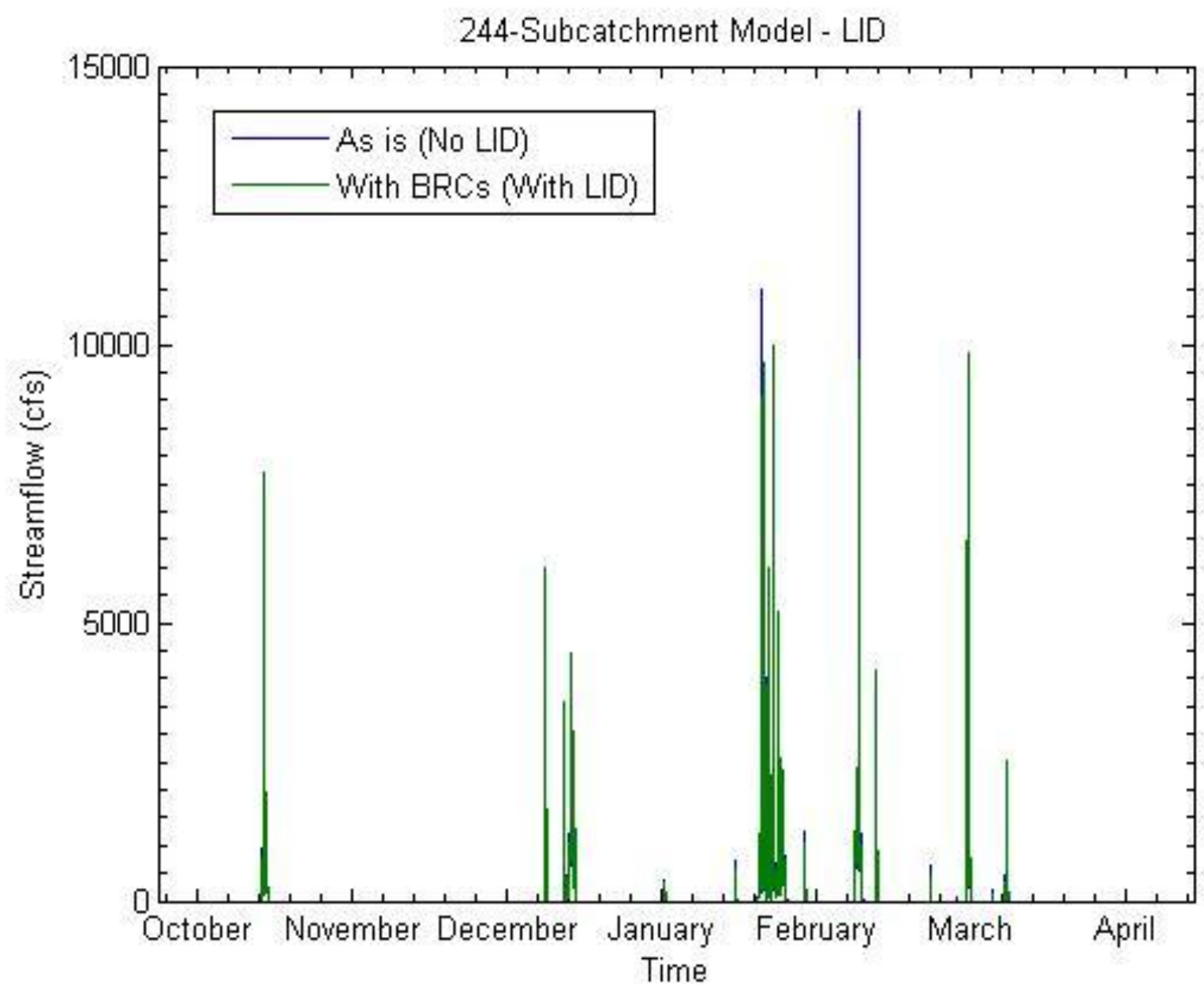

Figure 86: 244-Subcatchment model, with LID, calibration time series. 


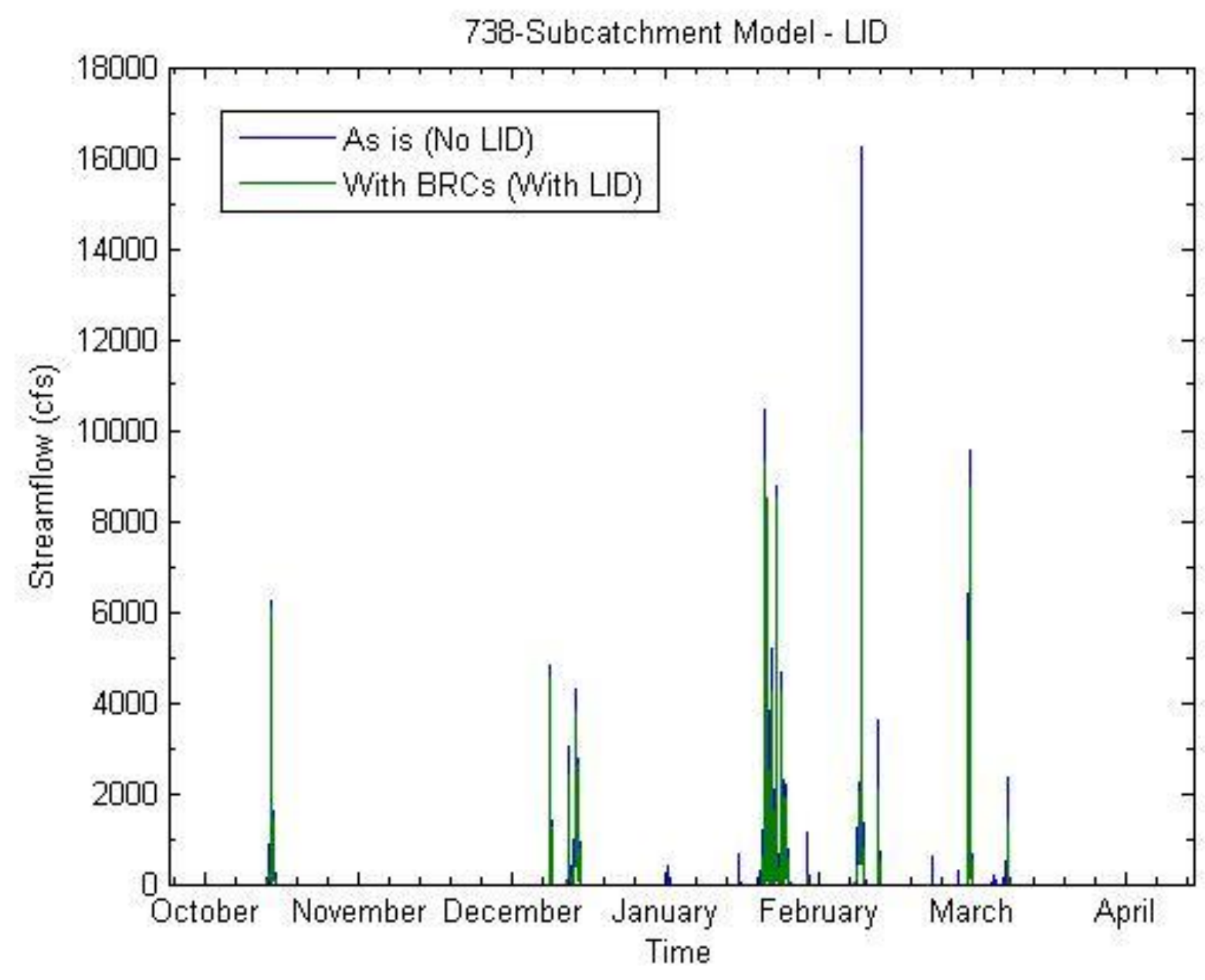

Figure 87: 738-Subcatchment model, with LID, calibration time series. 
1414-Subcatchment Model - LID

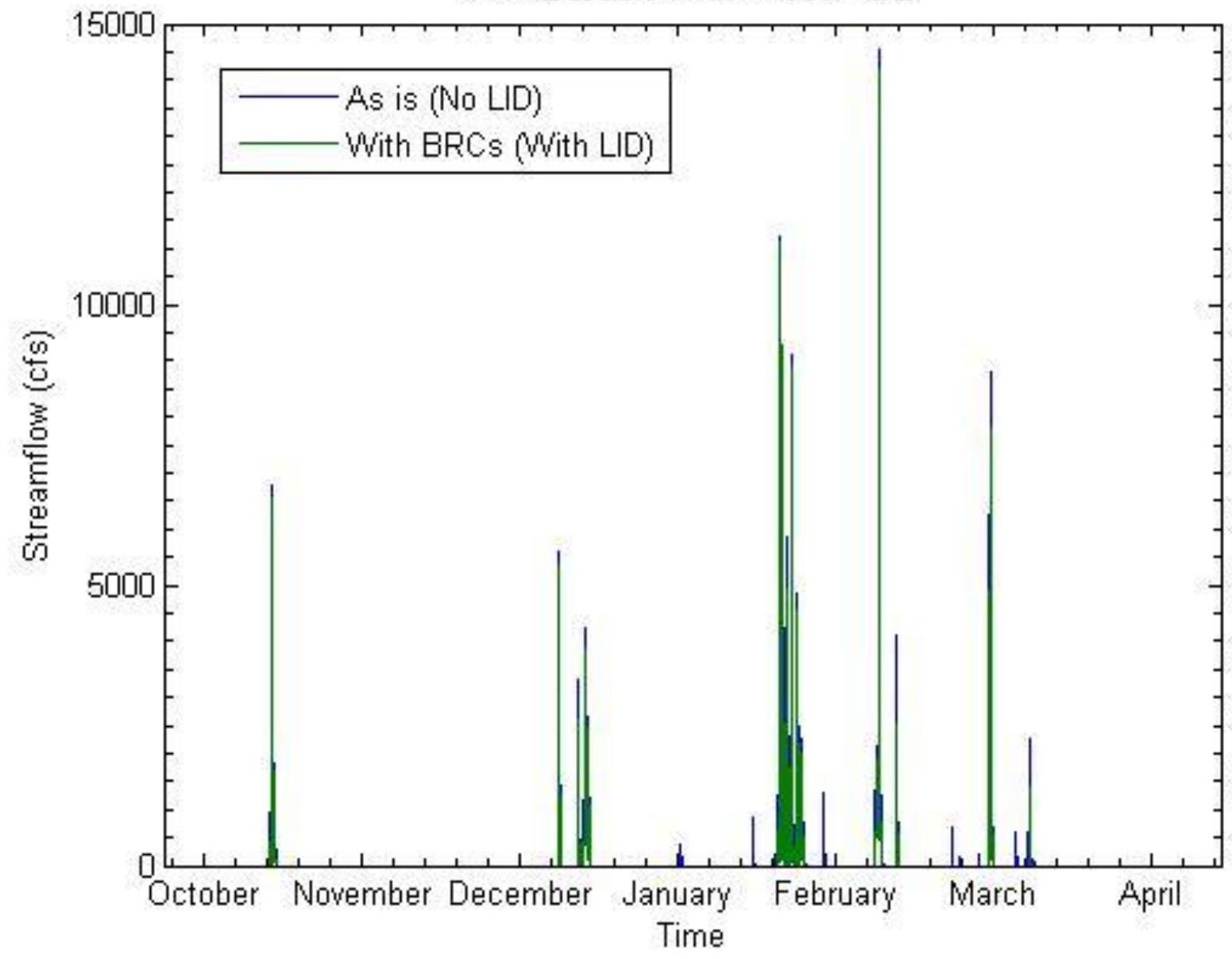

Figure 88: 1414-Subcatchment model, with LID, calibration time series 


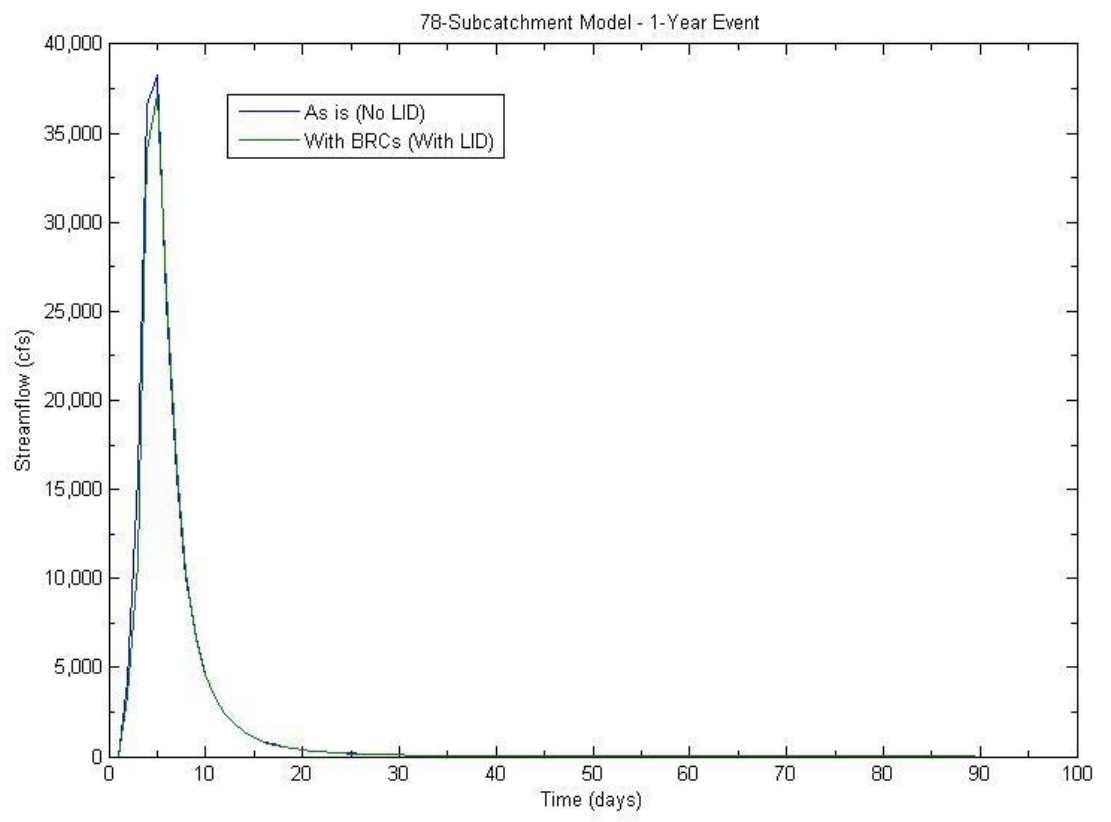

Figure 89: 78-Subcatchment model, 1-year storm hydrograph.

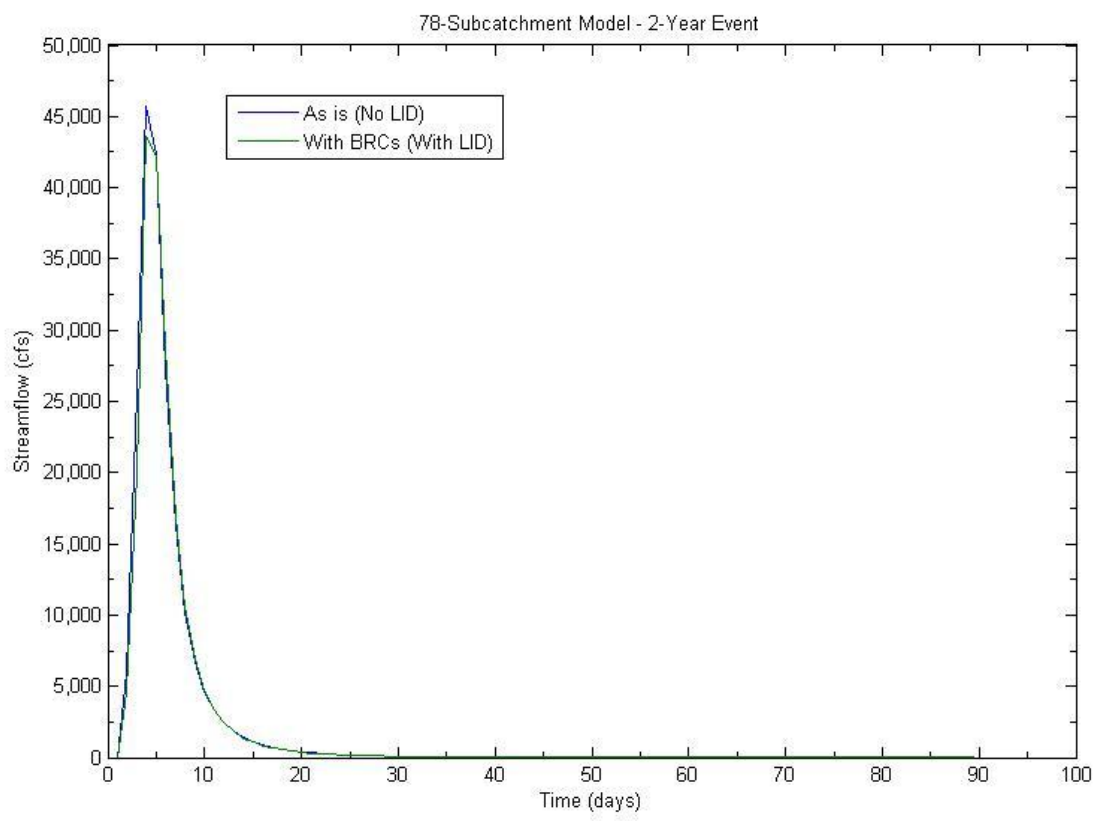

Figure 90: 78-subcatchment model, 2-year storm hydrograph. 


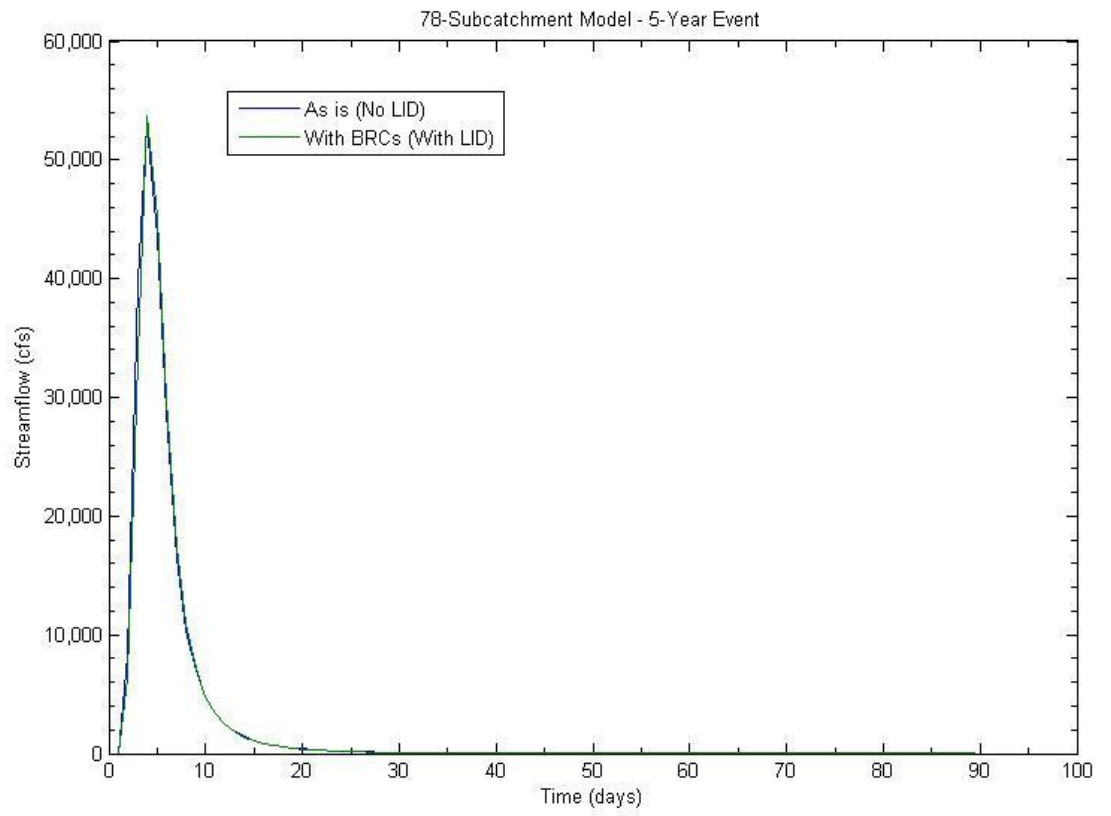

Figure 91: 78-Subcatchment model, 5-year storm hydrograph.

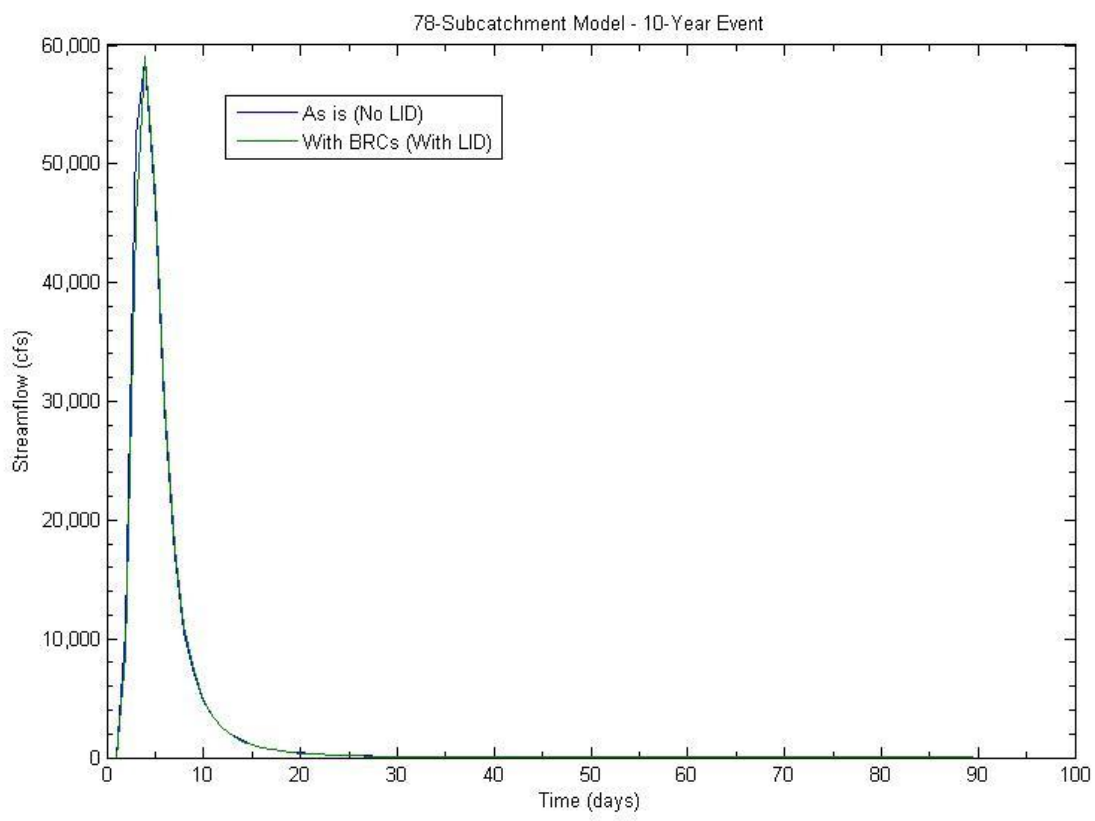

Figure 92: 78-Subcatchment model, 10-year storm hydrograph. 


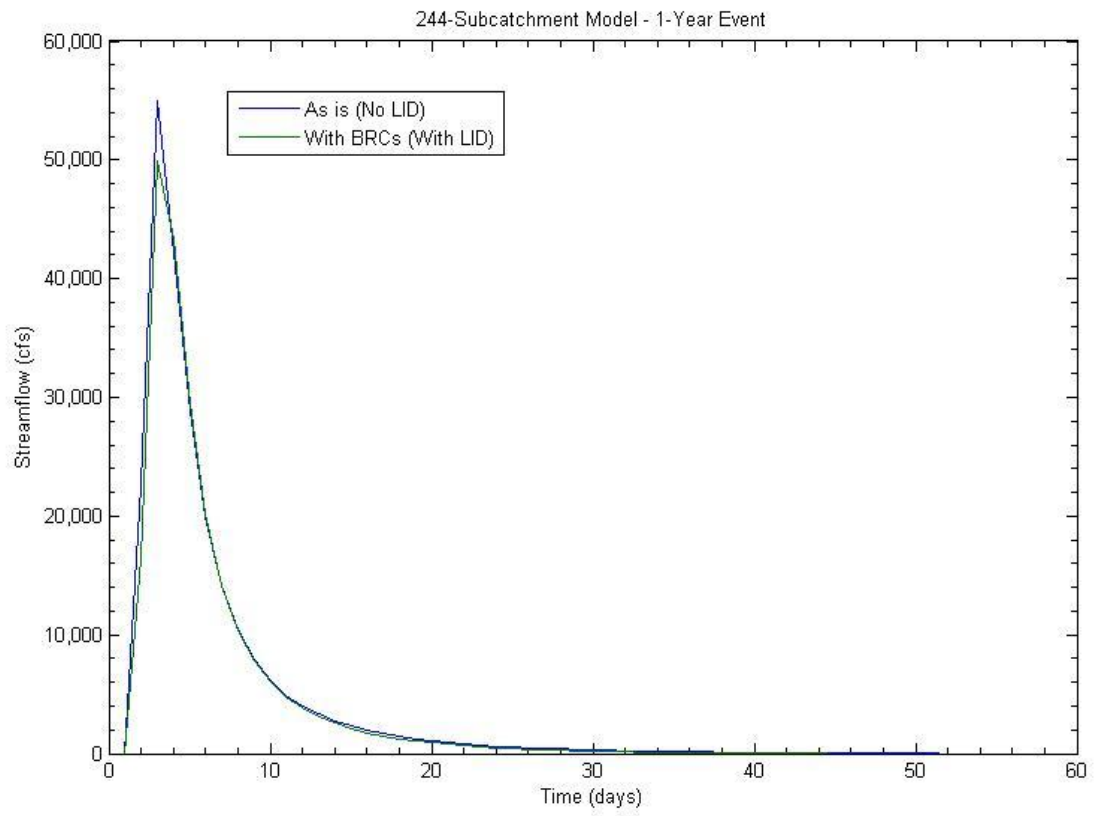

Figure 93: 244-subcatchment model, 1-year storm hydrograph.

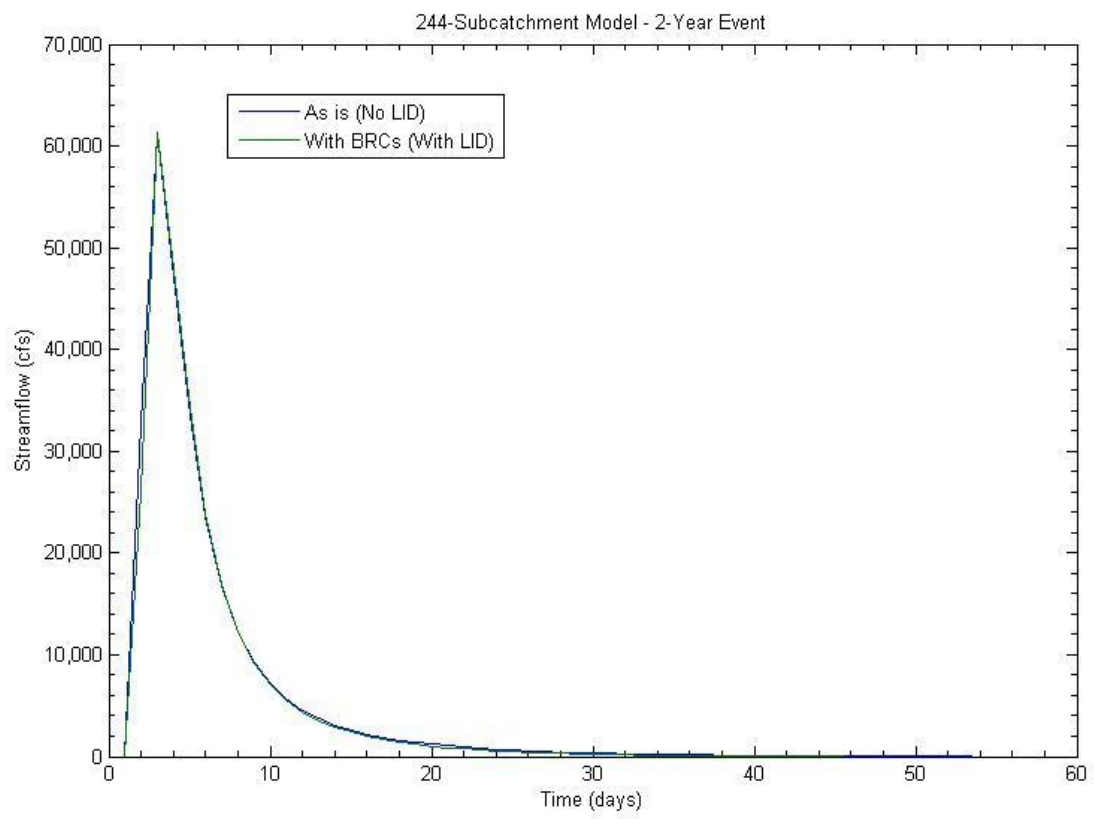

Figure 94: 244-subcatchment model, 2-year storm hydrograph. 


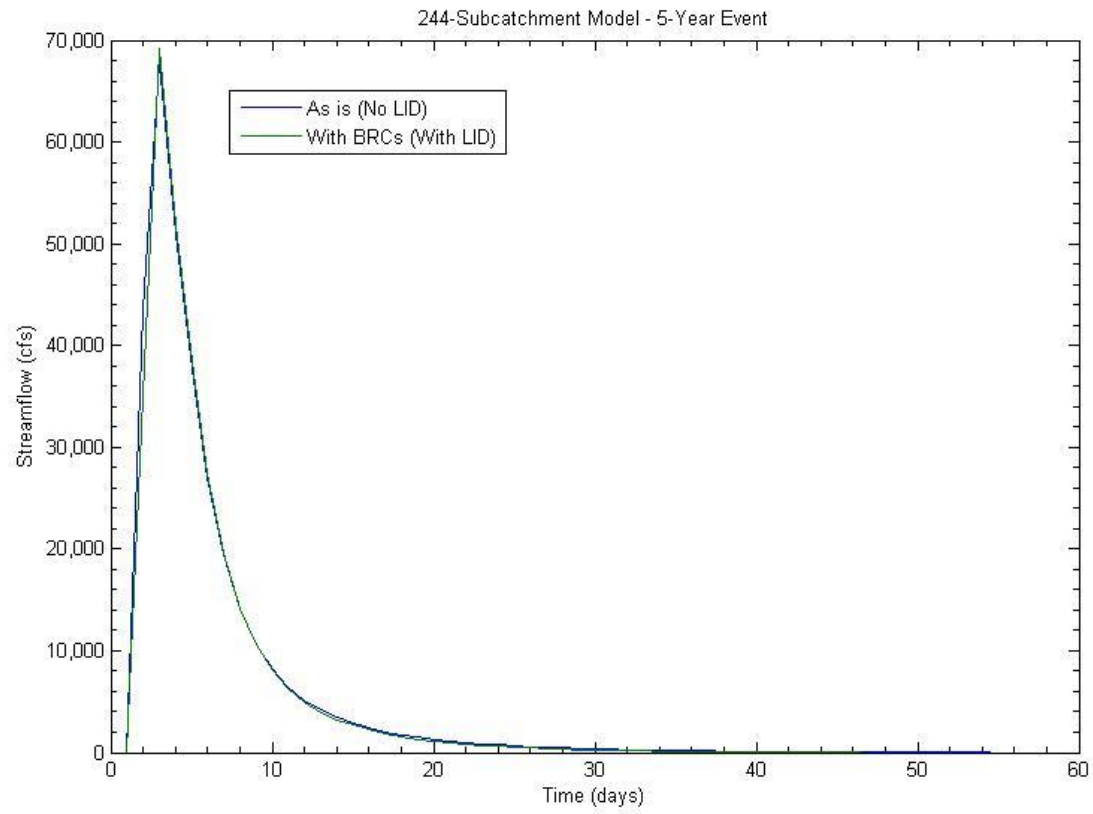

Figure 95: 244-subcatchment model, 5-year storm hydrograph.

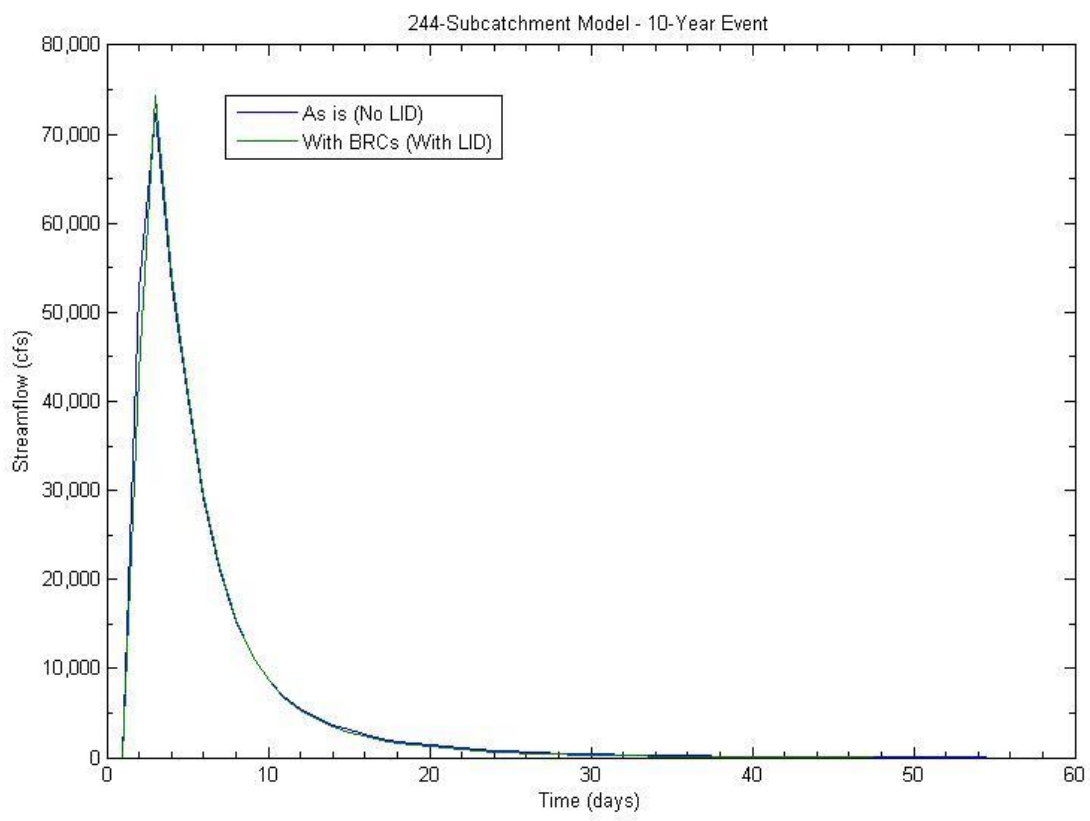

Figure 96: 244-subcatchment model, 10-year storm hydrograph. 


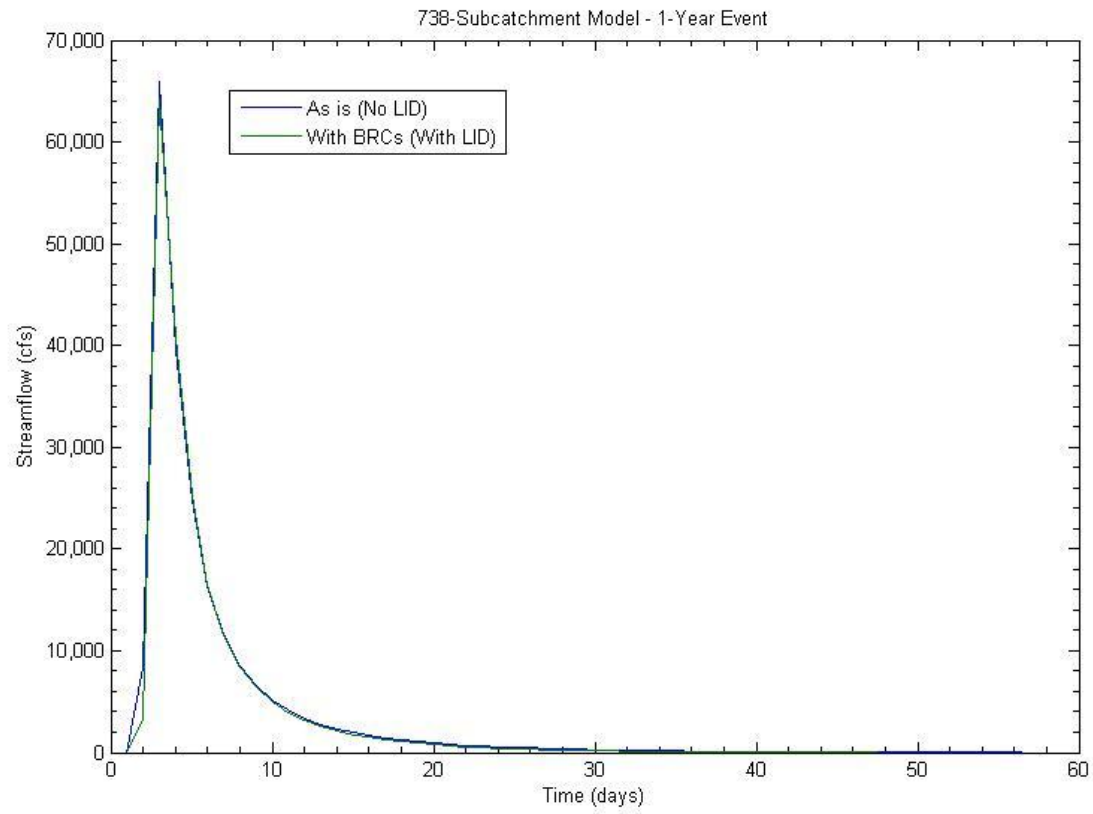

Figure 97: 738-subcatchment model, 1-year storm hydrograph.

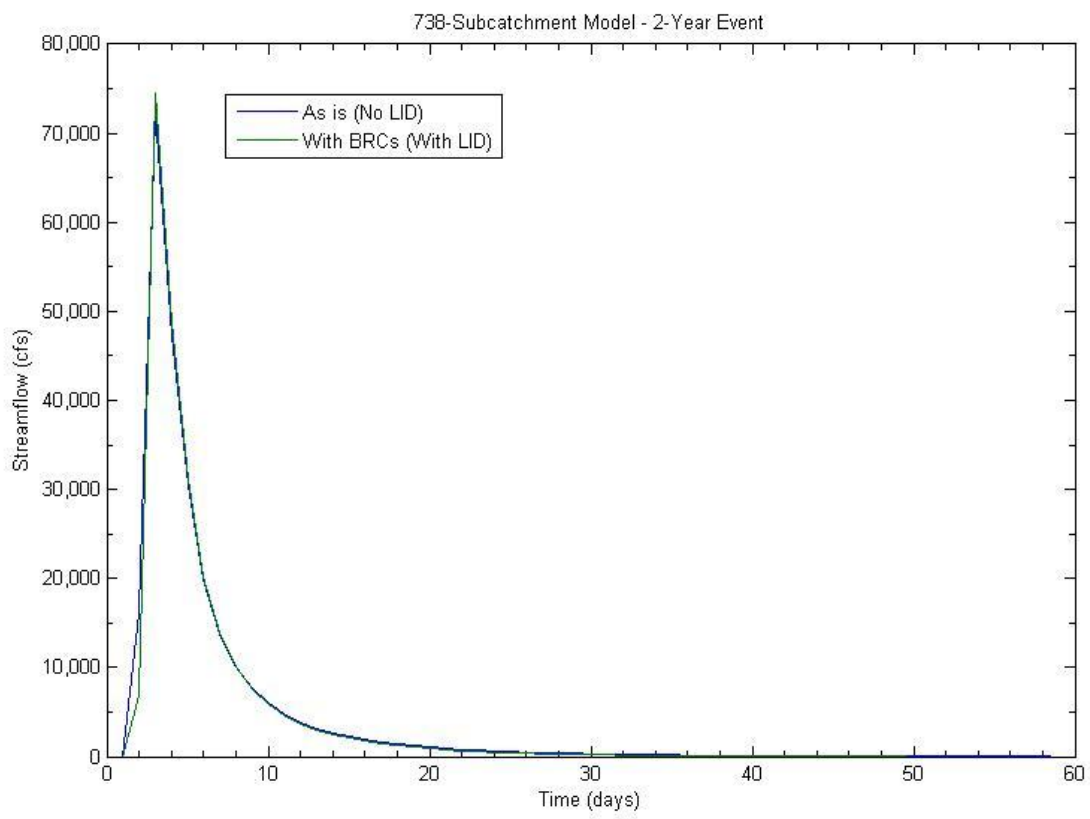

Figure 98: 738-subcatchment model, 2-year storm hydrograph. 


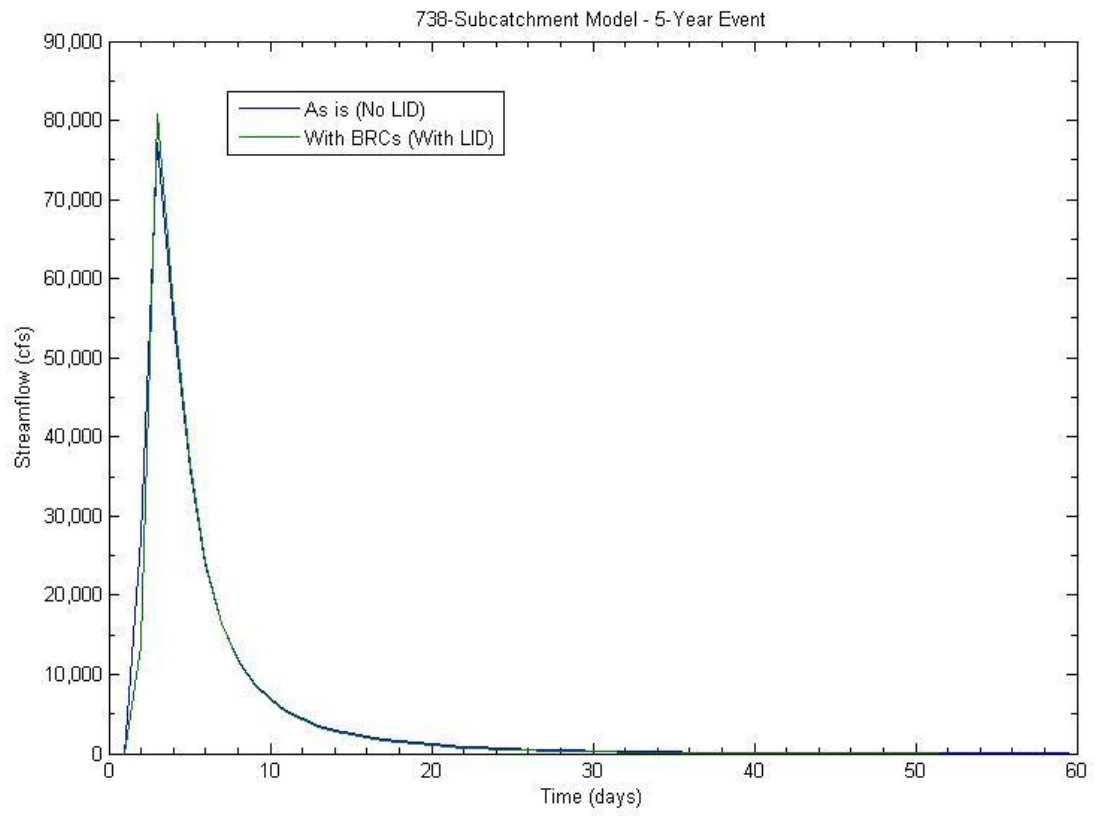

Figure 99: 738-subcatchment model, 5-year storm hydrograph.

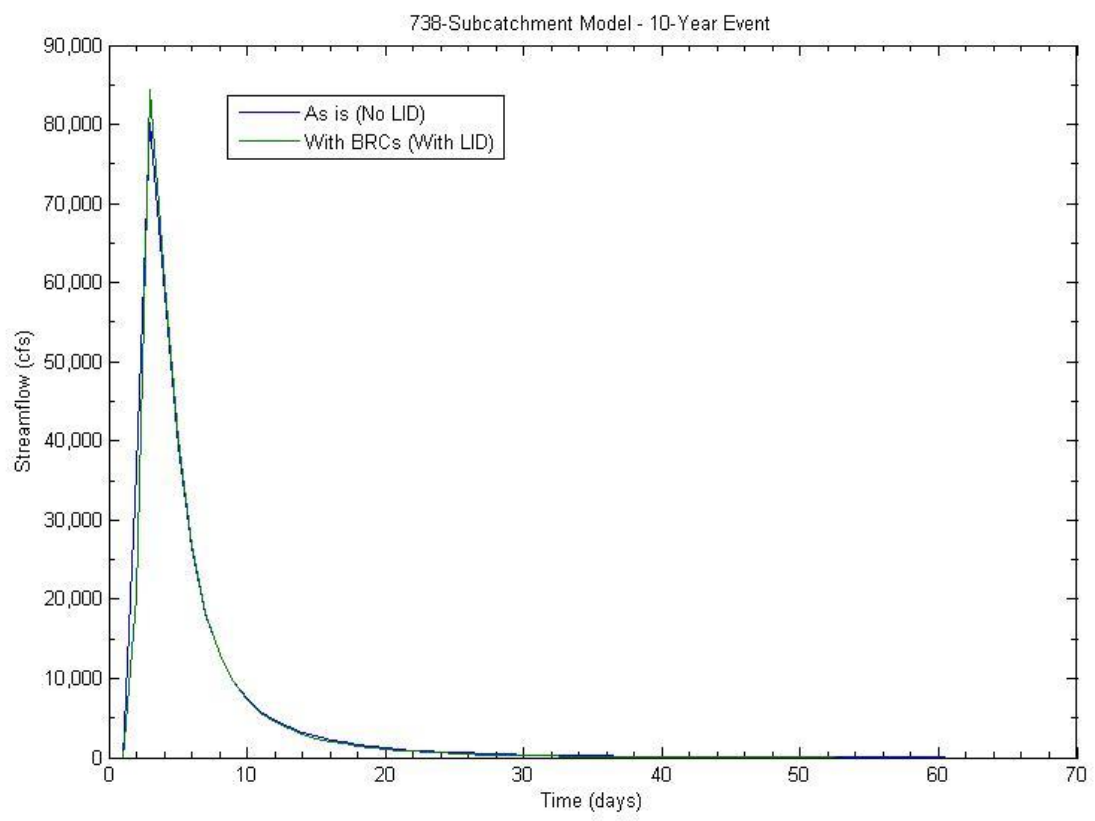

Figure 100: 738-subcatchment model, 10-year storm hydrograph. 


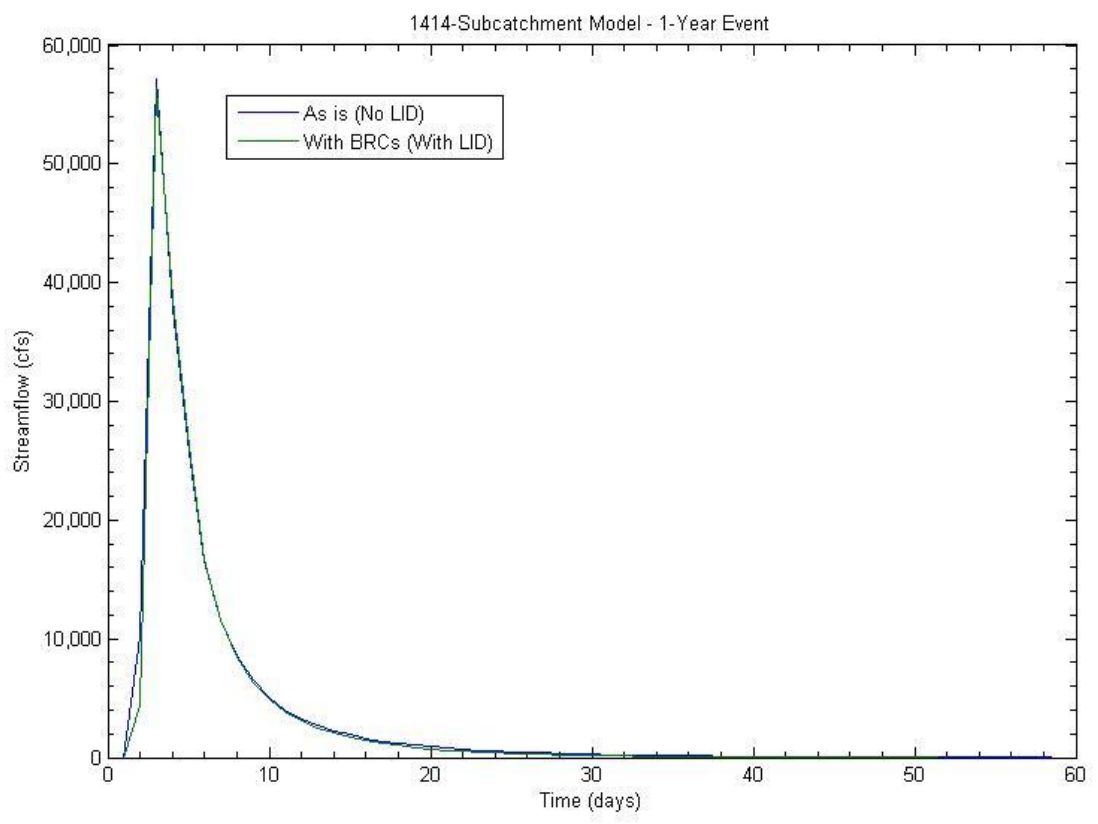

Figure 101: 1414-subcatchment model, 1-year storm hydrograph.

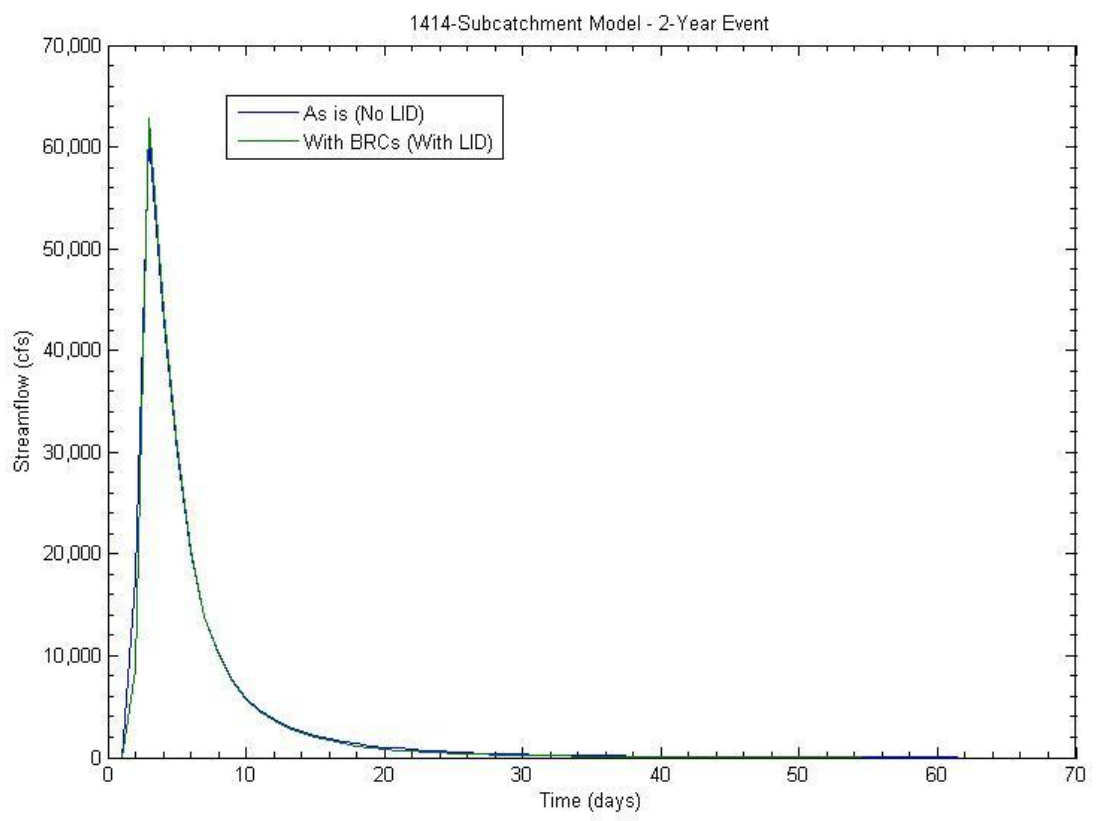

Figure 102: 1414-subcatchment model, 2-year storm hydrograph. 


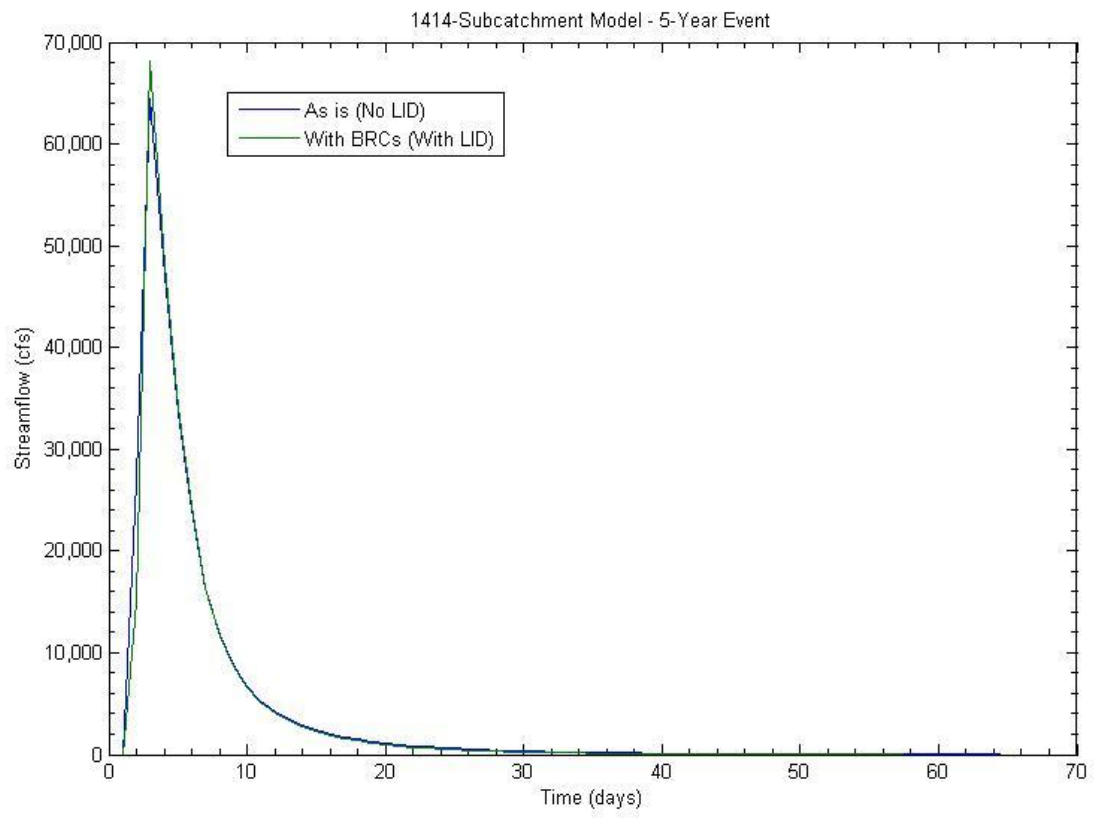

Figure 103: 1414-subcatchment model, 5-year storm hydrograph.

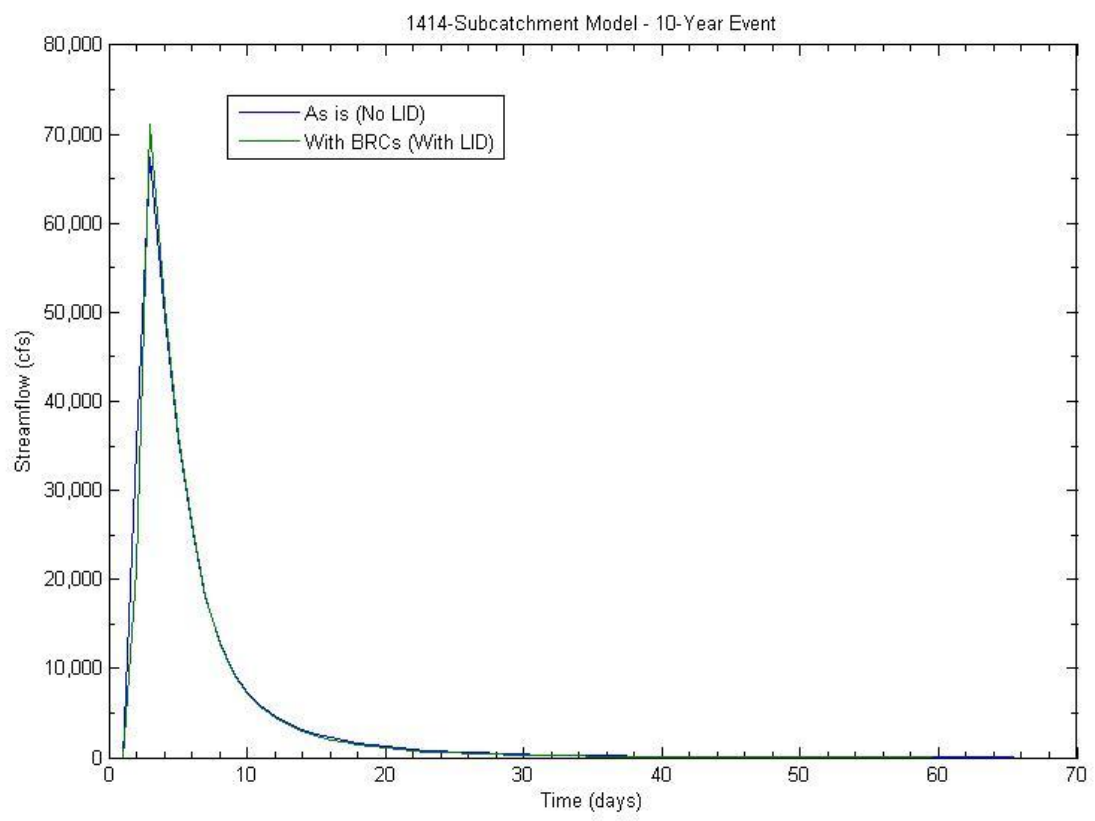

Figure 104: 1414-subcatchment model, 10-year storm hydrograph. 